ARQUIIETURA RELIGIOSA DE VILA BOA DE GOIÁS NO SÉCLLO XVIII

Prof. Dr. MÁRIO HENRIQUE SIMÃO d'AGOSIINO

orientador

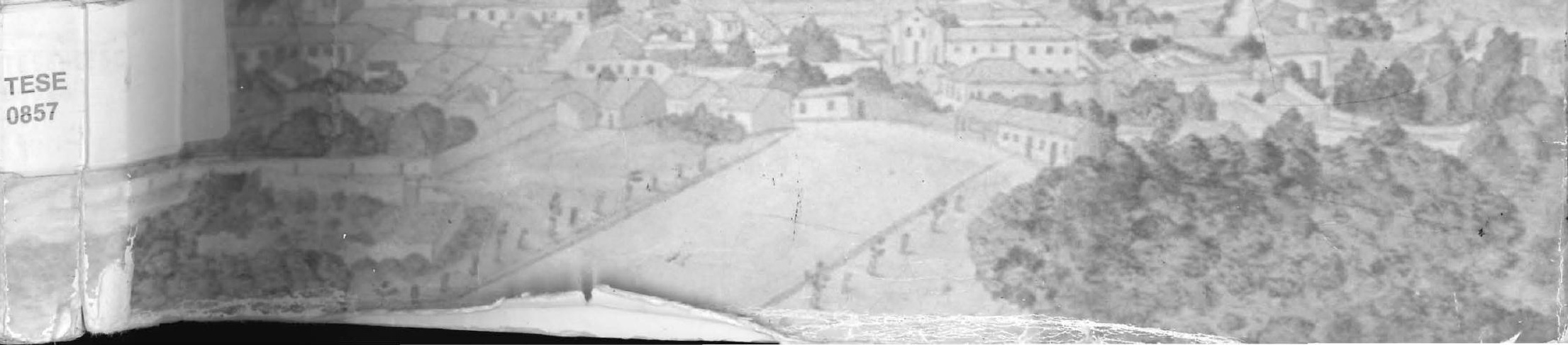


FOLHA DE JULGAMENTO

Candidata: Arquiteta DEUSA MARIA RODRIGUES BOAVENTURA

Dissertação defendida e julgada em 22-06-2001 perante a Comissão Julgadora:

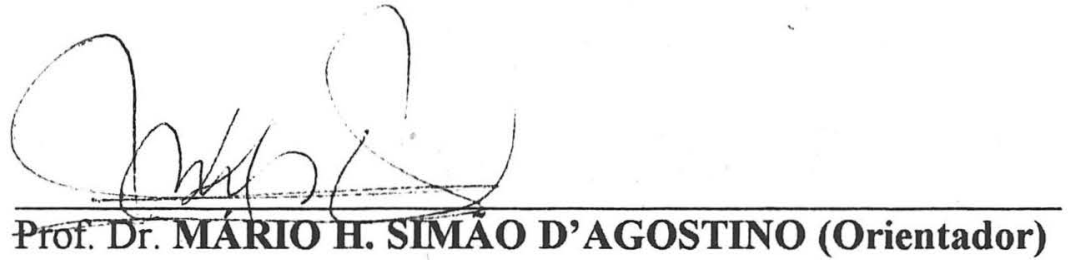

(Escola de Engenharia de São Carlos/USP)

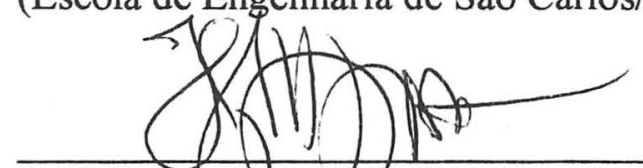

Prof. Dr. HUÇO MASSAKI SEGAWA

(Escola de Engenharia de São Carlos/USP)
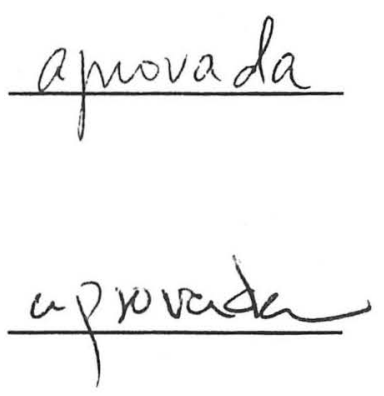

Aprovada

Profa. Dra. MARÍLIA MARIA B. TEIXEIRA VALE (Universidade Federal de Uberlândia - UFU)

lacles de Ardach.

Prof. Doutor CARLOS ROBERTO M. DE ANDRADE Coordenador do Programa de Pós-Graduação em Arquitetura

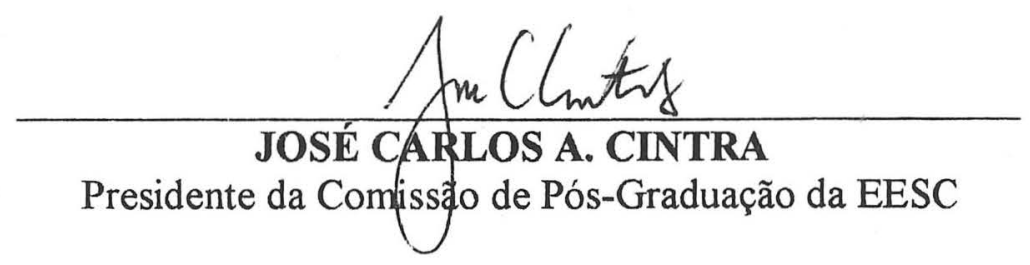




\section{ARQUITETURA RELIGIOSA DE VILA BOA DE GOIÁS NO SÉCULO XVIII}


Serviço de Pós-Gradução EESC/USP

EXEMPLAR REVISADO

Data de entrada no Serviço:......................... Ass.........................................

\section{ARQUITETURA RELIGIOSA DE VILA BOA DE GOIÁS NO SÉCULO XVIII}

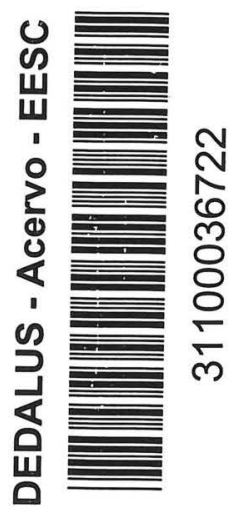

Dissertação apresentada ao Programa de Pós-Graduação em Arquitetura e Urbanismo da Escola de Engenharia de São Carlos da Universidade de São Paulo para a obtenção do grau de Mestre em Arquitetura e URBANISMO.

Orientador:

Prof. Dr. Mário Henrique Simāo D’Agostino

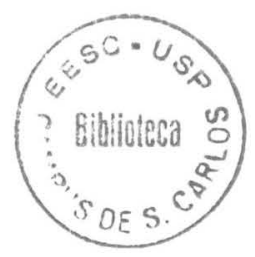




\section{AgradeCimentos}

Muitos foram aqueles que contribuíram para que esta dissertaçáo pudesse ser realizada e é com satisfação que agradeço os auxílios e sugestôes que me foram prestados. Assim, os meus sinceros agradecimentos:

ao meu orientador, professor Mário Henrique Simão D’Agostino, a quem dirijo o meu respeito e reconhecimento e com quem compartilho este trabalho, pelas incansáveis discussóes, apoio e estímulo à pesquisa - um grande intelectual e mestre entusiasta que me soube guiar e apontar-me soluçóes que pareciam impossíveis;

ao professor Dr. Rafael Moreira, que gentilmente acolheu-me na Universidade Nova de Lisboa, sugerindo e indicando caminhos que me foram úteis e jamais esquecidos;

à banca examinadora, professora Marília Maria Brasileiro Vale e professor Hugo Segawa, que me apontaram sugestóes indispensáveis desde o exame de qualificação;

ao programa de Mestrado em Arquitetura e Urbanismo da USP/São Carlos, que bem me recebeu com seus professores e funcionários;

à professora Cibele Saliba Rizek, que me aconselhou e me ajudou a tomar decisóes fundamentais no início do curso;

ao professor Paulo Bertran, cujas entrevistas me enriqueceram;

aos companheiros de Departamento da Universidade Católica de Goiás, professores Dirceu Lima Trindade, Gustavo Neiva Coelho e Maria Heloisa Veloso e Zárate, pela oferta de seus trabalhos, livros, sugestốes e discussóes que contribuíram para o andamento da pesquisa;

ao Laerte, grande amigo e responsável pelo projeto gráfico da dissertação;

à professora historiadora Cristina de Cássia, da Universidade Federal de Goiás, que me auxiliou na indicação de arquivos, em Portugal e em Goiás, cedendo-me documentos de inestimável valor;

aos professores Luis Cláudio Bitencourt, Beatriz P. Bueno da PUC de Campinas, e Selma Miranda, de Belo Horizonte, pelo empréstimo de livros e indicaçóes de arquivos; aos professores Italiano Monini, da UCG, e Ildeu Coelho, da UFG, co-responsáveis pela minha decisão de fazer o mestrado;

aos colegas de mestrado, Maria Eliana Jubé (Lana), amiga e companheira de jornada de trabalho; Adriana Irigoyen; Rodrigo de Jesus e Stela Toledo; e uma atençáo especial ao amigo Guilherme Mazzda Dourado, que me enviou, sempre que necessário, livros das bibliotecas de São Paulo. 
Também não quero deixar de lembrar todos os funcionários das instituiçóes onde fiz consultas, aqui representados pelo Antônio César Caldas Pinheiro, do Arquivo do Centro de Pesquisa Histórica Dom Fernando. Em Portugal: Arquivo Histórico Ultramarino, Arquivo Nacional Torre do Tombo e Biblioteca Nacional de Lisboa. No Brasil: Arquivo Histórico de Goiânia, Arquivo do Instituto D. Fernando, Instituto Histórico e Geográfico de Goiás, Museu Frei Simão Dorvi da cidade de Goiás, Arquivo Nacional, Biblioteca Nacional e Biblioteca Mário de Andrade.

E, muito importante, os meus mais profundos e ternos agradecimentos ao meu companheiro de vida, Alberto R. Boaventura, è̀s minhas duas filhas, Lorena e Carolina, que sempre apostaram em mim, não me deixando desanimar perante as dificuldades e os percalços encontrados ao longo desses três anos.

\section{Três dedicatórias especiais}

Educador é quem ensina, orienta, aconselha e é amigo; ao Maique, meu grande professor.

Aos meus pais, pela minha existência.

Ao Alberto, Lorena e Carolina, pela razão do meu viver. 


\section{SUMÁRIO}

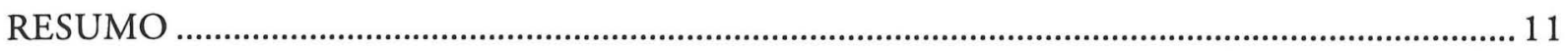

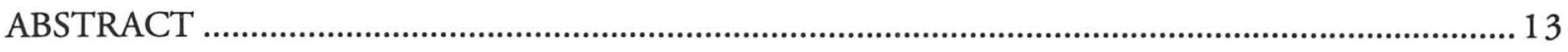

INTRODUÇÃO

GOIÁS: ENTRE O BARROCO E O MODERNO …………………………………........ 15

A ARQUITETURA DE GOIÁS E A HISTORIOGRAFIA REGIONAL .............................19

CAPÍTULO 1

A IGREJA E A CIDADE ……………….................................................................................29

1.1 O URBANISMO PORTUGUÊS E A FORMAÇÃO DE VILA BOA DE GOIÁS .......33

1.2 O ARRAIAL DE SANTANA E A IGREJA ………………………………………....... 37

1.3 UMA NOVA CONCEPÇÃO ESPACIAL: VILA BOA DE GOIÁS ................................42

1.4 AS REFORMAS URBANAS NA SEGUNDA METADE DO SÉCULO XVIII .............47

1.5 IGREJAS E LARGOS: PERMANÊNCIAS E RUPTURAS ..........................................50

CAPÍTULO 2

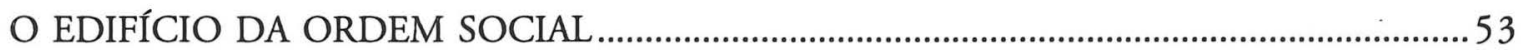

2.1 A ADMINISTRAÇÃO ECLESIÁSTICA EM GOIÁS ...................................................55

2.2 OS CONDICIONANTES SOCIAIS E INSTITUCIONAIS ………………………....58

2.3 OS ESPAÇOS RELIGIOSOS E A CIDADE ………….............................................62

CAPÍTULO 3

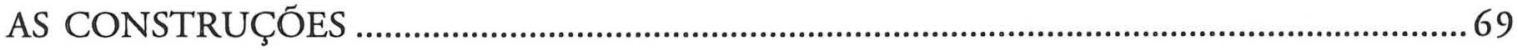

3.1 OS ARTESÃOS DE VILA BOA ……………………..........................................

3.2 O CONTROLE DAS CONSTRUÇÓES ....................................................................74

3.3. A EDIFICAÇÃO E A CONCEPÇÃO DAS IGREJAS ...................................................78 
CAPÍTULO 4

A ARQUITETURA DAS IGREJAS: REFERÊNCIAS TIPOLÓGICAS .........................93

4.1 A ARQUITETURA PORTUGUESA E VILA BOA ………………………………......96

4.2 IGREJAS BASILICAIS E DE NAVE ÚNICA: A DEFINIÇÃO DOS TIPOS .................98

4.3 AS IGREJAS DE PLANOS CENTRALIZADOS: OS TIPOS OCTOGONAIS..........107

4.3.1 ANTECEDENTES

$\ldots .107$

4.3.2 A DIFUSÃO DOS TIPOS OCTOGONAIS NO BARROCO ……………….....109

CONCLUSÃO

BIBLIOGRAFIA

FONTES DOCUMENTAIS

LISTA DE FIGURAS
RESUMO

O estudo das igrejas setecentistas de Vila Boa de Goiás liga-se à história de sua formação urbana, em particular a três de seus momentos - o Arraial de Santana, a fundação da Vila e as intervençōes de José de Almeida e Luís da Cunha Menezes. Cada um desses momentos foi marcado por diferentes práticas urbanísticas, desenvolvidas no contexto das experiências da Expansão Ultramarina, que cedeu ao edifício religioso uma posição relevante na organização do espaço urbano. Nesse contexto, tanto a construção das igrejas como o seu processo construtivo foram regulados por um complexo jogo social, relacionado a práticas de caráter hierárquico e segregacionista. Nele, os grupos de profissionais, em diferentes momentos, atuaram por arremataçáo de serviços, implicando notórias descontinuidades estilísticas, só atenuadas pelo respeito que manifestaram pela ordem espacial litúrgica, que repetiu a mesma lógica e hierarquia sociais. O vínculo com o contexto da Expansão Ultramarina ainda dialogou com a Metrópole e capitanias adjacentes, onde se encontram tipos retangulares e octogonais, característicos do quadro da arquitetura religiosa de Vila Boa de Goiás. 


\section{ABSTRACT}

The study of the churches built during the 1700's in Vila Boa de Goiás is connected to the history of its own urban formation, and it is related to the three of its moments - Arraial de Santana, the foundation of the Vila and the interventions, which came from José de Almeida and Luís da Cunha Menezes. Each one of those moments was market by different urbanistc practices, developed in the context of the experiences, in turn; they came from the Ultramarine Expansion that gave to the religious building an important position in the organization of the urban space. In that context, as much the construction of the churches as its constructive process they were regulated by a complex social game, related to practices of hierarchical character and segregationist. In that process, the professionals' groups, in different moments, had service auctions, which implied well-known stylistic discontinuity, only lessened by the respected that they manifested for the liturgical space order, which repeted the same logic and social hierarchy. The link with the context from the Ultramarine Expansion was still related to the Metropolis and adjacent captaincies, where the constructions are rectangular 


\section{N T R O D U ÇÃ O}

GOIÁS: ENTRE O

BARROCO E O MODERNO 

mbora o barroco brasileiro venha sendo um tema estudado e discutido nos últimos decênios, a arquitetura setecentista da antiga Capitania de Goiás tem sido objeto de pouca atenção da historiografia artística brasileira. ${ }^{1}$ Essa questão, ao que parece, pode estar associada à idéia de marginalidade e decadência da região, que se desenvolveu, desde o século passado, com as visitas feitas a Goiás por viajantes estrangeiros, como Aires de Casal, Auguste de Saint-Hilaire, D’Alincourt, Johann Emmanuel Pohl, Raymundo José da Cunha Mattos, Burchell, Gardner, Castenau, Spix e Martius. ${ }^{2}$

Esses viajantes, ao deixarem testemunhos sob a forma de diários, memórias, guias de viagem ou relatórios, avaliaram pejorativamente não só Vila Boa de Goiás como também outras cidades coloniais brasileiras, sempre guardando distância para informar sobre uma realidade de que nunca se sentiram fazendo parte.

No entanto, "não se abstiveram de as descrever tomando como modelo comparativo as suas cidades de origem ou residência (...). Foi por isso que o contato com muitos desses aglomerados em solo tropical deixou impressóes nem sempre aprazíveis. Sentiam falta do conforto, dos equipamentos sofisticados das suas cidades, da ópera, do teatro, cuja produção local consideravam medíocre, escandalizando-se com a falta de higiene e salubridade que ameaçavam a saúde das comunidades urbanas" . ${ }^{3}$

Em Goiás, os olhares viajantes que prevaleceram e se fixaram no nosso imaginário não foram os que exaltaram os aspectos pitorescos da província, mas os que testemunharam as impressóes negativas sobre a cidade de Vila Boa, como relatou Auguste de Saint-Hilaire:

1 No artigo "Da terra: madeira e barro como suporte para a cor e o ouro", Aracy Amaral chama a atenção para a importância do estudo da arquitetura de pequenas igrejas, incluindo a capela goiana Nossa Senhora da Abadia: "Talvez por que lhes falte a escala do "maior"? Porque mais interessados pelos momentos do apogeu, correspondem a um período arcaico de nosso passado artístico, miscigenado por natureza?" AMARAL, Aracy. "Da terra: madeira e barro como suporte para a cor e o ouro". In: Revista Barroco. Belo Horizonte: SPHAN/ UFOP, n. 12, 1982/3. p. 281.

2 Aires de Casal é considerado o primeiro viajante a fazer um relato sobre Goiás, em 1817. Leite Moraes e Oscar Leal também foram cronistas que passaram por Goiás, embora não estrangeiros.

3 MILHEIRO, Ana Cristina Fernandes Vaz. "Um olhar intruso: o mundo urbano brasileiro narrado através da sensibilidade do estrangeiro". VI Seminário de história da cidade e do urbanismo. Natal, 24/27 de out. de 2000. 
(...) construída numa baixada, onde o ar não circula como nas montanhas e nas planícies; onde a água parece pouco salubre e o calor é quase sempre sufocante durante a seca; onde, enfim, a umidade deve ser muito grande na estação das chuvas, essa cidade, repito, não pode ser própria aos homens de nossa raça. ${ }^{4}$

Associados às descrições da cidade, Nars Fayad Chaul ${ }^{5}$ diz encontrar também os comentários de Pohl e D'Alincourt sobre a precariedade das estradas e acessos a Goiás, que colocaram a capitania, a partir do século XIX, numa situação de total isolamento em relação aos trajetos comerciais e as áreas mais desenvolvidas do Brasil. Esses fatos ajudaram a justificar a penúria e o estado de atraso e solidão em que se encontrava a região. E foi nesse contexto de pobreza e decadência que a arquitetura de Vila Boa foi identificada por Saint - Hilaire como medíocre, pequena, sem beleza, mesquinha e sem solidez. $^{6}$

Assim, esses olhares dos viajantes oitocentistas deixaram como herança para o Estado o estigma do retrocesso, do ócio e do isolamento que, provavelmente, contribuíram para o descaso com a sua historiografia artística, negando-se os pesquisadores, em sua grande maioria, a estudar o seu patrimônio em seus diferentes aspectos, esquecendo-se da arte que se produziu na regiáo, como atestam os poucos estudos que foram realizados sobre a arquitetura setecentista de Vila Boa.

Atualmente, estudiosos como Nasr Fayad Chaul vêm trazendo à investigaçáo novas leituras e análises que problematizam os equívocos formados ao longo do século XIX e meados do XX, e que marcaram a região com traços de pobreza. Segundo ele, com o paradigma da decadência se confundem crescimento econômico e desenvolvimento social. Dessa forma, o declínio do ciclo do ouro ficou estigmatizado por uma visão que possui suas raízes na idéia de atraso:

Em torno da imagem da decadência, vai girar todo o universo interpretativo acerca da sociedade goiana que transitou da mineraçâo para a agropecuária. A partir da idéia de um pretenso desenvolvimento da sociedade mineradora, criou-se o posterior espectro de decadência que passa a rondar e sociedade após a mineração.

O trabalho de Chaul abre outras possibilidades interpretativas para a arquitetura local, permitindo entendê-la a partir de uma perspectiva que, além de desconsiderar conceitos atrelados à idéia de decadência, também desconsidera aqueles tradicionalmente consolidados no âmbito da historiografi brasileira e mais diretamente comprometidos como os princípios do modernismo. Para melhor defi-

4 Saint-Hilaire, Auguste de. Viagem à provincia de Goiás. Belo Horizonte: Itatiaia; São Paulo: USP, 1975. p. 51 "Por isso, a ausência de estradas, ou as péssimas condiçōes, faziam parte de todos os discursos e clamores da época, desde o viajantes ate os historiadores contemporâneos que analisaram a Província de Goiás". CHAUL, Nasr Fayad. Caminhos de Goiats.

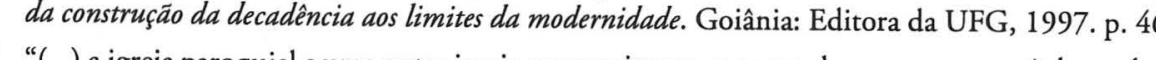

"(...) a igreja paroquial e uma outra igreja menor situam-se numa dessas praças que é chamada de terreiro do passo. A outra, que . mas pelo menos não é grotesca”. Saint-Hilaire, Auguste de. Op. cit.

"Quando falo de prédios públicos năo se deve imaginar que se trata dos enormes edifícios que se vêem na Europa. Ali tudo CHAUL Nas mesquinho, sem beleza e até mesmo, segundo dizem, sem solidez". Idem. p. 51.

CHAUL, Nasr Fayad. Op. Cit. p. 16 nir essas possibilidades, convém colocar em tela esses dois valores com os quais o estudo da arquitetura local se estabeleceu no passado.

\section{A ARQUITETURA DE GOIÁS E A HISTORIOGRAFIA REGIONAL}

No quadro da literatura artística de Goiás, os autores Eduardo Etzel, Luis Palacin, Paulo Bertran e Gustavo Coelho foram os que mais publicaram sobre a arquitetura e urbanismo coloniais, e esse reduzido número de autores e publicaçôes não forma um conjunto historiográfico homogêneo: ora apresenta vínculos com o conceito de decadência, como Palacin e Bertran, ${ }^{8}$ ora se aproxima de Sylvio de Vasconcellos e Paulo Santos, compartilhando formulaçóes teóricas provenientes da arquitetura moderna, como Eduardo Etzel e Gustavo Coelho

Examinar, portanto, as leituras que se aproximam da visão dos viajantes do século passado, bem como as concepções teóricas de Sylvio de Vasconcellos e Paulo Santos, constitui um importante passo para a compreensão da historiografia de Goiás, na medida em que foram importantes marcos de referência para os autores locais.

A interpretação a que se vinculam esses dois autores iniciou-se com a revalorização da arte colonial a partir da década de 20, impulsionada por intelectuais e artistas do chamado "movimento modernista", liderados por Mário de Andrade e Lúcio Costa. Ao primeiro, deve-se a responsabilidade da conceituaçáo do tema da "originalidade nacional" e, a Lúcio Costa, um tipo de leitura interpretativa baseada na idéia de "espírito de época" e "evolução artística", que marcou significativamente a historiografia tradicional e transformou-se em um dos maiores eixos epistemológicos de várias obras da literatura artística nacional. Correlata a essas leituras, e concomitante a elas, encontra-se também a que busca explicar as formas artísticas segundo os condicionantes tecnológicos e geográficos das diferentes regióes do país, e cujos importantes representantes nacionais são Sylvio de Vasconcellos e Carlos Lemos.

A leitura da História da Arte que se fundamenta numa idéia evolucionista dos objetos artísticos recupera uma historiografia de procedência hegeliana, ${ }^{9}$ que se orienta pelos grandes períodos da história universal, suas mudanças, evoluçōes e exaltação de valores nacionais. Segundo essas consideraçóes, a forma artística é reconhecida como o resultado de um conhecimento deduzido de um sistema maior, no qual se encontram todos os aspectos de uma cultura. Diferentemente, mas bastante correlacionada à visão da cultura como totalidade, as interpretaçôes que adotam os aspectos tecnológicos e geográficos como condicionantes da forma arquitetônica encontram-se sob a influência, desde a segunda metade do século passado, de uma das maiores referências teóricas da historiografia artística:

8 "Esta geraçăo de historiadores, que procurou analisar a história da Província de Goiás, manteve a tese da decadência, embora já se note uma diversificaąăo nas razōes explicativas do fenômeno. Alguns colocam ênfase nos aspectos econômicos, outros na política e administraçáa da época, muitos na formaçáo do povo, na questăo da raça, destacando aspectos levantados pelos viajantes, como o ócio, o marasmo e a preguiça. Em todos eles, a idéia fixa da decadência permaneceu como um marco
inquestionável até os anos 90 . Dessa safra, destaca-se Paulo Bertran que, jáem fins dos anos 70 , relativiza a questäo (...)." Idem. p. 64

"A história do mundo representa [...] a evoluçăo do reconhecimento por parte do espírito da sua própria liberdade [...]. Cada passo, por ser diferente de qualquer outro, tem seu próprio princípio determinado e peculiar. Na história., tal princípio se converte na determinaçáo do espírito, um particular espírito nacional. Eis aqui onde expressa concretamente todos os aspectos 2 de sua conscinciac 
Gottfried Semper, historiador vienense e representante máximo da concepção positivista da História da Arte, como diz Sòla Morales:

No caso de Semper, arquiteto não só teórico mas grande construtor na Europa Central, havia que buscar a explicação dos tipos essenciais das formas artísticas nas técnicas produtivas que as tinhm configurado na sua origem e evoluçāo (...). As formas têxteis ou cerâmicas mais elementares estariam na origem das formas mais artísticas mais complexas, e estas teriam sua origem não diretamente na mimese da realidade, senáo nas possibilidades oferecidas pelo tipo de urdidura utilizada ou pelo uso do torno e da incisão mais simples e econômicas..$^{10}$

A grande maioria dos textos publicados sobre o Barroco no Brasil situa-se, comumente, junçáo dessas duas correntes, ${ }^{11}$ podendo-se afirmar que elas foram os parâmetros mais recorrentes nos estudos de história da arquitetura brasileira.

Segundo Marcelo Puppi, ${ }^{12}$ as obras de Lúcio Costa foram as precursoras desse tipo amalgamado de abordagem, encontrando-se, nas suas várias publicaçōes, que não estão reunidas em um único volume, diga-se de passagem, mas em vários escritos, a interpretação da arquitetura brasileira a partir das condiçóes do meio, com as destacadas dificuldades materiais de toda ordem, desde a falta de mão de obra até as enormes distâncias. Com Lúcio Costa, consolidaram-se efetivamente as análises a partir dos supostos modernistas dos condicionantes históricos ou tecnológicos, visando particularmente a alcançar o entendimento sobre a forma e a genealogia dos estilos:

Quando se estuda qualquer obra de arquitetura, importa ter primeiro em vista, além das imposiçôes do meio físico, e social, consideradas no seu sentido mais amplo, o "programa", isto é, quị finalidades dela e as necessidades de natureza funcional a satisfazer; em seguida " dizer, os materiais e o sistema de construção adotados: depois o "p pido", ou s ja de quen nue dizer, os materiais e o sistema de construçâo adotados; depois, o "partido", ou seja, de que maneira, com a utilizaçăo dessa técnica, foram traduzidas, em termos de arquitetura, as determinaçōes daquel programa $(\ldots . .)^{13}$

A sua abordagem está claramente comprometida com paradigmas e conceitos modernos, como partido, intençóes plásticas, programa de necessidades e com a concepção da arte como expressão de uma cultura específica, oferecendo possibilidades aos historiadores de explicaçáo das forma artísticas a partir de valores autônomos, nascidos da acentuação de especificidades nacionais e regionais. Acreditava ele, de acordo com Aracy Amaral, que as primeiras manifestaçóes de uma arte realmente brasileira encontravam-se nas antigas capelas mineiras feitas pelos paulistas. ${ }^{14}$

${ }_{10}$ SOLA - MORALES. "Prólogo a la edición castellana: Teoria e Historia del arte en la obra de Alois Riegl." In: RIEGL, Alöis Problemas de estilo. Fundamentos pra una historia de la ornamentacion. Trad. De Frederico M. Saller. Barcelona: Editorial Gustavo
Gili, 1980.

${ }^{11}$ Nessa linha historiográfica estâoo Lúcio Costa, Sylvio de Vasconcellos, Paulo Santos, Carlos Lemos, dentre outros.

${ }_{12}$ PUPPI, Marcelo. Por uma historia não moderna da arquitetura brasileira. Campinas: Pontes, 1998. p. 18-32.

${ }_{13}$ Lúcio Costa, "A arquitetura dos jesúftas no Brasil" "In: Revista do Patrimônio Historico e Artistico Nacional. 60 anos: a revista. Org.

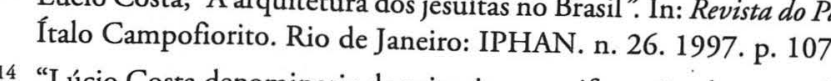

14 "Lúcio Costa denominaria de primeiras manifestaçóes de arte realmente brasileiras essas capelas mencionadas de Săo Paulo, no contexto de uma história da arte que, em nosso país, apenas se iniciou de fato em meados ou fins do século XVII". AMARAI
Aracy. "Da terra: Madeira e barro como suporte para a cor e o Aracy. "Da terra: Madeira e barro como suporte para a cor e o ouro". In: Revista Barroco. Belo Horizonte: SPHAN/UFOP, n. 12,
1982/3. p. 281.
Corroborando essa posição, diz Marcelo Puppi:

Esse comprometimento fica claro na formulaçăo teórica de Lúcio Costa, quando se percebe os vínculos de suas leituras à constante busca das raízes da nação, dificultando o estabelecimento das necessárias conexóes e intercâmbios com o panorama internacional. Como resultado desse trabalho, a ênfase em suas análises sempre foi a da busca de um espírito geral de nossa arquitetura e num modelo histórico que se baseou, fundamentalmente, na noção de funcionalidade do moderno. ${ }^{15}$

Na mesma matriz teórica de Lúcio Costa, encontram-se Sylvio de Vasconcelos, Paulo Santos, Germain Bazin, Robert Smith e outros de sua geraçáo, cujos princípios teóricos podem ser inferidos das suas análises da arquitetura mineira, como aqueles, por exemplo, que relacionam o desenvolvimento das formas a processos evolutivos, a espírito de época ou a condicionantes regionais.

Nos seus estudos das igrejas ouropretanas, Paulo Santos avalia os processos evolutivos das formas:

(...) a evolução dos partidos em planta é muito bem caracterizada pela linha geral da Composiçăo e pelas respectivas formas e proporçôes; principalmente das naves e das torres. As formas, a princípio rígidas, foram amolecendo e se arredondando, ao mesmo tempo que as proporçóes, de pesadas, robustas, foram se arredondando, adquirindo elegância. Como conseqüência, a disposiçâao geral, enquadrada numa marcaçăo muito forte, fechada, fracionada em compartimentos muito distintos, foi se tornando flexível, elástica, amalgamando-se os compartimentos principais (...).

(...) A matriz de Nossa Senhora da Conceição de Antônio Dias e a igreja São Francisco de Assis caracterizam muito bem o "sentido" em que se processou essa evolução, representando a primeira a fase inicial e a segunda, a final. ${ }^{16}$

De acordo com essa sua compreensão, a arquitetura mineira teria se iniciado pelas tradicionais formas retangulares, até chegar a uma progressiva complexidade formal curvilínea, cujos termos seriam as igrejas do Rosário de Ouro Preto e São Pedro de Mariana, com plantas formadas de elipses entrelaçadas.

Aqui, o viés semperiano cede lugar a uma abordagem de caráter formalista, na medida em que se observa uma clara contraposição entre as formas estáticas, rígidas e de unidade simples e as mais dinâmicas, flexíveis e de unidade mais complexa, marcando, assim, o processo evolutivo. Essa perspectiva evolucionista é influenciada, sobretudo, pelos teóricos Alöis Riegl e Heinrich Wölfflin, que minimizaram os determinantes de ordem técnico-material e valorizaram a lógica das formas. Sylvio de Vasconcellos também se aproxima desse ponto de vista:

As plantas de nossos templos, desde os primeiros séculos, preferem os partidos retangulares de origem basilical, que, excepcionalmente, evoluem para soluçóes poligonais e circulares de origem bizantina, revividas, no barroco, principalmente por Borromini. ${ }^{17}$

${ }_{15}$ PUPPI, Marcelo. Op. cit., p. 18.

${ }^{16}$ SANTOS, Paulo. Subsidios para o estudo da arquitetura religiosa em Ouro preto. Rio de Janeiro: Kosmos. 1951. p. 131-132.

${ }_{7}{ }^{17}$ VASCONCELLOS, Sylvio de. "A arquitetura colonial mineira". In: AVILA, Afonso. Teorias e analise do Barroco. Săo Paulo:
Perspectiva. 1997. p. 363. 
De outro lado, essa mesma abordagem formalista vem alinhada às correntes teóricas que valorizam as condiçôes do meio como propulsoras do processo evolutivo. Entendido como determinante máximo da evoluçáo das formas, o estudo dos condicionantes do meio predomina na maioria das investigaçôes sobre arquitetura brasileira, como se observa nas interpretaçôes de Sylvio de Vasconcellos:

Meio antes de tudo hostil, rude, difícil, sem transportes, sem recursos de subsistência, desatendido pelo poder Real, que só visava ao ouro a qualquer modo obtido. Sertáo bravo, afastado do litoral, que se beneficiava do transporte marítimo, com um clima substancialmente diverso do da metrópole e secas periódicas, o calor, os bichos do mato, a mão escrava inteiramente dedicada à mineração, todos esses fatores que năo podiam, de fato, propiciar uma arquitetura mais notável $(. . .)^{18}$

Também Carlos Lemos apóia suas explicaçôes nesses parâmetros. Sua compreensão da arquitetura enfatiza, particularmente, o conceito de "partido", entendido como "uma consequiência formal derivada de uma série de condicionantes ou determinantes [da criaçáo de espaços]; seria o resultado físico da intervenção sugerida". ${ }^{19}$

Nesse enfoque, suas análises fundamentam-se na maneira como os aspectos econốmicos, geográficos e tecnológicos, tais como clima, relevo, materiais disponíveis e mão de obra, atuam e condicionam a forma, explicando a arquitetura que se multiplicou no litoral brasileiro como fruto de "transferências" de modelos europeus adaptados às condiçôes climáticas da região. E, para as culturas isoladas, implantadas em locais distantes do litoral, como São Paulo e Minas Gerais, ele avalia a "recriação" dessas formas condicionadas pelos aspectos geográficos e tecnológicos, configurando obras com características inerentes às condições regionais, que permitiram a criação de uma arquitetura verdadeiramente brasileira.

Em Goiás, as publicações divulgadas sobre a arquitetura colonial local também adotaram pressupostos interpretativos semelhantes, embora nem sempre explícitos.

Em O barroco no Brasil ${ }^{20}$ e Arte sacra: berşo da arte brasileira, ${ }^{21}$ Eduardo Etzel apresenta o mais completo dossiê sobre a arquitetura religiosa setecentista em Goiás. Foi o primeiro autor a levantar informaçōes sobre essa arquitetura e a interpretá-la, baseado fundamentalmente na bibliografia brasileira e na coleta de informaçóes locais, reunindo importantes dados para um retrato da arte goiana. Seus estudos apresentam um quadro geral sobre as condiçốes históricas e culturais da antiga capitania, seguido da catalogaçáo dos edifícios religiosos existentes e do levantamento dos seus retábulos e imagens.

Esse seu trabalho pioneiro constitui um glossário descritivo dos monumentos existentes no Estado, um mapa da arquitetura religiosa de Goiás e, portanto, uma importante referência para estudos posteriores. Nele se encontram as primeiras exposiçóes interpretativas da arquitetura goiana que se

18 Op. cit., p. 352.

19 LEMOS, Carlos A. C. Arquitetura brasileira, Săo Paulo: Editora da Universiddde de Săo Paulo, 1979. p. 9.

${ }^{20}$ ETZEL, Eduardo. O barroco no Brasil. São Paulo: Melhoramentos, 1984

${ }^{21}$ ETZEL, Eduardo. Arte sacra: berç da arte brasileira. São Paulo: Melhoramentos, 1984. vinculam às concepçóes evolutivas da forma associadas à idéia de "partidos". Etzel diz ter encontrado, em Goiás,

(...) o partido mais simplificado de igrejas coloniais. Um primeiro tipo com a nave retangular con empena ou já, raramente, com o frontão triangular. Desse partido inicial o estágio seguinte - o segundo tipo - sio as igrejas assim simples, mas com torres cobertas com alto telhado de quatro águas, encurvado e com beirais. ${ }^{22}$

E seu trabalho termina também por incorporar a visáo decadente dos viajantes estrangeiros para justificar a simplicidade da arquitetura local. Em suas conclusóes, diz:

Estudando o barroco dessa imensa regiáo, nada pude registrar da arquitetura, já que ela pouco ou nada tem de barroco. Ative-me assim ao interior dos templos, descrevendo os retábulos e estudando os percalços de sua construçăo. No presente estudo, pretendo contemplar aquelas informaçóes com a visăo do exterior desses mesmos templos, cuja construção está intimamente ligada aos acontecimentos sócio econômicos do século XVIII, o que torna imperioso o registro deste aspecto próprio do início das artes dentro do panorama brasileiro. ${ }^{23}$

Em Notícias gerais da capitania de Goiás, importante referência documental para a história de Goiás, publicada por Paulo Bertran, também encontram-se conceitos e entendimentos que relacionam a forma arquitetônica com as condiçôes tecnológicas e regionais. Para Paulo Bertran:

(...) a arquitetura [de Goiás] sujeitou-se `a ditadura do barro e da madeira. Até mesmo o amálgama da taipa de piláo foi rareado, talvez por conta, por falta de uma química de materiais satisfatória.

É possível que a investigaçáo geológica da disponibilidade de materiais construtivos melhor explique essa engenharia sertaneja, essa arquitetura Planaltina, do que propriamente a reminiscência cultural de design indígena, ou piratiningano ou lusíada. ${ }^{24}$

Em recente artigo, "500 Anos: Algumas reflexões à margem do vernáculo histórico de arquitetura brasileira” ${ }^{25}$ Bertran não só se apresenta como seguidor dos historiadores modernistas clássi${ }^{20}{ }^{26}$ como também identifica a arquitetura de Goiás como fruto das raízes locais, de caráter fundamentalmente vernacular, nomeando-a Vernáculo barroco colonial brasileiro. Nesse mesmo artigo, sua mentalmente vernacular, nomeando-a Vernáculo barroco colonial brasileiro. Nesse mésmo artigo, sua tania de Goiás manteve com Portugal e capitanias adjacentes. Conclui, por todas as suas observaçóes de pesquisador e historiador,

\section{Op.cit, p. 139 .}

${ }^{23}$ Idem. p. 198.

24 BERTRAN, Paulo Nottcia geral da Capitania de Goiás. Goiânia: UCG, UFG; Brasilia: Solo Editores, 1996. p. 51.2 v.

25 BERTRAN, Paulo. "500 Anos: Algumas reflexōes à margem do vernáculo histórico de arquitetura brasileira". In: Revista Momento. Goiânia: UCG, n. 8, abril de 2000 .

26 "No que nos habituamos chamar de vernáculo barroco colonial brasileiro talvez tảo só tenhamos uma idéa tornada em ideologia, crescida à sombra da grande e genial árvore do inventor do patrimônio histórico brasileiro - Rodrigo de Mello Franco - estendendo suas generosas galhadas por sobre Lucio Costa, 5 
(...) que pouco existe de arquitetura colonial brasileira, a menos que a consideremos apenas como marco político, o que não pode ser determinante em matéria de tradiçóes construtivas. Existe arquitetura antiga devidamente miscigenada com inevitáveis estilos e modas do grande ramo do vernáculo ocidental - mas estrutural, funcionalmente e mesmo arquitetonicamente é fundada cois brasileira. ${ }^{27}$

As conclusões de Gustavo Coelho sobre a arquitetura nas vilas do ouro não diferem substancialmente das de Bertran. Para ele, "a arquitetura goiana é, então, dentro de toda essa simplicidade que a caracteriza, um misto de elementos construtivos e programáticos trazidos quer por paulistas quer por portugueses e elaborados de uma forma bem própria e com características regionalizadas". ${ }^{28}$ Quando discute esse tema em sua dissertaçáo de mestrado, compreende também a arquitetura através de concepçóes que justificam as formas a partir dos condicionantes do meio físico, que explicam as características regionalizadas da arte. Considera que:

(...) os exploradores paulistas tiveram problemas com a implantação, nesse novo território, da arquitetura característica de sua regiáo de origem, principalmente em decorrência de ser um terreno acidentado das regióes de mineração impróprio para construçōes que utilizassem as técnicas construtivas empregadas por esses desbravadores. Como conseqüência, vão surgir novas interferência portuguesas, como adoção de técnicas e elementos construtivos que, adaptados às questôes regionais de clima, topografia e materiais disponíveis, produzem uma arquitetura com características próprias, que estarão mais de acordo com as especificidades da região a ser ocupada. ${ }^{29}$

Já no artigo "Construçôes religiosas do período colonial existentes na região de Vila Boa: 1727/1793”, Gustavo Coelho, apesar de minimizar essa interpretaçáo, ainda deixa aflorar vestígios da influência de Etzel, cuja leitura se guia pelos olhares dos antigos viajantes do século passado. Diz que:

Vários fatores podem ser enumerados entre os que provavelmente contribuíram para a existência de tais diferenças [entre a arquitetura de Minas Gerais e de Goiás]. Entre elas, podemos citar a distância dos centros culturais do litoral (...). Assim de acordo com Etzel, os aventureiros detentores de um grau cultural mais elevado, ao se dedicarem à atividade da mineraçăo, privilegiavam a regiảo de Vila Rica, ficando para as regiôes mineradoras mais distantes o interesse dos aventureiros mais rudes, com nível cultural menos avançado, exatamente aqueles dispostos a enfrentar as grandes distâncias e todo tipo de dificuldades, especialmente as relacionadas a questốes de abastecimento e de assistência. ${ }^{30}$

De modo geral, Gustavo Coelho descreve e registra cuidadosamente a história dos monumentos goianos. Dentre todos os estudiosos do assunto, foi o que maior contribuição trouxe para historiografia arquitetônica colonial de Goiás. Seu trabalho, de grande pesquisa documental, foi o

\section{${ }^{27}$ Idem. p. $4-5$.}

${ }^{28}$ COELHO, Gustavo Neiva. A formaģăo do espaf̧o urbano nas vilas do ouro: o cass de Vila Boa. Dissertaçăo de mestrado. Goiâni ${ }_{29}$ Idem. p. 189

${ }^{29}$ Idem. p. 18 30 COELHO, Gustavo Neiva. "Construçóes religiosas do período colonial existentes na região de Vila Boa: 1727/1793." In
Revista Fragmentos de Cultura. Goiânia: UCG/IFTTEG. v. 9, n. 3, maio, junho 1999. p. 612. primeiro a avançar sobre as questóes formais e as dos elos que ligam os tipos da arquitetura goiana com os de outras regióes.

Outra publicaçăo local, Patrimônio histórico de Goiás, de autoria de Luís Palacin e Ana Maria Borges, traz dados históricos gerais sobre os antigos edifícios remanescentes de toda a Capitania. No entanto, mesmo não sendo um trabalho analítico, em algumas das suas exposiçóes incorpora o conceito de decadência provindo dos viajantes, como se pode observar nessa passagem:

A penúria da época em que foram construídos esses edifícios explica suas proporçóes modestas A penta da por Vila Boa a única vila na Capitania e receber, portanto, a metade da arrecadaçăo dos outros arraiais. A proliferaçăo da construçóes - sete igrejas construídas entre sessenta e noventa - talvez encontre sua explicaçáo no desemprego pela decadência da mineração.

Essas são, no geral, as interpretações que se formaram no quadro da historiografia artística de Goiás. No conjunto, apresentam-se como trabalhos importantes, principalmente quanto ao "corpus" documental. Mas esse acervo cultural, porque pioneiro, merece acréscimos advindos de interpretaçóes mais afastadas dos princípios da arte moderna como parâmetros de avaliaçáo de monumentos do passado, bem como das leituras que apostam na regionalidade da arquitetura a partir de condicionantes geográficos e tecnológicos, e do conceito de decadência.

A última metade do século $\mathrm{XX}$ tem se empenhado em rever esses pressupostos e em buscar novas interpretaçóes e abordagens. Nesse sentido, Myrian de Oliveira aponta caminhos balizados por um estudo fundamental, publicado em 1955, na cidade de Nova York, pelo pesquisador John Bury, um ano antes da publicaçáa, em Paris, do livro de Germain Bazin. Nesse estudo, Bury apresenta um outro ponto de vista em relação aos processos evolutivos e contínuos da arquitetura de Minas Gerais, exemplificados pelas igrejas do Rosário de Ouro Preto e São Pedro de Mariana. Para ele, ao invés de marcos finais de um processo evolutivo que se desenvolveu na colônia, são essas igrejas caracterizadas como um episódio isolado de uma breve "fase barroca" na arquitetura da região, entre 1740 e 1760 aproximadamente, antecessora do rococó da segunda metade do século. ${ }^{32}$

O trabalho de Bury, junto aos de Rafael Moreira, Horta Correia, José Fernandes, Myrian de Oliveira, Manuel Teixeira e Margarida Valla, pesquisadores portugueses e brasileiros que se dedicam ao estudo da arquitetura e do urbanismo, vêm abrir possibilidades para novos enfoques e reflexóes sobre a arte colonial, capazes de complementar os estudos anteriores.

No âmbito específico da arquitetura portuguesa, o texto de George Kubler, "Portuguese Plain Architecture between Spices and Diamonds (1521-1706)", foi a marca propulsora do início de uma nova etapa da historiografia artística lusitana, com a identificação de uma grande corrente artística denominada "châ" que, segundo Carlos Lemos, se estendeu e alcançou o Brasil, sendo a representante

31 BORGES, Ana Maria PALACIN, Lứs. Patrimônio historico de Goiás.Brasslial SPHAN. 1987. p. 9. 32 OLIVEIRA, Myriam Andrade Ribeiro de. $O$ rococó religioso em Minas Gerais e seus antecedentes europeus. Paris:Universite Catholique et Letrres, 1990. p. 4.2 v. 
de "quase toda a produção da arquitetura brasileira do século XVI aqui levada a efeito pelos arquitetos portugueses, incluídos entre os construtores militares e entre os padres jesuítas." 33

Assim, verificar as possíveis influências dessa e de outras vertentes na arquitetura setecentista de Vila Boa pode constituir um terreno bastante fértil, na medida em que a colônia sempre manteve um diálogo com Portugal, mesmo em regiôes mais centrais, como aponta Rafael Moreira:

É em Minas Gerais que devemos acompanhar o seu prosseguimento [artístico, que tinha como ponto de partida o litoral], combinado com novas importaçôes culturais da metrópole, já não no estilo da corte, mas do foco provinciano nortenho, numa síntese deveras feliz. Os seus frutos não podiam ser mais delicados, criando esse peculiar gosto pelo rococó que o celebrizou, mas cujas raízes estão mais no Minho e no estudo da tratadística e de gravuras barrocas européias do que em qualquer outro lado. ${ }^{34}$

A partir dessas consideraçóes, o presente estudo sobre a arquitetura religiosa de Vila Boa de Goiás caracteriza-se, em primeiro lugar, pelo abandono de conceitos como o de história universal, progresso, decadência e princípios que orientaram as interpretaçôes da arte moderna. Sua realizaçáo não se atem apenas às leituras consagradas que entendem a arquitetura sobretudo como uma relaçáo direta dos processos evolutivos formais, dos condicionantes geográficos e dos recursos tecnológicos. Mais do que trabalhar com as especificidades regionais, privilegiou-se entender essa arquitetura a partir de um universo cultural, Vila Boa de Goiás, formado por uma realidade complexa que aponta orientaçóes interpretativas diferentes das que foram consolidadas pela historiografia tradicional.

A pesquisa iniciou-se segundo uma criteriosa reavaliação das fontes documentais, manuscritos e imagens, no sentido de buscar novas informaçóes sobre os planos arquitetônicos, sobre os autores das obras, os desenhos e as fases de execução dos edifícios, realizados por diferentes grupos de artesãos. Considerou também a importância das igrejas na formação da cidade, suas formas de implantação e a articulação que elas estabeleceram entre si e com o seu entorno. $O$ entendimento da organizaçáo do trabalho do artesão goiano setecentista, de seus aspectos burocráticos, da estrutura dos canteiros de obras e das participaçóes dos erectores foi de grande importância na medida em que proporcionou estabelecer uma relaçáo da arquitetura com os diferentes agentes do processo construtivo. Por fim, a pesquisa também buscou identificar os tipos arquitetônicos existentes na Vila, através dos vários intercâmbios que ela manteve com a metrópole portuguesa e com as capitanias de Minas Gerais e de São Paulo, regióes adjacentes que muito influenciaram Goiás.

A organização da dissertação desenvolveu-se em quatro momentos de estudo, que se apresentam em quatro capítulos que discorrem sobre as características da arquitetura religiosa de Vila Boa em diferentes aspectos.

Em $A$ igreja e a cidade, discute-se a importância atribuída ao edifício religioso na formação e articulação do espaço urbano de Vila Boa, a partir de três momentos caracterizados por práticas de

${ }_{33}$ LEMOS, Carlos. "No Brasil, a coexistência do maneirismo e do barroco até o advento do neoclássico histórico". In: AVILA, Affonso. Barroco: teoria e análise. Săo Paulo: Perspectiva, 1997. p. 237. ${ }^{34}$ MOREIRA, Rafael “A arte luso-brasileira: modelos, sintese, autonomia”. In: Historia da Expansääo Portuguesa. Portugal: Círculo
de leitores e autores, 1988. p. 487. "fazer cidades" bastante diferenciadas: no Arraial de Santana, encontram-se as marcas do mais tradicional sistema de organização espacial, para o qual o edifício religioso foi o principal elemento orientador; a fundação da Vila introduziu novos conceitos urbanísticos, nos quais a praça, a marcação de um edifício religioso e a Casa de Câmara e Cadeia foram os elementos inovadores e norteadores de uma nova organização espacial; o terceiro momento foi marcado pelas intervençóes de reformadores que, ao se preocuparem com as distorçóes do plano da Vila, buscaram alternativas para o realinhamento do traçado.

O capítulo $O$ edificio da ordem social estuda a arquitetura a partir das iniciativas das irmandades leigas e de particulares para a construção das igrejas, mas também compreende que o soerguimento dessas capelas não foi feito simplesmente a partir do desejo de seus erectores. As exigências legais também se fizeram presentes em Vila Boa, com uma série de encargos e obrigaçóes previstos pela Constituição do Arcebispado da Bahia, excluindo a idéia de que essas igrejas tenham sido levantadas aleatoriamente. No tecido urbano, cada um dos edifícios, avaliados pelo seu grau de importância e imponência, marcou o espaço urbano de Vila Boa, denunciando uma estrutura social hierárquica e excludente.

O terceiro capítulo, As construçóes, mostra como as relaçóes entre as formas de organização de trabalho dos construtores vilaboenses condicionaram a construção dos edifícios, reconhecidos, em geral, por suas descontinuidades construtivas e estilísticas. Organizados em grupos, esses profissionais realizaram trabalhos especializados, com a presença ou náo de traças, avaliaçōes e peritagens, que se constituíram em procedimentos importantes e determinantes para as características dessa arquitetura.

A arquitetura: referências tipológicas mostra como a arquitetura religiosa de Vila Boa sempre manteve um permanente diálogo com as capitanias de Minas Gerais, São Paulo e mesmo Portugal, com o exemplo da Matriz de Santana. Tipos de nave única retangulares e octogonais foram bastante comuns na Metrópole, mas, em território colonial, apenas os retangulares espalharam-se e multiplicaram-se amplamente. Os octogonais, por serem mais raros, constituíram uma particularidade no cenário da arquitetura, o que incitou a pesquisa a acreditar que, embora grandes as distâncias em relaçáo ao litoral, a região da Capitania de Goiás não se manteve tão isolada. 


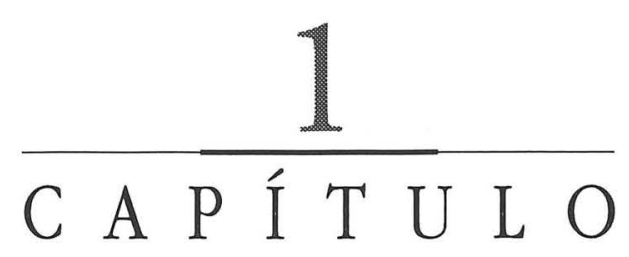

A IGREJA

E A CIDADE 

arquitetura religiosa dos séculos XVII e XVIII desempenhou papel importante na configuração das cidades coloniais brasileiras, organizando-se a partir de diferentes articulaçóes com seu entorno e marcando de forma expressiva suas concepçóes como referência nas paisagens urbanísticas. Agiu como elemento organizador e formador de espaços hierarquicamente dispostos e como representante simbólico da tensáo entre o sagrado e o profano. Podem-se explicar, portanto, algumas das complexidades e particularidades que envolveram a constituição do espaço religioso das cidades setecentistas a partir das relaçóes que as igrejas mantiveram com diferentes concepçóes urbanas desenvolvidas no contexto das experiências da Expansão Ultramarina. Nesse período, em que se encontram as raízes do urbanismo colonial brasileiro, Portugal formou um programa de fundação de cidades com novas práticas urbanísticas que caracterizaram uma realidade extremamente complexa, como adverte Rafael Moreira:

Ao longo desses 5 séculos houve logicamente uma evolução na maneira de entender, conceber e fazer funcionar as cidades em latitudes tão diversas, que mostra a modernidade do processo expansionista lusitano como uma dinâmica de experiências em continuidade do séc. XV ao iluminismo pombalino, pelo menos. ${ }^{1}$

Vila Boa de Goiás, ao inserir-se no contexto expansionista, estabeleceu vínculos que permitem remontar seu espaço urbano a várias experiências portuguesas, na medida em que apresenta uma formação marcada por momentos distintos, como o da formação do Arraial de Santana, o da fundaçáo da Vila e o das reformas de 1782, propostas pelo governador Cunha Menezes. Sob tal perspectiva, pode-se reconhecê-la como resultado de sínteses de diferentes modelos e concepçóes de cidades, realizadas num curto período de tempo.

$\overline{1}$ MOREIRA, Rafael. "A arte da ruação e a cidade luso-brasileira (séc. XVI-XVIII)". V Seminário História da cidade e do urbanismo. PUC Campinas, out., 1998. p. 4. 


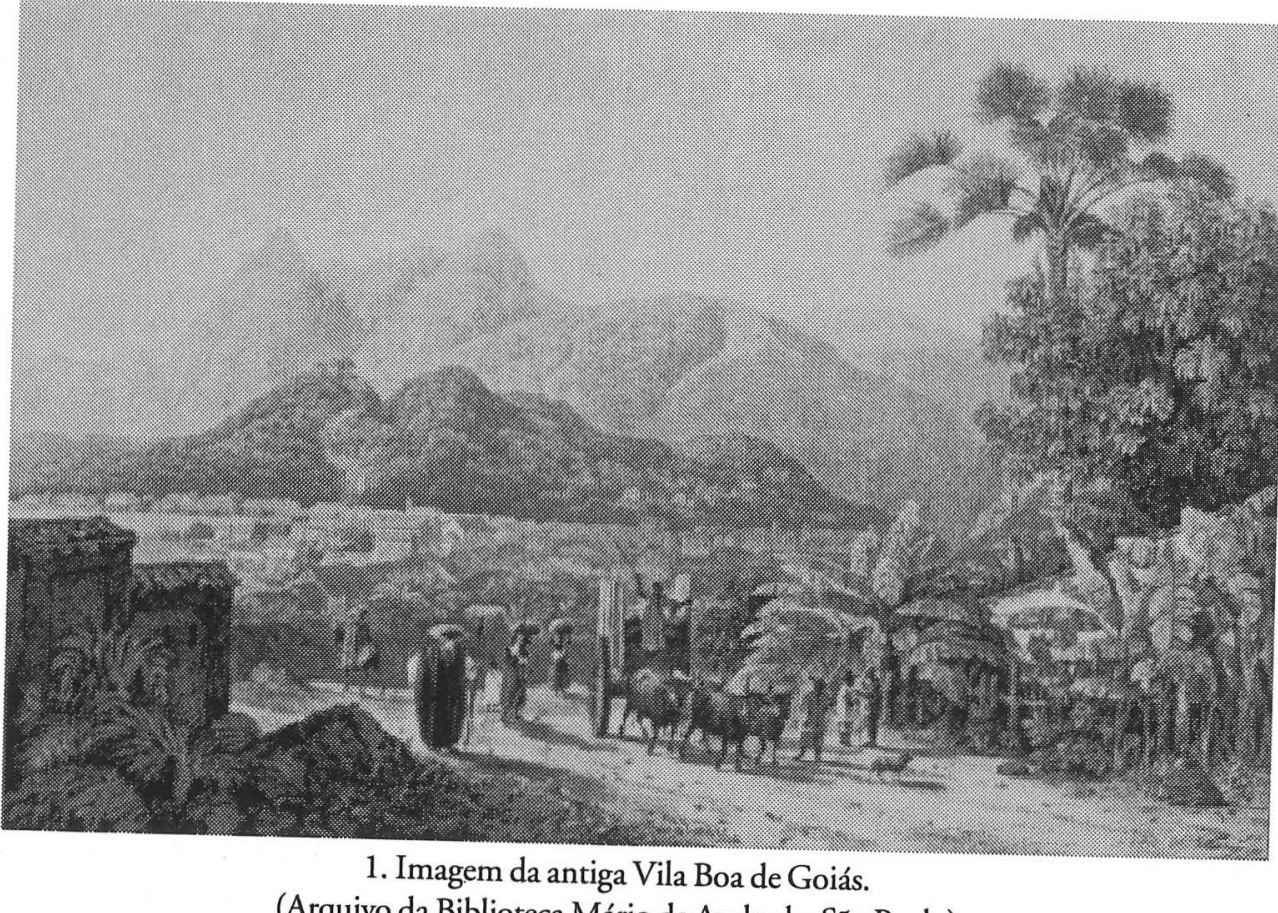

(Arquivo da Biblioteca Mário de Andrade, Săo Paulo)

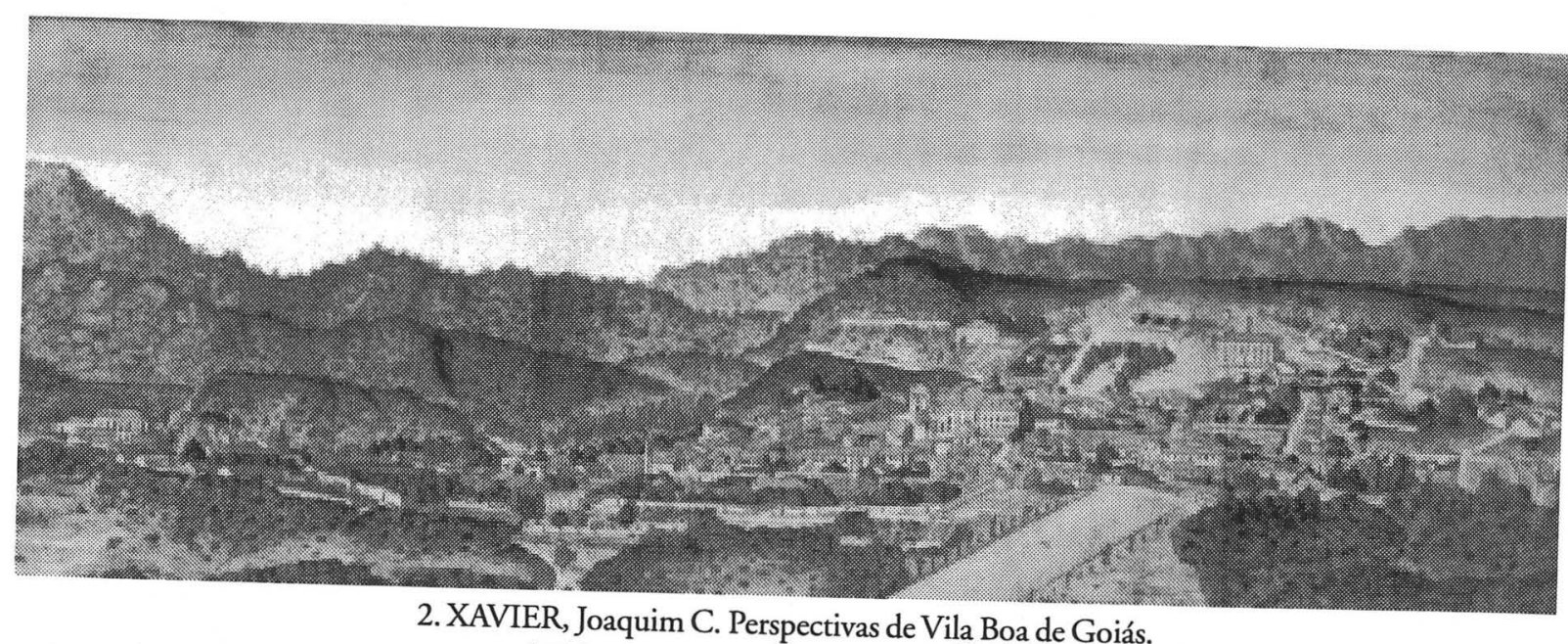

(Biblioteca Mário de Andrade, São Paulo)
1.1 O URBANISMO PORTUGUÊS E A FORMAÇÃO DE VILA BOA DE GOIÁS

O Arraial de Santana iniciou-se em julho de 1726, com a chegada da bandeira de Bartolomeu Bueno da Silva às margens do Rio Vermelho. Faziam parte de sua expedição paulistas, portugueses, padres, negros, índios e os engenheiros militares ${ }^{2}$ Manuel de Barros ${ }^{3}$ e Manoel Pinto Guedes. $\mathrm{O}$ arraial foi um exemplo de ocupaçáo territorial feita por colonos em decorrência da exploração do ouro. Sua concepção privilegiou aspectos topográficos da regiáo, desenvolvimento linear às margens da estrada que vinha de São Paulo ${ }^{4}$ e a construçáo de uma primitiva capela em um lugar distante do rio, marco de fixaçáo e primeiro espaço fundacional da cidade.

Em 1736, por questóes de manutenção de poder e maior controle por parte da metrópole, a Capitania de Goiás desmembrou-se da de São Paulo e recebeu ordens reais para a fundação de sua capital, o que só se cumpriu em 1739. O Conde de Sarzedas, inicialmente designado para a execuçáo da tarefa, faleceu em 1737, no arraial de Meia Ponte, ${ }^{5}$ prorrogando a fixaçăo de Vila Boa até 1739, quando o sucessor do governador de São Paulo, Luís de Mascarenhas, finalmente a demarcou:

(...) com o Patrimônio de quatro léguas de terra que sua Magestade lhe concedeu pela ordem, que consta da certidão $\mathrm{n}$. 1, datada em 11 de fevereiro de 1736, na qual se determina que no terreno junto a Vila fique bastante extensão para Logradouro público, e para neles se poderem retificar novas casas e serventias de cujo terreno, se não podiam em tempo algum dar sesmaria ou aforamento sem ordem especial do dito senhor.

A Vila, como outras, foi um assentamento com funçáo básica de centro administrativo e irradiação de serviços de supervisão governamental. Para tanto, assumiu a ordem espacial com que expressava o seu novo papel político, representado simbolicamente pelas demarcaçóes do Largo do Chafariz ou da Boa Morte e dos limites para a construção de novos edifícios.

Para o exercício da primeira sede administrativa, estruturas urbanas e políticas foram montadas, como a criação da Câmara Municipal, a formação da primeira paróquia e a elevaçáo da antiga Capela de Santana a Matriz. Essas providências garantiram novo status ao local: originalmente nascido para ser um simples arraial, ampliou-se pela incorporação de uma área destinada a vila, passando a ser definitivamente a capital de Goiás.

2 TELES, José Mendonça. Vida e obra de Silva e Souza. Goiânia: UFG. p. 77.

3 A carta patente de Manuel de Barros encontra-se registrada em antigo livro do arquivo português de decretos:

"Nomeando capitão do regimento de infantaria do tenente-coronel Figueiredo Sarmento e as pessoas seguintes: Antonio Sarmento Pereira, alferes do regimento do coronel Francisco Luis Pequeno, Bernardo Sarmento Pereira e Manuel de Barros,

$4 \mathrm{Em}$ momento posterior, esse trecho de estrada se ligou ̀̀ que alcançaria Cuiabá.

5 O antigo Arraial de Meia Ponte é a atual cidade de Pirenópolis.

6 Oficio da Câmara de Vila Boa ao governador Luís da Cunha Menezes. 24 de julho de 1779. Apud: BERTRAN, Paulo. Notcicia geral da capitania de Goiás. Goiânia/ Brasília: Solo Editores, 1997. p. 60. 2 v.

7 Esse documento também pode ser encontrado junto aos manuscritos avulsos do Arquivo Frei Simão Dorvi, cidade de Goiás.

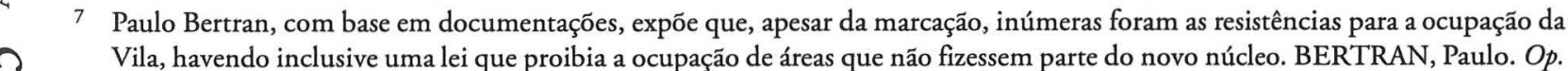


Na segunda metade do século XVIII, encontram-se as maiores transformaçóes no seu traçado, desenvolvidas em torno de práticas orientadas por determinações pombalinas, como as reforma urbanas de José de Almeida e Luiz da Cunha Menezes. Esse último, em 1782, reordenou as estruturas físicas de Vila Boa, reparando as imperfeições que se seguiram às primeiras demarcações do plano de fundaçáo feitas pelo governador Luís de Mascarenhas que, segundo Roberta Delson, seguiu apenas "as ordens referentes à construção dos prédios públicos necessários, mas foi negligente em exigir o cumprimento do padrão reticular no traçado das ruas. Dessa forma, compreende-se por que muito depois, na década de 1770, foram expedidas ordens recomendando que fosse estabelecido um plano direto para Vila Boa a fim de futuramente evitar "a mesma irregularidade... com que os fundadores da Capital haviam construído os prédios, estragados pela falta de alinhamento". ${ }^{8}$

Apesar de todas as preocupaçóes urbanísticas de José de Almeida, mandando executar calçadas, pontes e um magnífico Chafariz, foi o governador Cunha Menezes quem se tornou o maio reformador urbano de Vila Boa, com propostas de realinhamento do traçado da Vila e um código de posturas que definiu a uniformidade das fachadas e áreas para construçôes de novos edifícios.

Mas a variedade de modelos urbanos introduzidos no Brasil conduziu pesquisadores da historiografia a interpretar as características de inúmeros assentamentos urbanos como configuraçóes puramente espontâneas, irregulares e indisciplinadas, relacionadas, na sua tipologia, às cidades medievais, nascidas sobre uma eminência fortificada e que associavam as suas tortuosas e orgânicas ruas, com seus casarios apertados, à segurança e à defesa. Robert Smith, por exemplo, diz serem tais assentamentos resultados formais urbanos de uma tradiçáo nacional de cidade alta e baixa, pela sua topografia de extrema irregularidade, ausência de grandes superfícies abertas e espaços interligados por ladeiras íngremes, em cujas cotas mais altas estariam assentadas capelas e fortes, configurando a tipologia das cidades litorâneas e núcleos mineratórios do século XVIII.?

Análises como essas e as que estabelecem analogias entre as cidades orgânicas portuguesas e brasileiras conduziram vários pesquisadores a avaliar pejorativamente inúmeras delas, desconsiderando radicalmente outras possíveis ordenaçōes e até legislaçōes que pressupunham um tipo de "planejamento" que regulamentava não só a vida metropolitana como a colonial. Principalmente através das Ordenaçóes do Reino, Cartas Forais e Termos de Assentamentos, os colonizadores conseguiram impor uma certa uniformidade às cidades do século XVIII, com freqüente respeito à topografia e singular valorização dos edifícios religiosos e públicos, que se desenvolveram paralelamente aos largos e praças, em percurso delineado por longos eixos axiais reconhecidos como elementos geradores de espaços urbanos.

Em contraponto a essas leituras que apostam nos denominados crescimentos espontâneos, uma historiografia recente propõe que as práticas urbanísticas na colônia brasileira possibilitaram sínteses construtivas que incorporaram, simultaneamente, conceitos vernáculos e eruditos de cidades. $\mathrm{O}$ modo de fazer cidades, com estruturas lineares e sensíveis às topografias locais, resultou em paisagens

DELSON, Roberta. Novas vilas para o Brasil colônia: Trad. Fernando de Vasconcelos Pinto. Brasilia: Ed. Alva-Ciord, 1997 p. 31. SMITH, Robert C. "Arquitetura civil do período colonial". Revista do Patrimônio Historico e Artístico. Rio de Janeiro: SPHAN.
n. 17, 1969. urbanas nas quais a arquitetura religiosa tornou-se elemento de destaque. Tal concepção constituiu uma lógica de princípios pragmáticos, ligada a soluçóes regionais, diferentemente daquela cujos traçados urbanos se fizeram com esquemas pré-concebidos de desenho de cidades.

Rafael Moreira retrocede a 1455 as origens desse tipo de organizaçáo linear, próprio do chamado urbanismo da Ordem de Cristo, ${ }^{10}$ cujas ruas, que acompanhavam o relevo do terreno, procuravam se manter paralelas e perpendiculares, formando um "esquema bipolar traçado em forma de cruz, com o símbolo da Cruz da Ordem de Cristo, que determinava, pela repetiçăo dos quarteirôes e lotes, uma estrutura linear orientada para o porto, marítimo ou fluvial, ou a principal estrada."

Para o autor, provavelmente essa foi a lógica de formação de algumas cidades brasileiras que e desenvolveram em regióes de povoados mineiros: estruturas urbanas tendencialmente regulares. Ao se desenvolverem, apresentaram, ao mesmo tempo, soluçôes tradicionais e inovadoras, que definiram um novo "urbanismo" em parte comprometido com concepçôes renascentistas italianas, como "a empírica Arte ou Ciência da Ruação, uma teoria empírica, e sobretudo pragmática, de terreno mais que de gabinete, a que se procurou dar credibilidade e forma científica no século XVIII, mas que é [era] fruto de uma evolução específica do império português com raízes no Portugal do passado medieval, na sua situação de país-limite da Europa". ${ }^{12}$

A Arte ou Ciência da Ruação ${ }^{13}$ foi, portanto, o "urbanismo" que se firmou na formaçáo das cidades setecentistas brasileiras, constituindo sínteses e conjuntos de procedimentos que, gradativamente, foram substituindo referências mais antigas. Com a Ciência da Ruaçáo, desenvolveu-se a "utopia ligada à ideologia do iluminismo e da Idade da Razão [...]. Além dos engenheiros militares, habituados a abrir caminhos e a traçar novas povoaçóes já perfeitamente regulares (como mostram as cartas de fundação de Vila Boa de Goiás e Vila de Icó, 1736, São José do Rio Negro, 1755, e Oeiras no Piauí, 1761, táo idênticas que parecem seguir um formulário pré estabelecido), os agentes do urbanismo regular sistemático serão [foram] os anônimos ocupantes do cargo igual ao medidor, os ruadores." ${ }^{14}$ Com os ruadores, fundaram-se cidades mais regulares, com categorias de apreciaçáo que consideravam ruas planas, construçóes proporcionais e formosas a maneira do Reino.

Nesse tipo de urbanismo, onde práticas urbanas portuguesas se amalgamavam, os edifícios religiosos, nas suas diferentes categorias, como ermidas, capelas e matrizes foram, de diferentes maneiras, importantes elementos de estruturação e ordenação de espaços. Através deles e de suas articulaçóes com ruas, adros, largos e praças, fixaram-se formalmente outras estruturas do tecido urbano que, no conjunto, expressaram as formas de organizaçáo política, social e administrativa da colônia. Com essa lógica de ordenação espacial, com edifícios privilegiados tanto volumétrica quanto simbolicamente, as

10 "Talvez mais sob influência italiana (patente na Vila do Infante fundada pelo infante D. Henrique em 1455 no promotório de Sagres, com a sua correnteza de casas uniformes que se devia repetir em linhas paralelas, como em Pienza), configura-se o que se tem chamado Urbanismo da Ordem de Cristo." MOREIRA, Rafael. Op. cit., p. 4.

Idem. p. 4

Idem. p. 1

13 "Arruar é um verbo de açăo, portanto usado na documentaçăo coeva para exprimir o ato de urbanizar. É que a rua era o

elemento fundamental, a geratriz do espaço urbano português". ROSSA, Walter. Op. cit., p. 268.

n 14 MOREIRA, Rafael. Op. cit., p. 13. 


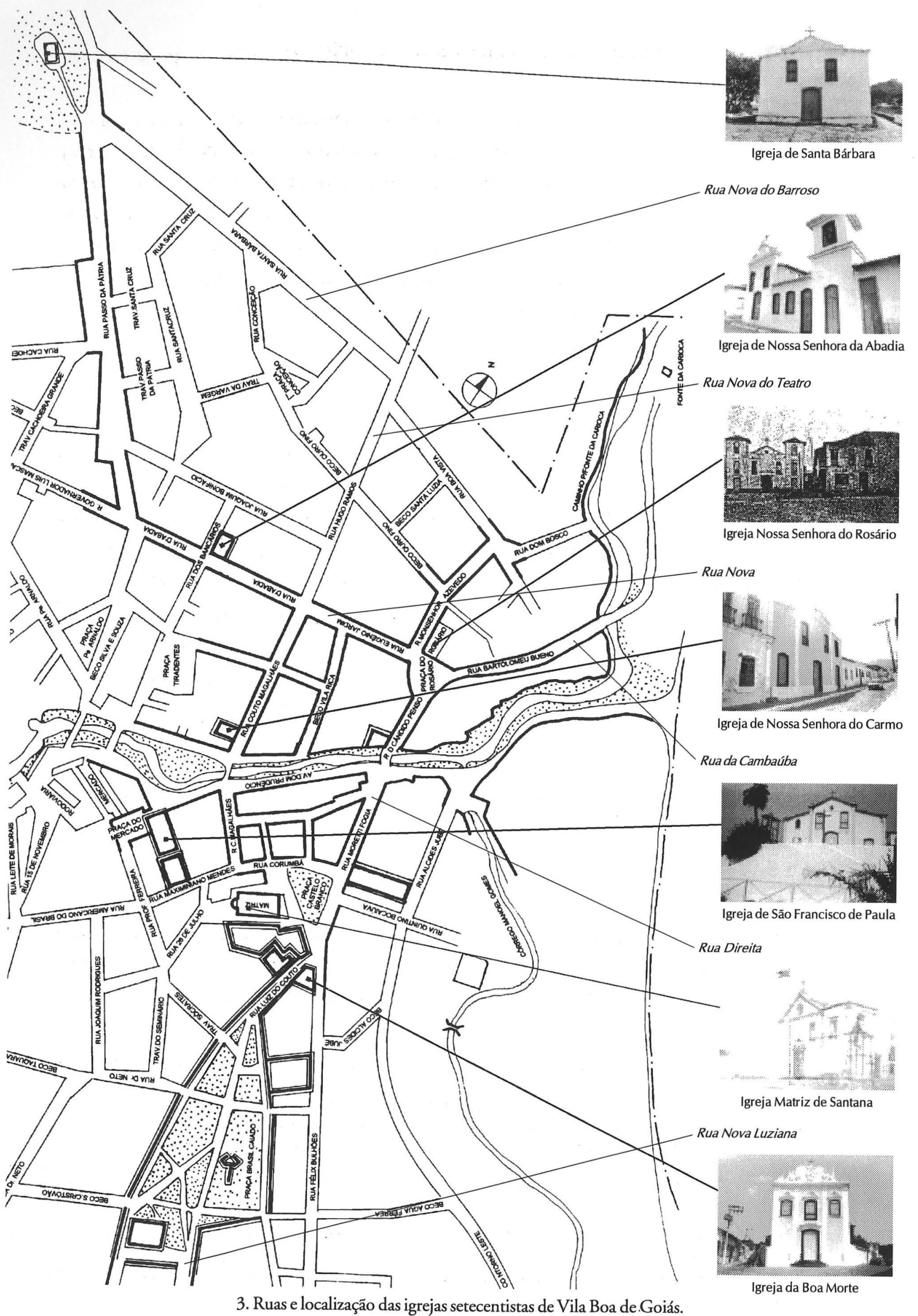

cidades coloniais brasileiras se caracterizaram por uma paisagem edificada de relações espaciais hierárquicas.

Nesse contexto de formaçăo de cidades, na qual a importância dada ao edifício religioso se faz de diferentes maneiras, pode-se explicar a formaçáo da atual cidade de Goiás. Na sua origem, quando Arraial de Santana, configurou-se pelos tradicionais conceitos portugueses de espaço arquitetônico e urbano, que privilegiavam o edifício religioso como elemento estruturante; depois, com a marcaçáo da Vila, assumiu maior regularidade de traçado e, portanto, do desenho como gerador e ordenador do espaço. Esse novo princípio desenvolveu-se lentamente ao longo da segunda metade do século XVIII, em Vila Boa, alcançando maior expressão a partir das reformas do governador Cunha Menezes.

\subsection{O ARRAIAL DE SANTANA E A IGREJA}

O Arraial de Santana ${ }^{15}$ estruturou-se a partir de um "sistema bipolar", similar ao de muitas povoaçóes coloniais, em que "náo havia a obsessão do ângulo reto nem da geometria abstrata, mas a necessidade prática (e o gosto) de abrir ruas tanto quanto possível paralelas, adaptando-se ao relevo - a linha da costa, curso dum rio, nível da cota duma encosta abrigada da intempérie". ${ }^{16} \mathrm{O}$ sistema foi composto por um eixo e extremidades que se formaram por dois largos, onde se implantaram as Igrejas da Matriz de Santana e de Nossa Senhora do Rosário que, juntamente com o traçado linear, auxiliaram a demarcação da extremidade ou limite do Arraial. Esses dois edifícios, ao complementarem o sistema estrutural, funcionaram como importante elemento de orientaçáo para o crescimento do núcleo populacional. A eles coube a

origem dos largos ou terreiros, funcionando como pólos de atração e densificação do tecido urbano. Em termos de linguagem urbana, é mais importante a sua massa e volumetria que o recorte, pois nem mesmo na arquitetura gótica portuguesa a verticalização é um fim. Deve-se apenas à reduzida escala do grosso das restantes construçōes a força com que algumas igrejas emergiam no perfil da cidade.

Assim, as igrejas da Matriz de Santana e Nossa Senhora do Rosário organizaram e articularam os dois principais largos, que se formaram a partir de uma relação direta das escolhas dos locais, cujos sítios apresentaram topografias sensíveis a uma boa visibilidade. Tal soluçáo criou uma disposi-

${ }^{15}$ Esse tipo de formaçăo urbana, que se dá a partir de um eixo com posteriores ruas paralelas e perpendiculares, remete à lógica das cidades insulares portuguesas, como descreve Manoel Teixeira e Margarida Valla: "o núcleo de ocupaçăo primitivo implantavase em um local com boas condiçóes de defesa e boas condiçóes como poro natural, e a primeira rua, que viria a tornar-se a principal, acompanhava a conformidade da bara. A estrutura de ocupaçăo que daí resultava era essencialmente linear. Numa fase subseqüente, desenvolveu-se uma ou duas ruas, paralelas à primeira e à curta distância desta para o interior. Apoiando-se nesses eixos estruturais e fundamentais, construilu-se perpendicularmente a eles algumas ruas transversais de pequenas dimensōes que

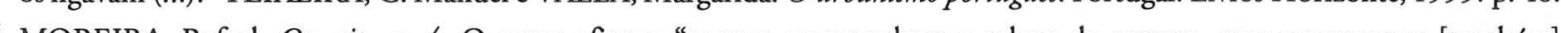
MORERA, Rafal. Op. cit., p. $4 . O$ autor afrma: "as Tuas acompanham o relevo do terreno, mas procuravam [também] por transversais (...)" Idem. p. 5.

${ }_{17}$ ROSSA, Walter. “A cidade portuguesa”. In: PEREIRA, Paulo.(org.) Historia da arte portuguesa. Barcelona: Círculo de Leitores, 1995. p. 254. v 3. 
ço espacial dos largos claramente percebida se comparadas as volumetrias das duas igrejas com os demais edifícios que as circundavam e delimitavam: esses, formados por uma unidade compacta e predominantemente horizontal, ao se relacionarem às duas igrejas, evidenciaram os seus contrastes volumétricos e estabeleceram uma clara relação entre os edifícios profanos e os religiosos, confirmadora do poder e papel simbólico dessas arquiteturas na estrutura geral do povoado.

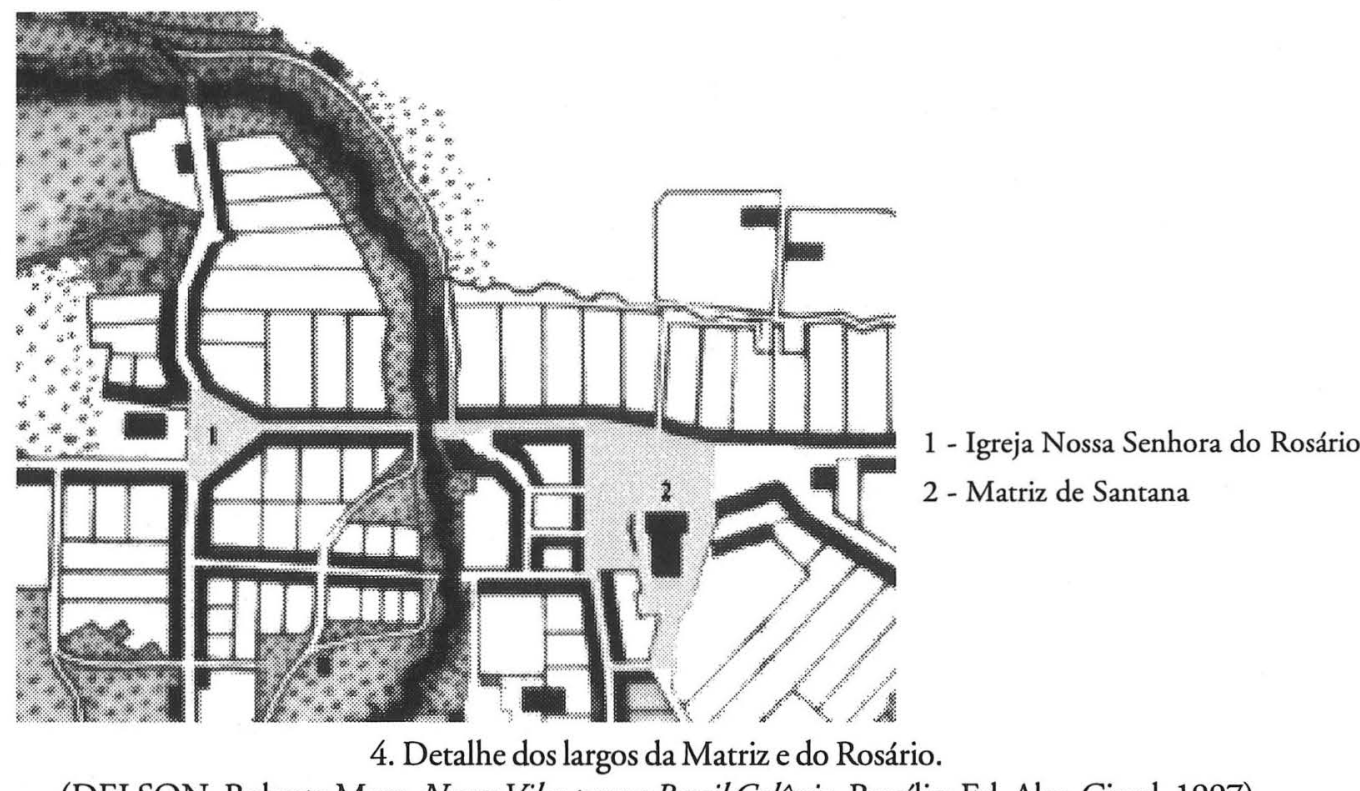

(DELSON, Roberta Marx. Novas Vilas para o Brasil Colônia. Braślia: Ed. Alva-Ciord, 1997)

Concomitantemente a essa concepçáo de destaque de edifícios, os largos também contribuíram. Suas formaçốes em locais proeminentes asseguraram a evidência das igrejas que se ergueram neles como unidades soltas em acrópole, voltando-se para ruas e estradas e adquirindo forte autonomi volumétrica na paisagem da cidade. De seu lado, a escala monumental dos edifícios reforçou a imagem o sentido da importância dos largos, marcando neles o seu valor em relação aos demais edifícios.

Do ponto de vista espacial, essa concepção procurou uma associação da lógica do sistema de ruação à lógica do sistema de implantação das igrejas, permitindo uma configuraçăo na qual essas compareciam sempre soltas, separadas do casario e com relativa independência da estrita funcionalidade do traçado das ruas.

Em Santana, o Largo da Matriz foi o elemento fulcral de todo o arraial, o grande espaço central e de maior dinamismo, onde se organizaram a igreja principal e as residências das pessoas mais importantes, como aponta o prospecto de $1751 .{ }^{18}$ Essa distribuição configurou uma ordenação geométrica e simbólica, com nítidas distinçôes espaciais entre os lugares sagrados, coletivos e individuais, que também se revelaram nos valores de proporção e dimensão da Matriz e das relaçốes que a sua nave estabeleceu com o largo, demonstrando e marcando a importância de cada um e o tipo de integraçáo que se firmou entre os espaços interno e externo.

${ }^{18}$ Segundo esse prospecto, moravam nesse largo: o capitāo de Dragōes, o capitâo-mor da vila, o fiscal da Intendência, o escrivāo Pun Nore Universidade de São Paulo, 2000. p. 235.

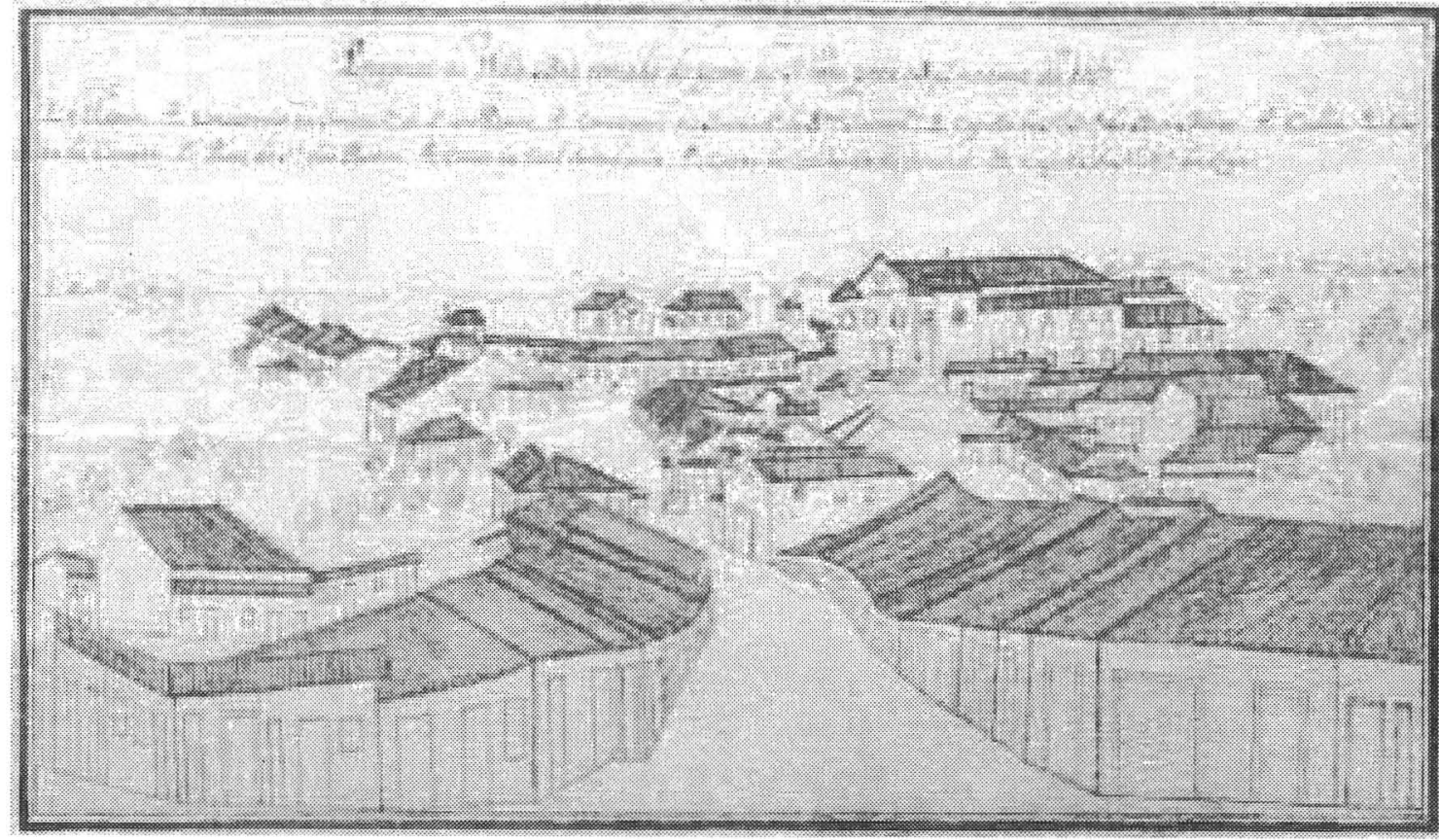

5. Prospecto de 1751 de Vila Boa de Goís

(REIS GOULART, Nestor. Imagens de vilas ecidades do Brasil Colonial. São Paulo: EDUSP, 2000)

Quanto ao Largo do Rosário, o segundo espaço amplo do arraial de Santana, esse desenvolveuse em frente à antiga Igreja dos Pretos, no ponto onde convergiam os caminhos que chegavam de Meia Ponte e o do antigo Arraial da Barra, e abrigou, em sua área, a maior concentração de população parda e forra. De pequenas dimensões, com formato irregular, orientou-se em direção à Rua Direita, revelando, em suas estruturas, nítida relação de subordinaçáo com o Largo da Matriz, reforçada pelo Rio Vermelho que, situado entre os dois largos, estabeleceu para o arraial uma barreira física e social.

Em sua parte mais alta, dominando todo o conjunto, localizou-se estrategicamente a antiga Igreja Nossa Senhora do Rosário dos Pretos. ${ }^{19}$ De proporçôes màis modestas que a Matriz, sua "monumentalidade" foi reforçada pelo seu deslocamento para um dos lados, aparentemente em busca de uma melhor visáo da Rua Direita, que se desenvolveu à sua frente.

Com esses dois largos e suas respectivas igrejas, o Arraial de Santana, embora pequeno, estruturou, portanto, um espaço marcado por edifícios religiosos dispostos hierarquicamente e que mantiveram um claro diálogo entre si: a matriz, altiva, virada para a estrada, dominou o conjunto e orientou a implantaçáo da Igreja Nossa Senhora do Rosário que, voltada para o Largo da Matriz, manteve uma ordenaçáo espacial disciplinar, reforçando o respeito ao espaço fundacional.

$\mathrm{Na}$ articulação dos largos com os demais elementos urbanos, pode-se então observar que ambos se desenvolveram ao longo do principal eixo de fundaçáo, onde se encontram dispostos os acessos de entrada (pelo Largo do Rosário) e saída da Vila. ${ }^{20}$ Próximas a esse eixo, pequenas ruas

19 A Igreja Nossa Senhora do Rosário dos Pretos foi demolida no início do século XX

${ }^{20} \mathrm{O}$ acesso de entrada é feito pela Rua da Cambaúba, próxima ao Largo do Rosário, e o de sá́da, pela Rua Direita que, m. atravessando o largo da Matriz, segue paralelamente o Largo do Chafariz e transforma-se novamente na estrada que alcançava 
formaram-se paralela e perpendicularmente, apenas a Rua Direita, numa curta distância, coincidindo com o eixo para voltar depois a ser estrada. Assim, nessa disposição, a partir de um elemento estruturador de ruas e largos, o Arraial pôde adquirir seu aspecto linear com espaços pontuados por igrejas.

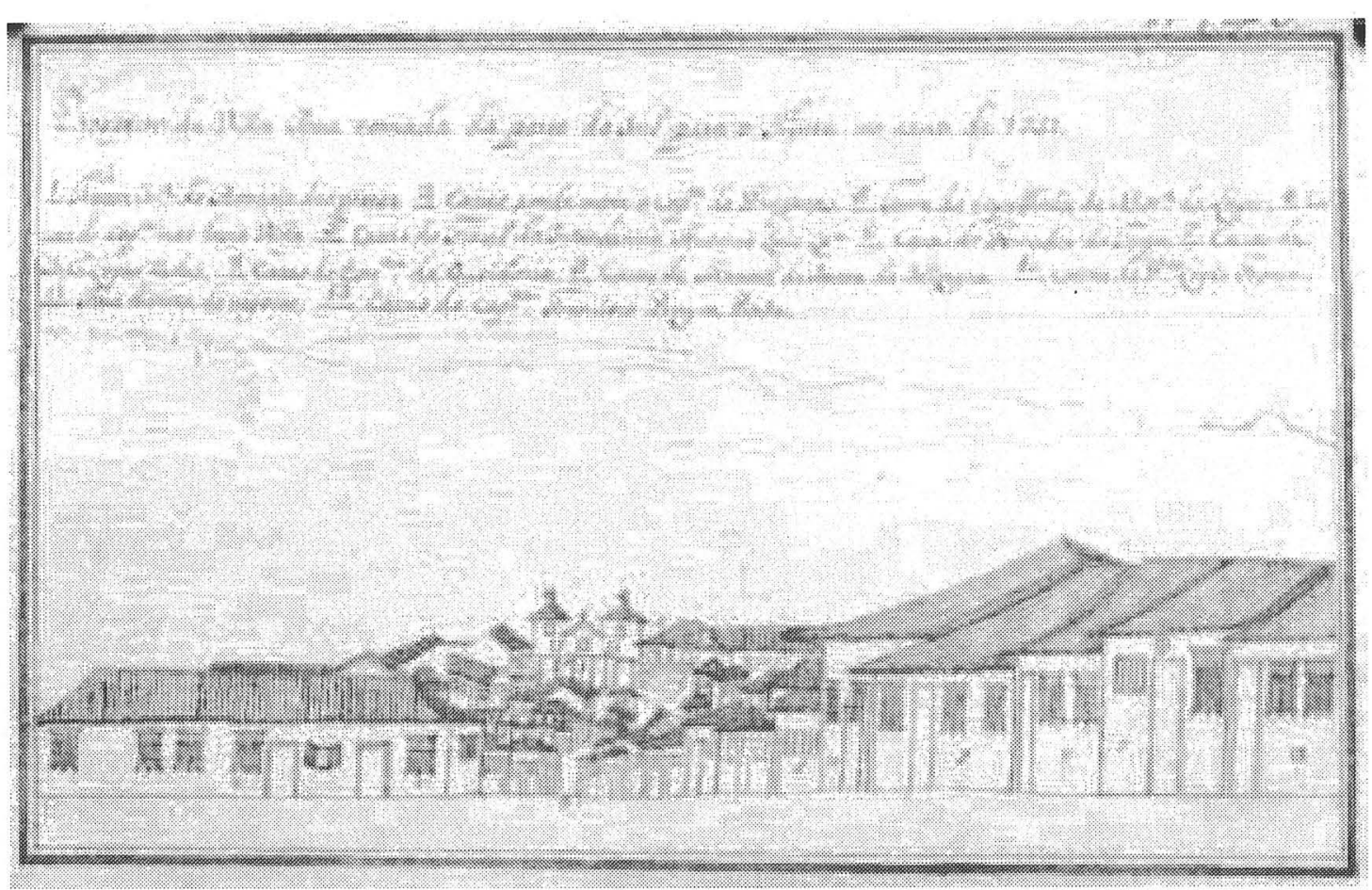

6. Prospecto de 1751 de Vila Boa de Goiás.

(REIS GOULART Nesto. Tropens de vilhs ecidades do Brasil Colonial. São Paulo: EDUSP, 2000)

Cabe lembrar também que esse tipo de organização, que priorizava a arquitetura religiosa, contava com a figura do cordeador ou arruador, ${ }^{21}$ oficial que trabalhava em contato direto com a realidade topográfica e de sensibilidade atenta à arquitetura das igrejas. A lógica do seu trabalho estava diretamente associada às escalas dos edifícios e partia do particular para o geral, orientando-se pelos eixos físicos e visuais de formação do núcleo, para adotar medidas vinculadas às proporçốes do local. Observaçáo e olhar aguçados foram suas qualidades básicas e, com sua corda, buscou uniformidade no alinhamento dos edifícios da rua. A rua foi seu maior referencial, considerada eixo estruturador do povoado para os edifícios que se elevaram ao longo de seu percurso, estabelecendo a articulação necessária entre arquitetura e espaço urbano e conferindo à cidade maior unidade.

${ }^{21}$ Emparelhado ao arruador encontra-se, desde o início, a figura do mestre de campo. Assim, diante do documento abaixo, cabe conjeturar se, em muitos aspectos, as atividades desses dois profissionais náo coincidiam.

conjeturar se, em muitos aspectos, as atividalas
"Para a consulta do governo dos Goyases (...)

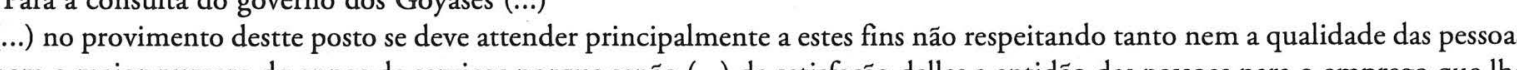
deve dar (..) mas năo sendo este meraços porque senăo (...) da satisfaçăa delles a aptidāo das pessoas para o emprego que lhe gente solta e não militar e os estabelecimentos e formatura de minas novas e assim lhe parece votar em primeiro Lugar $p$. Mestre de Campo (...) das Minas de Goyases era o Mestre de Campo Jöao Ferreira Tavares pela grande practica que tem da Minas e de mineiros e dos certóes ao queridaem 14 annos de assistencia das Minas dos Campos Geraes com o postto de Tenente geral várias expediçoes, que nellas tem feito para evitar descaninhos, e socegar tumultos que sao (...) communs (...) 1731 , março, 30 . Histórico Ultramarino - Goiás, Cx. 1, D2, Lisboa.
Sobre a lógica da intervenção do cordeador, responsável pela estruturação física dos núcleos urbanos coloniais, Bittencourt comenta:

Deve-se pensar, também, na rua ou no arruamento, onde o encadeamento lógico da organizaçâo espacial nasce do particular, não sendo a mesma visáo da cidade completa, encontrada nos tratados da chamada cidade ideal do Renascimento, onde até os limites estâo definidos geometricamente pelo traçado de muralhas, mas também não é igual às soluçōes medievais, onde a rua surge como resultado da agregação entre edifícios sobrepostos lado a lado. Quando se tem um desenho preliminar (projeto) da cidade como um todo, a forma das quadras é o princípio espacial basilar na estruturaçáo dos espaços. Assim, as ruas aparecem com claro vínculo formal, derivado do formato de quadras. A cidade portuguesa do século XVII tem tradicionalmente a rua como elemento estrutural de sua ordenação, ficando impossível sua compreensão, tomando-se com referência modelos originados de uma concepção espacial que se encaminha do geral para o específico. ${ }^{22}$

Assim, as ruas e a localizaçáo privilegiada dos edifícios religiosos de Vila Boa em terraplenos elevados ou esquinas não só realçaram o seu caráter sacro e o seu destaque dentro da cidade, mas também, conforme mostram os prospectos de 1751 , proporcionaram às igrejas eficazes efeitos de monumentalidade e unidade, convergindo o olhar do espectador para as múltiplas visadas que the eram oferecidas. Junto a esse tipo de valorizaçáo, também um outro recurso alcançou o mesmo fim: o do deslocamento das igrejas em relação aos demais edifícios circundantes, como o que se vê no deslocamento frontal da Igreja do Rosário, que permitiu a maior independência desse edifício em relaçáo ao casario que se desenvolveu ao seu redor.

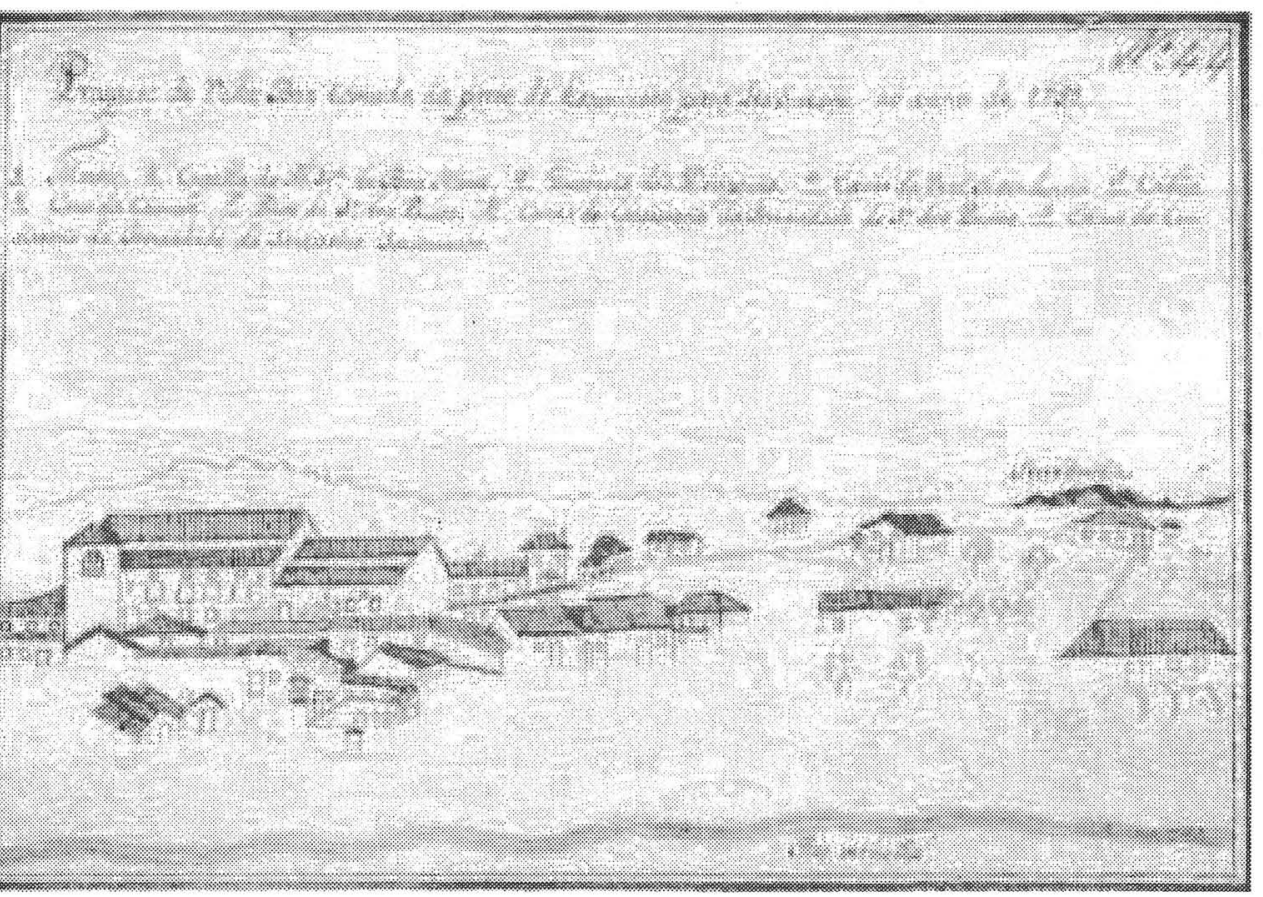

7. Prospecto de 1751 de Vila Boa de Goiás.

(REIS GOULART, Nestor. Imagens de vilas e cidades do Brasil Colonial. São Paulo: EDUSP, 2000)

22 BITTENCOURT, Luiz Cláudio. Regularidades do visivel. Tese de Doutorado. São Paulo: FAUUSP, 1999. p. 106 
Com essa concepçáo, na qual o edifício religioso é erguido como unidade solta, em locais íngremes, que permitem a formaçáo de largos que buscam articulação entre si, alcançou-se o pretendido efeito de visibilidade das igrejas do antigo Arraial de Santana, bem como sua adequada integraçáo a um sistema urbano português na sua mais tradicional forma de fazer cidades.

\subsection{UMA NOVA CONCEPÇÃO ESPACIAL: VILA BOA DE GOIÁS}

A criaçáo da capital dos Goyazes inseriu-se no âmbito de uma intensa política urbanizadora de Portugal, ${ }^{23}$ cujo principal objetivo foi a definitiva ocupaçáo das terras brasileiras e as rigorosas delimitaçóes de suas fronteiras com a Espanha. Essa política implicou a criaçáo de novas vilas e a relocação de vários outros núcleos populacionais. Nos novos casos, houve alteraçóes nas formas de implantaçáo de matrizes e formaçáo de espaços urbanos, que foram "concebidos segundo traçados geométricos, a maior parte das vezes ortogonais, onde se expressam[ram] alguns dos grandes temas do urbanismo clássico: a cidade planejada racionalmente na sua estrutura global; a praça como elemento central da malha urbana, e os conceitos de planejamento e de beleza urbana associados à regularidade do traçado, à adoção de modelos arquitetônicos uniformes, aos quais devem[iam] obedecer todas as construções de uma rua, de uma praça ou mesmo de uma cidade". ${ }^{24}$

Nos núcleos antigos, essas inovaçóes manifestaram-se com modificaçóes administrativas e espaciais, com freqüentes preocupaçóes com o reordenamento de traçados.

Porém, tanto nos novos assentamentos quanto nos antigos, essa concepção marcou os espaços com uma nova relaçáo arquitetônica: as igrejas, concebidas anteriormente como unidades singulares e de destaque, reuniram-se com aqueles edifícios que, simbolicamente, representavam o poder estatal e marcaram, no principal local da Vila, a união desses dois poderes. Configurou-se, então, uma outra disposição arquitetônica, na qual a relação entre as volumetrias das construções religiosas e o espaço externo não se fazia mais como nas antigas estruturas do "urbanismo" da primeira fundaçáo. Contrariamente, a nova lógica elegeu não só as Matrizes, mas também as Casas de Câmara e Cadeia, para, juntas, serem os focos de atençáo do núcleo urbano.

Nesse contexto, os traçados regulares indicados para as novas vilas, a ênfase no realinhamento de núcleos antigos, a construção de edifícios estatais e religiosos, "a concepção cenográfica do espaço, a valorização das fachadas e a adoção de modelos uniformes aos quais devem obedecer todas as construçốes" ${ }^{\text {25 }}$ foram as inovaçóes que marcaram um outro status para os aglomerados urbanos coloniais. Em Vila Boa, esses aspectos estáo apontados em sua Carta de Fundaçáo:

Dom João por graça de Deos Rey de Portugal e dos Algarves da quem e da lem mar em Afric Senhor de Guiné (...). Faço saber a vos Conde de Sarzedas governador e Cappitão general da Cappitania

23 "Este projeto urbanizador era um componente fundamental da estratégia de efectiva ocupaçăo do território. Por um lado, Por outro lado, através da fundaçáo de novas vilas e cidades ou da mais simples e pragmática refundaçăo de aldeamentos missionários, e de sua integraçăo numa rede urbana global, procurava-se a efetiva ocupaçăo territorial do Brasil”. TEIXEIRA, Manuel C. e VALLA, Margarida. Op. cit., p. 254

${ }^{24}$ Idem. p. 253

${ }^{25}$ Idem. p. 256 de São Paulo que Eu sou servido por resoluçáo de 7 deste presente mês e anno em consulta do meu Conselho Ultramarino passeis às minas dos Goyazes e nellas determinei citio mais a proposito para huma Villa e procureis que seja o que parecer mais saudavel e com provimento de boa agoa e lenha perto de algum Arrayal que se ache já estabelecida para que os moradores delle possam com mais comodidade mudar a sua habitaçăo para a Villa, logo que determine y nella o lugar da praça no meyo dá qual se levante o Pelourinho, e se assignale a area para edificio da Igreja, capaz de receber competente numero de fregueses ainda que a povoaçáo se aumente, e que façaes delinear por linhas rectas a area para as cazas com seus quintaes, se designe lugar para se edificarem a Caza da Camara e das audiencias e Cadeia, e mais officinas publicas que todas devem ficar na area determinada que as cazas dos moradores, as quaes pello exterior sejam todas no mesmo perfil ainda que $\boldsymbol{o}$ interior as fará cada hum dos moradores à sua feiçăo de sorte que em todo o tempo se conserve a mesma formosura da terra, e a mesma largura das ruas e junto da Villa fique bastante terreno para logradouro publico, e que nelle se poderem edificar novas cazas, que serão feitas com a mesma ordem e concerto com que se mandam fazer as primeiras, e deste ou se não poderá em nenhum tempo dar de sesmaria, ou aforamento, parte alguma sem ordem minha que (...) esta; e os governadores poderão repartir em sesmaria todas as mais terras com as clauzulas, e condiçoens com que se dão as mais no Brazil excepto na extenção de terra que se costuma dar a cada morador porque nos contornos da ditta Villa dentro em seis legoas de distancia della se não poderá dar a cada morador mais do que meya legua de terra em quadro; porem à mesma V. se dara huma datta de quatro legoas administrarão os officiais da Camara para do seu rendimento se fazerem as obras e despezas do Conselho desta terra poderáo aforar para o mesmo effeito aquellas partes que lhes parecer, observando o que despoem a ordenaçăo que estes aforamentos fora das dittas seis legoas, se daram as terras por sesmarias na forma que se (...) nas mais terras do Brazil (...) El Rey Nosso Senhor o mandou pellos. D. Joze de Carvalho Abreu e Joăo de Souza, (Conselheiros do Conselho Ultramarino, se passou por duas vias. Antonio de Souza Pereira a fez em Lisboa Occidental a 11 de fevereiro de 1736 - Documento para marcaçăo de Vila Boa de Goiás. ${ }^{26}$

$\mathrm{Na}$ carta, as novas indicações para a implantaçáo da Vila diferenciam-se notoriamente da anterior estrutura do Arraial de Santana, formado, como se viu, a partir de eixos definidos por ruas, largos e edificações religiosas que se destacavam. O princípio de formação urbana já não foi mais o de pólos lineares, mas o de marcação de uma praça central, onde deveriam ser erguidos a Matriz de Santana e os edifícios institucionais representantes dos poderes eclesiástico e estatal, conforme também se pode ler no documento a seguir:

O Sr. D. Luiz de Mascarenhas sucedeu no governo de São Paulo, e (...) encaminhou-se a Goiás com grande comitiva de oficiais militares em 25 de julho de 1739; demarcou o lugar da vila que veio criar, a que chamou de Vila Boa de Goiás, em atençáo a Bueno seu descobridor e ao gentio Goyaz; fez erigir o pelourinho, designou o lugar da praça, da matriz, da cadeia e dos edifícios principais, e não se dedignou de pegar na ponta da corda e servir de peáo para se marcarem os logradouros públicos: ${ }^{27}$ estabeleceu o senado, e escreveu ao superintendente Agostinho Pacheco Telles para eleger

${ }^{26}$ Arquivo Frei Simāo Dorvi. Documento avulso, fls. 106,107. Cidade de Goiás.

${ }^{27} \mathrm{O}$ arruador podia ser um engenheiro, um funcionário administrativo, um governador, etc. Arruar era o ato de desenhar no território podia ser um engenheiro, un furimato administrativo, um governador, ecc. mas com as potencialidades de reflexăo e adaptaç̃o à realidade que o desenho permirisec. 
dous vereadores e procurador do conselho, os quaes foram eleitos e tomaram juramento, fazendo a sua primeira vereança no primeiro de agosto de $1739 .{ }^{28}$

Tais documentos confirmam as noçôes de regularidade, bastante presentes na época, mas também a inclusão de Vila Boa no conjunto de uma política urbana mais abrangente, semelhante aos Autos de Fundaçóes da Capitania do Rio Negro, de 1755, ou da Vila Bela da Santíssima Trindade do Mato Grosso, de 1741, dentre outros. ${ }^{29} \mathrm{O}$ que significa a existência de "um conjunto de princípios estabelecidos que foram sistematicamente utilizados na definição de traçados destas novas fundaçốes, resultados de uma prática efetiva de urbanização e de princípios teóricos que simultaneamente se desenvolviam. Nalguns casos, a realidade construída acabava por diferir das prescrições enunciadas nestes documentos devido a alterações introduzidas localmente, muitas vezes motivadas pela particularidades do sítio e pelo confronto com a realidade."”o

Essas inovaçóes estão implícitas na expressão formosura da cidade, o que Manuel Teixeira e Margarida Valla interpretam como importantes indicadores de regularidade de traçado e de uniformidade para os diferentes tipos de construçōes dos novos espaços. Com essas indicaçóes, que envolvem inclusive o significado da palavra formosura, garantiram-se aspectos de uma concepção alinhada às soluçóes formais mais clássicas, integradas ao cientificismo setecentista, à profusão da cultura tratadística e articuladas ao espírito pragmático português.

A associaçáo da expressáo "formosura da cidade à regularidade do traçado e à arquitetura uniforme a que várias construçóes deviam obedecer" ${ }^{31}$ clareia como a fundaçáo das novas vilas se relacionava com procedimentos que envolviam maior planejamento e não apenas normas gerais para a construção de edifícios públicos. No caso de Vila Boa de Goiás, essas indicaçôes vieram acompanhadas de planos arquitetônicos para a Matriz de Santana e a Casa de Câmara e Cadeia. ${ }^{32}$

A criação de novas vilas no século XVIII caracterizou-se, portanto, pelas construçóes de novo edifícios institucionais e traçados regulares, organizados em torno de praças situadas nas regiōes centrais de sítios urbanos. Ruas e quarteirōes também se formaram a partir de estruturas lineares, compostas por eixos ortogonais articulados às praças localizadas estrategicamente e pensadas como centros de orientação espacial, funcional e simbólico, como enfatizam Manuel Teixeira e Margarida Valla:

para além de ser praça em que se continuam a localizar os principais edifícios institucionais de caráte religioso e civil a importância deste espaço para a estruturação da cidade advém também, e sobretudo, das próprias características formais, que a tornam o elemento central e gerador da malha urbana. ${ }^{33}$

${ }_{28}$ SILVA E SOUZA, Luiz Antônio da. Memória sobre o descobrimento, governo, populaçäo e coisas mais notáveis da Capitania de Goid́s Goiânia: Ed. Oriente, 1978.p. 85.

29 Especificamente no trecho da carta régia de Fundaçäo da Capitania do Rio Negro, de 3 de Março de 1755, encontram-se
princípios iguais aos da Carta de Fundaçáo de Vila Boa de Goiás. Apud.TEIXEIRA, Manuel eValla, Margarida, Op.cit,p. 256 ${ }_{30}$ TEIXEIRA, Manuel C.e Valla, Margarida. Op.cit, p. 255

${ }^{31}$ Idem. p. 256

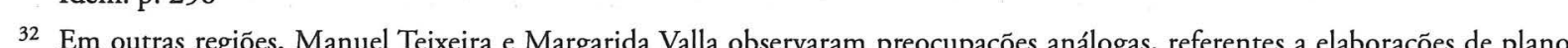
para esses tipos de edifícios. «(..) Para a construçāo de Casas de Câmara e Cadeias condignas, segundo o gonaçoes de planos para esses tipos de edificios. "(...) Para a construçáo de Casas de Câmara e Cadeias condignas, segundo o governador Manu
Bernardo de Melo e Castro, "será bom levar algum Risco feito por pessoa intelligente". O mesmo se passava com as igrejas, para as quais se elaboravam projetos "a cuja imitaçăo se erigiräa todas as mais egrejas

${ }^{33}$ Idem. p. 257
E quanto aos antigos núcleos adaptados, a praça deveria assumir "um papel aglutinador e gerador do espaço urbano, papel que tradicionalmente as praças não detinham nos traçados urbanos portugueses". ${ }^{34}$

Dessa maneira, na história da formaçáo urbana de Vila Boa, a demarcaçáo do Largo do Chafariz pode ser entendida como uma grande intenção de inovação espacial, planejada para assumir o papel gerador da malha urbana, opondo-se à concepçáo anterior, do Arraial de Santana, que fazia caber particularmente às igrejas a maior responsabilidade pelas ordenaçóes espaciais. A pretensáo foi a de organizar os espaços da Vila em funçáo do novo centro, onde se fixariam os edifícios de representaçáo eclesiástica e estatal e, nessa perspectiva, a arquitetura da igreja não se apresentaria mais como o principal elemento de ordenaçáo, mas como um dos vértices de um espaço tensionado entre o sagrado e o profano.

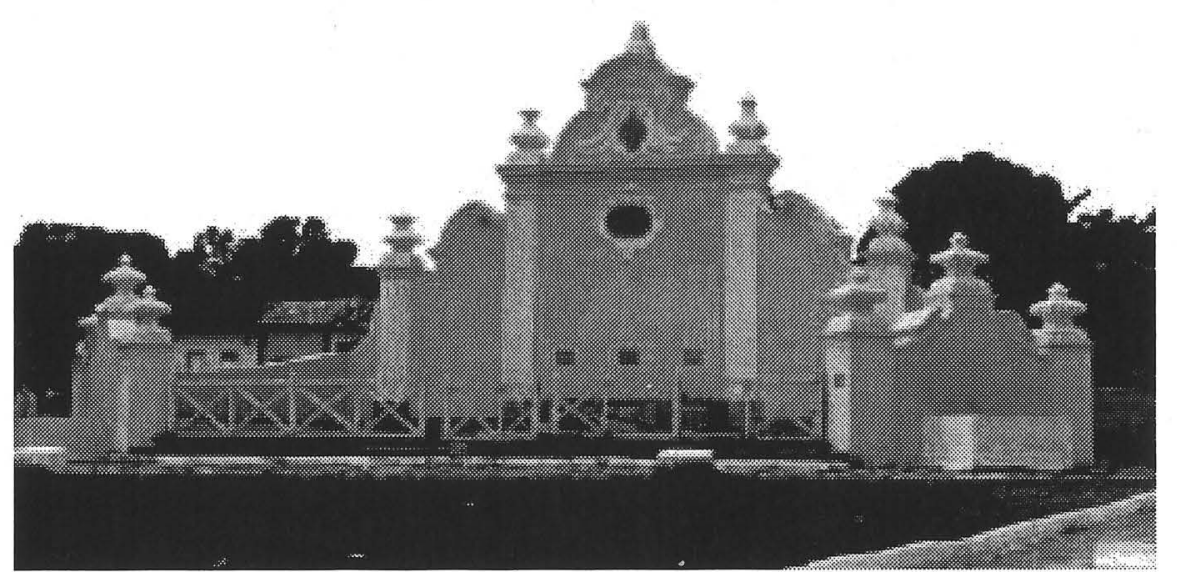

8. Largo do Chafariz. (Foto de Deusa M. R. Boaventura)

No entanto, para além dessas pretensóes, o espaço real de Vila Boa revelou significativas distorções em relação ao seu plano, com marcas resistentes da tradicional concepção do Arraial de Santana, como se pode ler nesta nota de um ouvidor da época:

E devendo-se nesta Vila, como Capital da referida Capitania estabelecer este interessante sistema praticado em todas as naçốes mais polidas da Europa - para que náo grasse para o futuro a irregularidade com que pelos primeiros habitantes foi estabelecida, remete a V. M.(sic.) por escrito as Condiçōes que tanto por utilidade da República como do serviço de Sua Majestade se devem observar daqui em diante na edificação e reedificação de qualquer Edifício que haja de construir-se, ordenando a V. M. que $(\ldots . .)^{35}$

${ }^{34}$ (...) Nas cidades construídas até entâo, quer em Portugal quer no Brasil, mesmo naquelas cidades que adotavam um plano regular, muitas vezes a praça năo tinha uma ordenaçăo regular à partida. Ainda que fundamental na estruturaçắo da cidade, pelo e as funçoes institucionais mais importantes, a regularidade formal da praça ia-se obtendo gradualmente, fruto de múltiplas intervençōes. A importância da praça advinha fundamentalmente dos edifficios que nela se localizavam". Idem, Ibidem. ${ }^{35}$ Carta ao Ouvidor da Câmara com as instruç̧̄es recomendadas à Câmara na Audiência Geral. Apud: BERTRAN, Paulo. Op. cit 
Esse documento revela a persistência e o predomínio de sistemas e práticas urbanas mais antigas, até pelo menos as do tempo das intervençôes de Cunha Menezes. Dessa forma, Vila Boa, mesmo na categoria de capital, manteve uma configuração espacial onde o antigo Largo da Matriz fixou-se definitivamente como o ponto mais central e dinâmico da cidade, com o novo Largo, o do Chafariz, submetendo-se hierarquicamente a ele. Na verdade, a Vila firmou-se mais administrativa do que fisicamente, com parte de suas funçōes e a matriz permanecendo no arraial e, consequentemente, mantendo a estrutura anterior, junto a outras do novo espaço fundacional, como a Casa de Câmara e o pelourinho. Entretanto, mesmo sem a plena transformaçáo das novas estruturas urbanas, as poucas mudanças físicas inauguraram um espaço predominantemente diversificado e de maior complexidade funcional, onde o Largo do Chafariz e o da Matriz rivalizavam entre si quanto à capacidade de abrigar as atividades religiosas, político-comemorativas, comerciais e punitivas que, anteriormente, conviviam no mesmo cenário.

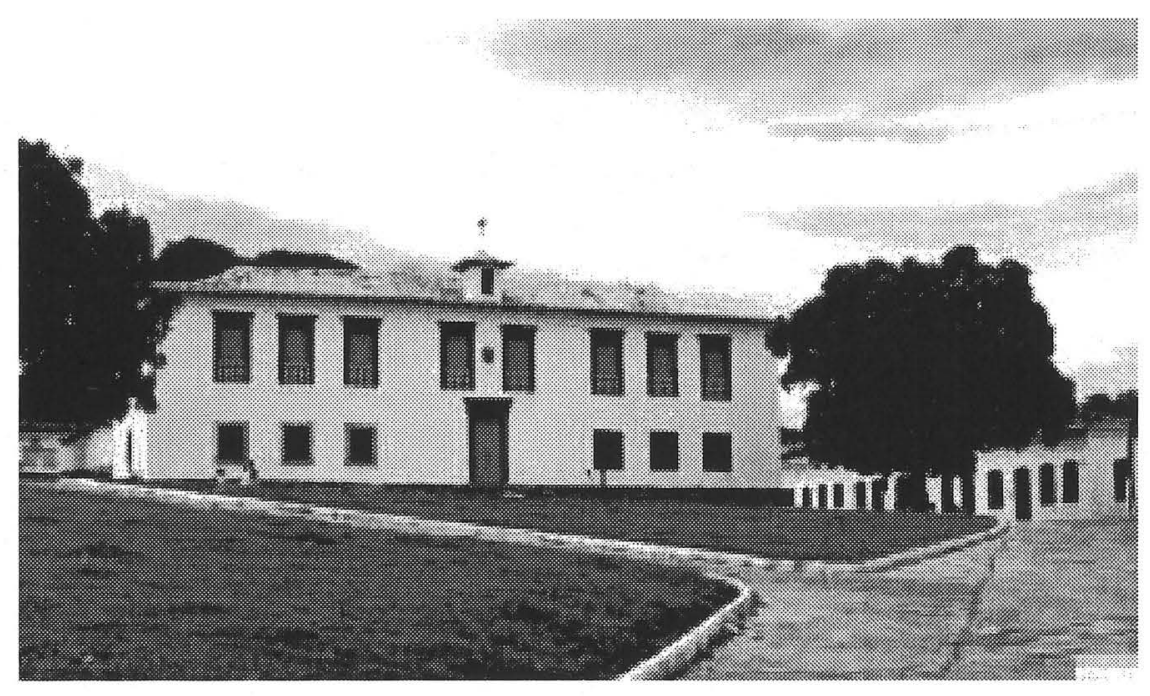

9. Antiga Casa de Câmara e Cadeia de Vila Boa de Goiás. (Foto de Deusa M. R. Boaventura)

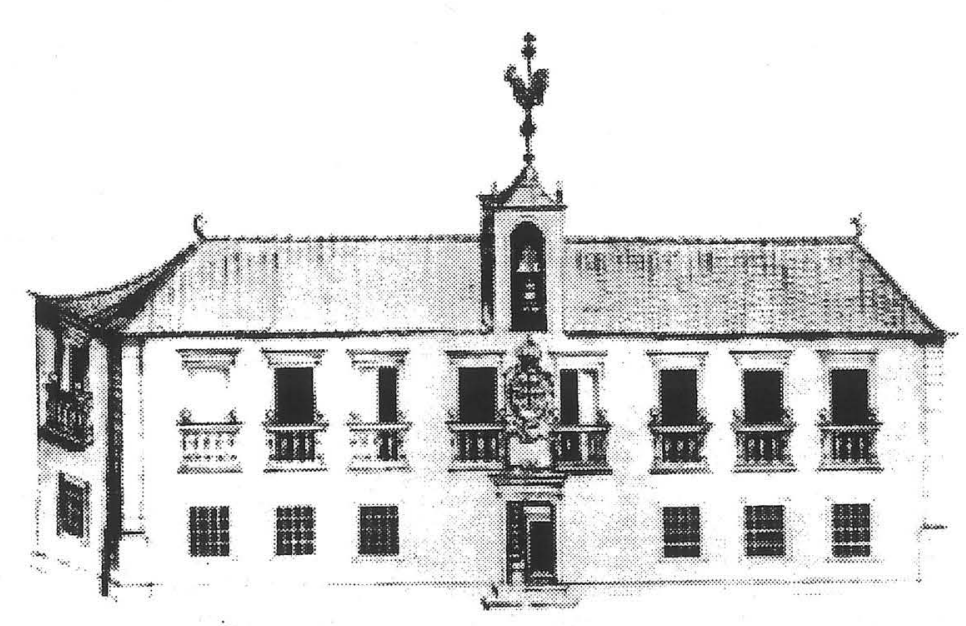

10. Projeto original da antiga Casa de Câmara e Cadeia de Vila Boa de Goiás (Arquivo SPHAN/Pró-Memória)
1.4 AS REFORMAS URBANAS NA SEGUNDA METADE DO SÉCULO XVII

A resistência em aceitar novas estruturas para a constituição de uma capital é revelada pela continuidade da Matriz no antigo local da capela de Santana, pelo desrespeito ao traçado da nova praça, pela determinaçáo dos habitantes em não transferirem suas residências para a área delimitada à expansão da Vila e por observaçóes feitas em documentos de 1749, quando o Ouvidor Geral da Capitania e Corregedor Especial da Câmara de Vila Boa ainda bradava aos ecos surdos para que se consentisse a construção de "casas [apenas] para a parte da Vila e do Pelourinho e casa da Câmara della, e que os mais se impediriam e que sendo preciso demandarião demolir a quem intentasse nova edificaçáo para a parte do Rosário com já havia proibido". ${ }^{36}$

Entretanto, essa mesma resistência foi alvo para a implementaçăo das reformas urbanas propostas pelo governador Cunha Menezes, quando a Vila passou a orientar-se pelos princípios da regularidade, através da elaboração do plano de realinhamento de 1782 e do Código de Posturas Urbanas. ${ }^{37}$ De acordo com Paulo Bertran, com o plano,

tentou-se coibir a invasão ou apossamentos de terrenos públicos, murados por particulares, bem como a concessão de chácaras, que doadas pela Câmara da Vila, ameaçavam impedir a expansão ordenada. Foi esse o momento de abertura de extensas ruas como as do Passos da Pátria e da capela Santa Bárbara. Do lado sul, planejou-se os traçados das Ruas Ernestina (Travessa Aurea) e da rua Hermógenes Coelho, atual Rua Nova Luziânia. Para todas estas modificaçōes e expansōes, o governador Luís da Cunha providenciou, também em 1782, o levantamento [dos edifícios] com toda a ocupaçáo da cidade e marcaçáo de ruas existentes e planejadas, lotes e chácaras. ${ }^{38}$

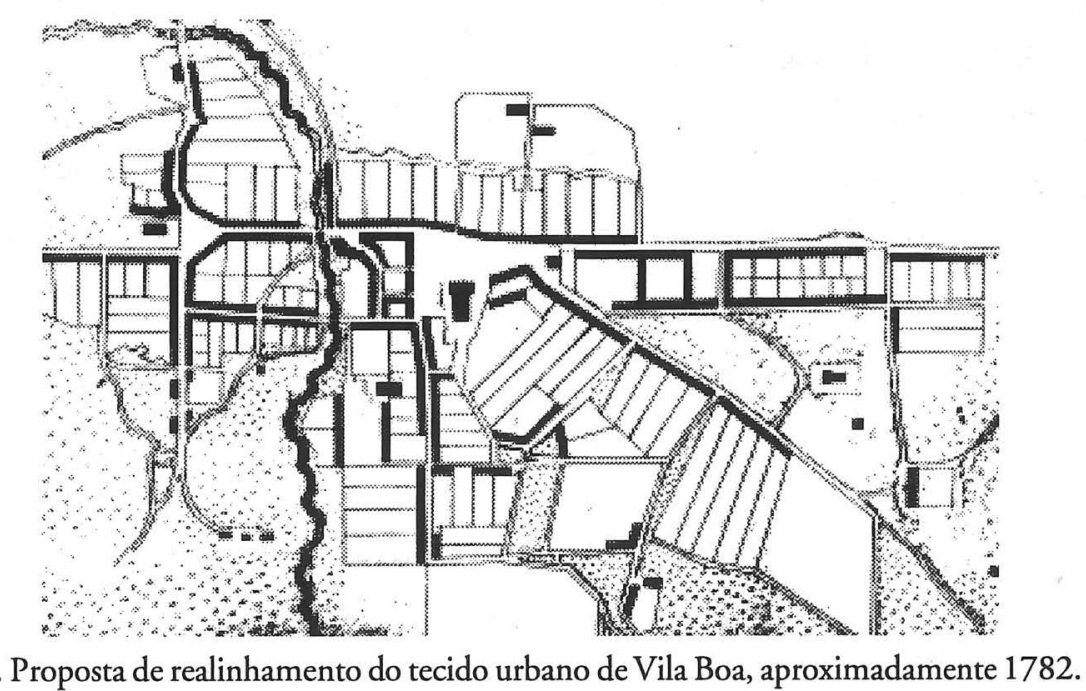

(REIS GOULART, Nestor. Imagens de vilas e cidades do Brasil colonial. São Paulo: EDUSP, 2000)

$\overline{{ }^{6}}$ Apud: BERTRAN, Paulo. Noticia geral da capitania de Goiás. Op. cit., p. 50

37 "Sendo-me encarregado pela Rainha Fidelíssima Nossa Senhora o governo desta Capitania năo só pelo que pertence à boa administraçāo da Justiça e conservação dos seus Vassalos, mas também ao Aumento das povoaçóes de que elas se compōem, seus edifficios, para que debaixo do preceito de alinhamento formem um agradável prospecto e consequientemente subam ao maior auge da Polícia e civilidade, de que tanto depende a conservaçăo da sociedade civil. Carta ao ouvidor da Comarca com as instruçóes acima para as deixar recomendadas à Câmara na audiência Geral". Apud: BERTRAN, Paulo. Idem, p. 59. ${ }^{38}$ Idem. p. 50. 


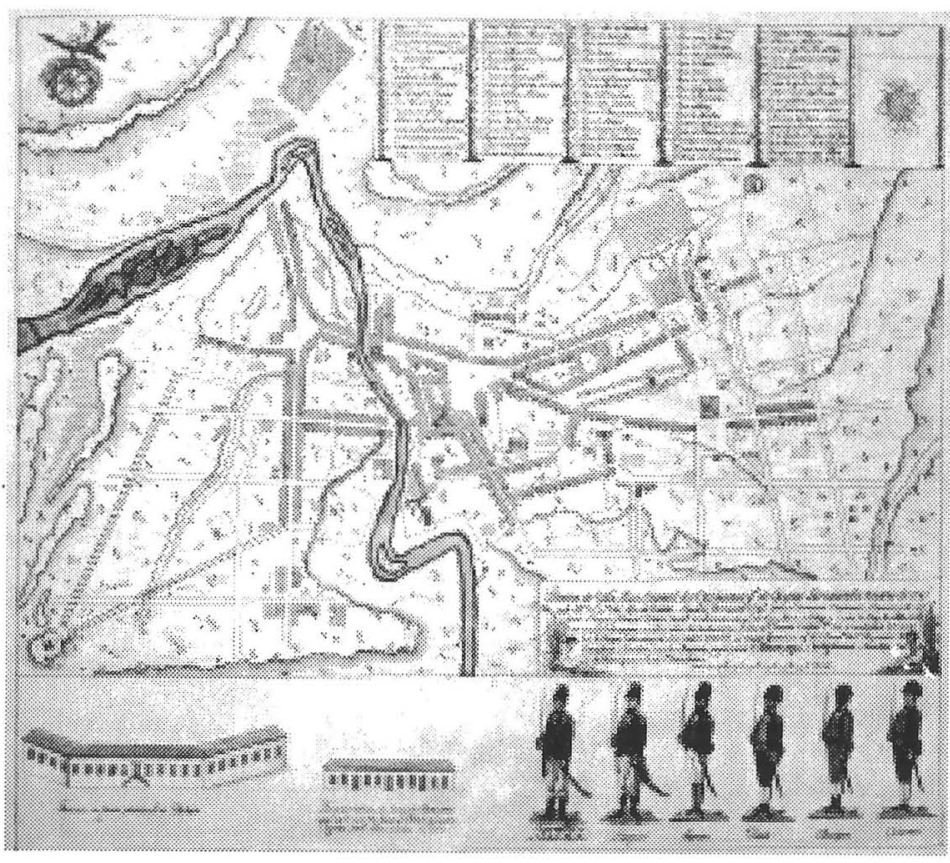

12. Plano de expansão de Vila Boa de Goiás, 1782.

(REIS GOULART, Nestor. Imagens de vilas ecidades do Brasil colonial. São Paulo: EDUSP, 2000)

Com as iniciativas desses governadores, iniciaram-se as maiores transformaçôes espaciais de Vila Boa, com reformas que previram não só o alinhamento da estrutura anterior, como também a melhoria do acesso à Igreja Santa Bárbara e a inserçáo da Igreja de Nossa Senhora do Carmo em uma quadra.

Assim, nessa segunda metade do Setecentos, Vila Boa ficou marcada por resistências, intençóes, reformas e a construção de maior número de capelas, como as de São Francisco de Paula (1761), Nossa Senhora da Boa Morte (1762), Nossa Senhora do Carmo (meados do século XVIII), Nossa Senhora da Lapa (1749) e Santa Bárbara (1775). Nossa Senhora da Abadia (1793) e Nossa Senhora das Barracas (1793), apesar de terem se erguido depois das reformas urbanas de José de Almeida e Cunha Menezes, mantiveram a aparente lógica da implantaçâo das primeiras igrejas, destacando-se pelos seus volumes soltos do casario e assentamento em áreas privilegiadas. ${ }^{39}$

Além de todas essas capelas e reformas do traçado, que buscavam maior regularidade das estruturas existentes, houve também orientaçóes para a construção de fachadas de casas, que deveriam ser uniformes e regulares, ${ }^{40} \mathrm{a}$ construção de uma loteria, de um açougue, de "uma alameda e passeio público no largo do Chafariz, e para isto se plantaram por ordem as árvores, que depois foram cortadas",

\footnotetext{
39 São poucos os dados e informaçōes sobre as capelas Nossa Senhora da Lapa e Nossa Senhora das Barracas, edifícios que ruíram
tempos atrás.

"Todas as Casas ou Edifficios que de novo se construírem, será pela mesma regularidade das melhores que se acham na dita ru

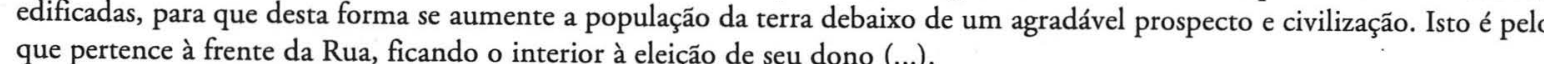
Na Prefa

pintarem as janelas e portas todas de uma cor, para assim suprir a irrima sobre a reedificaçăo, mandarăo os donos das casas Posturas urbanas de Luís da Cunha Menezes. Apud: BERTRAN, Paulo. Op. cite do prospecto com que foram construídas".

${ }^{41}$ TELES, José Mendonça. Op. cit, p. 98-99.
}

a reedificação das três pontes, e, no final do século, a presença de um Jardim Botânico, ${ }^{42}$ que se ergueu segundo um oficio enviado do palácio de Queluz. Nele, lê-se:

Sobre o Jardim Botânico:

Palácio da Guarda 31 de julho de 1799 Off. De D. Rodrigo de Souza Coutinho a D. Francisco de Sousa acusando as informaçóes sobre as árvores em cuja casca se attribuem as virtudes da Quina e da outra (...) cura a hydropesia; sobre a abundancia de salitre na (...) sobre o estabelecimento do terreiro público, sobre a vacina, sobre a criação de correios para Goyaz, sobre o estado das melícias exigindó mappa da população, e que dê incremento ao Jardim Botânico, cultivando, aumentando a cultura da árvore de pão, caneleira, pimenteira, cravos da Índia, café, etc..(...). ${ }^{43}$

Com todas essas iniciativas de reformas e construçóes, inaugura Vila Boa uma nova fase de sua história urbana, que passou a se organizar pelos parâmetros da regularidade. Expressava agora valores bem diferentes daqueles que estavam em jogo no período de implantação do plano. Não se tratava mais de equilibrar os dois poderes, laico e religioso, representados pela Matriz de Santana e Casa de Câmara e Cadeia, mas de exaltar a razão iluminista que, gradativamente, foi se manifestando através de uma maior tendência à regularidade do traçado e das fachadas das construçóes e da presença do passeio público e do Jardim Botânico. Essa lógica passou, então, a ser o princípio norteador das estruturas urbanas da antiga capital, como se vê nas determinaçóes da Coroa:

Igualmente Ordena Sua Alteza Real que V. Sa dê alguns prêmios aos que promovessem mais huma cultura útil, [de árvores] ou nova, e que proponha com as sua luzes, e actividade o que julgar mais conveniente para exercitar esses Espíritos indolentes ainda mais pelo clima, que habitão do que por qualquer outro motivo, e o mesmo Senhor espera que V. Sª Até neste artigo deixara lançadas as raízes de hum grande bem para o futuro (..... ${ }^{44}$

A partir desse momento, com esse conjunto de transformaçóes bastante inovadoras, demarcou-se em Vila Boa a dimensão propriamente pública, ou melhor, assinalou-se nitidamente a dessacralizaçâo do seu espaço. A esfera do sagrado, que antes se confundia com a do profano e se estendia às ruas e largos, ficava agora, fundamentalmente, reservada aos adros e espaços internos das edificações religiosas.

42 "Sobre o Jardim Botânico: (...)

(...) Pelo officio N. 348, e Mappa que o acompanha fica Sua Alteza Real sciente do Estado do Jardim Botânico nessa cidade, e o mesmo Augusto Senhor manda louvar muito a V. $S^{a}$ pelos esforços, com que tem creado, e augmentado o mesmo Jardim, de que para o futuro se hăo de seguir os melhores effeitos, os quaes ainda que a principio sejáo vagarozos, com o tempo, e com o

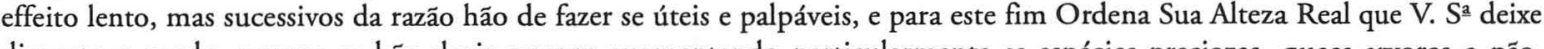
disposto o modo, porque se hăo devir sempre augmentando particularmente as espécies preciozas, quaes arvores a păo, a a V.Sa Palácio de Queluz em 31 de julho de 1799. D Rodrigo de Souza Coutinho". Arquivo da Biblioteca Nacional. Guias de Comunicą̧óes, I, 28, 33. Rio de Janeiro.

(2) ${ }^{43}$ Idem.

44 Idem, Ibidem. 


\subsection{IGREJAS E LARGOS: PERMANÊNCIAS E RUPTURAS}

As práticas urbanísticas adotadas em Vila Boa no século XVIII possibilitaram o predomínio visual dos seus edifícios religiosos em relação à sua paisagem, privilegiando-os com uma certa independência em relaçáo ao casario e ao traçado das ruas, mesmo em casos como o da Igreja Nossa Senhora do Carmo, cuja tradicional implantaçáo foi prejudicada pelas reformas de Cunha Menezes, que a inseriram numa quadra - uma configuração absolutamente nova na história das igrejas vilaboenses.

Aliados da concepçáo que destaca os edifícios como blocos proeminentes, formavam-se, como vimos, largos e adros, os últimos conhecidos como elementos urbanísticos complementares:

Cada um desses espaços tinha a sua própria lógica e a sua expressão formal. Por exemplo, os adros dos Franciscanos tinham uma forma alongada e eram centrados em um cruzeiro em torno do qual se realizavam procissóes. Já os terreiros de Jesus ou pátios de colégios jesuítas eram de forma quadrada ou retangular, dominados pelos edifícios da igrejas, colégio e residência dos padres. ${ }^{45}$

No Setecentos, esses espaços pios destinavam-se ao atendimento dos vários interesses ritualísticos, incluindo as dimensóes laicas, e eram importantes locais de caráter sacro e profano, integrados à estrutura urbana da cidade. Para tanto, suas construçóes deviam atender a normas eclesiásticas e estatais, que condicionavam a escolha dos "locais sacros a céu aberto, a implantação topográfica geral, a trama viária, a significação maior ou menor das parcelas de lote urbano. Os adros foram por muito tempo locais pios, pontos altos de todo o conjunto urbano, de toda a rede de seus espaços internos comuns". ${ }^{46}$

Em Vila Boa de Goiás, as capelas de São Francisco de Paula (1761) e Santa Bárbara (1775) sáo os dois únicos exemplares que possuíram (e possuem) adros formalmente delimitados, provavelmente por se localizarem, respectivamente, num oteiro e numa colina. Esses adros desenvolveram-se com dimensōes reduzidas e participaram do tecido urbano de forma diferenciada: o de São Francisco, próximo ao núcleo central, articulou-se mais diretamente com as vias que conduziam ao Largo da Matriz; e o de Santa Bárbara, mais distante, manteve uma relação secundária com essas circulaçōes, com apenas um único acesso que o ligava ao núcleo da Vila, feito a partir da reforma urbana de Cunh Menezes. Nos dois casos, os destaques urbanísticos das igrejas foram reforçados por esses elementos, que acentuavam sua independência em relação ao traçado urbano.

As demais igrejas de Vila Boa, por não apresentarem adros, relacionam-se diretamente com os largos, não estabelecendo nítidas barreiras físicas entre as dimensóes do sagrado e do profano. ${ }^{47}$ Largos e ruas estruturam-se como espaços de múltiplas funçoes, acolhendo importantes festividades, encontros sociais e manifestações religiosas e populares. Quanto a isso, Murilo Marx afirma que "os adros não apenas proliferam em nossas cidades tradicionais, como se confundem com quase todos os seus largos". 48

\section{$\overline{45}$ TEIXEIRA, Manuel e VALLA, Margarida. Op. cit., p. 219}

${ }^{46}$ MARX, Murilo. Nosso chăo: do sagrado ao profano. Săo Paulo: Editora Universidade de São Paulo, 1988. p. 111.

47 Murilo Marx esclarece a questão sobre o uso dos adros, especificamente sobre o fato de esse espaço exercer também a funçáo

de asilo. MARX, Murilo. Op. cit., p. 125 .

${ }^{48}$ Idem. p. 121.
Um importante exemplo dessa condiçáo é o da Igreja Nossa Senhora da Boa Morte, que se situou na confluência de duas ruas e se voltou para o mais antigo e tradicional espaço da Vila: o largo da Matriz. Sua disposição orientou-se para a Rua Direita que, ao se desenvolver perpendicularmente a ela, permitiu um pleno diálogo com a antiga Igreja dos Pretos. Nessa implantaçáo, o edifício destacou-se de forma solta e isolada em relaçáo ao casario, e a sua visibilidade e independência foram garantidas a tal ponto que ele não ficou prejudicado pelas proporçôes monumentais da antiga Matriz de Santana.

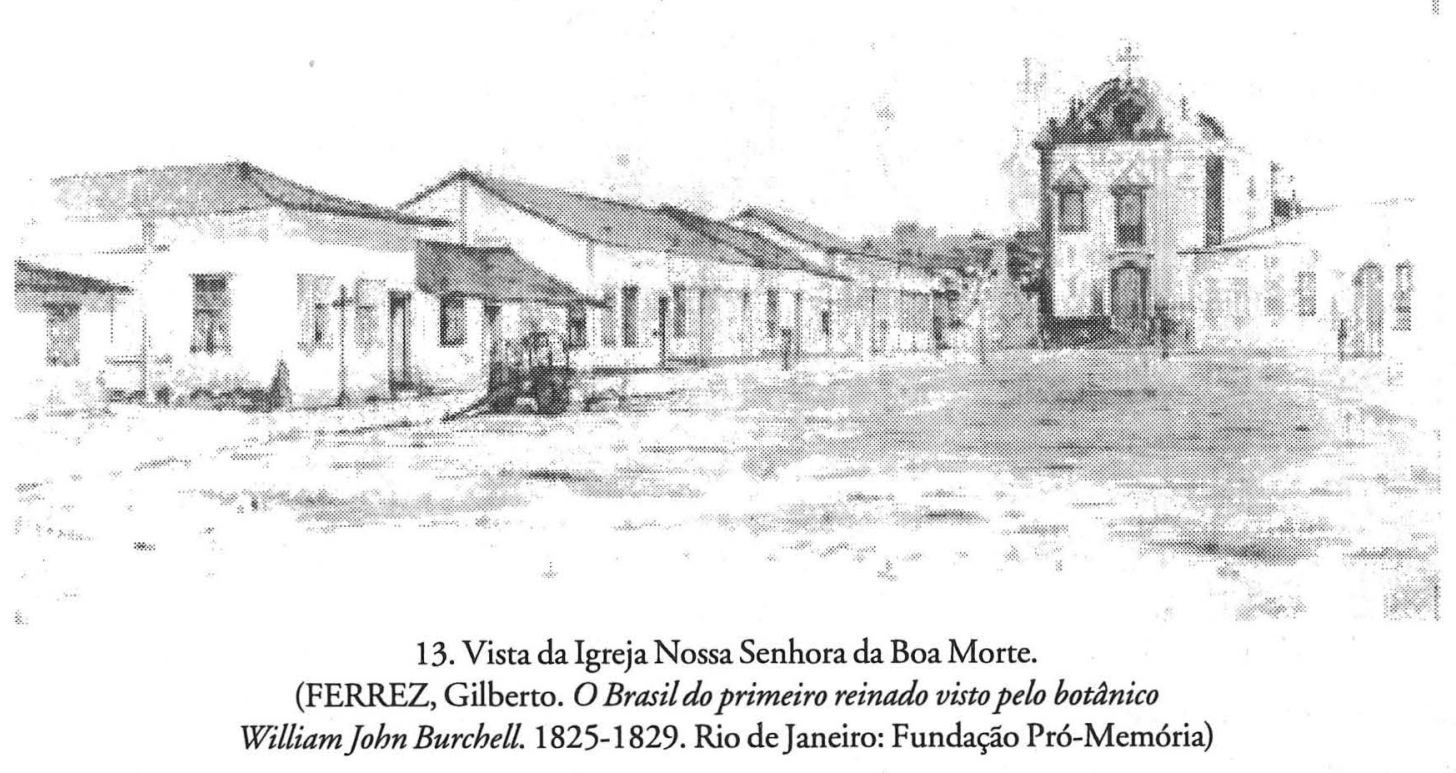

Na paisagem da atual cidade de Goiás, a Igreja Nossa Senhora do Carmo está visivelmente prejudicada, porque se situa em meio de quadra e não dispóe de grandes recursos formais, ou de uma escala generosa que the proporcione uma volumetria solta, ou um melhor destaque no contexto urbano. Sua construção, executada a partir dos tradicionais princípios adotados no Arraial de Santana, foi iniciada por volta de meados do século XVIII e alterada pelas propostas de realinhamento de 1782 . A capela, inserida no novo traçado da Vila, permitiu que novos edifícios fossem erguidos ao seu redor, adquirindo a atual configuração.

Nossa Senhora da Abadia, entre todas as igrejas existentes, foi a única edificada a partir do traçado proposto por Cunha Menezes, quando Vila Boa já se apresentava com um traçado mais regular, formado a partir de quadras. No entanto, sua concepçáo manteve o princípio dos edifícios erguidos em cotas mais altas para valorização volumétrica, reforçado pela escolha de uma área formada em esquina pelas ruas Nova e Padre Salvador.

Assim, não obstante as aparentes semelhanças de implantação que as igrejas vilaboenses guardam entre si, ao longo do século elas se organizaram a partir de diferentes articulaçóes com o seu entorno. Num primeiro momento, mais do que uma referência para a populaçáo, o edifício religioso

$\hbar$ foi o elemento propulsor da formação urbana, orientando a abertura de largos e ruas e hierarquizando 
o espaço em função de suas diferentes localidades, relacionadas às irmandades e confrarias do Santíssimo Sacramento, dos Pretos, Pardos e outras que se vincularam às respectivas igrejas. Com a definição da grande praça no ato de fundaçáo da Vila, as igrejas passaram a se relacionar com o espaço urbano de forma distinta. Por certo permaneceram com papel singular na organização hierárquica do espaço urbano, mas não se orientaram exclusivamente por um foco religioso, vale dizer, o Largo da Matriz. $\mathrm{O}$ centro ficou na tensăo entre o sagrado e o profano, entre a igreja e a casa de câmara e cadeia A vila instituiu, portanto, uma nova ordem simbólica do espaço, na qual a "disputa" pelas melhores localidades teve em vista a própria cidade, não mais os anteriores diálogos visuais entre as igrejas e a matriz. Por fim, as várias transformaçóes no tecido da cidade decorrentes dos novos valores da cultura iluminista impuseram critérios de orientação e ordenação dos edifícios a partir de traçados mais rigorosamente regulares, que não visavam a outro significado senão ao da "ordem da razão". Nessas diferentes experiências e práticas urbanísticas da Expansão Ultramarina, a arquitetura religiosa foi sempre um elemento crucial da formaçáo de cidades.

\section{2 \\ C A P I T U L O}

O EDIFÍCIO

DA ORDEM SOCIAL 

formais e estilísticos, mas também aos seus planos de necessidades, organizaçóes de espaço e relações urbanas, requer a consideração de condicionantes sociais e institucionais, de normas civis e eclesiásticas, influenciadas pela aliança que se estabeleceu entre o Estado português e a Igreja. Para se considerar tais condicionantes e suas inter-relaçóes com a arquitetura, deve-se partir, primeiramente, dos vínculos que a igreja manteve com a coroa, das suas instâncias de jurisdição e das dimensóes sociais que toda essa estrutura possibilitou.

Em Vila Boa de Goiás, as legislaçóes eclesiásticas, estatais e as relaçóes sociais incidiram na construção das igrejas e capelas, apesar da inexistência de ordens religiosas. Revelaram-se através de associações leigas, que substituíram responsabilidades que, em princípio, eram estatais.

No tecido urbano, essas legislaçóes e as iniciativas dos grupos leigos, juntamente com as ações de particulares para a construção das igrejas promoveram uma ordenação espacial hierarquicamente marcada por edifícios religiosos, avaliados pelo seu grau de importância, pelas suas dimensóes, imponência e implantaçóes em diferentes sítios, manifestando e, por assim dizer, regulando a estrutura social de Vila Boa.

\subsection{A ADMINISTRAÇÃO ECLESIÁSTICA EM GOIÁS}

O século XVIII, para os países Ibéricos, caracterizou-se por complexas e imbricadas relaçóes entre a Igreja e o Estado, unidos intimamente através do regime de Padroados, ${ }^{1}$ que concedia amplos

1 "No decorrer do tempo, o Padroado transformou-se numa tutela do direito magéstico em assuntos espirituais e eclesiásticos. Além da concessão de posse de terras descobertas, a coroa portuguesa adquiriu também o direito de recebimento de dízimos, apresentar bispos e demais eclesiásticos, fundar conventos e seminários, criar paróquias, fixar número de religiosos que podiam vir para a colônia, controlar a comunicação entre as autoridades eclesiásticas e o Papa e vice-versa, dar ou recusar autorização de publicar, em suas terras, os documentos pontifícios. Em troca, tinha como obrigaçáo zelar pela construção e conservação dos templos, prover as igrejas e capelas de tudo o que necessário fosse para o culto; remunerar o clero e missionários e promover a expansão da fé católica." VALE. Marília M. Brasileiro. Arquitetura religiosa do século XIX no antigo sertão da Farinba Podre. Tese 
privilégios aos monarcas e lhes permitia estabelecer diretrizes para a estruturaçáo da colônia, conforme suas conveniências e desejos, tornando-se patronos de seu país e das terras conquistadas. A união dessas instituiçōes representou uma relação de direitos e obrigaçōes: ao Estado, competiram as funçóes administrativas das capitanias, como as de fiscalizar impostos, erguer edifícios religiosos e públicos; e à igreja, a evangelização e divulgação dos dogmas cristãos. Para uma melhor implementaçáo dessa administração político-religiosa, o governo português instituiu órgáos específicos, denominados: Casa de Suplicação, Conselho Ultramarino, Mesa de Consciência e Ordem, e instituiçóes ordinárias do poder colonial, que respondiam pelas questóes jurídicas e eclesiásticas. Ao Departamento de Consciência e Ordem caberia, além de outras ações, conceder licenças para a construção de Igrejas, apenas liberadas após verificação dos recursos disponíveis das ordens, confrarias e paróquias, exigindo patrimônio necessário para os novos empreendimentos. Ao Conselho Ultramarino couberam os pareceres sobre as questôes coloniais, passando, preliminarmente, por avaliaçôes de procuradores e desembargadores da coroa.

Na capitania de Goiás, a Igreja chegou em 1726, com eclesiásticos que, além de divulgarem a fé, contribuíram para a implementação da política colonial portuguesa. Até 1749, a capitania pertenceu a São Paulo. Depois dessa data adquiriu independência política, mas a sua administraçáo religiosa permaneceu sob a jurisdiçáo do Bispado do Rio de Janeiro até 1805. O Bispado do Rio de Janeiro havia se formado em 1676, cobrindo uma extensáo que abrangia todo o território do Rio e a costa marítima brasileira do Jequitinhonha até o Rio da Prata. Tamanha extensão territorial dificultava uma efetiva fiscalizaçáo e, em 1745, a diocese ${ }^{2}$ desmembrou-se em cinco territórios formados pelos Bispados do Rio de Janeiro, Dioceses de São Paulo e Minas Gerais e as Prelazias de Goiás e Cuiabá, instituído pela Cúria Romana através da "Bula Candor Lucis Aetene." Entretanto, Goiás, mediante numerosas e prolongadas vacâncias, permaneceu ainda sob a antiga jurisdiçáo do Bispado do Rio de Janeiro.

A criaçáo da Prelazia de Goiás apresentou-se como uma solução conveniente para a metrópole, pois foi reconhecida pela Santa Sé e garantiu e legitimou o domínio das terras goianas pelos lusitanos. Diferentemente de bispados que eram erguidos em cidades e com catedrais, a prelazia contou apenas com a elevação de sua antiga capela a Matriz, regida por um bispo in partibus, que, embora tivesse poderes de jurisdição, não podia administrar os sacramentos de ordem.

$\mathrm{Na}$ arquitetura, com a prelazia, as construções de ermidas, capelas e capelas curadas foram controladas por um conjunto de normas indicadas e registradas a partir dos números 683 até $686 \mathrm{~d}$ Constituiçáo Primeira do Arcebispado da Bahia, um importante documento redigido em 1707 e que compreende 1318 parágrafos, escritos em cinco livros, com diretrizes que regeram a religião por muito tempo, náo só no que diz respeito às orientaçōes da vida religiosa mas também quanto a procedimentos construtivos específicos para reformas de igrejas e escolha de locais para edificá-las, conforme se lê no artigo 687:

2 "Diocese é uma unidade administrativa básica da Igreja, com circunscriçăo territorial autônoma e de direito próprio presidida por um bispo. A prelazia é uma diocese em embriāo, mas independente de uma diocese e sem bispo e freguesia. Seria hoje paroquia com suas capelas filiais possuindo gealmente capelaes permanentes. MORAES, Cristina de Cassia Pereira. "O central.Set. 1999.
(...) as Igrejas devem-se fundar, e edificar em lugares decentes, e acommodados, pelo que mandamos, que havendo-se de edificar de novo alguma igreja parochial em nosso Arcebispado, se edifique em títio alto, e lugar decente, livre de humidade, e desviando, quando possível, de lugares immundos, e sordidos. ${ }^{3}$

O padroado organizava-se ${ }_{2}$ grosso modo, por uma estrutura administrativa que configurava distribuiçóes setoriais ao encargo de autoridades civis e religiosas, compreendendo arcebispados, bispados, prelazias, dioceses e paróquias. ${ }^{4}$ Essas últimas foram delimitaçóes territoriais eclesiásticas de referência do povo, associadas a uma igreja, como uma espécie de distrito. Com tal estrutura, era de se esperar a paróquias, nas quais se que a criaçáo de capelas fosse importruturas sociais e administrativas sólidas para a consolidaçáo efetiva de uma populaçáo.

Após o Concílio de Trento, as paróquias apresentaram-se como unidades de destaque e excelência na missáo clerical, responsáveis pelo discurso centralizador das práticas religiosas. No panoram lecial do século XVIII, coube a elas o exercício de um importante papel de caráter legislador, como a

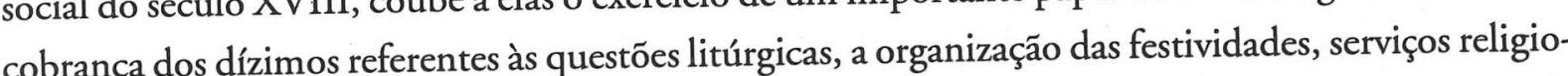
cobrança dos dízimos referentes às questôes litúrgicas, a organizaçá das festividades, serviços religiosos, ereção de capelas particulares, etc. Entretanto, "nos individualizada. Quando se poderia estabelecer, o Estado a impediu, através de toda uma legislação restritiva. Assim não restou à Igreja outro recurso senão o de atrelar-se às associaçóes leigas". ${ }^{5}$ Ficou, portanto, absorvida pelas questóes burocráticas, perdendo sua ação na esfera de outras representaçóes religiosas e abrindo precedentes aos leigos, que assumiram a prática de várias funçóes urbanas, inclusive da construçáo de igrejas e capelas, que se constituíram em verdadeiros símbolos de estabilidade e segurança comunitária.

Através das paróquias, das irmandades e confrarias formou-se uma sociedade na qual ninguém escapava à necessidade de apelar para instituiçōes religiosas para conseguir emprego, emprestar dinheiro, garantir sepultura, providenciar dote para a filha que queria casar-se, comprar casa, arranjar remédio". 6

Náo obstante a importância da paróquia, foram as irmandades os verdadeiros grupos dinamizadores de açóes nos núcleos urbanos de caráter aluvionário e tornaram-se peças importantes na estrutura social da colônia. Em sua grande maioria, instituíram-se antes mesmo de possuírem seus espaços religiosos, formando-se não apenas para a constituição de laços fraternos e espirituais, mas Lén também para cobrir neces

3 Arquivo da Biblioteca Mário de Andrade. Constituiçóes Primeiras do Arcebispado da Babia. Săo Paulo.

Em sentido estrito, a paróquia era uma entidade diocesana limitada, cuja populaçăo possuía área determinada e ministros que s, numa significaçăo prática, embora menos freqü̉ tremente fosse definida, a Paróqui assumia o sentido de um território.

BOSCHI, Caio César. Os leigos e o poder. São Paulo: Ática, 1986. p. 23.

in 6 HOORNAERT, Eduardo. Formaçäo do catolicismo brasileiro, 1550-1800. 3 ed. Petrópolis: Vozes, 1991. p. 18 


\subsection{OS CONDICIONANTES SOCIAIS E INSTITUCIONAIS}

O estudo das capelas é central para a compreensáo dos núcleos urbanos mineratórios, porque foram elas que assumiram um papel decisivo nas estruturaçóes espaciais e sociais, efetivadas de forma hierárquica e excludente. Foram elas a grande referência de uma populaçáo que, segundo Boschi, fo carente de atividades mais dinâmicas e utilizava-as por serem locais comunitários e de reais significados religiosos. Abrigavam diversas funçóes, como as intercomunicaçóes expressas em festas, casamentos, funerais e batizados. Ao se erguerem igrejas e capelas não se pensava apenas nos aspectos espirituais da população, mas os intuitos de agregação e interação também estavam implícitos, formando associaçóes que se fortaleceram ao longo do tempo por atuarem em várias dimensóes com propósitos religiosos, beneficentes e de ajuda mútua.

$\mathrm{Na}$ Capitania de Goiás, as capelas foram erguendo-se paralelamente à formação dos aglomerados urbanos decorrentes de descobrimentos auríferos e, portanto, diretamente relacionados aos crescimentos econômico e populacional. Ferreiro, Ouro Fino e Barra foram os primeiros arraiais dos "Guayazes", surgidos com suas capelas, o último sendo o primeiro a levantar uma dedicada a Nossa Senhora do Rosário. Com a formaçáo de novos povoados, outras capelas foram construídas e dedicada diversos santos de devoção: Nossa Senhora da Conceição, Nossa Senhora do Rosário, Nossa Senhora da Penha, São João Batista, Nossa Senhora do Pilar, Santana, etc. Em 1727, às margens do Rio Vermelho, constituiu-se, conforme visto, a Capela de Santana, com o arraial de mesmo nome. Posteriormente, com a criação de sua paróquia em 1729, transformou-se na primeira Freguesia e depois em Vila Boa de Goiás.

À medida em que a população goiana fixava-se e organizava-se em associaçóes leigas, aumentava conseqüentemente a demanda de solicitaçóes para a criação de espaços religiosos que comportassem atividades necessárias à sua sobrevivência. Em 1783, Luís da Cunha Menezes apresentou à Coro 21 freguesias e 16 capelanias. Após essa data, a capitania passou a contar com um total de 27 freguesias, com suas respectivas matrizes, e 44 capelas filiais. ${ }^{8}$

Entretanto, era interesse da comunidade que o reconhecimento de suas capelas se fizesse ficialmente, como afirma Murillo Marx ao descrever o processo de reconhecimento institucional de capelas e arraiais como um desejo social:

(...) uma ermida, uma capela eram, e foram por tanto tempo, uma aspiração de um pequeno arraial. A assistência desejada, a confraternizaçăo acostumada e os aspectos institucionais eram justificado por tal aspiraçăo. Não bastava, contudo, erguer uma ermida; não bastava construir, por melhor que fosse, uma capelinha; era necessário oficializá-las. Não era suficiente dotar o povoado de um abrigo para o exercício religioso em comum; era necessário sagrá-lo. ${ }^{9}$

7 BOSCHI, Caio César. Op. Cit. p. 22.

Após essa data, a capitania contava com um total de 27 freguesias, com suas respectivas matrizes, e 44 capelas filiais. MORAES, Cristina de Cássia Pereira. Op. cit., 1999 .

MARX, Murillo. Cidade no Brasil terra de quem? São Paulo: Nobel Editora/ Universidade de Săo Paulo, 1991. p. 19.
Dois eram os procedimentos de reconhecimento dessas capelas: as coladas, ${ }^{10}$ que garantiam a presença de um padre sustentado pelo Estado português e recursos para a manutenção de suas igrejas; e as encomendadas ou de natureza eclesiástica, erguidas por ordem dos bispos, que solucionavam, temporariamente, gastos da coroa, e atendiam às imediatas solicitaçôes comunitárias, através de acordos com os núcleos populacionais, que deveriam assumir as despesas adicionais através de tributos conhecidos como "conhecenças", "pés-de-altar" e "esmolas da bacia". ${ }^{11}$ Obviamente, segundo a política de colonização portuguesa, as capelas encomendadas multiplicavam-se invariavelmente mais que as coladas, apesar dos inúmeros pedidos para colaçôes, que eram a condição para se contar com maiores facilidades na obtenção de recursos para a construçáo de matrizes e determinaçáo de côngruas ${ }^{12}$ para seus párocos. Em Vila Boa, a antiga capela de Santana, fundada por Bartolomeu Bueno, elevou-se a Matriz no ano de 1743, com colação em 1758, ficando as de Nossa Senhora do Rosário, São Francisco de Paula, Nossa Senhora do Carmo, Nossa Senhora da Boa Morte, Nossa Senhora da Abadia, Santa Bárbara e Nossa Senhora da Lapa como suas filiais.

Entendendo as igrejas e capelas como edifícios de grande importância social, era de se esperar que o desejo dos vários segmentos sociais, agrupados ou não em irmandades, fosse o de possuir o seu próprio espaço religioso, para abrigar suas devoçōes, fazer reuniōes de irmãos, promover festas, garantir sepulturas, além de obter o respeito e o devido reconhecimento social, o que corresponderia a uma definição de status. Entretanto, a realizaçáo desse anseio dependia dos recursos financeiros dos erectores, definindo-se o patrimônio com vários encargos tributários, tais como: taxas para liberaçáo de documentos e licenças oficiais para provisão de equipamentos indispensáveis ao exercício do culto, compras ou cessóes de terrenos, riscos, contrato de execuçáo e, finalmente, a colocação da obra em praça pública para concorrência no regime de "arremataçóes". Esses eram alguns dos fatores que, evidentemente, dificultavam a concretização desses empreendimentos, implicando em constantes esforços dos adquirentes para a obtenção das concessóes de licenças, recursos para a aquisiçáo de patrimônio e cumprimento das normas eclesiásticas, que exigiam locais especiais para as implantaçóes dos edifícios.

Os Patrimônios religiosos eram administrados por uma entidade que devia merecer a autorizaçáo da Igreja e obedecer também aos preceitos das Ordenaçōes do Reino, controlados pelas autoridades judiciárias. A terra, alguma outra dotaçăo em bens móveis, víveres ou dinheiro representavam o dote inicial. Propiciavam, assim, as condiçôes para a construção do templo, para sua manutenção e reparo. Em troca, os fundadores do patrimônio, os que tornavam possível a existência da capela, obtinham atençốes especiais para si e para os seus em termos espirituais, como missa após a morte..$^{13}$

${ }^{10}$ As capelas coladas eram criadas pelos monarcas, fundamentados no direito real do Padroado, conforme se vê no documento a seguir: "Parece a Meza que sendo certo S. Magestade pode prover as Igrejas dos seus Dominios Ultramarinos sem preencher o vigilante cuidado que tanto resplandese no Real Animo de V. Magestade e que sempre cuida vigilantemente em dar as velhas que the săo sugeitas (...). Requerimento do Padre Jozeph Bento de Oliveira para colaçăo. Comarca de Goiás do Bispado do Rio de Janeiro, 27 de outubro de 1767". Arquivo Histórico Ultramarino. Requerimento de 1767, códices 943 a 947. Lisboa. 1 Consistriam as "conhecenças" numa espécie de "dízimos pessoais" cobrados pela obrigaçăo da confissăo anual e comunhâa pascal eos "pé-de-altar" em ofertas voluntárias por sacramentos administrados. HOORNAERT, Eduardo. Historia da igreja do
Brasil. 4. ed. ed Petrópolis: Vozes, 1992. p. 284-286.

Esmola da bacia - "Recolhida durante o sacrifício da missa, por ocasiảo de festas". MORAES, Cristina de Cássia Pereira. $O$

12 "Côngruas era o sustento financeiro pago pelo padroado através da folha eclesiástica". Idem.

13 MARX, Murillo. Op. cit., p. 39 
Quanto à legislação mais específica sobre o direito de construir, Francisco de Paula Dias de Andrade, em Subsidios para o estudo da influência da legislação na ordenaçãa e na arquitetura das cidades brasileiras, entende que o mais completo tratado sobre as questóes relativas às edificaçóes civis, religiosas e a urbanística é o de Manoel Alvares Ferreira (1706) ou Emmanuel Álvares Ferreyra, distribuído em seis volumes: o primeiro trata das classificaçōes das igrejas, normas legais e eclesiásticas para suas construções, soerguimento de colégios, igrejas patriarcais e paroquiais, capelas, oratórios públicos e particulares e dos padroados, etc; o segundo estabelece condiçóes de uso para esses edifícios, locais sagrados, públicos e particulares; o terceiro discorre sobre os aspectos relacionados à reconstruçáo, demolição e recuperação de edifícios; no quarto livro estão os trâmites para concessão de licenças, interdição e embargos; e nos livros quinto e sexto, processos judiciais referentes às construçóes e licenças legais para demoliçóes.

Documentos de 1775 atestam que normas relativas a licenças e demarcação de igrejas previstas pela Constituiçáo do Arcebispado da Bahia ${ }^{14}$ e pelo código de Manuel Alvares alcançaram Vila Boa, incidindo na construçáo de seus edifícios religiosos, sendo possível observar que, mesmo sem a citação do "risco", houve claras especificações de "esquemas" definidos no ato da demarcação, como posiçáo da obra no terreno, local destinado ao adro e definição de medidas.

Aos 3 dias do mez de setembro de 1775, nesta Villa Boa de Goyaz, em morro de Santa Barbara, em a entrada que vai para o Carreiro, Barra e Anta e onde eu, escrivão adiante nomeado, fui vindo sendo achi com o muito Revdo Ministro Dr. Francisco das Chagas Vidal de Mendonça Ávila Corte Real, Vigário da Vara nesta Villa e sua Comarca, para o efeito de assingnar o lugar em que se há de erigir a capela da gloriosa Santa Bárbara, a requerimento dos devotos da mesma Santa, em presença do mais povo que servirāo de testemunhas e vão assignadas abaixo, a que tudo se procedeu a medição e demarcação no respectivo lugar e plano em que se há de fundar a dita capela com seu adro o qual consta de 15 braças de comprimento 10 de largo; para que se puseram os marcos e se assentou uma cruz no lugar onde havia de ficar o altar da mesma Santa, e para constar fiz este termo que assignarão o Revmo. Dr. Vigário da Vara, e eu, Manoel Teixeira Paiva, escrivão do auditório ecclesiastico (..... ${ }^{15}$

O documento acima possibilita a leitura dos trâmites legais para a aquisição da licença para a construção da capela de Santa Bárbara em Vila Boa. No primeiro momento, os solicitantes dirigiram se à Câmara, requereram as comprovaçóes patrimoniais e a autorização para construir. Após deferimento, encaminharam as comprovaçôes para a fiscalizaçáo, que se realizou na área a ser edificada, sendo o vigário o próprio Juiz da Vara que, juntamente com o escrivão, foram os realizadores das demarcaçóes. Considerando-se o tamanho e a simplicidade da capela de Santa Bárbara, pode-se supor

14 Artigo 687 - "Conforme direito Canônico, as Igrejas devem fundar, edificar em lugar decente (...) desviando quando possivivel, de lugares immundos, sordidos, de casas particulares, de outras ao redor dellas, que se faça em tal proporçăo, que não somente
seja capaz dos fregueses todos, mais ainda de mais gente de fora quando concorrer sas festas se ed seja capaz dos fregueses todos, mais ainda de mais gente de fora, quando concorrer as festas, se edifiquem em lugar povoado,
onde estiver o mayor número dos freguéses. E quando se houver de fazer, será com licença nossa feyta vistoria: Iremos prieyro ou outra pessoa de nosso mandado, levantar huma Cruz no lugar onde houver de estar a Capella mayor, se demarcaráo a ambito da Igreja, adro della. Arquivo da Biblioteca Mário de Andrade. Constituisāo do Arcebispado da Babia. São Paulo.

${ }_{15}$ Arquivo Frei Simāo Dorvi. Auto de demarcaşäo da Igreja Santa Bárbara. Documento avulso de 1775. Cidade de Goís. que esse foi o procedimento burocrático habitual para as demais capelas de Vila Boa, em conformidade com as determinaçóes da Constituiçáo do Arcebispado. Nessa lei suprema, essa era, de ordinário, a determinação sob cujas responsabilidades ficariam as autorizaçóes de construção de capelas, fiscalização do local e verificação das condiçōes apropriadas para a construção, em observância às legislaçóes canônicas e jurídicas. Com as prerrogativas do Padroado, ao "funcionário" cabia conceder licenças para as construçóes, ficando para a igreja somente as visitas de aprovação das condiçóes da obra. No caso apontado, juiz e padre assumiram uma dupla função, permitindo perceber as imbricadas relaçóes entre as instâncias da Igreja e do Estado. ${ }^{16}$

No Tratado de Manuel Álvares, fica evidente a atribuição dessa atividade: "cabia ao magistrado e às autoridades urbanas em geral, a fiscalização das construçóes e da utilização dos espaços da cidade. O licenciamento de novas construçóes dependia do parecer do Conselho", ${ }^{17}$ o que efetiva a notoriedade do poder estatal ao lado das legislaçóes eclesiásticas, numa disputa que veio se desequilibrando a favor do Estado até o final do século.

No que se refere à implantação do edifício, a legislação eclesiástica previa, em um dos artigos das Constituiçóes Primeiras do Arcebispado da Bahia, ${ }^{18}$ que ele deveria ser levantado em locais específicos, conforme suas diferentes categorias: às igrejas paroquiais, aconselhava-se que tivessem capelamor voltada para o oriente, ${ }^{19}$ de maneira que a porta estivesse instalada em direção oeste. Se isso náo fosse possível, que a implantaçáo do edifício se voltasse pelo menos para o meio-dia. Em hipótese alguma poderia estar voltada para o ocidente. Para as capelas, a lei não previa grandes exigências, a não ser as condiçóes básicas para a realizaçáo do culto, devendo elas apresentarem-se de tal modo que "náo o sejam de escândalo pela pouca decência, e ornatos delas"; e especificaçáo de materiais, estabelecendo "pedra e cal e náo somente de madeira ou de barro, assignando-lhe dote competente ao menos de 6.000 réis cada anno para fábrica, reparação e ornamentos". ${ }^{20}$

Marília M. B. Teixeira, em seus estudos, observa que, nas capelas mineiras, geralmente não houve uma correspondência direta das dimensões e planos dos edifícios e suas categorias eclesiásticas,

${ }^{16}$ A intervençăo estatal também pode ser vista com Cunha Menezes, quando ele solicita a construçăo de mais capelas para a Capitania de Goiás, como se lê, neste documento: "Que no anno de mil settecentos e oitenta fora ouvidor por provisão do Conselho Ultramarino na datta de nove de novembro de setecentos setenta e oito, sobre huma súplica que a V. Magestade fizerăo os moradores e cultivadores do vasto certăo daquele Estado do brasil, e América Meridional Portuguesa.

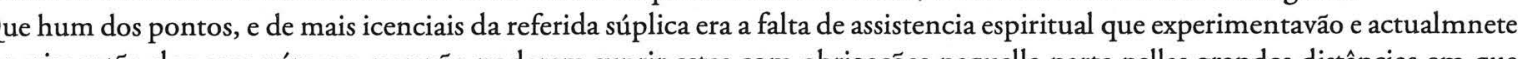
experimentåa dos seus párocos, por năo poderem suprir estes com obrigaçoes naquella parte pellas grandes distâncias em que
ficavam seus fregueses. Que sobre este ponto icencialissimo respondera com oparecer do Ouvidor Geral...mandou-se criar uma capella Parrochial no Arrayal de corgo do Jaragua (...) em consequencia de huma Pastoral do Bispado do Rio de Janeiro(...).Arquivo Frei Simaro Dorvi. Sobre a construy̧äo de capelas na Capitania de Goiás. Documento avulso de 1780. Cidade de Goiás.

7 ANDRADE, Francisco de Paula Dias. Op. cit., p. 79.

18 "688 - Igrejas Parochiaes teráo Capella mayor, e cruzeiro, se procura que a Capella maior se funde de maneyra, que posto o sacerdote no Altar fique com o rosto no Oriente, não podendo ser, fique para meyo dia, mas nunca para o Norte, nem para o Occidente. Terăo pias baptismaes de pedra, e bem vedadas de todas as partes, armários para os Santos Oleos, pias de agoa benta, um púlpito, confissionários, sinos, sala de Sacristia, haverá mo ambito e circunferênncia dellas adros, e cemitérios capazes para nelles se enterrarem os defuntos, ao quaes adros serão demarcados por nosso Provisor, ou Vigário Geral, como acima fica dito, e os autos
Paulo.

19 "Até o Concílio de Trento, cujas directivas são difundidas a partir da segunda metade do século XVI, as igrejas deveriam ter o altar mor orientado para nascente e a porta principal, para poente". CARITA, Rui. "As cidades atlânticas do século XVI:

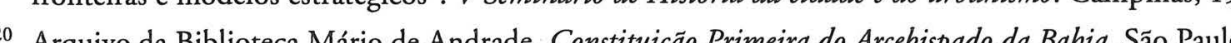


podendo uma pequena capela ter sido elevada a matriz sem que necessariamente tivesse uma mudança de edifício. "O processo mais comum foi, no entanto, o de substituição das pequenas capelas por outras, de maiores dimensões, após ser elevada à matriz, procurando torná-la mais adequada e significativa de seu novo status", ${ }^{21}$ conforme se atesta em Vila Boa, onde se ergueu uma nova igreja tâo logo houve a identificação do potencial econômico do emergente núcleo populacional, representado simbolicamente pela Matriz de Santana.

Por fim, a legislaçáo eclesiástica preocupava-se com equipamentos considerados essenciais à realização do culto, como: pia batismal, armários para Santos Óleos, pia de água benta, púlpitos, confessionários, sacristias, sinos e cemitérios devidamente estabelecidos nos arredores do templo ou nos adros. Ao que parece, essas também foram solicitaçōes legais atendidas pela população setecentista de Vila Boa.

Sobre o náo atendimento a todas as normas a serem cumpridas para o soerguimento de igrejas em Vila Boa, atribui-se muito desse quadro às próprias dificuldades regionais, como as das grandes distâncias dos núcleos populacionais litorâneos e as privilegiadas preocupaçôes do governo com as atividades de fiscalização do ouro. Esses fatores contribuíram para que não houvesse a completa operacionalização das normas para a construçáo de edifícios e a não utilizaçáo dos materiais construtivos especificados, substituídos por outros que se adaptaram às condiçốes locais, a que a taipa se adequou mais eficazmente.

\subsection{OS ESPAÇOS RELIGIOSOS E A CIDADE}

Uma melhor compreensão dos condicionantes do processo de composição dos edifícios religiosos de Vila Boa depende de um olhar atento às condiçóes culturais e sociais de sua população. E, nesse sentido, torna-se imprescindível perceber a participação dos erectores frente às construçôes das igrejas, o que implica em dizer que essa relação também passa pelas lógicas internas de uma sociedade cuja dinâmica se fez a partir de hierarquias e exclusões, configuradas nas estruturas das irmandades. ${ }^{22}$ Estabelecer vínculos dessa natureza possibilita o entendimento das causas que levaram esses edifícios a adquirir distintas importâncias simbólicas no contexto urbano, como estabeleceram-se relaçóes com o seu entorno mais imediato e quais foram os usos dos seus espaços internos.

${ }^{21}$ VALE, Marlia M.Brasileiro Teixeira. Op. cit., p. 66

${ }^{22}$ Tais relaçōes hierárquicas podem ser vistas nas seguintes documentaçōes:

I - [rmandade do Santíssimo Sacramento] - "Nesta Irmandade, nāo haverá número certo de Irmāos e Irmās, e se procuraraá o maior para o mais promto serviço, honra, e louvor do Divinissimo Sacramento, fazendo-se acceitaçăo de Irmāos de Hum outro sexo, assim casados como solteiros, todas as vezes que tiverem doze annos de idade, e dahi para cima".
II - "Todos os Irmäos, e Irmās, que se

II - "Todos os Irmâos, e Irmäs, que se assentarem de hum e outro sexo, serăo todas pessoas brancas idôneas, e sufficientes, e

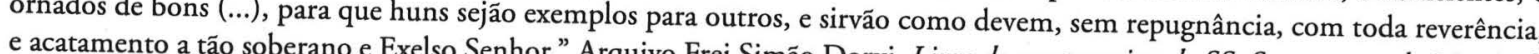
S.ta Anna de Goiaz. Cidade de Goíss. [Irmandade do Rosírio] - "Nesta Irman

mais prompto serviço, (...) e louvor de Nossa Senhora do numero certo de Irmãos e Irmāss, porque na mesma se aceitarăo pelo que nela se quizerem assentar por Irmăos, tanto de sexo, como de outros, assim pretas, e de qualquer condiçăo, e qualidade Simáo Dorvi. Livro de compromisso da Irmandade de Nossa Senhora do Rosário de Villla Boa de Goyaz Docous (...). Arquivo Fre de Goiás.
A sociedade colonial de Vila Boa foi formada por associaçóes leigas, ${ }^{23}$ que se constituíram, inicialmente, por grupos de pessoas devotas de um mesmo santo padroeiro, compartilhando as mesmas necessidades. Essas associaçóes civis foram responsáveis por algo vivo no cotidiano da época, pois, através de suas manifestaçóes sociais, principalmente no âmbito religioso, moldaram importantes traços culturais na regiáo. Criadas, em sua grande maioria, por leigos, assumiram funções suplementares às da igreja, semelhantemente a outras regióes do Brasil. Agiam com poderes de decisóes no âmbito social e religioso. Surgiram e multiplicaram-se paralelamente à criação de capelas e até mesmo antes da formação de muitos arraiais. Caracterizavam-se por estruturas hierárquicas e seletivas na incorporaçáo de seus membros, implicando sérios compromissos que lhes exigiam significativo grau de envolvimento, com ativa participação. Tinham regulamentos em forma de estatuto ou compromisso particular, que estabeleciam os direitos e deveres dos seus membros.

Quanto à construção de Igrejas e capelas, apenas se tem notícia da Irmandade do Santíssimo Sacramento como coordenadora das obras da Matriz de Santana e algumas indicaçóes documentais apontam-na também como a que a levantou a Igreja dos Pretos, juntamente com a Irmandade do Rosário.

No âmbito urbano, as distinçóes sociais ${ }^{24}$ dos erectores contribuíram para nortear a localização da igreja, com implantaçóes que se fizeram a partir de critérios de escolha claramente contrapostos, marcando o caráter hierarquizado dessa população. A Matriz de Santana, que ocupou o mesmo local da antiga capela fundada pelo descobridor de Goiás, foi implantada em terreno mais elevado, distante das minas, em área de expansão da cidade e com população econômica e socialmente expressiva habitando ao seu redor.

${ }^{23}$ De acordo com o parecer do visitador Pe. Alexandre Marques do Vale, no ano de 1734, várias delas já existiam na Igreja de Santana, portanto, antes mesmo de o arraial se elevar a categoria de Vila. Faço saber que aos oito de agosto deste prezente anno de 1734 vezitey pessoalmemte esta igreja da Snra. Santa Anna, em prezenç̧a dos sacerdotes, confrarias, nobreza, e povo della (...) os Capellaens das Irmandades seraō confessores, e sem o serem năo poderăo ser Capellaens e ajudarăo nas confisssóes da "Diarsma, e jubl das a Reve "Dizem o Juiz, officiais e mais Irmaons da Meza da Irmandade do Glorioso S. Miguel Arcanjo, e Almas, erecta na Igreja Matriz Magestade seja servida mandar, que thes passe Provizão de confirmação (....)". Arquivo Histórico Ultramarino. Provisāo de 1781. Lisboa.

Este padre logo que entrou a exercer o Seu emprego, quis tomar contas a algumas Irmandades (...). Irmaons dos Passos, os das Este padre logo que entrou a exercer o Seu emprego, quis tomar contas a algumas Irmandades (...). Armaons dos Passos, os das
Almas e on de Nossa Senhora da Boa Morte (..) Villa Boa de Goyaz, 12 de julho de 1752". Arquivo Frei Simåa Dorvi.
Documentos avulsos de 1752. Cidade de Goiás.

"Attestamos, e Certificamos, que tudo, quanto os Suplicantes referem neste e seu requerimento, he verdade; pois năo havendo, como năo há nesta Villa Irmandade de Mizericó́rdia, esta das Almas supre aquella falta sem emolumento, nem utilidade algua, antes a sua custa exercita em todas as ocazióes precizas todos os actos de Caridade e piedade, náo so com os justiçados $e$ sepultando aos que falecem". Arquivo Histórico Ultramarino. Documento da Camara de Villa Boa, 1781. Pasta de Goiás. Lisboa. Cunha Mattos, em Chorographia Histórica da Provincia de Govaz, lista a presenca de aloumas irmandades instaladas em capelas: Cunha Mattos, em Chorographia Historica da Provincia de Goyaz, lista a presença de algumas irmandades instaladas em capelass
"A Matrriz tem as confrarias do Sacramento, Santana, Santo Antônio dos militares e empregados públicos e a do Senhor dos Passos. A igreja Nossa Senhora da Boa Morte, a confraria de homens pardos e Nossa Senhora do Carmo tem a Irmandade dos Pretos de Santa Efigênia”. MATTOS, Cunha Raymundo José da.Chorograffiia Historica da Provincia de Goyaz. Goiânia: Líder, $[s / d]$. p. 98.

24 "Os brancos, nas minas dos Goyazes, reuniam-se, por exemplo, nas Irmandades do S. Sacramento (as mais antigas), ou do Senhor dos Passos; os pretos, geralmente, nas de N. S. do Rosário e S. Benedito; os pardos, sob a proteçăo de N. S. do Livramento, Santa Efigennia, N. S. do Carmo e N. S. das Merces." MAGALHÄES. Carlos Fernando Filgueiras de. "Confrarias 
A Igreja dos Pretos implantou-se em área distante do núcleo fundacional, com acesso interceptado pelo Rio Vermelho e era circundada por habitaçóes de negros e forros. Nossa Senhora da Boa Morte, iniciada por militares e cedida posteriormente à confraria dos pardos por imposiçáo da coroa, situou-se em local privilegiado, simbolicamente erguida sobre os alicerces da antiga casa de Bartolomeu Bueno da Silva, ladeada pelas melhores casas da Vila e próxima à Matriz.

As demais capelas, ${ }^{25}$ como as de Nossa Senhora da Lapa, levantada por Vicente Vaz Rocho da Irmandade dos Mercadores; Nossa Senhora do Carmo, iniciada por Diogo Luiz Peleja, secretário do governo; São Francisco de Paula, por Antônio Thomaz da Costa, militar vindo de Minas Gerais; Nossa Senhora da Abadia, fundada pelo Reverendo Dr. Salvador dos Santọs Baptista; Senhora da Barrancas, capela pública do cirurgião-mor Antônio da Neiva; Santa Bárbara, erguida por devotos dessa santa e situada mais distante do núcleo populacional; e Nossa Senhora da Abadia, erguida já no final do século, assumiram posiçốes estratégicas que mostram concretamente as disputas por locais $\mathrm{d}$ destaque no traçado da cidade. ${ }^{26}$

Hoornaert, ao discorrer sobre o espaço interior das capelas, diz que, genericamente, todas foram organizadas em torno da imagem de um santo. Entretanto, o seu real entendimento pode ser feito pela leitura das distribuiçóes dos "lugares", da posição das pessoas, de como se aproximavam dos santos e dos percursos dentro da igreja, "instalando-se uma dialética: a maneira como a sociedade brasileira entendeu a relação entre o homem e o santo não é absolutamente pacífica, mas sim conflitual, manifestando as desigualdades. ${ }^{27}$

Nessa perspectiva, o historiador elabora um esquema básico de distribuição espacial de uma capela setecentista, composta por dois recintos laterais, "à moda de tribuna", destinados aos homens "bons" ou livres, que permaneciam de pé durante o culto, significando o seu destaque social perante o clero, mulheres e escravos; e os arredores da porta, onde ficavam peóes e negros em geral; na parte central, as mulheres, agachadas ou ajoelhadas. A tal configuração de lugares, em que nenhum grupo ultrapassava seus limites, correspondia um alto grau de seletividade, que se mantinha até mesmo na hora da morte, tanto na legislação quanto na escolha dos espaços, com as sepulturas rigorosamente pré-estabelecidas.

A sepultura era um direito sagrado do homem. Mesmo o menos dotado de bens ou de direitos, fazia jus a uma digna sepultura, desde que católico. Apenas o condenado, o infiel, o criminoso, principalmente o que sofresse execução, não tinha o direito a ela, podendo seus corpos serem desmembrados, apodrecerem insepultos ou serem queimados e suas cinzas espalhadas. Mesmo os escravos, com suas associaçōes religiosas, visavam, entre outras finalidades, assegurar a seus membros e irmãos o sepultamento digno e cristấo. ${ }^{28}$

\footnotetext{
${ }^{25}$ Nossa Senhora da Lapa, Nossa Senhora das Barrancas e antiga Nossa Senhora do Rosário ruíram no século passado. A última, no século XX.

26 Outras i Outras irmandades que se formaram em Vila boa de Goiás, como a dos Irmăos dos Passos, as das Almas, Santo Antônio dos
militares e empregados públicos e Santo Sepulcro HOORNAERT Ed Eacentum ainda mais esse caráter segregacionis

28 ANDRADE Fra de Dode Pe. 293.
}

brasileiras. Tese de Doutorado. Săo Paulo: Escola Politécrnica de Săo Paulo, 1966. p. 78.
Ao que parece, os espaços das capelas vilaboenses tiveram ordenaçóes e funçóes similares às apontadas por Hoonaert, em especial quando se confrontam tais conclusões com o termo de compromisso da Igreja do Rosário, cujas indicaçóes de sepulturas foram previstas.

Capítulo 16: Sepultura e sufrágios dos Irmãos - Falecendo: as sepulturas do livro de Compromisso da Irmandade Nossa Senhora do Rosário dos Pretos. (...) juiz, juiza, Rei e Rainha na capela maior para dentro do Arco com 12 missas a cada hum da esmola costumada. Escrivão, Thezoureiro e Provedor: das grades do cruzeiro até o Arco com 8 missas. Os irmãos e irmãs de meza de corpo de Igreja com 6 missas. Irmãos rasos nos corredores e 4 missas. Capellăo no tempo em que estiver servindo no melhor lugar da capella com 12 missas.

Capítulo 17: Sepultura dos que náo săo irmáos - Falecendo alguma mulher, casada com Irmăos desta Irmandade ou filhos de seu matrimônio ou sendo viúva delle sem ter passado a outras núpcias e os filhos ou filhas até a idade de doze annos, se lhe dará sepultura com acompanhamento da Irmandade que levará suas insignes. Os indigentes sepultados por esmola, no corpo da Igreja ou nos corredores.

Capítulo 18: Esmolas por sepultura e acompanhamento, capela maior esmola 16 oitavas, cruzeiro 8 oitavas, corpo da igreja 4 , nos corredores 2 , querendo acompanhamento, dará mais 4 oitavas para qualquer das partes, assim como pagará os que convidarem a Irmandade para outra parte. ${ }^{29}$

O desejo de todas as irmandades de possuir seus próprios espaços religiosos levava os irmáos a freqüentes esforços na aquisição de recursos para o patrimônio necessário à ereção de capelas. Porém, nem sempre permaneciam com os edifícios por um longo período ${ }^{30}$ geralmente pelas grandes dificuldades econômicas e legais que implicava um empreendimento dessa natureza. Em Vila Boa, as iniciativas para se levantarem matriz e capelas não foram apenas provenientes das irmandades, mas também de vários particulares que, assim, não só garantiram seus espaços para a vida após a morte, como alcançaram um considerável "status" entre os vivos. Para Palacin, esse procedimento, bastante estimulado, se justificava pelo fato de os erectores não quererem ceder seu patrimônio nas mãos do Juízo de Órfăos e Ausentes:

(...) seus bens mal vendidos anonimamente, iriam engrossar a burocracia da justiça, e o resto enviado a parentes longínquos, já esquecidos de distantes.Desta forma, preferiam empregar seus patrimônios em vida na construçáo de uma igreja que perpetuaria seus nomes.

Em Minas Gerais, pelas freqüentes dificuldades financeiras das irmandades, vários foram os pedidos de ajuda à coroa para a construção de igrejas, mas poucos foram atendidos. Quando atendi${ }^{29}$ Arquivo so "Na Matriz de Vila Boa (1743), temos a Irmandade do Santíssimo Sacramento desde 1736 e a devoçăo em altares laterais, como São Miguel e Almas, com a Irmandade das Almas desde 1732; a devoçăo dos Bons Passos desde 1745 e, posteriormente, Goiás; na de Nossa Senhora do Rosário, a devoçăo principal a Nossa Senhora do Rosário dos Homens Pretos com sua Irmandade, que em 1804 estará na Igreja de Nossa Senhora do Carmo. Na capela De São Francisco de Paula (1761), temos a Irmandade do Senhor dos Passos que sai da Matriz em 1782 e aloja-se nessa capela encontrando-se até hoje no local.". (sic)

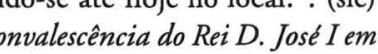

6. 31 BORGES, Ana Maria PALACIN, Lứs. Patrimônio historico de Goiás.Brasilia, SPAHAN/ pró Memória, 1987. p. 14 
dos, eram insuficientes para cobrir as despesas. Dessa forma, as irmandades buscavam recursos em doaçóes, promessas ou esmolas, sustentadas pelo esforço comum, o que deve ter sido um procedimento habitual também em Goiás. Myriam de Oliveira afirma que as exceçôes ficavam para as igrejąs dos negros, evidenciando o interesse da coroa de controlar espacialmente as diferenças sociais, e para as Matrizes, ligadas à administraçáo oficial, o que lhes dava o direito a subvençóes, pela aliança IgrejaEstado. ${ }^{32}$ No Livro 4 da Constituição do Arcebispado, consta a seguinte indicação sobre questões referentes a doaçōes para as Matrizes:

(...) não tratamos aqui do dote que he preciso tenha cada huma das Igrejas Paroquiais porque como todas as deste Arcebispado pertencem à Ordem, e Cavallaria de Nosso Senhor Jesus Crhisto, de que S. Magestade he perpétuo administrador, tem o mesmo Senhor com muion Jesus Crhisto, de que mandado pagar pontualmente, e vão na folha os dotes das Igrejas, que he ceis mil ica providencia e oito para as que estão em Villas: assim como com muto libelo Rei mandar grossas esmo Rei mandar grossas esmolas, assim para a edificação, como para a reedificação das ditas Igrejas. . $^{33}$

Os pedidos de auxílio para matrizes geralmente eram feitos com a conjugação de esforços de duas irmandades - a do Santíssimo Sacramento e a do Santo Padroeiro local -, responsáveis também pela regulamentação documental e construção da obra. Tal sucedeu para a construção da Matriz de Santana de Vila Boa de Goiás que, além do significativo empenho da Irmandade do Santíssimo, obteve pleno apoio do ouvidor, que buscou adquirir um projeto e ajuda para a construção do altar-mor

Este povo, Senhor, se não acha diminuto de zello, se divizão pouco pois antes para o concurso de continuar-se a obra a perfeiçáa; pello que por nós, e pello meso e a incomparável piedade de $\mathrm{V}$. Mag. de a mercê de huma esca grandeza, Capella Mor; pella qual serão memorável a ste pe de huma esmolla, para se aperfeiçoar, e ornar a Santa Anna, protetora sestão memorável a este povo eternamente, a mercê de tấo pio benefício, e a

Julita Scarano sustenta a afirmação de Myriam de Oliveira quanto aos recursos disponibilizados pela Coroa Portuguesa para as construções das igrejas de negros. Acrescenta ainda que atender aos pedidos dos segmentos sociais mais carentes era uma forma de manter a ordem e o (des) equilíbrio social. As irmandades de pretos, na maioria dos casos, eram as primeiras a adquirir suas igrejas.

Em Vila Boa, o procedimento para a construçáo da Igreja do Rosário dos Pretos foi o mesmo, o que se afere por indicaçóes em alguns documentos, tais como a de que dou Pretos foi o mesbastante influente na Vila, "Antoni. Peir Guadalupe,"35 era provisáo do Sr. D. Fr. Antonio de Guadalupe, ${ }^{35}$ era também provedor da Irmandade do Santíssimo Sacramento. ${ }^{36}$ Cabe ainda enfatizar

32 OLIVEIRA, Myriam Andrade Ribeiro de. O rococó religioso em Minas Gerais e seus antecedentes europeus. Tese de Doutorado.
Paris: Université Catholique de Louvain, 1990 . p. 154 .

${ }_{33}$ Arquivo da Biblioteca Mário de Andrade. Cons. p. 154

${ }_{34}$ Arquivo Frei Simāo Dorvi. Ata da Camara de Vílí Bộes Primeiras do Arcebispado da Babia. Livro 4, tit. 686. São Paulo.

35 TELES, José Mendon Dorvi. Ata da Camara de Vila Boa de Goiás de 1746. Documento avulso. Cidade de Goiás

36 "(...) mandarāo os ditos Juiz presidente e os officiais Coleçâo documentos. Goiânia: Editora UFG, 1998. p. 111

Antônio Pereira Bahia que serve em lugar de provedor da Irmandade Alo Santésissta Villa Antonio Rodrigues Braga, chamar Camara 26 de mayo de 1742". Arquivo Frei Simão Dorvi. Ata da Camara de Vila Boa de 1742. Documento avulso. Cidade de
Goíss. que a data de sua construção antecede à da Matriz, que se iniciou em 1743. Esses dados provam que, antes da Matriz de Santana, já havia esforços para se estabelecerem espaços distintos para as duas importantes irmandades, marcando os primeiros traços de segregação na capital de Goiás.

As demais capelas foram erguidas com recursos próprios de seus erectores, sendo permitidas só as devidas solicitações de autorização para pedir esmolas. Iniciadas com grandes dificuldades financeiras pelas ações de particulares, era natural que algumas delas fossem cedidas às irmandades, como se pode ver: Nossa Senhora da Lapa, levantada por Vicente Vaz Rocho, da Irmandade dos Mercadores, e Nossa Senhora do Carmo, iniciada por Diogo Luiz Peleja, secretário do governo, que cedeu a capela ainda incompleta à Confraria de São Benedito dos Crioulos. Quanto às capelas de São Francisco de Paula, cujo erector foi o militar Antônio Thomaz da Costa e Santa Bárbara, erguida pelos devotos dessa santa; e Nossa Senhora da Abadia, levantada pelo Reverendo Dr. Salvador dos Santos Baptista com recursos do povo; e Senhora das Barrancas, capela pública do cirurgião-mor Antônio da Neiva, não há informaçōes de que foram repassadas, nessa época, para alguma irmandade.

Apesar de a prerrogativa do padroado assegurar o direito de criar bispados, paróquias e liberar licenças para a construçáo de edifícios religiosos, fossem matrizes, capelas e ermidas, a Coroa Portuguesa raramente assumiu essa iniciativa, repassando os gastos para a população que, com raras exceçóes, se encarregou das construçóes e manutenção das capelas e de boa parte da matriz de Vila Boa. Entretanto, apesar dos difíceis e parcos recursos, não se pode dizer que a arquitetura desses edifícios foi feita sem exigências estabelecidas por normas civis, eclesiásticas e ativa participaçáo leiga, o que confirma a inserção de Vila Boa no mesmo quadro das demais cidades coloniais do ciclo do ouro, compartilhando, coerentemente, com as estratégias políticas de Portugal.

As expressas proibições para o soerguimento de edifícios religiosos, fossem eles de qualquer natureza, através de licenças emitidas pela Câmara e aval da Mesa de Consciência e Ordens e Sagraçóes, foram práticas que garantiram o pleno exercício do Controle da coroa sobre Vila Boa de Goiás. Contudo, quanto mais repressiva e opressora a açáo fiscalista do Estado, mais acentuadamente se manifestou o espírito associativo de sua população, cuja marca participativa se firmou como um importante condicionante cultural no processo de composiçáo de sua arquitetura, caracterizando uma paisagem urbana pontuada por considerável número de igrejas, que se transformaram em elementos essenciais e referenciais de uma estrutura social de procedimentos disciplinares e hierárquicos.

Tanto na dimensão institucional, quanto na social, as igrejas vilaboenses foram também resultado de condicionantes que influíram em suas concepçóes, configurando uma arquitetura cujas relaçōes espaciais, internas e externas, se articularam a partir de valores político-administrativos e culturais de segregaçáo e hierarquia, típicos do Setecentos colonial, impossibilitando as interpretaçóes arquitetônicas do século passado que partem da visão de isolamento regional para então compreender o processo de algumas cidades coloniais, como Vila Boa. 


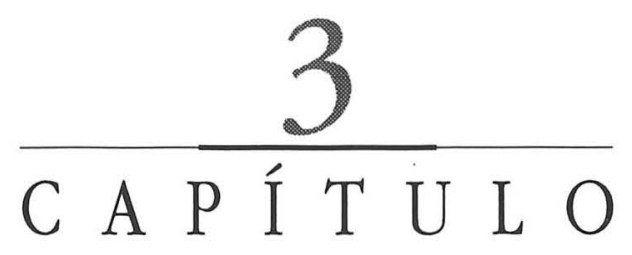

AS CONSTRUÇÕES 


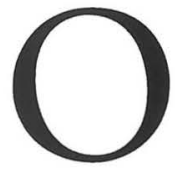
estudo das formas de organização social e de trabalho dos artesãos coloniais traz importantes contribuições para a compreensão da arquitetura do século XVIII. No caso de Vila Boa de Goiás e, no que diz respeito à lógica da construção de seus edifícios religiosos, a negligência dessas relaçóes fez desconsiderar normas, procedimentos de trabalhos e controle de atividades dos artesãos e das obras que influíram na arquitetura das igrejas. Os edifícios foram o resultado de um processo construtivo que envolveu vários grupos de profissionais coordenados por mestres e, conseqüentemente, por diferentes artífices que caracterizaram sua arquitetura com intervenções pontuais nas decisóes, execuçóes e modificaçóes de planos arquitetônicos.

No caso da Matriz de Santana, por exemplo, uma variada gama de profissionais, com diferentes modos de atuação, participou de sua construção e interferiu na formaçáo e natureza do seu espaço. A presença de desenhos previamente elaborados assegurou a unidade da obra e contribuiu invariavelmente para o seu resultado final. A compreensão dessas relaçóes e suas implicações no âmbito das construções religiosas de Vila Boa permitem identificar melhor o caráter dessa arquitetura.

\subsection{OS ARTESÃOS DE VILA BOA .}

A forma de organizaçáo dos artesãos setecentistas remonta à cultura portuguesa dos séculos $\mathrm{XV}$ ao XVIII e ao conhecimento dos processos construtivos dos antigos estaleiros portugueses. $\mathrm{Na}$ antiga capital de Goiás, essa forma de organização e as práticas construtivas dos canteiros de obra chegaram por duas vias com a estrutura colonial: ou através de regulamentos vigentes nas Câmaras, ou por tradição, e recuperaram as contribuições das Capitanias de São Paulo e Minas Gerais, espaços coloniais que mantiveram freqüentes intercâmbios com Goiás.

No mundo português dos séculos XVI ao XIX, o número de artesãos foi bastante significativo e variado, diferentemente do mundo da colônia, cuja quantidade de ofícios e oficiais foi contro$\sim$ lada pela "manutenção de monopólios e das proibições de execução de certas faturas, por parte de 
Portugal, que permitiu, forçosamente, apenas o desempenho das atividades mecânicas essenciais". ${ }^{1}$ Do ponto de vista social, em ambos os casos, os artesãos agrupavam-se em corporaçóes formadas por afinidade, embora as estruturas administrativas dos profissionais mecânicos brasileiros tenham assumido particularidades regionais explicáveis pelas distintas condiçôes de seus quadros históricos e socioculturais.

Segundo Maria Helena Flexor, na metrópole, "os oficiais mecânicos eram agrupados por afinidade de atividades, nem sempre muito lógica, respondendo um ofício como cabeça do grupo e o demais considerados anexos." Esses profissionais, a partir de suas organizaçóes, elegiam juízes e escrivães, responsáveis pela defesa de seus interesses nas Câmaras Municipais.

Para Myriam de Oliveira, ${ }^{3}$ esse tipo de organização teve sua origen na revolução popular que levou ao poder o monarca D. Joáo, o mestre de Avis, que retribuiu o apoio dado pelo "mester" de Lisboa, permitindo a participaçáo dos artesãos no governo municipal. Com essa regulamentação, criou-se em Lisboa a Casa dos Vinte e Quatro, órgão central, composto administrativamente por 24 homens, dois para cada "mester" ou ofício, cujo objetivo principal era o de controlar as excessivas multiplicaçôes de seus líderes. ${ }^{4}$

Na maioria dos núcleos urbanos importantes de Portugal existiram instituiçôes similares, embora sem a mesma significaçáo e abrangência da Casa dos Vinte e Quatro de Lisboa.

Na colônia, a organização dos artesãos se fez por agrupamentos de profissionais especializados em corporaçōes, irmandades comuns ou de ofícios, como as de São José dos Pedreiros e Marceneiros, ${ }^{6}$ Santo Elói dos Latoeiros e São Jorge dos Ferreiros e Serralheiros, ou outra irmandade qualquer. E para o controle desses profissionais, contou-se com as figuras dos "juízes de ofício", que se submetiam aos regulamentos estabelecidos em regimentos espalhados por todas as vilas e cidades brasileiras.

Apesar dessa regulamentação geral, essas associaçóes organizadas em corporaçóes ou irmandades dependiam do desenvolvimento das condiçóes sociais das diferentes capitanias brasileiras. Na verdade, cada vila ou cidade contava com elementos burocráticos específicos, responsáveis por alguns controles, pois "(...) as condiçốes políticas, sociais, econômicas, geográficas, criaram mentalidades, atitudes e situaçōes diversas" 7

FLEXOR, Maria Helena. "Os oficiais mecânicos (artesăos) de Salvador e São Paulo no período colonial." Revista Barroco. n 17 Belo Horizonte: SPHAN/UFOP. p. 139

FLEXOR, Maria Helena. Op. cit., p. 140.

OLIVEIRA, Myriam Andrade Ribeiro de. O rococó religioso em Minas Gerais e seus antecedentes europeus. Tese de doutoramento.

Paris: Universite Catholique de Louvain. 1990. p. 165. 2 v.

FLEXOR, Maria Helena. Op. cit., p. 140.

5 OLIVEIRA, Myriam Andrade Ribeiro de. Op. cit., p. 165

No texto "Confrarias religiosas como expressão artística nos séculos XVIII e XIX nas minas dos Goyazes (irmandades de brancos, pretos e mulatos)" o autor aponta a participaçāo de pedreiros, carpinteiros e telheiros na Irmandade do Santíssimo Sacramento de Meia Ponte, antigo arraial da Capitania de Goiás. MAGALHAES, Carlos Fernando Filgueiras de. Confraria religiosas como expressão artistica nos séculos XVIII e XIX nas minas dos Goyazes. In: Revista do Instituto Historico e Geográftu
$\mathrm{Na}$ Bahia, por exemplo, apesar de algumas distorçóes legais, os artesãos apresentavam-se com estruturas organizacionais similares às de Portugal, agrupando-se segundo suas especializaçóes e com o controle de atividades exercido pelas Câmaras, que contavam com Juízes e Escriváes de ofícios para fiscalização.

Em São Paulo, não chegaram a se agrupar em corporaçóes específicas, o que permitiu constantes irregularidades. Possuíam seus escrivães de ofícios apenas em cumprimento à imposiçáo da Câmara, visando a atender muito mais às Ordenaçóes do Reino que aos próprios interesses dos grupos profissionais. $\mathrm{O}$ mesmo pode-se dizer em relaçáo a Vila Boa, onde também não existiram corporaçóes ou associações de ofícios. Nela, os artesãos associavam-se em diferentes irmandades locais, formando um conjunto de profissionais composto por pessoas de várias camadas da populaçáo, desde brancos até índios, ${ }^{8}$ alguns alcançando significativo destaque e respeito na vila, como o entalhador e Tenente Bento José de Souza, responsável pela execução de vários retábulos.

Da mesma maneira que em São Paulo, em Vila Boa a Câmara foi legalmente a maior responsável pelo controle de seus artesãos. ${ }^{10}$ Os oficiais, ao saírem para Correição, buscavam verificar as condiçóes de trabalho dos profissionais mecânicos e aplicar multas naqueles que se encontravam sem licenças ou Cartas de Exames. ${ }^{11}$

No entanto, a fragilidade do sistema perdurou até o final do Setecentos, como se vê no registro de documentos e no Termo de Vereança de 15 de novembro de 1792: "o juiz ordinário actual e Prezidente da mesma [ da Câmara] o Capitão José de Lima Fonseca, os Vereadores Capitão Pedro Monteiro da Silva, o Sargento-Mor Álvaro José Xavier da Silva e o Procurador actual Manoel José Leyte commigo Escrivão ao diante nomeado sendo alli sahirão de Correiçáo Geral por toda as ruas desta Vila... E por elle foi requerido que as pessoas do rol que apresentavam, humas não tinham licenças, outras não tinham aferido, e por isso requeriam fossem condenadas, como também alguns officiais de officio mechanico não tinhão carta de exame (...)"12

A estrutura administrativa e burocrática e, conseqüentemente, de controle dos artesáos goianos aproximava-se da de São Paulo. Nessa Capitania, Maria Helena Flexor ${ }^{13}$ constatou a existência de

8 Embora a Ordenaçáo Lusa tivesse proibido a participaçăo de oficiais mecânicos em serviç̧os públicos, essa năo foi uma realidad para a vila goiana, que contou com a presença de militares que exerceram oficios de mestres carpinteiros, pedreiros e arruadores this como os capitáes Antoric de Souza Telles e Menezes, Antônio da Silva Pereira, Antônio Jozé do Valle e o arruador Manu Ribeiro de Guimarăes.

9 "Conta corrente das partes do ouro que eu Bento Jozé de Souza, ganhei, pela minha arte de Pintor, nesta Villa Boa, de que tomava a sy o Sr. Antônio Jozé de Souza, meu pay, que Deus tem guira, por quaes parcelas se unityor

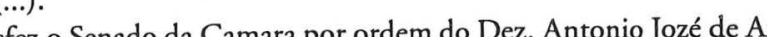
$128 / 8$

Pros Arquivo Frei Simáo Dorvi. Documento avulso de 1765. Cidade de Goís.

10 "Em 1741 último ano de que se conservam registros especificados da capitaçăo, havia em todo território de Goiás 146 mestres e 131 oficiais, quase todos instalados em Vila Boa". PALACIN, Luis. O século do ouro em Goids. Goiânia: Editora da UCG, 1994. p. 74 .

${ }^{11}$ Estando devidamente habilitados, os artesāos podiam abrir suas lojas ou tendas, fiscalizadas por impostos aplicados pel Câmara e regulamentados pelas Licenfass, Cartas e Fiannfas, para a exploraçăo de suas atividades, os Regimentos.

Arquivo Frei Simão Dorvi. Termo de Vereanşa de 15/11/1792. Documento avulso. Cidade de Goiás.

13 FLEXOR, Maria Helena. Op. cit., p. 140-143. 
uma débil organizaçáo, mais preocupada com as taxas que regulamentavam as atividades profissionais do que propriamente com as irregularidades dos artesãos e, especificamente, com a qualidade das obras.

O período colonial brasileiro também conheceu uma legislação que regulamentava o exercício profissional dos artesãos. Segundo Myriam de Oliveira, todo oficial era obrigado a fazer exame, que "consistia tradicionalmente na confecçáo de uma ou mais obras próprias do ofício do candidato, chamadas "peças de examinação", sistema que tem sua origem nas "obras primas" medievais. Nos ofícios relacionados com as construçôes, notadamente os de pedreiro e carpinteiro, a principal matéria dos exames era contudo uma prova de conhecimentos teóricos, acompanhada, nos primeiros tempos da execução, pelo examinado de peças arquitetônicas como escadas, portais e colunas." ${ }^{14}$

Com a posse da carta, o profissional passava à categoria de mestre. Antes, porém, devia registrá-la, pedir sua confirmação na corte, prestar juramento prévio para desenvolver bem suas atividades, pagar as licenças e apresentar fiador. Só então podia instalar suas tendas ou "loje", ou exercer suas funçôes publicamente. $O$ profissional que não atendesse a essas exigências era punido com multas estabelecidas pelas Câmaras. Assim, a posse desse documento era a garantia legal do exercício profissional de várias atividades, excetuando-se as dos entalhadores, escultores e pintores, consideradas profissōes mais artísticas.

No que diz respeito aos exames feitos em Vila Boa, certamente refletiram as mesmas fragilidades presentes no controle dos profissionais. Até porque não se tem notícia de que a regiáo contasse com artesãos altamente qualificados e juízes de ofícios. Limitou-se apenas a um reduzido número de mestres que, em muitos casos, exerciam mais de uma atividade.

\subsection{O CONTROLE DAS CONSTRUÇŌES}

O controle das construçôes do Brasil Colonial foi feito basicamente em duas instâncias: a primeira, profissional, contava com os cargos dos "juízes de ofício" e os regulamentos dos regimentos, que existiam em todas as cidades e vilas; a segunda dirigiu-se mais diretamente às obras e foram avaliaçōes, peritagens, contratação ou louvaçôes. Em Vila Boa, as fiscalizaçōes de serviços públicos $\mathrm{e}$ religiosos foram exercidas pela Câmara. Essa, no entanto, por não contar com juízes de ofícios em seu quadro administrativo, freqüentemente convocava profissionais carpinteiros, pedreiros e arruadores para realizar mediçōes, vistorias e avaliações, como se observa nessa nomeação:

Os avaliadores dos bens móveis e de raiz e, foráo eleitos os seguintes para os móveis José de Nogueira da Cruz e Luiz Lourenço Pedras e para os de raizes José Lopes de Barros, e Geraldo Fernandes de Oliveira [carpinteiro], digo Antônio Monteiro Varella. ${ }^{15}$

${ }_{14}$ OLIVEIRA, Myriam Andrade Ribeiro de. Op. cit., p. 167

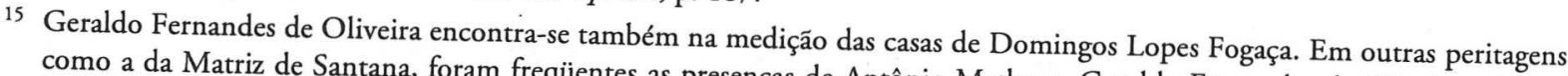
Fernandes Lima, Matheus da Silva. Arquivo Frei Simäo Dorvi. Termo de Vereannfa O2/01/17993. Documes de Oliveira, Manu Goiás.
As avaliaçóes, entáo, foram as práticas mais habituais para o controle das construçóes, como a que foi feita no fim da rua chamada de Pallacio: "o Douttor Ouvidor Geral Manoel Antunes da Fonseca foi com o Juiz Ordinário, Joze de Godoy Roâ, e o vereador Bacharel formado Joáo Ferreyra de Barros e o procurador da Câmara Manoel de Lima Soutto, e junto com elle o arruador Manuel Fernandes Lima, (...) Manuel de Souza Bagunte, para efeito de se examinar, e medir, a distância que sem cazas medea, do fim da ditta Rua até a Cadeia e Casa de Camara (...)"16

No controle das construçóes religiosas, como a matriz de Santana, houve avaliações nos autos de arbitragem realizados por ordem do provedor, que convocou "(...) quatro mestres, dois carpinteiros Manuel Fernandes Lima e Antônio Matheus; e Matheus da Silva mestre de pedreiro com Paulo Marques também mestres(...)", ${ }^{17}$ para identificar se $\mathrm{o}$ andamento dos trabalhos estava conforme às especificaçóes previstas em planta e risco e se havia compatibilizaçáo orçamentária para a obtençáo dos recursos necessários para a conclusão da obra.

Em relação às demais capelas, o controle limitou-se particularmente às demarcaçôes dos principais espaços dos edifícios, como o adro, arco-cruzeiro e altar, feito por um juiz representante da câmara.

O sistema estava diretamente relacionado à importância social de cada uma das construçôes. As capelas contavam praticamente com a marcação e aferição das obras, visando a atender às normas previstas pela legislação. A matriz teve um controle muito mais sistemático e eficaz, com constante envolvimento de peritos e avaliadores que, direta ou indiretamente, responsabilizaram-se pela qualidade da obra.

A contratação de profissionais através das arremataçōes ${ }^{18}$ foi também um importante procedimento que interferiu diretamente na qualidade dos edifícios. Através delas, eram selecionados os melhores profissionais e preços, correspondendo a um momento simbólico e decisivo para a execuçáo dos serviços. Iniciava-se quando "se determinava [que] se puzesse em Praça [os serviços] (...) para se rematarem a quem por menos o [fizesse] fora com a brevidade possível". ${ }^{19}$

${ }^{16}$ Arquivo Histórico Ultramarino. Cx. 4, Doc. 300, Lisboa, Portugal.

17 "Auto de arbitramento feito nas obras da nova Igreja Matriz desta Vila Boa, sobre a despeza de que necessita. Para ficar coberta "Auto de arbitramento feito nas obras da nova Igreja Matriz desta Vila Boa, sobre a despeza de que necessita. Para ficar cobberta Simăo Dorvi. Auto de Arbitramento. Documento avulso de 1744 . Cidade de Goiás.

18 "Ach-se vencido (a) o utimo pagmento do que deve o rematante da affliaço e como năo tem cumprido aos pagamentos como era obrigado, para se pagarem as orandes despezas que se tem feito com a pedreira, calcadas, concerto da fonte, caminhos, e o mais que por esta Camara se tem mandado fazer, como consta dos Livros da Vereança; secravos alugados a quem se mandou o mais que por esta Camara se tem mandado fazer, como consta dos Livros da vereança; escravos alugados a quem se mandou
pagar os jornais. Requeiro se pague manda o de seqüestro contra o Rematante pela quantia da sua Remataçäo, com o pretexto

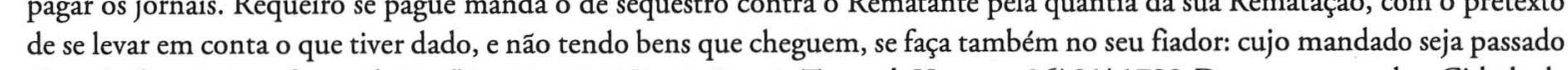
clausula de prisāo na forma da Ley."Arquivo Frei Simáo Dorvi. Termo de Vereanşa 06/ $01 / 1792$. Documento avulso. Cidade de Goiás.

Doc. Estabeleceu-se pelas mesmas ordens serem arrematados os Contratos, Oficios, Obras e tudo o mais que se costumava fazer por arremataçóes da Fazenda Real, como da Casa de Fundiçăo desta Vila do dito Tribunal (...). Relatório da Real

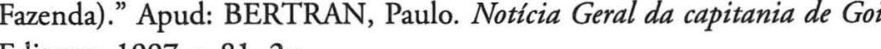

"Os que săo de obras que se arrematam fazem Requerimentos sucintos e outras vezes juntando-lhe documento de teren

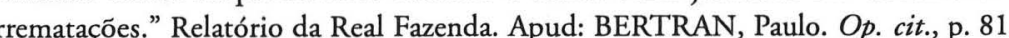

19 Arquivo Frei Simão Dorvi. Documento avulso. Cidade de Goiás. 
Colocar em praça correspondia ao momento de divulgação e contratação do empreendimento, cujo intuito era o de encontrar melhores ofertas nos preços dos serviços. "A adjucação ocorria geralmente um mês depois [ de colocar em praça], sendo anotada num livro de termos que mencionava todos os detalhes dos trabalhos a serem feitos. A proposta mais vantajosa era aceita e seu proponente nomeado arrematante" ${ }^{20}$ Como garantia, o arrematante apresentava um fiador que se responsabilizava pelo serviço, caso houvesse imprevisto. Após o término, ou em caso de alteraçôes nas obras, realizavam-se as louvaçóes, escolhendo-se um profissional, de comum acordo de partes, para fazer a avaliaçăo final.

As adjucaçōes, normalmente, eram feitas para as diferentes etapas de trabalhos, contando com a presença de vários arrematantes. "Havia uma adjudicação para as obras de alvenaria e uma outra para as de carpintaria, que começava quando a construçáo já estava pronta. Depois, ainda vinham as adjucaçóes diversas, como a talha, que era feita por peça, quando se tratava de uma igreja de numerosas confrarias e, finalmente, o mobiliário, a mercenária, a serraria etc." ${ }^{21}$ Um único arrematante não conseguia acertar o conjunto de todos os serviços, como no caso da arremataçáo da porta principal da Matriz, que se fez "de empreitada por quatrocentos oitavas, não entrando, a conduçáo da pedra, nem o arrancamento della. E com todo o referido (...) como posso satisfazer a informaçáo mandada dar por V. Magestade que sempre ordenará o que for mais de seu agrado. ${ }^{22}$

Náo havendo adjucaçóes, os profissionais eram contratados diretamente pelo erector. De acordo com Germain Bazin, essa foi a forma de assegurar a participaçáo de algum empreiteiro mais qualificado, que recebia como mestre-de obras. Paralelamente às arremataçóes, decidia-se como seriam pagos os serviços prestados - por regime de jornada, empreitada ou subempreitada -, firmados por contratos ou "termos de ajustes". Nesses, apresentavam-se as descriçôes de acerto dos honorários, especificações gerais de materiais e a garantia de execução conforme risco e planta.

Um dos últimos procedimentos de controle das igrejas de Vila Boa encontra-se nos seus erectores e mestres-de-obras. Esses eram os que assumiam definitivamente o andamento e a execuçáo das construçôes. Em todas elas, identifica-se a freqüente presença de um conjunto de profissionais que se responsabilizava pelos aspectos técnicos das obras, coordenadas por um erector, fosse ele um particular ou uma associaçáo leiga, seguido por um mestre-de-obras, responsável direto pelas tarefas práticas no canteiro.

No conjunto dessas formas de fiscalização e controle das construçôes coloniais, observam-se estruturas organizacionais de grupo de profissionais articuladas entre si, que envolviam desde a Câmara, com peritos e avaliadores, até os erectores e mestres de diferentes categorias que, reunidos, constituíam um coordenado esquema de trabalho.

No caso de Vila Boa, a partir da segunda metade do século, as fiscalizaçôes e avaliaçóes foram feitas por importantes profissionais peritos, tais como Manuel de Souza Bagunde, Manuel Fernandes

$\overline{{ }^{20}}$ BAZIN, Germain. A arquitetura religiosa no Brasil. Rio de Janeiro: Record, 1986, p. 49.

${ }^{21}$ BAZIN, Germain. Op. cit., p. 49

${ }^{22}$ Arquivo Frei Simăo Dorvi. Auto de Arbitramento de 1744. Documento avulso. Cidade de Goiás.
Lima, Matheus da Silva, Geraldo Fernandes de Oliveira, Antônio Matheus e outros. ${ }^{23}$ Esses profissionais atuaram como avaliadores em diferentes trabalhos e em diferentes especialidades, desde intervençōes urbanas até marcaçốes de edifícios religiosos, públicos e particulares, a saber: Matriz de Santana, Casa de Câmara e Cadeia, consertos e avaliaçóes em várias casas e Casa de Fundiçáo. Eram, provavelmente, os profissionais mais habilitados da Vila e, portanto, os maiores detentores de conhecimentos e técnicas construtivas.

Quanto aos canteiros de obras, sua organizaçáo fundamentava-se em esquemas hierárquicos de coordenação de diferentes profissionais, formas que tinham suas raízes nos tradicionais estaleiros portugueses, ${ }^{24} \mathrm{e}$ na figura dos vedores ou juízes de obras, responsáveis por transmitir as decisóes dos erectores e fiscalizar os mestres gerais, que asseguravam a ordem dos profissionais e a sequiência das inúmeras tarefas a serem realizadas.

Nessa organizaçáo, o erector era o maior responsável pela qualidade e unidade dos edifícios, ao providenciar os recursos financeiros e a contratação das equipes de trabalho. Ao mestre, cabiam a responsabilidade do acompanhamento efetivo das construçóes, discussóes gerais sobre os procedimentos construtivos, trocas de informaçōes e modificaçóes do empreendimento. Assim, todo o processo de trabalho distribuía-se em etapas, que iam desde as soluçôes relacionadas ao arcabouço do prédio até a execução de detalhes, como os altares-mores, portadas, púlpitos e pinturas de teto.

Em Vila Boa, o esquema mais elaborado de trabalho em canteiro de obras foi o da Matriz de Santana. Além das freqüentes vistorias por grupos de profissionais que visavam a "examinar a obra feita na nova Matriz desta Villa, e arbitrar a despeza do que se necessitava athé ficar acabada a dita Igreja coberta de telha, com portas fechadas (...).", ${ }^{25}$ a Câmara, conjugada com a Irmandade do Santíssimo, exerceu a função dos "vedores" portugueses e manteve os intercâmbios com a coroa, informando-a freqüentemente sobre o desenvolvimento dos trabalhos e gastos com a construçáo. Portanto, foi a interlocutora e a responsável pelas modificaçôes, qualidade e unidade geral da obra, na medida em que a acompanhou ou solicitou-lhe novos recursos.

23 "Manuel de Souza Bagunde, Manuel Fernandes Lima, Matheus da Silva, Geraldo Fernandes de Oliveira, Antônio Matheus, mestre carpinteiro de obras, e por elles ditto que havendo (...) medir e avaliar as sinco moradas da cazas de que se trata no Termo (...) e consertos na Casa de Fundiçäo. Arquivo hris e Goiás.

Geraldo Fernandes de Oliveira Matheus, Manuel Fernandes Lima e Matheus da Silva, Antônio Matheus todos moradores desta vila Mestres carpinteiros de obras: logo ahy pello dito Ministro se foi deferido juramento dos Santos Evangehos debaixo que na mesma tem Domingos Lopes Fogaça todas contíguas humas e outras a saber (...)" Arquivo Frei Simão Dorvi. Termo de Vereanga de 12 /09/1792. Documento avulso. Cidade de Goiás.

${ }_{24}$ "Na base da pirâmide estavam os cabouqueiros, que tinham um vedor próprio, pedreiros, aparelhadores, assentadores e carreiros, obreiros que forneciam material diretamente para as obras, como os ferreiros, os carpinteiros, a que se juntavam mesteirais, cuja funçăo era manter vivo todo aquele organismo; entre estes contam os padeiros, barbeiros, alfaiates, enfim todos os oficios indispensáveis nesta ou em qualquer vila do tempo (...).

Além desses homens, outros, externamente ao estaleiro, auxiliavam os trabalhos sob a dependência do "vedor", como os carreiros que transportavam a pedra, a madeira e o restante dos materiais. Contavam ainda com escrivaes, apontadores, fiscais e guarda de armazéns. No entanto, todo o sucesso da obra era garantido pelo controle dos mestres gerais ou arrematantes que formas. Lisboa: Editorial Estampa, 1995. p. 26-27.

25 "Auto de arbirrmento feito nas obras de nova Ireja Marriz desta Villa sobre a despeza de que se necessita, para ficar coherta "Auto de arbitramento feito nas obras da nova Igreja Matriz desta Villa sobre a despeza de que se necessita, para ficar coberta "de telha, com chaves nas portas, com declaraçăo da despeza que bastaria para a factura da Capell la-Mor." Arquivo Frei Simăo 
Da metrópole, vieram os recursos e as indicações de cuidados especiais para a sua execução, através de especificaçóes previstas no novo risco. No entanto, a despeito dessas preocupaçóes, a construçáo do edifício se desenvolveu com várias alteraçōes de natureza econômica e construtiva. Muitas foram as decisóes de ordem contábil, sinalizando freqüentes preocupaçóes com os gastos excessivos, apesar de uma certa preocupaçáo com o acabamento da obra. ${ }^{26} \AA$ coroa coube, particularmente, a doaçáo do plano e recursos para a construçáo da capela-mor. O restante foi deixado aos encargos da Câmara, cujas questôes de ordem econômica provavelmente interferiram no resultado final do empreendimento.

Em relação às demais capelas, não houve uma estrutura de organização tão bem articulada como no caso da Matriz. Além de serem edifícios de menor importância, foram erguidos por encomendantes particulares, que não dispunham dos mesmos recursos técnicos e financeiros dos erectores de Santana. No entanto, seus canteiros guardam a mesma estrutura. Suas organizaçôes, embora limitadas basicamente aos profissionais ligados diretamente à construção, eram também coordenadas por mestres que assumiam distintas fases da obra, como se vê no documento da Irmandade Nossa Senhora do Rosário, informando a presença de uma equipe de trabalhadores composta por "29 negros que trabalharão aos cinco dias com os officiais, cujo forão de Me. Gomes." ${ }^{27} \mathrm{O}$ que distinguiu os procedimentos construtivos das pequenas capelas e da Matriz de Santana foram a qualificaçăo dos vários artífices e o sistema de controle das obras, considerados mais frágeis e débeis que os das obras de maior importância.

Por fim, ainda em função das formas de controle dessas igrejas vilaboenses, o seu processo construtivo, diferentemente do da Matriz, caracterizou-se por várias intervençóes pontuais, provenientes de trabalhos executados em etapas muito distantes umas das outras, resultando numa arquitetura sem completa unidade formal construtiva, como no caso da Igreja Nossa Senhora da Boa Morte, iniciada em 1762 pelo capitão de cavalaria Antônio da Silva Pereira e, posteriormente, entregue à Irmandade dos Pardos, que a concluiu em 1779. Construída ao longo de dezessete anos, acolheu diferentes grupos de profissionais, que a marcaram com intervençōes pontuais, responsáveis por soluçóes formais muitas vezes descontínuas, sem unidade estilística clara.

\subsection{A EDIFICAÇÃO E A CONCEPÇÃO DAS IGREJAS}

Em $A$ iconografia dos engenheiros militares no século XVIII: instrumento de conbecimento e controle de território, ${ }^{28}$ Beatriz P. Siqueira Bueno chama a atenção para a importância dos desenhos na compreensão de algumas dimensões da cultura colonial, dentre elas a da arquitetura. Assim, com uma observação mais cuidadosa sobre as "traças", podem-se entender melhor os valores artísticos dos construtores das igrejas setecentistas de Vila Boa e reconhecer as suas práticas e instrumentos construtivos.

${ }^{26}$ No auto de arbitramento encontram-se as informaçoes sobre os gastos com a Matriz e a preocupaçăo em se manter a qualidade da obra, em especial, a do altar-mor. Arquivo Frei Simăo Dorvi. Documento avulso. Cidade de Goiás.

${ }^{27}$ Arquivo Frei Simáo Dorvi. Termo de Meza de Nossa Senhora do Rosário de 1759. Documento avulso. Cidade de Goiás

28 BUENO, Beatriz P. S. "A iconografia dos engenheiros militares no século XVIII: instrumento de conhecimento e controle
É difícil a distinção dos conceitos de traça, risco ou de outras formas de representação arquitetônica na literatura que trata da arte colonial brasileira, porque comparecem habitualmente como sinônimos, tornando-se ambíguos e impedindo interpretaçóes mais seguras.

$\mathrm{Na}$ tradicional historiografia brasileira, as traças são comumente tomadas por traçados, desenhos e plantas de uma obra ou construçáo. Riscos são desenhos gerais, prospectos ou planos de uma construção, de um retábulo ou de alguma obra.

No Dicionário da Arquitetura Brasileira de Corona e Lemos, ${ }^{29}$ risco é colocado como sinônimo de projeto, istó é, designando o desenho original concebido pelo arquiteto ou mestre de obras.

Com Lúcio Costa, a explicação da palavra risco volta à etimologia do vocábulo, visando a entender não tanto ao que ela se refere, se planta, elevaçáo, prospecto etc, mas o seu caráter ou natureza:

O risco na sua acepçăo antiga está sempre associado à idéia de concepçáo ou feitio de alguma coisa, enão desenho visando à feitura de um determinado objeto ou à execuçăo de uma determinada obra. $^{30}$

Segundo esses conceitos, o significado da palavra risco aproxima-se do de traça e, conseqüentemente, do de projeto, não sendo possível esclarecer a existência de fronteiras interpretativas entre as variadas denominaçóes que essas expressōes assumiram. Nesse sentido, as comparaçóes etimológicas e as leituras de textos de época podem ajudar a superar possíveis equívocos e constituírem-se em eficazes instrumentos de compreensão de concepçóes arquitetônicas.

Quanto ao vocábulo projeto, Beatriz Bueno ${ }^{31}$ assinala sua ausência na Língua Portuguesa antes do final do século XVII. E em relaçáo às palavras risco, debuxo, traça, amostra, afirma que eram empregadas para designar o que hoje se entende por representaçáo gráfica..$^{32}$ De todos esses termos, 0 desenho, "era o exercício intelectual que precedia a realização das "obras que têm invençăo, ou forma, ou fermosura, ou proporção". Não se tratava de qualquer exercício intelectual, à medida que pressupunha o domínio da aritmética, da geometria e do sistema das proporções que envolvia a concepção das fortificaçóes à maneira italiana, das obras châs, das cidades de traçado regular ou tendencialmente regular».33

Essa fragilidade nas definiçóes terminológicas pode estar associada aos vários sentidos que a palavra trą̧a incorporou nos séculos XVI eXVII, posteriormente eclipsada por aquilo que Fernando Marías denominou de visão italianocêntrica da historiografia arquitetônica contemporânea. Essa visão italianocêntrica gerou o desconhecimento de um tipo de desenho que não foi, exclusivamente, movido por parâmetros renascentistas, mas pelos seus vínculos com uma longa tradiçăo de difícil interpretaçáo

29 CORONA, Eduardo e LEMOS, Carlos. Dicionário da Arquitetura brasileira. Săo Paulo: EDART, 1972, p. 414.

${ }_{30}$ COSTA Lúcio "A arquitetura de Antônio Francisco Lisboa". In: Lúcio Costa regisstro de uma vivência. São Paulo: Empresa das Artes, 1995. p. 539

BUENO, Beatriz P. S. "Desenho e desígnio: O Brasil dos engenheiros militares (1500- 1822)." Comunicaçăo apresentada no Congresso ICAM. Rio de Janeiro, maio 21e 25, 2000, s/n.

32 BUENO, Beatriz. Op. cit., s/n.

- ${ }^{32}$ BUENO

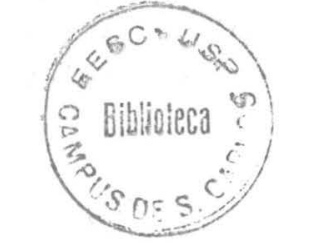


e aceitaçăo. Apresentavam-se, fundamentalmente, em forma de testemunhos de receitas, como unidades de prontuários, modelos compositivos mais do que composição de conjunto. ${ }^{34}$ Seus valores residiam na estreita proximidade que estabeleciam com o resultado final do edifício construído.

O significado de traça, na tradiçáo espanhola, evidencia tipos de desenhos que estiveram associados a um determinado fim, a execuçáo de obras, relacionados mais especificamente a problema "técnicos construtivos":

De um ponto de vista funcional, a traça da planta de um edifício, em que se expressavam as proporçóes estáticas entre cheios e vazios - contrafortes, arcos e paredes estruturais, ou a seção na qual se dispunham de forma ordenada as relaçốes entre apoios e aberturas, passaram a ter uma importânci fundamental e constituir, para outro de arquiteto e arquitetura, o núcleo básico de sua atividade como profissionais da ciência construtiva, não apenas da arte da ornamentação.

Fernando Marías ainda assinala a ambigüidade que a expressão assumiu historicamente, chamando a atenção para o cuidado de se buscarem interpretaçóes do termo em fontes documentais da arquitetura do passado, pois ele se estendia a diversas práticas construtivas.

Em Portugal, Paulo Pereira afirma que a prática construtiva lusitana tradicional também se utilizava de uma grande variedade de trą̧as destinadas a diferentes fins, configurando um quadro de uma cultura arquitetônica absolutamente paralela à da Espanha. Por isso, considera, para Portugal, as mesmas observaçóes do seiscentista espanhol Gil de Hontañon sobre a situação da arquitetura naquela época.

Muchos modernos llaman a estos 5 generos arquitectura y a los demas traça, no entendiendo que este es uno de los sirbientes de la cosa mas no la cosa (...) Porque no dejaria de ser uno por no ser guarneçido de seda, adornale y açele rico, mas sin aquella costa ni gastos se podria pasar, com un templo sin vasas, ni capiteles, ni cornijas, y no dejaria de ser templo. Algunos, porque fue traduçido el $1 / 3$ y el 1/4 [libros] de Sebastian [ Serlio], y an leydo de como se deve açer una columna, diçen qye aquello es la çiencia y lo demas es el arte $(. .)^{35}$

Com esses dados, pode-se dizer que as traças em Portugal referem-se a desenhos esquemáticos, ligados a uma tendência construtiva que não se caracterizava por uma resolução "integral" da obra. "A arquitetura é a traça com suas regras gerais; o resto é adicionado" ${ }^{36} \mathrm{O}$ que importava eram os princípios da concepção do edifício, com os demais detalhes feitos a partir de desenhos parciais, correspondendo a práticas construtivas diferenciadas. Foi essa a lógica construtiva dos séculos XVI e XVII, que persistiu, no meio cultural classicista, com o acompanhamento de "desenhos" aos quais Fernando Marias chamou de "trą̧a sem estilo," e, em Portugal, Paulo Pereira associou ao desenho do 34 FRANCO, Fernando Mariass. "Trazas, trazass, trazass: tipos y funciones del dibujo arquitectónico." In: Juan de Herrera y su
influencia. Actas del simposio. Camargo, 1992. p.351

Apud: PEREIRA, Paulo "A traça como único princípio." In: Estudos de Arte e Historia. Homenagem a Artur Nobre de Gusmáo
Lisboa: Veja, 1995. p. 197.

${ }^{36}$ HONTAÑON, Rodrigo Gil de. Apud: PEREIRA, Paulo. Op.cit., p. 197. "estilo chão". Nos séculos XVI e XVII, muitos mestres defendiam a "traça sem estilo," por considerarem mais seguros os princípios tradicionais dos antigos estaleiros consagrados pelo tempo.

No Brasil, cidades e vilas brasileiras conheceram desenhos similares aos do "estilo chão", adaptados a diferentes realidades. Seu caráter pragmático atendeu às necessidades e carências de regiōes coloniais e visou a dar respostas mais imediatas aos problemas de natureza técnico-construtiva. São Paulo, Minas Gerais e Goiás exemplificam esses locais onde, junto ao tradicional processo construtivo, seguia o correlato recurso às traças. Porém, essas representaçōes gráficas parecem ter assumido variadas configuraçóes, mais elaboradas ou mais simplificadas. Em alguns casos, ao se adequarem às condições locais, simplificaram-se a esquemas mínimos, validando-se, basicamente, pela marcação de medidas gerais em plantas e elevaçóes.

Particularmente em Goiás, fontes manuscritas apontam para o freqüente recurso a desenhos, utilizados tanto em simples casas ${ }^{37}$ como em edificaçóes de maior importância, a exemplo das Matrizes de Santana e Traíras ${ }^{38}$ e da Casa de Câmara e Cadeia. No mais, por certo houve traças para Nossa Senhora da Boa Morte, Nossa Senhora do Carmo, chafariz, arcos e retábulos de algumas capelas, dadas as qualidade e complexidade dessas obras.

Para as demais capelas, São Francisco de Paula e Nossa Senhora da Abadia e, provavelmente, Nossa Senhora do Rosário, só persistem as diretrizes básicas para a marcação de pontos gerais, como os que foram indicados para Santa Bárbara.

(...) para o effeito de assignar o lugar em que há de erigir a capella da gloriosa Santa Bárbara, a requerimento dos devotos da mesma santa, em presença do mais povo que servirão de testemunha $\mathrm{e}$ vão assignadas abaixo, a que tudo visto se precedeu à mediçăo e demarcaçăo no respectivo logar em plano que se há de fundar a dita capella com o seu Adro o qual consta de 15 braças de comprimento e dez de largo; para o que se puzeram os marcos e se assentou uma cruz no logar onde havia de ficar o altar (..... ${ }^{39}$

Através de algumas fontes iconográficas de São Paulo e Mato Grosso, regiōes que apontam para um quadro cultural semelhante ao de Goiás e que mantiveram fortes laços de comunicaçáo com Vila Boa, é possível identificar algumas das características dos desenhos vilaboenses.

Antes porém, cabe lembrar, seguindo Germain Bazin, que, entre as especialidades dos construtores, não se identifica nenhum ofício ou profissional que se dedicasse exclusivamente à execução de desenhos. ${ }^{40}$ Eles poderiam ser feitos por qualquer pessoa que tivesse adquirido conhecimento de arquitetura prática ou tecnicamente pela competência de engenheiros. Em Minas Gerais, foram freqüentemente oferecidos por pedreiros, carpinteiros, entalhadores, pintores, padres e militares de

\section{㽚}

37 "as ditas moradas novas pella planta e risco destas, continuando-se o mesmo acréscimo dellas convendo-lhes fazer para a parte da ditta rua a mesma frente e aparencia que as novas para o ditto Largo inclúndo-se no tal acréscimo os repartimentos que se julguem poiás.

${ }_{38}$ Tráras, antigo arraial do ciclo da mineraçăo do Julgado do Norte da Capitania de Goiás.

39 Arquivo Frei Simăo Dorvi. Documento avulso de 1775. Cidade de Goiás

¿ 40 BAZIN, Germain. Op. cit, p. 43. 


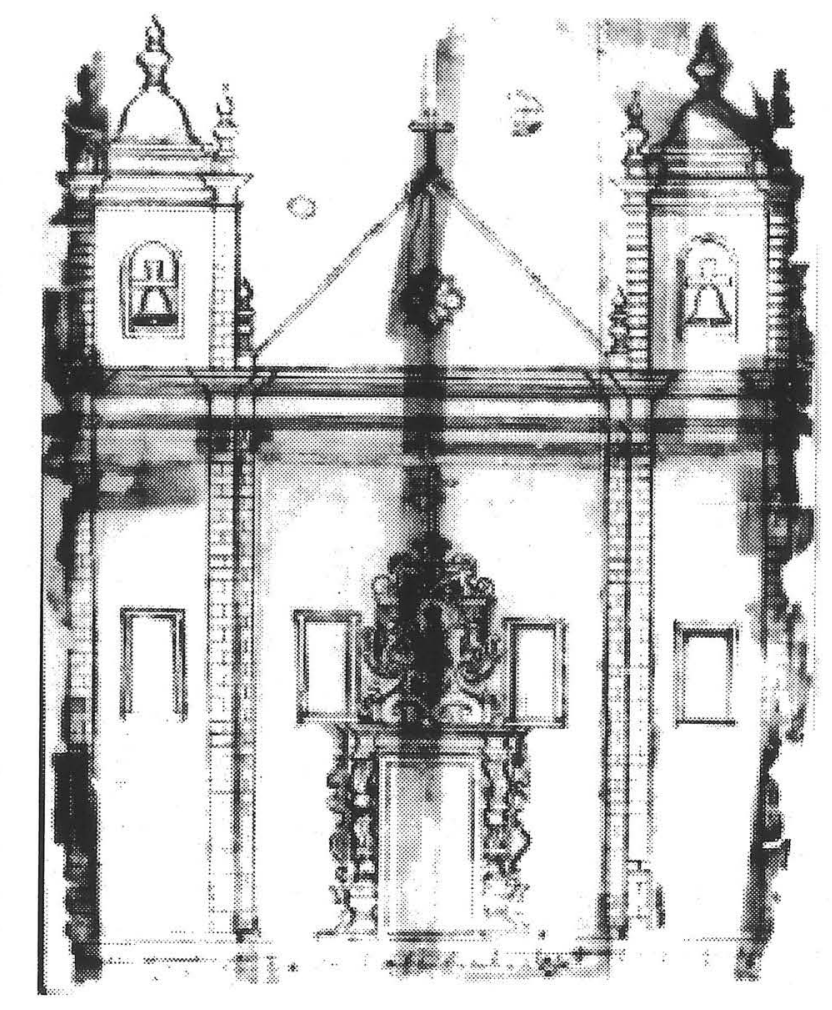

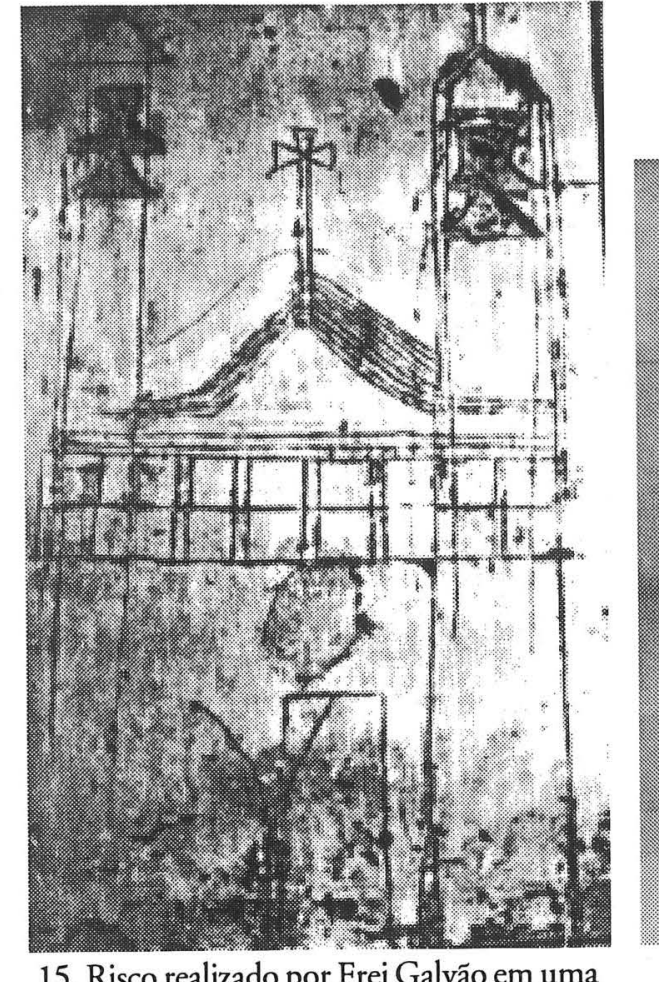

15. Risco realizado por Frei Galvão em uma parede do mosteiro - São Paulo. paulistanas de planta octogonal". Revista da

$$
\text { USP, 1986)) }
$$

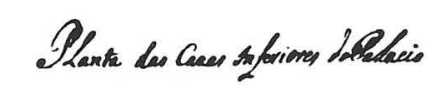

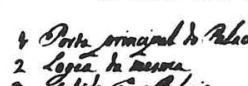

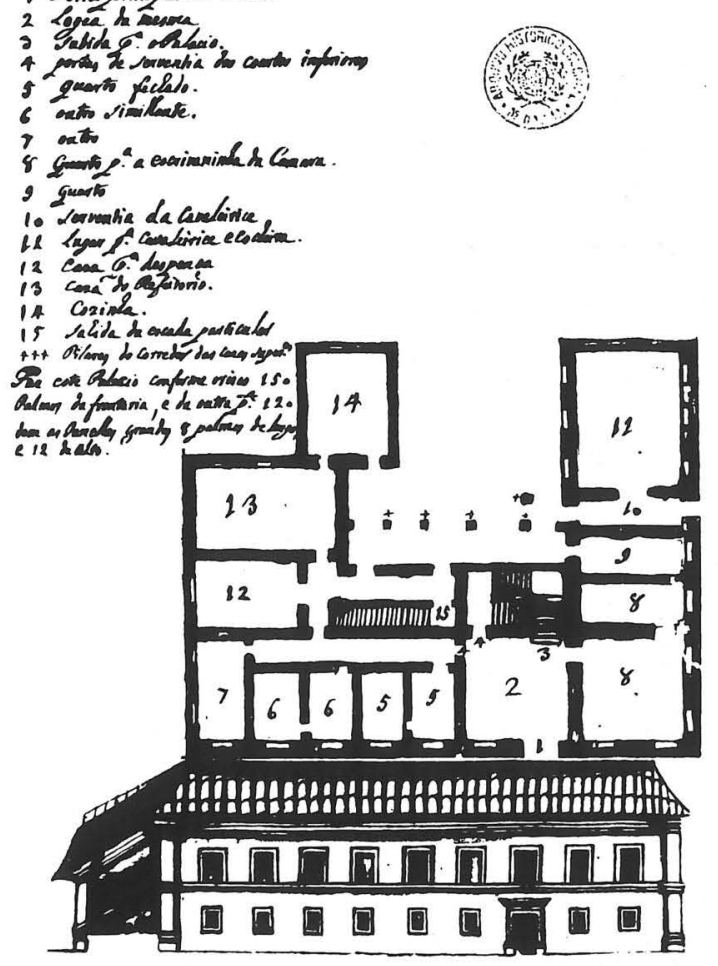

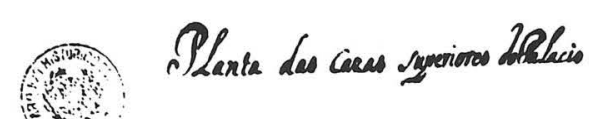

in

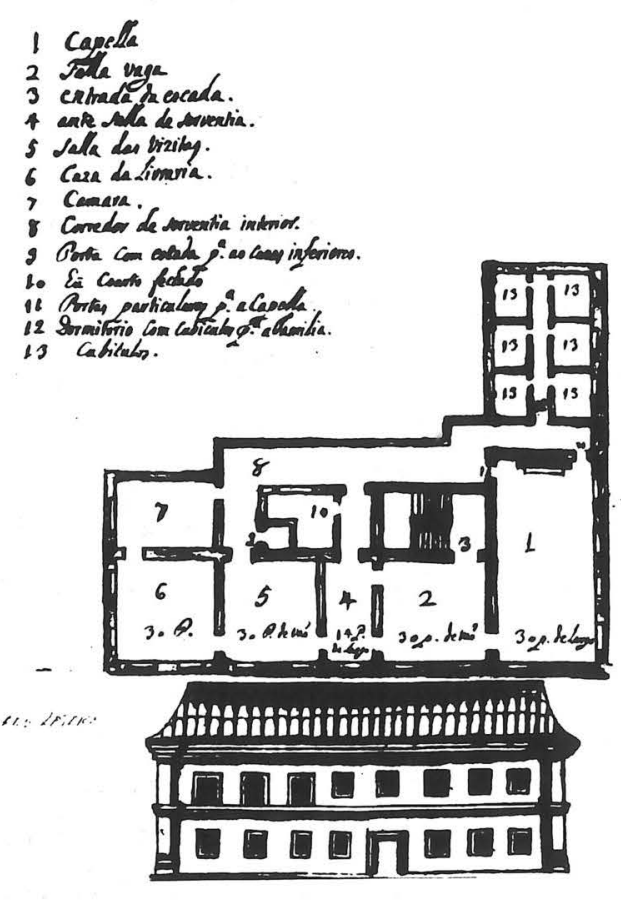

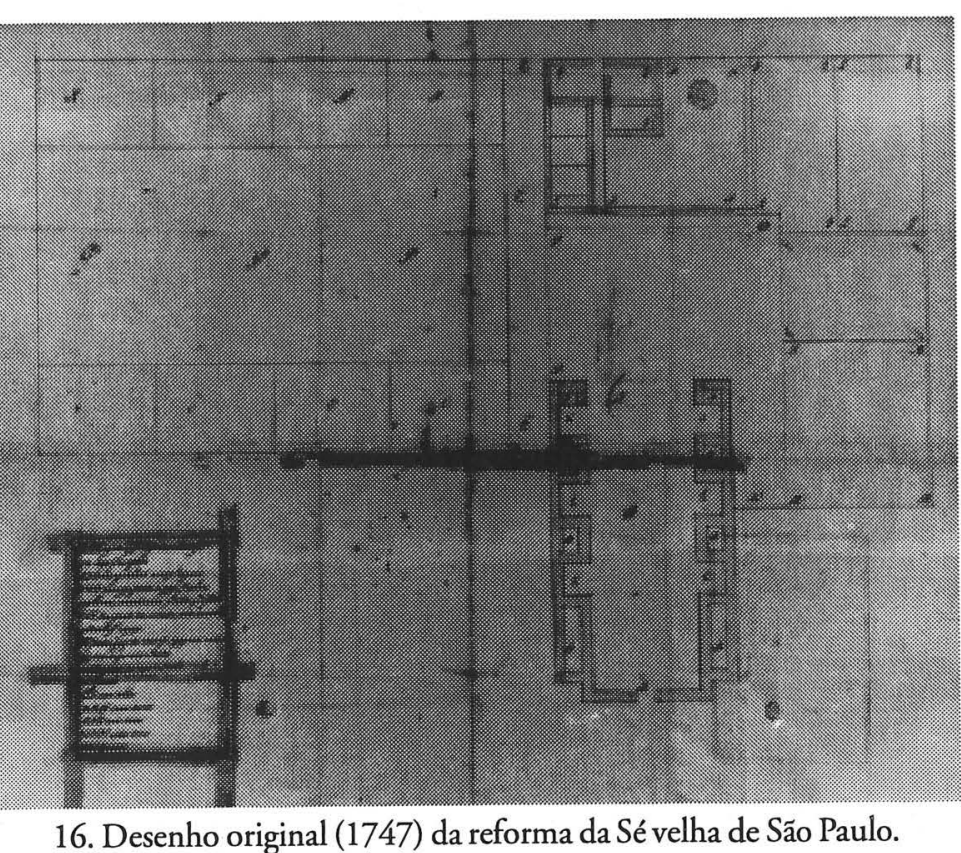
(Original Arquivo Histórico Ultramarino de Lisboa) 


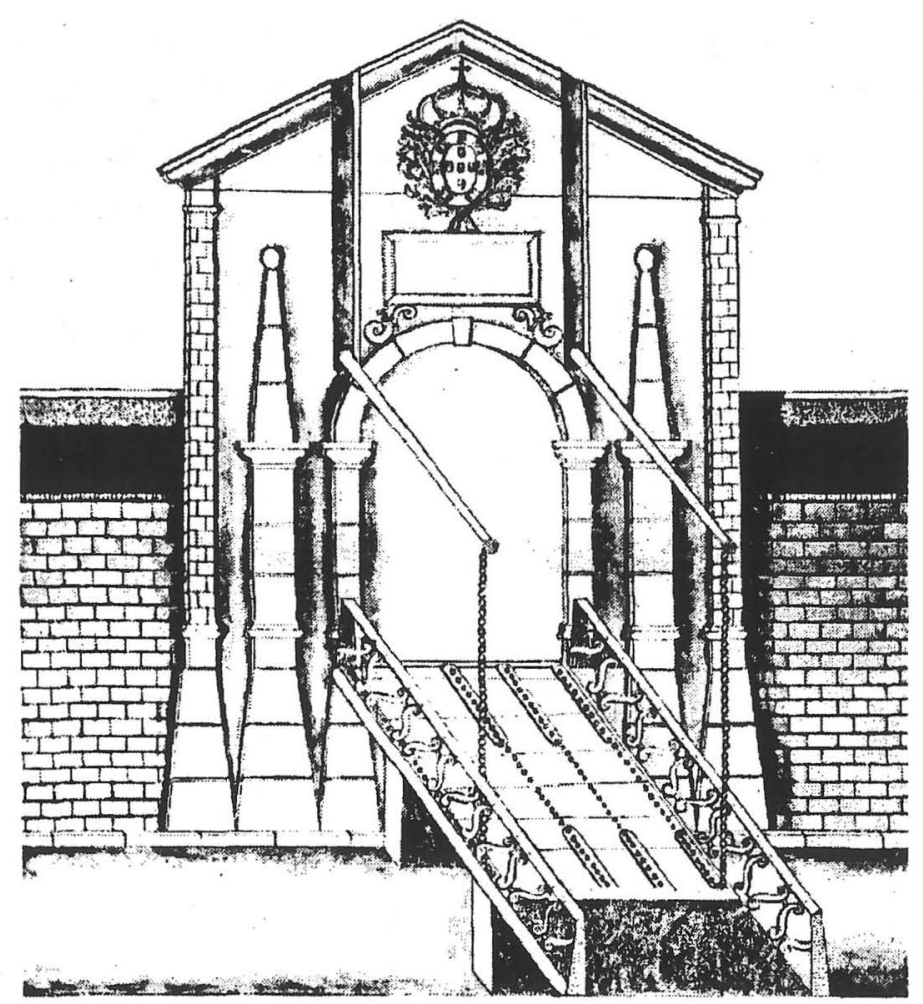

18. Desenho, em alçado, do portal de entrada do Forte Príncipe da Beira em Rondônia. Original: Casa da Ínsua. (FARIA, M. 1996: 63)

todas as patentes. $\mathrm{Na}$ Capitania de Goiás, ${ }^{41}$ numa escala menor, a situação se assemelhou à de Minas Gerais. Os artesãos parecem ter sido os maiores autores desses "riscos". Entretanto, não se deve desconsiderar a participação dos militares na sua elaboração, pois muitos estiveram na região e trabalharam como mestres, pedreiros e carpinteiros. Dentre eles, o sargento-mor da cavalaria auxiliar, Tomás de Souza, ${ }^{42}$ que levantou a planta da Fortaleza de Nossa Senhora da Conceição, em Mato Grosso.

Em Goiás, esses desenhos correspondiam basicamente a plantas e elevaçõos ou apenas plantas, que definiam as dimensões dos principais ambientes, como a nave, altares, consistórios etc, e as marcaçóes gerais dos elementos verticais. Para as capelas de pequenas dimensóes, os construtores praticamente podiam dispensar esses desenhos, providenciando as traças apenas para frontispícios e ornamentação interna: arcos, altares, púlpitos e pinturas.

41 "Em alguns casos como, por exemplo, a Irmandade de S. Sacramento de Meia Ponte possuía muitos de seus artrffices (carpinteiros, marceneiros, telheiros etc.) dentro de seus próprios quadros.

A mesa da Confraria escolhia os artffices mais capazes para a realizaçăo dos projetos, evidentemente de acordo com suas posses, discutia-os, apresentava novos riscos, dependendo de sua cultura ou influência pela lembrannça da terra distante". MAGALHĀES, Carlos Fernando Filgueiras de. "Confrarias religiosas como expressäo artística nos séculos XVIII e XIX nas minas dos Goyazes."
In: Revista do Instituo Historico e Geográfico de Goiás, n. 1, v. 14, 1998. p.21-35.

42 Tomás de Souza, 1759 - Sargento-mor de cavalaria auxiliar da Capitania de Goías. Esteve em Mato Grosso em 1767, quando levantou a planta da Fortaleza de N. S. da conceiçăo. MOURA, Carlos Francisco. "Apontamentos para Dicionário de artistas

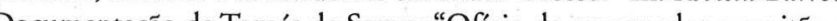
estado [da Marinha e Ultramar], Francisco Xavier de Mendonça Furtado, sobre pedido do governador de Maco Grosso solicitando o envio de um oficial que tenha ciênncia militar, para defesa contra os castelhanos e informando ter enviado à Capitania de Mato Grosso o oficial Tomás de Sousa, o que freqüentou a Academia Militar do Rio de Janeiro". Arquivo
$\mathrm{O}$ único plano completo ${ }^{43}$ para edifício religioso em Vila Boa, nos padróes de uma concepção eminentemente portuguesa, foi o da Matriz de Santana, como indica a provisăo de 1745, "enviada pello Governador da Capitania, com planta e risco para a Igreja Matriz della; já que se achava quasi acabada, e coberta, pella primeira planta e risco que esta Camara poz na Real prezença de Vossa Magestade, menos a primeira, simalha do frontíspicio; e desta primeira simalha, o ultimo remate, e torres, que pretendemos que continue na forma que $V$. Magestade mandar, ainda que nos conduz a mayor despezas, pela pedraria, pois a de porta, janella, pillares do frontispicio, arco, presbitério e coxias, tem sido exorbitante(...)" 44

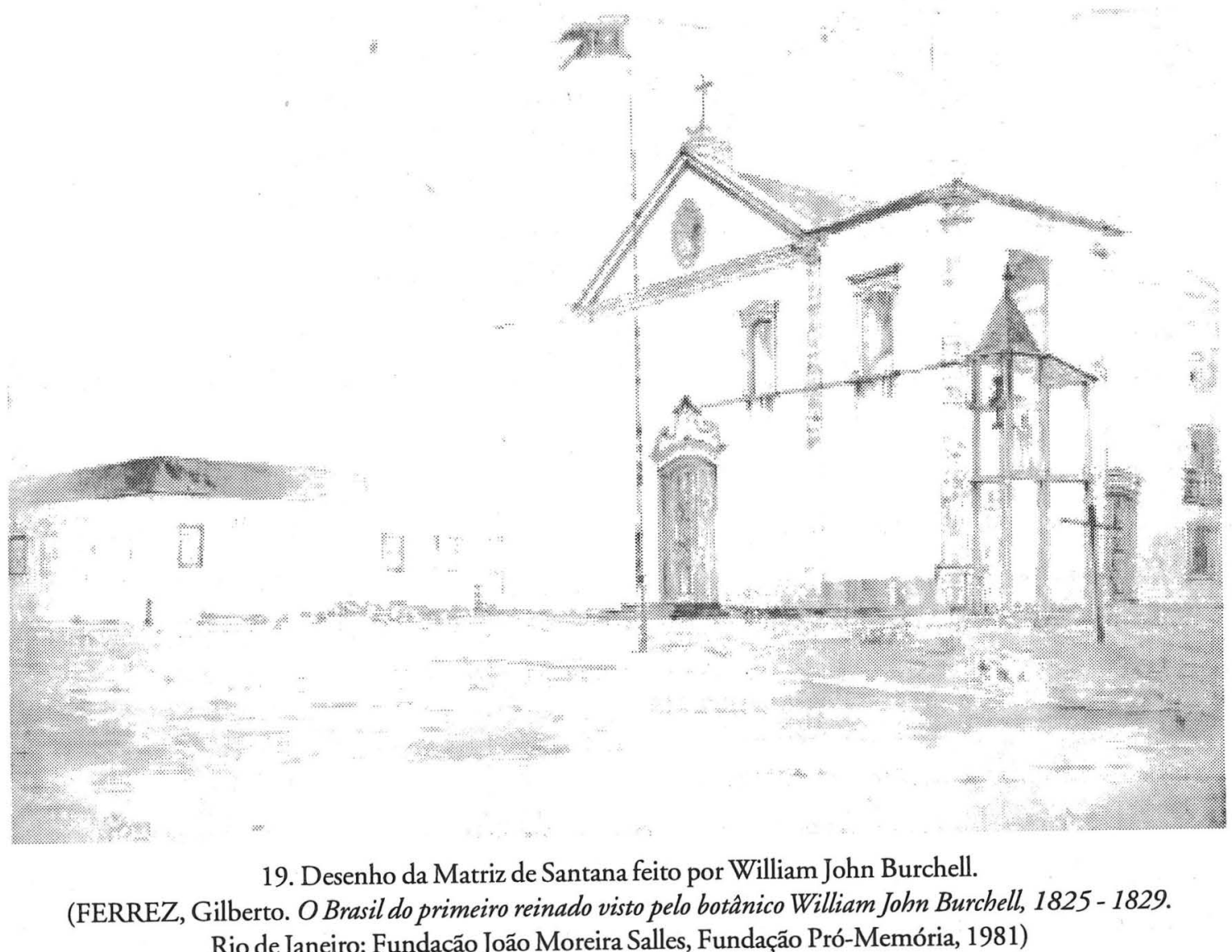

43 Em documento de 1833 encontram-se as dimensōes da Matriz de Santana: “ Exame a que se procedeu, com a assistência do Ex. Co Conselho sobr
dimensōes.

Achou-se ter caído o Arco cruzeiro, e com sua queda arrastado parte das paredes da Capela Mor, e do Corpo da Igreja e com ellas o telhado ameaçado próxima rúna total desse edifício, e até perigo público, havendo contudo muitas (...) dignas de poder servir para reedificaçăo e que convém aproveitar antes que sobre ellas caia alguma parede, que as torne inúteis, e medindo-se interiormente, achou-se ter da porta principal ao Arco Cruzeiro cento e vinte palmos; do Arco Cruzeiro até o Altar Mor setenta; de largura o Corpo da Igreja cincoenta e seis, e a Capela - Mor trinta e oito; as paredes lateraes de altura cincoenta e sete, e de grossura oito; largura da frente inclusive as torres cento e trítz 2 e hril de 1833". Arquivo Frei Simäo Dorvi. Sobre a ruina da Matriz de Santana. Documento avulso. Cidade de Goiás.

${ }_{4}$ da Arquivo Frei Simắn. Documento avulso de 1745. Cidade de Goiás. 
Esse novo plano visava a oferecer as informaçôes necessárias para a execução da Matriz, com desenhos que, provavelmente, deveriam compreender plantas, vistas ou prospectos, pretendendo garantir a unidade do edifício. Isso pode ser visto na ênfase com que os erectores chamaram a atenção para a cimalha, o arremate, os pilares, $\mathrm{o}$ arco e o presbitério. Com todas essas indicações e o esmero na execução dos ornatos, ${ }^{45}$ buscava-se garantir maior unidade de concepção e técnica construtiva da Matriz em relação às demais igrejas de Vila Boa.

De acordo com o relato de Cunha Mattos, a construção dessa igreja parece ter atendido às exigências básicas para um edifício desse porte:

a matriz ou catedral da prelazia dedicada a Santa Ana é mui espaçosa e tem 9 altares. $\mathrm{O}$ altar-mor é obra soberba. Tem colunas de madeira de grandeza notável, e acha-se mui bem dourada. Os altares colaterais são mui asseados, e nenhum deles se dá em capela funda. Nesta igreja e em todas as outras da prelazia. ${ }^{46}$

No que diz respeito às demais igrejas de Vila Boa, não se tem notícia de traças para a sua execução, o que não significa dizer que não havia orientações gerais sobre as obras e desenhos para os detalhes mais sofisticados, que, comumente, não faziam parte do repertório técnico construtivo.

Como orientaçốes gerais, contaram com os seus respectivos autos de fundação, que estabeleciam locaçōes e dimensōes de naves, altares e, quando previstos, adros. $\mathrm{O}$ uso das traças, por certo, limitou-se às concepçóes mais complexas, como as das naves octogonais e as ornamentaçốes internas $\mathrm{e}$ externas. O "desenho" agia, em grande parte, como um recurso parcial e pontual para algumas soluçóes, tornando-se um dos responsáveis pela descontinuidade estilística e composicional das capelas.

Dentre as igrejas que se utilizaram de traças, destaca-se a de Nossa Senhora da Boa Morte, por suas qualidades formais. Nela, os "desenhos" e as distintas participaçóes de profissionais exerceram um papel importante, particularmente em dois momentos de sua construção: no primeiro, a traça garantiu a conformação geral do arcabouço do edifício em plano octogonal, que implicou a adoção de outras soluçốes, como as inclinaçóes dos retábulos próximos ao arco- cruzeiro e a sucessão dos vários arcos que apóiam o coro e ajudam a formar o octógono, garantindo unidade; no segundo momento, as novas soluçóes para o frontispício, que interromperam a unidade do espaço interno. Com a percepção dessa lógica construtiva, ficam claras as diferentes etapas de trabalho realizadas em Boa Morte, responsáveis pelas características ambíguas do edifício. A igreja, em seu interior, apresenta-se com extrema sobriedade e simplicidade, reveladas, por exemplo, nos arcos de sustentaçáo do coro; no frontispício, no entanto, encontram-se formas mais dinâmicas, com um frontão aberto apoiado em uma cimalha que se integra às quatro colunas que ritmam a fachada e marcam, finalmente, o contraste entre as relaçóes internas e externas.

Nossa Senhora do Carmo é também outro edifício que, provavelmente, utilizou os recursos das traças, na medida em que apresenta um curioso plano octogonal de características bem mais complexas

45 "huma esmolla, para se aperfeiçoar, e ornar a capella-mor_....)" Arquivo Frei Simäo Dorvi. Auto de Arbitragem da matriz de

${ }^{46}$ MATTOS, Raymundo José da Cunha. Chorographia historica da provincia de Goyaz. Goiânia: Líder. p. 97 que as da Igreja da Boa Morte. Nessa capela, a unidade construtiva do espaço interno é percebida po que as da Igreja da Boa Morte. Nessa capela, a unidade indicativos que a própria arquitetura oferece. A forma octogonal da nave foi parcialmente definida por paredes de taipa e, na estrutura de sustentaçáo do coro, por arcos de madeira trilobulados.

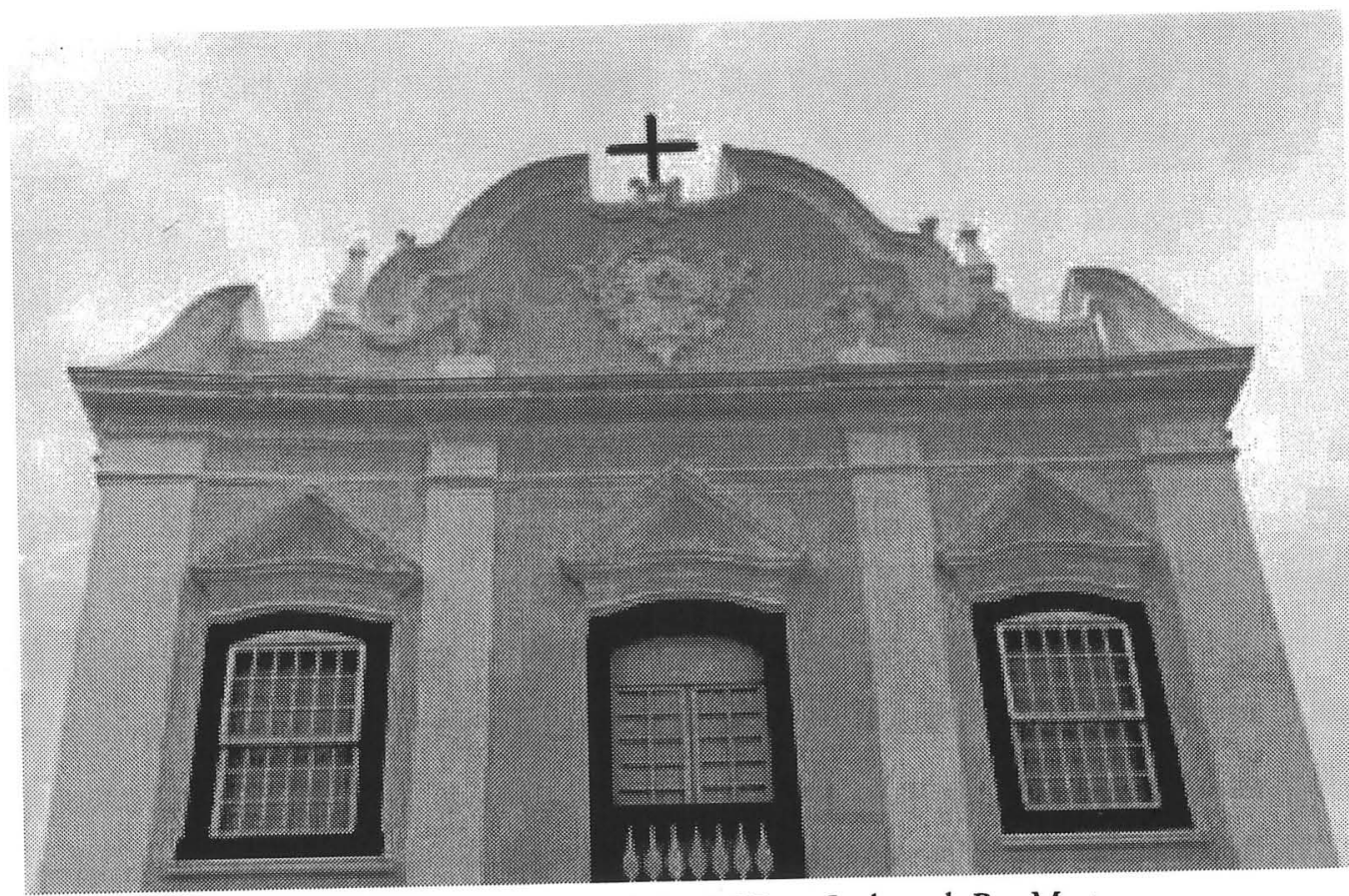

20. Detalhe do frontispício da Igreja Nossa Senhora da Boa Morte. (Foto de Deusa Maria Rodrigues Boaventura)

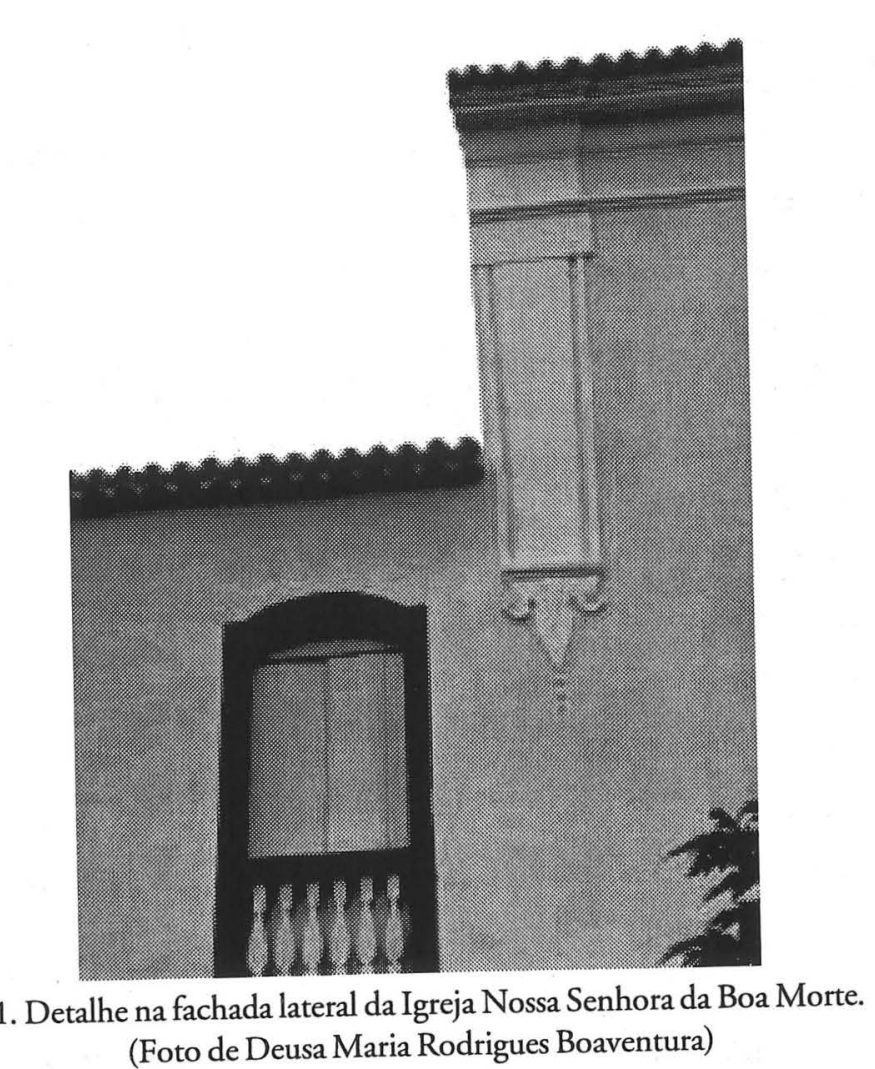

21. Detalhe na fachada lateral da Igreja Nossa Senhora da Boa Morte. 


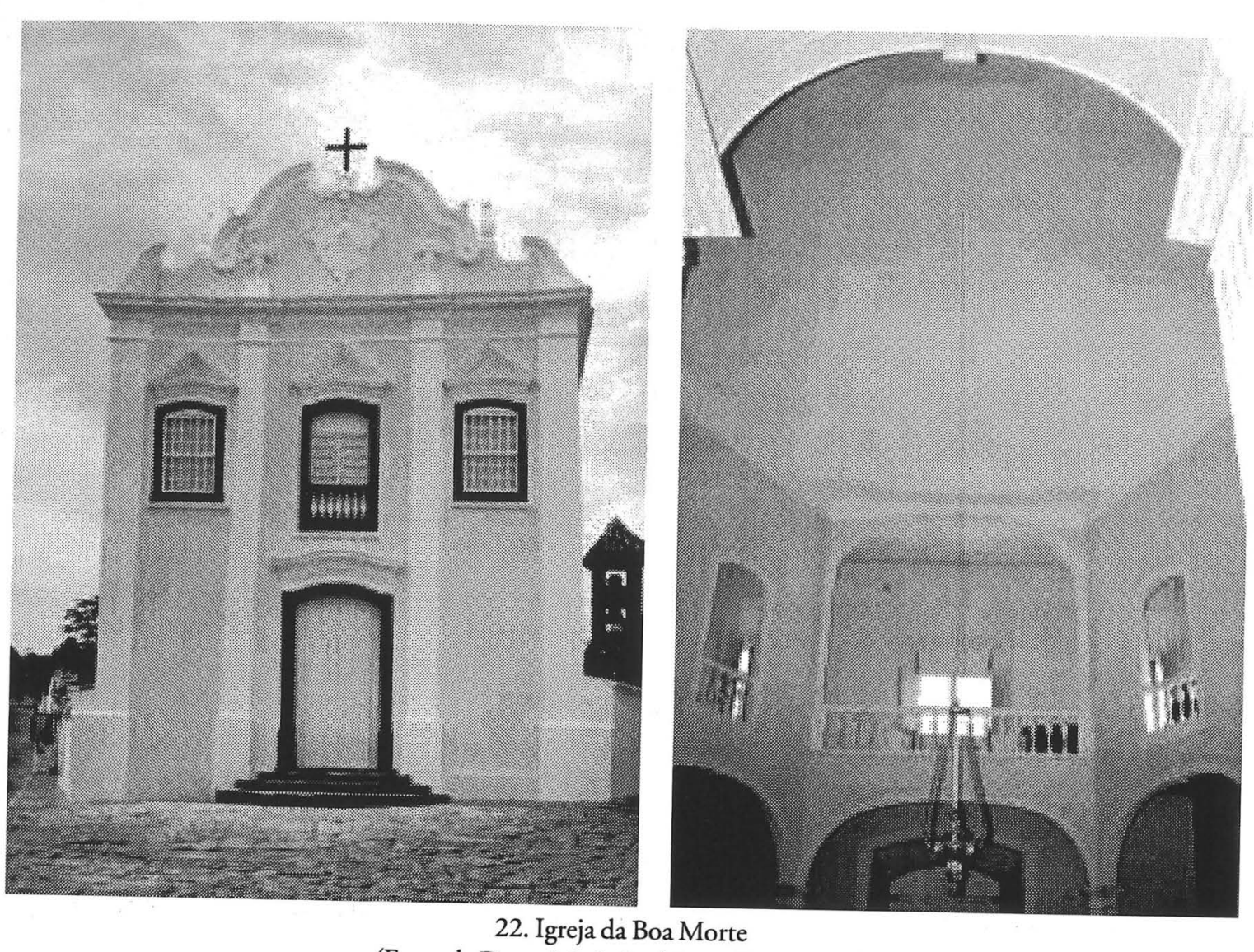

(Fotos de Deusa Maria Rodrigues Boaventura)

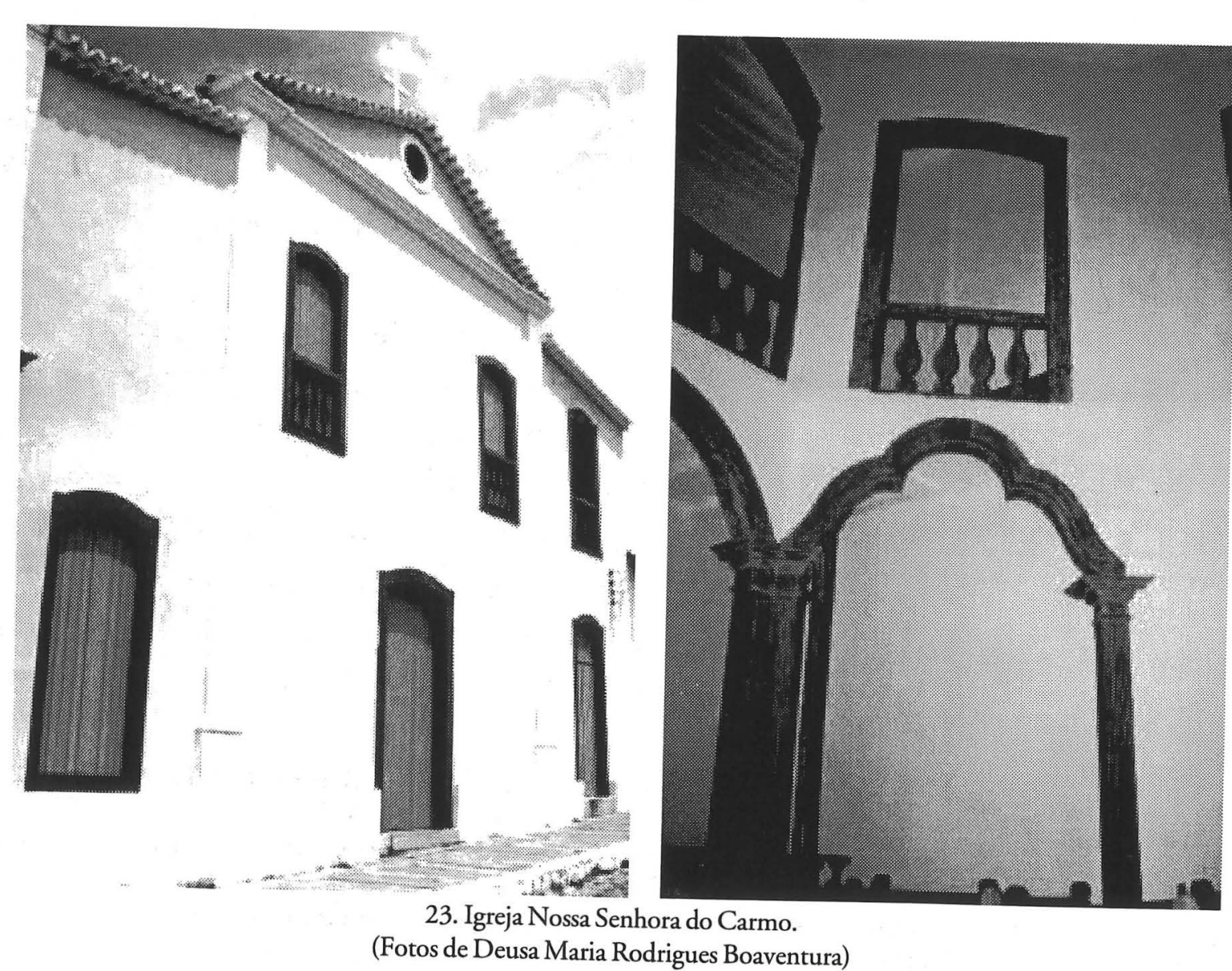

(Fotos de Deusa Maria Rodrigues Boaventura)
No entanto, não obstante esses elementos articulados, essa unidade náo garantiu a qualidade construtiva do edifício, altamente comprometido por uma série de irregularidades de natureza técnica, quando se anexaram salas destinadas ao consistório e sacristia à nave. Em contrapartida, sinalizando novamente para a participação de diferentes profissionais, encontram-se nela peças bem elaboradas, como o púlpito e os arcos de sustentaçáo do coro.

Com tais características, e a despeito dos vários profissionais que participaram de sua construção e marcaram algumas descontinuidades em relaçáo à qualidade de algumas peças, essa igreja manteve maior unidade construtiva que sua congênere Boa Morte, pois não se vêem posteriores intervenções para a execução de ornamentos, limitando-se apenas aos traços gerais de um tradicional ediffcio para capela revestido de muita simplicidade.

Nossa Senhora da Abadia é, dentre todas as capelas vilaboenses, a de melhor qualidade construtiva, especialmente em alguns de seus aspectos internos: um arco-cruzeiro, um púlpito, um teto e um retábulo para a capela-mor de considerável beleza. Diferentemente de Boa Morte, cujo espaço interno é simples, Nossa Senhora da Abadia apresenta formas mais dinâmicas, sinalizando para grandes descontinuidades formais.

Externamente, a capela é formada por três volumes retangulares que correspondem à nave, anexos e torre. $\mathrm{O}$ primeiro e principal deles segue a mesma modenatura das demais igrejas, porém com poucos e discretos detalhes que arrematam janelas e portada e com um frontão recortado que se apóia numa cimalha bastante simples.

No seu interior, o volume que corresponde à nave mantém a mesma singeleza do exterior, com alguns elementos posteriormente concluídos e mais elaborados, como o púlpito, o parapeito ${ }^{47}$ que separa a capela-mor da nave e $\mathrm{o}$ arco-cruzeiro. Esse último revela algumas intençóes ilusionísticas na sua disposiçáo em ângulo, proporcionando um efeito incomum às demais igrejas. Essa idéia de efeito perspéctico comparece também na pintura do forro da nave, ${ }^{48}$ com qualidades plásticas que não se encontram nos outros edifício de Vila Boa de Goiás.

Essas diferenças entre os elementos interiores e o aspecto interno e externo evidenciam o descompasso artístico existente na configuraçáo geral da capela, que conjuga a simplicidade arquitetônica do arcabouço do edifício com maior elaboraçăo de determinadas peças, remetendo ao uso de traças $\mathrm{e}$ confirmando o tradicional esquema que se desenvolveu em Vila Boa.

Já São Francisco de Paula ${ }^{49}$ e Santa Bárbara são exemplares cuja qualidade construtiva e simplificação formal não apontam para o uso da traça. Parecem ter contado apenas com as indicações previstas nos seus respectivos autos de fundação, assegurando as tradicionais formas de organização dos espaços litúrgicos, com naves, altares-mores, coros e etc, nas mesmas articulaçóes.

47 No livro $A$ hispanidade em Säo Paulo, Aracy Amaral mostra esse mesmo detalhe em obras de São Paulo, afirmando ser de influência espanhola. AMARAL, Aracy. A hispanidade em Săo Paulo. São Paulo: Nobel, 1981. p. 27.

${ }^{48}$ Essa pintura apresenta como tema central Nossa Senhora da Abadia circundada por outras figuras celestes, entre tronos,

49 N. S. da Abadia á a única igreja a possuir pintura no forro da capela-mor. Sua pintura evoca trechos da vida de S. Francisco de Paula executados no séc. XIX por André Antônio da Conceiç̄ón 


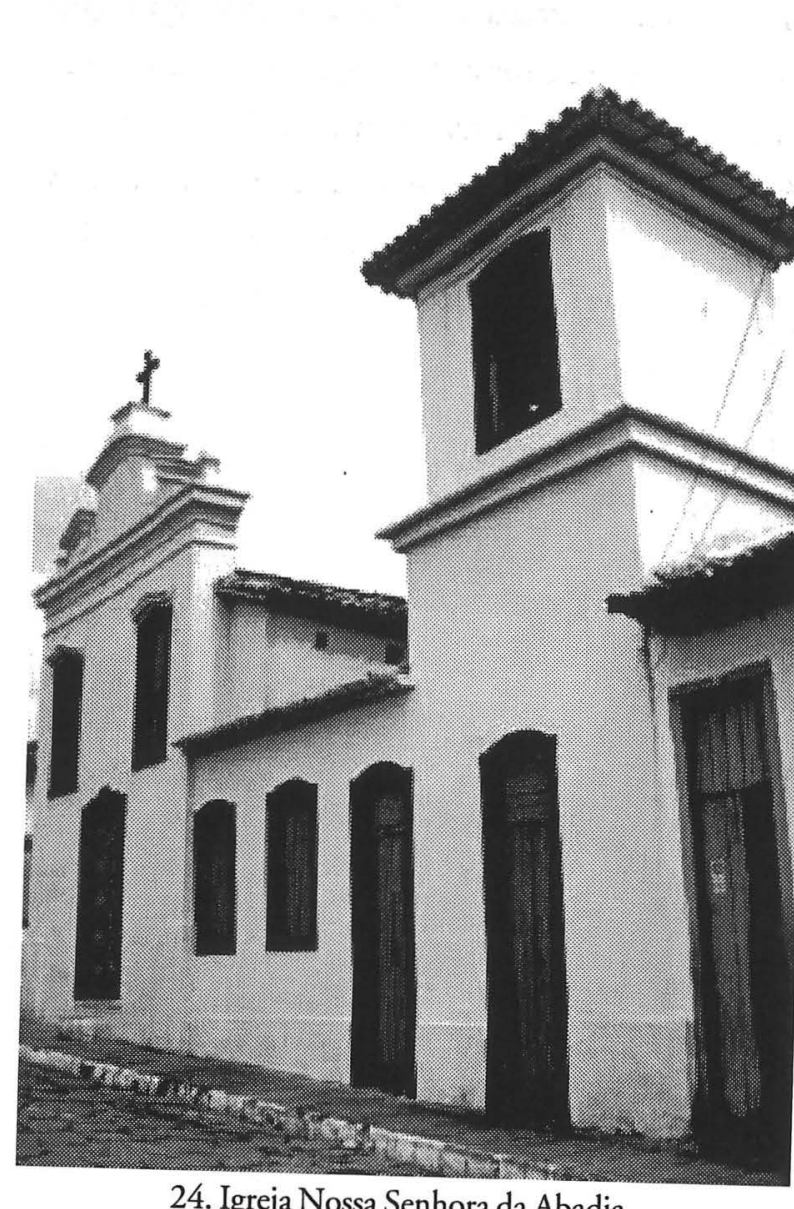

24. Igreja Nossa Senhora da Abadi. (Foto de Deusa Maria Rodrigues Boaventura)

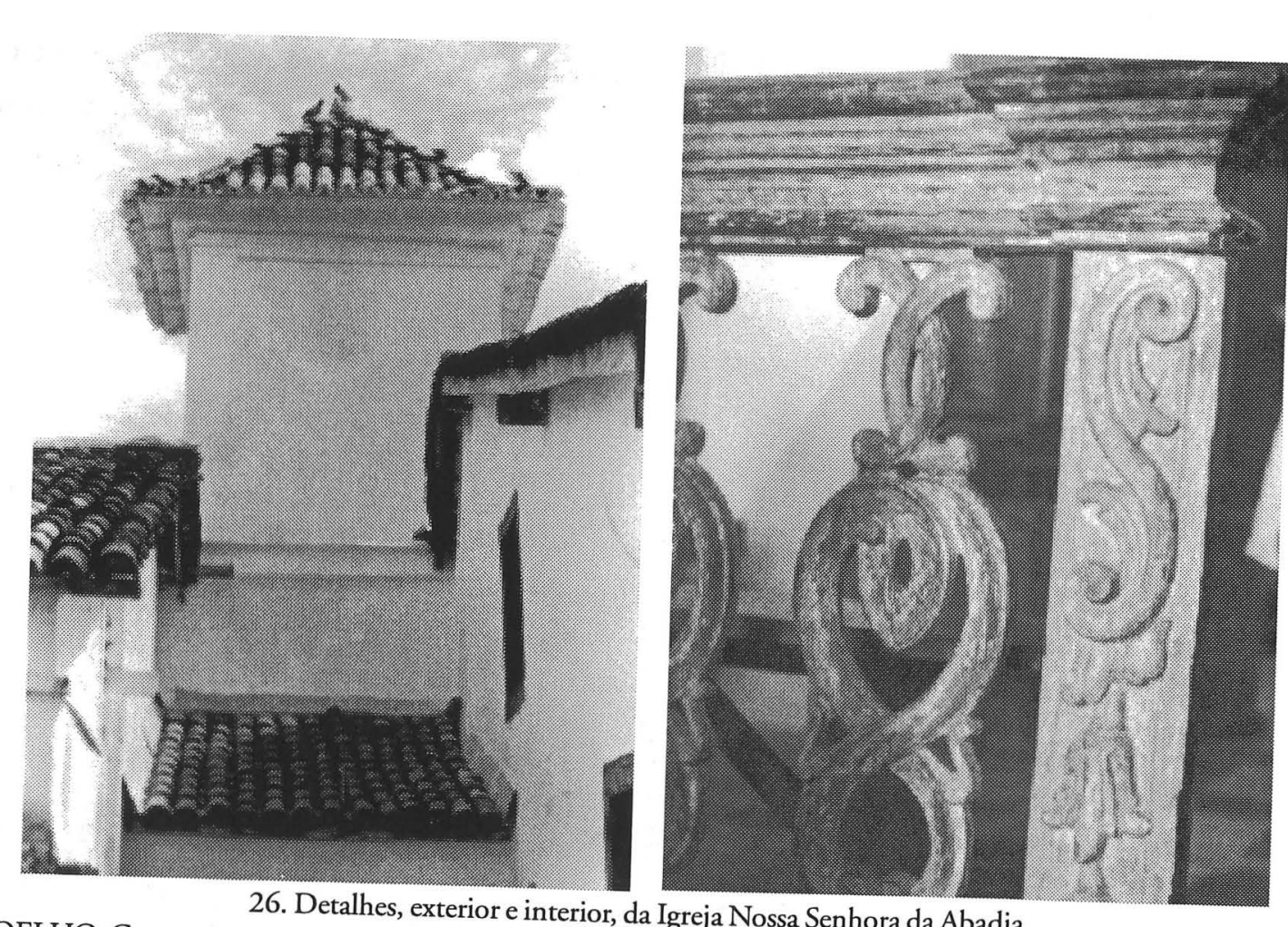

(COELHO, Gustavo Neiva. Detalhes, exterior e interior, da Igreja Nossa Senhora da Abadia.

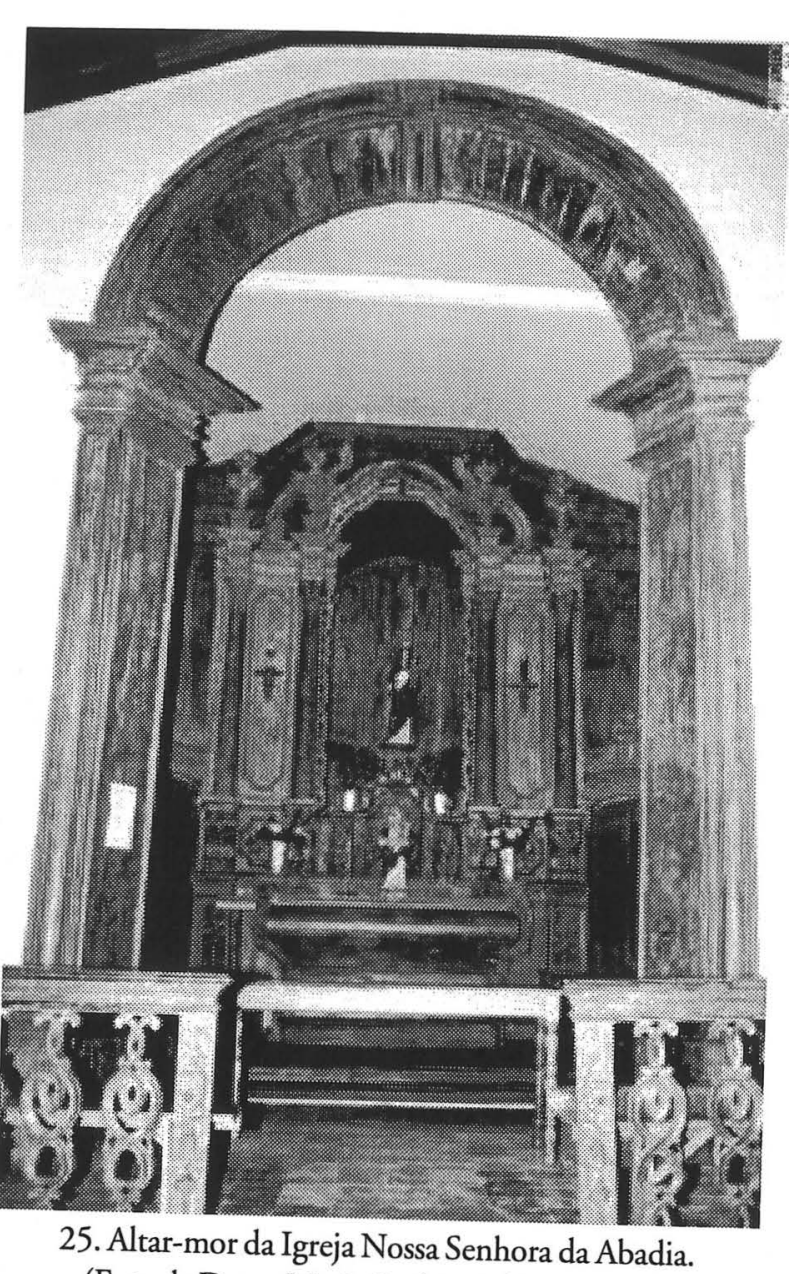

25. Altar-mor da Igreja Nossa Senhora da Abadia.

vava. Guia dos bens imóveis tombados em Goiás. Goiânia: Fundaçăo Cultural Pedro Ludovico, 1999)
Com o recurso das marcações dos autos, São Francisco de Paula assumiu uma configuração espacial desenvolvida a partir de um retângulo central para a nave e dois outros para seus corredores laterais. Sua fachada, correspondente ao volume central, segue o tradicional esquema em 'V', composto por única porta e duas janelas acima. Caracteriza-se pela simplicidade e economia de meio estéticos, sem contrastes formais como os de suas congêneres. Internamente, mantém o mesmo diálogo com as formas externas simples e austeras.

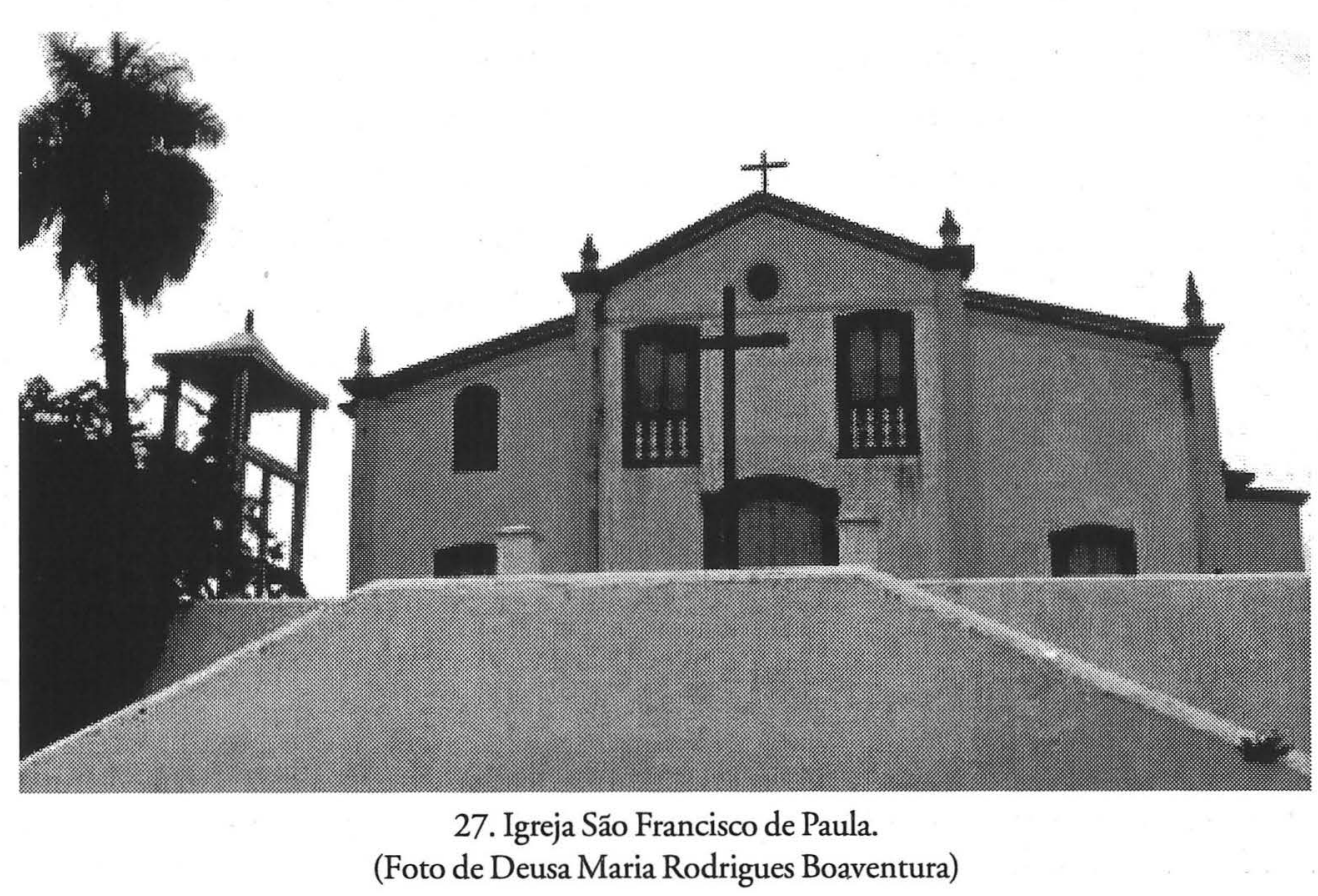

Santa Bárbara comporta também a composição em diagonal em seu frontispício. No entanno sua planta, reside uma particularidade: com reduzidas proporçóes e forma retangular, a capelamor está incrustada num volume maior que, como uma caixa, engloba e fecha todo o conjunto da

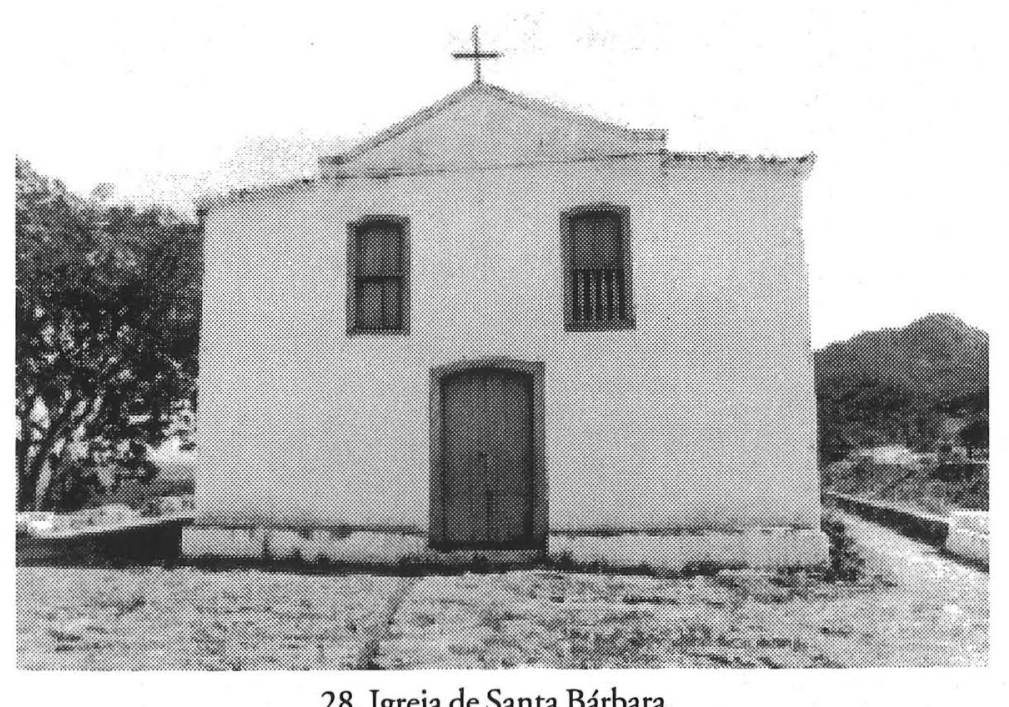

(COELHO, Gustavo Neiva Guia dus hems imudis 
construçáo, criando linhas simples e sóbrias. O volume da capela-mor funciona como um elemento que separa a nave da sacristia, com a ligaçáo entre as duas feita por corredores laterais. Seu espaço arquitetônico, de decoração singela, não assume muitos contrastes. Porém, do ponto de vista técnicoconstrutivo, singulariza-se por ser a única capela contrafortada.

Nesse quadro das igrejas de Vila Boa, reconhecem-se sempre traços de austeridade e sobriedade. No entanto, essas características não permanecem, porque percebe-se que os seus vários construtores, em diferentes momentos, intervieram no seu processo executivo, com inovaçóes que geralmente manifestam defasagens e descontinuidades estilísticas nas ornamentaçóes de fachadas ou de acessórios. Nos arcos e púlpitos, isso se evidencia: na maioria das vezes, apresentam maior apuro formal, com soluções que não só imprescindiram de riscos detalhados, mas também assumiram formas típicas canônicas, levando a indagar sobre a provável circulação de gravuras entre os diferentes profissionais que as construíram.

Essas descontinuidades e defasagens, no entanto, tornam-se menos evidentes em face do respeito a uma organização espacial hierárquica de ordem litúrgica, que orientou articulaçóes similares para todas as igrejas. Naves, capelas e altares vinham sempre trabalhados por uma oucuçós similares seguia e respeitava tais valores, enfatizando os altares, arco-cruzeiros, púlpitos e portadas. A coerência que esses elementos de maior apuro ornamental e interesse mantinham com a ordem hierárquica do espaço litúrgico, persiste como um dos principais responsáveis pelo aspecto da unidade que, náo obstante as descontinuidades estilísticas, lograram essas igrejas.

\section{4 \\ C A P ÍT U L O}

A ARQUITETURA

DAS IGREJAS:

REFERÊNCIAS

TIPOLÓGICAS 
E xaminar os tipos arquitetônicos das igrejas do Brasil colonial ao longo do século XVIII é tarefa complexa, porque, transpostos ou assimilados na colônia, sucederam-se e reproduziram -se com comportamento próximo aos de Portugal, onde já amalgamavam correntes estilísticas autóctones e eruditas, e outras resultantes de sínteses e derivaçóes dessas duas. A identificação das características da arquitetura religiosa de Vila Boa de Goiás, portanto, requer que se considerem, inicialmente, os diferentes tipos e influências estilísticas que por lá chegaram e a maneira como foram reproduzidos. Assim, o estudo das igrejas de nave única e octogonais em Portugal, bem como o desenvolvimento desses modelos em regióes brasileiras que mantiveram um permanente diálogo com Goiás é de suma importância.

A arquitetura portuguesa do século XVII, antes de aceitar as novidades do barroco e assimilar plenamente suas formas profusas, resistiu com tipos arquitetônicos que se inseriram em tradiçóes artísticas, como as maneiristas, as vernaculare ${ }^{1}$ e as do estilo chão, organizando-se com clareza, ordem, proporção e simplicidade a partir de "fontes teoréticas aparentemente contraditórias: um certo classicismo asséptico e um maneirismo internacionalizado" ${ }^{2}$

No Brasil, os tipos portugueses, como os retangulares e centralizados, chegaram e se estenderam até o século XVIII, alcançando Vila Boa de Goiás por tradição já consolidada ou por influência direta da metrópole, como no caso da Matriz de Santana.

Carlos Lemos aponta que a vertente portuguesa mais erudita chegou às terras coloniais especialmente nas regióes de maior importância, como Salvador, no antigo templo inaciano de 1604. Esses exemplares, caracterizados por considerável monumentalidade e alto grau de erudição, demonstram claramente sua ligação com os tratadistas portugueses, podendo ser os elos de uma corrente

1 “Os tempos sebásticos são esteticamente dominados por valores diferentes mas que graça à circunstancia da conjuntura lusitana, convergem para um estilo peculiar e portanto nacional e de tendência vernacular." HORTA CORREIA, José Eduardo. Arquitetura portuguesa: renascimento, maneirismo, estilo chão. Lisboa: Editorial Presença, 1991. p. 43.

ก 2 Op. cit., p. 42. 

estilística que alcançará todo o século XVIII. Entretanto, mesmo entendendo a produçáo do litoral
dentro de duas grandes vertentes, Carlos Lemos diz:

(...) não é fácil precisar se uma obra portuguesa é ou não maneirista quando levantada na vigência daquela transição estilística entre Renascimento e o Barroco, principalmente quando a tal corrente era ainda novidade no reino. Cremos ter havido muitas coincidências formais, principalmente nas construçóes feitas nas colônias, que displicentemente taxamos de maneiristas, mas que esț̃o, nas realidade, à espera de uma denominação apropriada, antes de tudo, por motivos didálos. Tave na expressão 'chă", usada pelos críticos porluguses

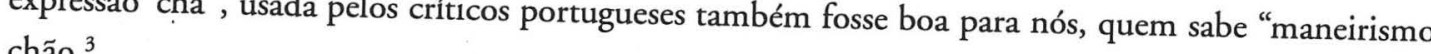

Dessa maneira, para uma investigaçáo das igrejas de Vila Boa de Goiás, deve-se ter em conta os tradicionais tipos de nave única, que se desenvolveram amplamente em Portugal e na Colônia, bem como os octogonais, considerados mais raros no Brasil, mas que, segundo José Fernandes, se espalharam por todo o território lusitano, inclusive em regiōes provinciais. ${ }^{4}$ Esses tipos, especialmente os de nave única, iniciaram sua consolidação no momento em que o estilo chão se impunha em Portugal como corrente artística predominante. Ao lado dele, emparelhavam-se também outras tendências estilísticas mais eruditas, configurando um panorama artístico português de grande diversidade tipológica.

\subsection{A ARQUITETURA PORTUGUESA E VILA BOA}

Dois foram os momentos em que se ergueram os edifícios religiosos de Vila Boa de Goiás correspondentes a períodos distintos do século XVIII: o primeiro, anterior à década de 50, foi marcado pelas construçóes da antiga Matriz de Santana e da Igreja Nossa Senhora do Rosário - no contexto da história da arte portuguesa, relaciona-se ao período mais relevante do barroco português; contexto da metade desse século, com a construção das caper Carmo, Nossa Senhora da Boa Morte, Santa Brán Cmorte, Santa Bárbara e Nossa Senhora da Abadia, erguidas no período em que, na metrópole, já se desenvolviam os estilos rococó e pombalino. No entanto, associado a "ssas tendências, permaneceu como pano de fundo o tradicional estilo chão, que se firmou como "corrente dominante (virada da primeira para a segunda metade do século XVI) da arquitetura portuguesa, correspondendo de certo modo a uma ansiedade idiossincrática nacional, mas afirmandose numa conjuntura favorável da cultura nacional, de predomínio da arquitetura militar e de contra reformismo religioso". 5

O estilo chäo surgiu paralelamente aos exemplares renascentistas, caracterizando-se por uma arquitetura sóbria e fundamentalmente pragmática, resultante de inúmeras experiências de colonização africana, com contribuiçôes de militares construtores preocupados com edificaçóes de ordem prática, tanto no reino como nas colônias.

3 LEMOS, Carlos. "No Brasil, a coexistência do maneirismo e do barroco até o advento do neoclássico histórico". In: Afonso Avila (org.) Barroco - teoria e análise. Belo Horizonte: Perspectiva, 1997. p. 234

4 Para maiores informaç̄os sobre os tipos provinciais, ler PEREIRA, José Fernandes. Arquitectura barroca em Portugal. Lisboa:
Biblioteca Breve, 1992. p. 149 .

HORTA CORREIA, José Eduardo. Op. cit., p. 42.
Horta Correia adverte que a prolongada resistência do estilo chão até o final do século XVIII possibilitou que ele incorporasse diferentes influências, culminadas num fenômeno heterogêneo complexo que envolveu vertentes eruditas, autóctones e soluçóes derivadas de "modelos nacional e romano". ${ }^{6}$ Reconhece também que, além dessa vertente mais pragmática, que incorporou elementos estruturais de escolas militares, formou-se uma outra, assimilando tendências italianas, espanholas e flamengas que permaneceram até a Restauração.

Simultaneamente ao estilo chão, durante o reinado de Felipe II desenvolveu-se o Maneirismo, que, "automaticamente, se afirmou conseguindo escapar à tendência dominante na arquitetura tradicional". Foi aceito em regióes de expansão ultramarina e de Portugal até o século XVII, a exemplo de Coimbra. Caracterizava-se pela absorção de influências flamengas e, através de Juan Herrera, o conhecimento de Vignola e Palladio, assimilado nas leituras de Serlio.

Foi no contexto dessas várias correntes artísticas, reconhecidas por uma arquitetura mais sóbria e de caráter utilitário, que José Fernandes localizou as origens do barroco lusitano, através de opçóes por formas mais flexíveis que, gradativamente, substituíram as mais sóbrias, rumo a uma maior liberdade, e reconduziram os artistas portugueses às plantas centralizadas, utilizadas no Renascimento. Com essas inovaçóes, estabeleceu-se o confronto de uma linguagem artística mais dinâmica com as vertentes mais tradicionais e maneiristas.

As primeiras manifestaçóes do barroco podem ser percebidas, portanto, através de sutis renovaçoes espaciais, antes mesmo de 1640 , quando a arquitetura se tornou completamente coberta por azulejos e talhas douradas, com acentuada valorização de seus espaços. Até 1670, essas inovaçóes se caracterizavam apenas por uma maior dinamização espacial, alcançada através de cromatismos e reflexos luminosos empregados em peças. Somente após esse momento, surgiram, no território lusitano, edifícios mais dinâmicos, como as pequenas capelas e ermidas que adotaram planos hexagonais e octogonais.

No Brasil, boa parte das primeiras igrejas está associada, segundo John Bury, ${ }^{8}$ a uma produçăo maneirista desenvolvida pelos jesuítas até 1759. A partir dessa data, surgem os exemplares com formas barrocas apenas em talhas e retábulos. Posteriormente, seguem os tipos mais dinâmicos, de tendência erudita. Ressalva, no entanto, que a arquitetura mineira da primeira metade do século XVIII aproxima-se da vertente mais autóctone de Portugal, podendo-se sugerir o mesmo para o caso de Goiás.

\section{Idem, p. 15}

"O arquiteto maneirista sofria um estrito controle da autoridade. Estava sujeito na organizaçăo de seu projeto, à superviša durante sua execuçăo e ao questionamento subsequente a respeito de qualquer idiossincrasia nos detalhes. A essa disciplina se podem atribuir as tendências acadêmicas da ultima fase do Maneirismo. A Acta Ecclesiae de Carlos Borromeu estabelecia uma série de regras e proibiçóes para o projeto de igrejas (...). A planta baixa circular foi condenada por Săo Carlos como pagăa e cruz latina restabelecida como verdadeiro simbolo cristäo." BURY, John. A arquitetura e a arte no Brassi colonial. ORG. Myriam de Andrade de Oliveira. Săo Paulo Nobel, 1991 p. 54 .

ล⿵ 8 BURY, Jonh. Op. cit., p. 44, 47. 


\subsection{IGREJAS BASILICAIS E DE NAVE ÚNICA: A DEFINIÇÃO DOS TIPOS}

A antiga Matriz de Santana de Vila Boa de Goiás, iniciada por um plano paulista e concluída por um português, aponta soluçóes que remetem não só a uma tradicional arquitetura colonial, com também a um modelo português cujas origens encontram-se nas práticas militares, "expressando com êxito popular uma corrente autóctone que, a partir de determinada altura, começa a ridicularizar os "italianizados". É esta a corrente triunfante do "estilo cháo"através das igrejas- saláo, primeiro, das novas soluçóes espaciais de origem nacional experimentadas pela primeira vez em São Roque, e no Espírito Santo, depois."

Foi com as igrejas-salôes que se iniciou, na Europa, um maior interesse pelos espaços unificados, que evitavam soluçóes complexas. Organizavam-se basicamente por paredes em forma de painéis que limitavam amplos espaços encimados por coberturas mais simplificadas. Em Portugal, essa tipologia foi bastante utilizada e só superada pela de nave única, consolidadas sobretudo a partir das orientaçốes da Acta Ecclesiae de Carlos Borromeu, ${ }^{10}$ no período da Contra- Reforma.

São Roque é o primeiro caso conhecido de igreja de nave única, embora tenha oscilado entre o modelo da "hallenkirchen", ${ }_{11}^{11}$ ou igreja-salăo. Assinala a preferência e a mudança do gosto português a favor de uma arquitetura "nacional", ${ }^{12}$ de plano unificado, visando a atender ao maior número de fiéis. Apresenta-se, geralmente, sem transepto, com capelas colaterais intercomunicantes sobrepostas por tribunas e com dois púlpitos visíveis, que se fixam em paredes simetricamente opostas - tipo que se espalhará por várias partes do mundo, não sendo apenas um privilégio dos jesuítas. ${ }^{13}$

A concepçáo original de Espírito Santo de Évora reflete essa nova tendência arquitetônica. Sua planta, que se desenvolveu a partir de uma ampla sala central coroada por uma abóbada de berço, distingue-se da de São Roque e São Francisco pelas capelas laterais intercomunicantes. Mostra uma notável tendência à concentraçăo, espaço retangular e eliminaçáo do transepto.

Por causa da crescente aceitação e popularizaçáo desses planos unificados, acontecidas não só por suas facilidades construtivas, como também pela possibilidade de acolher um grande número de fiéis, atendendo, assim, satisfatoriamente, às exigências programáticas das companhias religiosas, eles alcançaram as colônias portuguesas, multiplicando-se de forma considerável.

HORTA CORREIA, José Eduardo. Op. cit., p. 52

10 "Carlos Borromeu, em sua obra Instructionum Fabricae ecclesiasticae Libri duo - que data de 1572 - aplicou as disposiçōes do

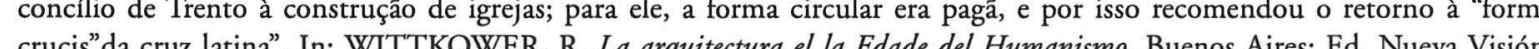
crucis' da cruu

"A igreja salăo, muitas vezes chamada hallenkirchen, segundo os exemplos germânicos medievais, é apenas um caso especial de uma estrutura mais generalizada, cujo aspecto é o de uma igreja de pilares com abóbadas à mesma altura, sobre um esquema modular limitado por luminosas paredes que requerem pequenos contrafortes interiores ou exteriores e que possuem janela apenas nos muros exteriores. Assim esta soluçăo difere das estruturas basilicais, pois estas possuem janelas rasgadas entre os niveis diferentes das coberturas da nave principal e das naves laterais." KUBLER, George. A arquitetura portuguesa chä. Entre especiarias e os diamer

12 Horta Correia, Mário Chicó, Germain Bazin, Pais da Silva e Paulo Santos reivindicam a origem nacional desses planos unificados, conforme especifica Horta Correia. Op. cit., p. 52 .

3 Idem. p. 53.

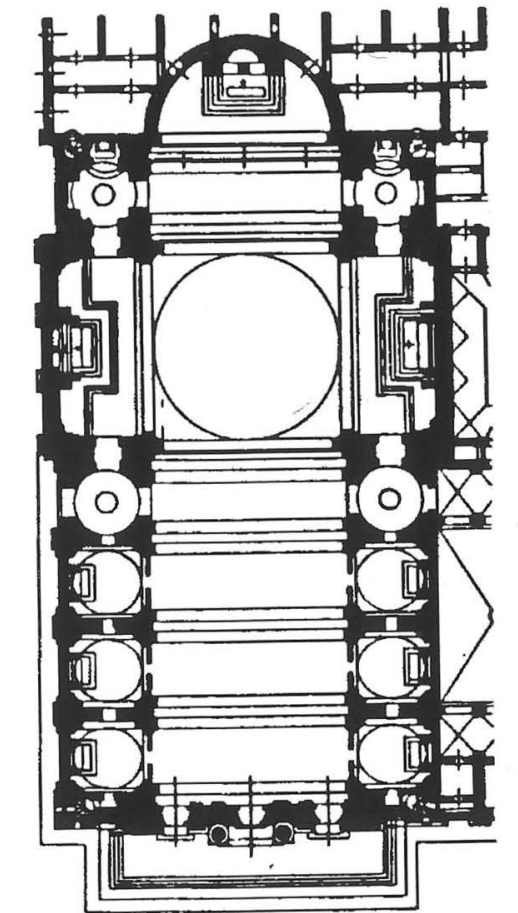

Gesù, Roma.

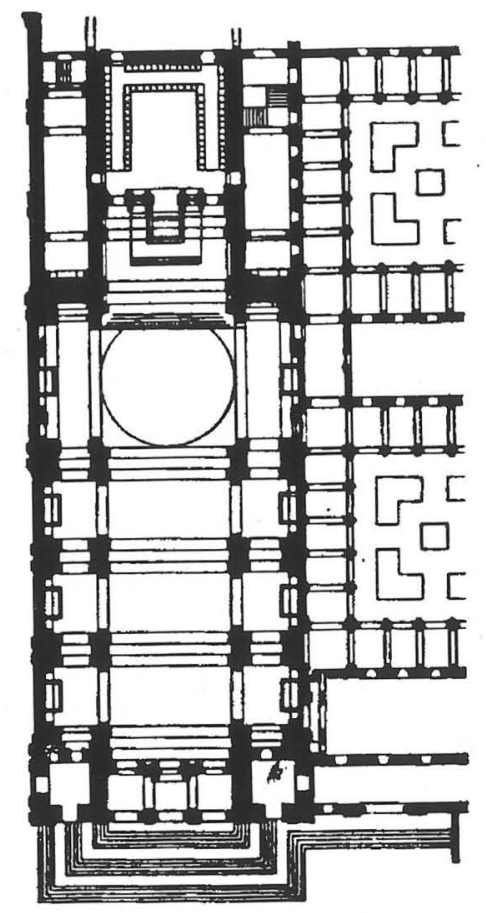

São Vicente de Fora, Lisboa.

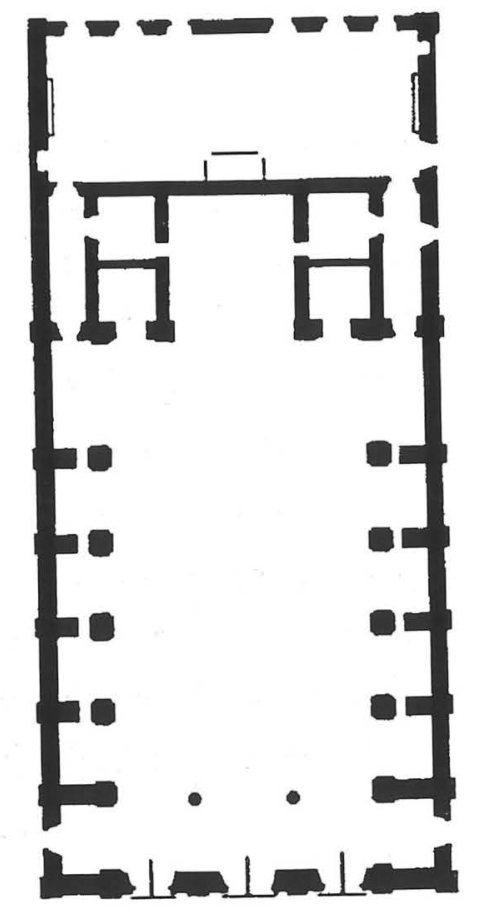

Catedral de Salvador, Bahia

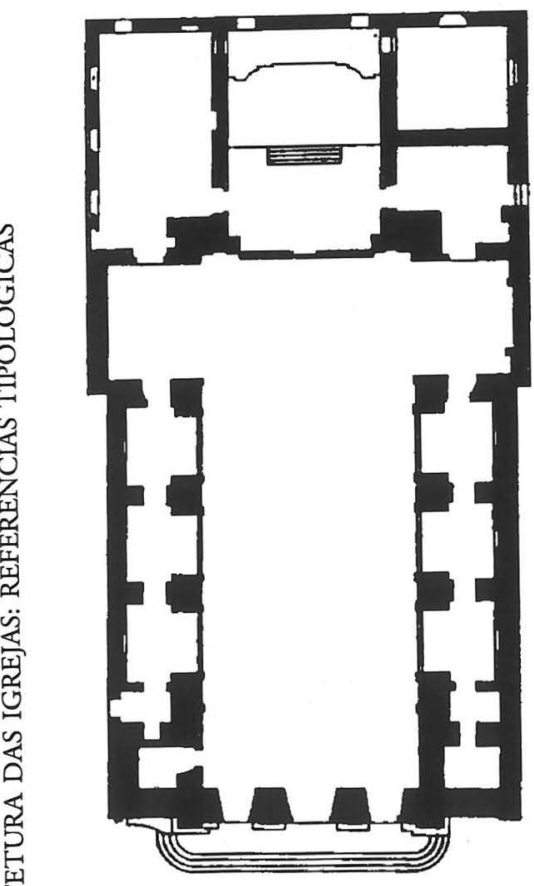

Santo Alexandre, Belém do Pará

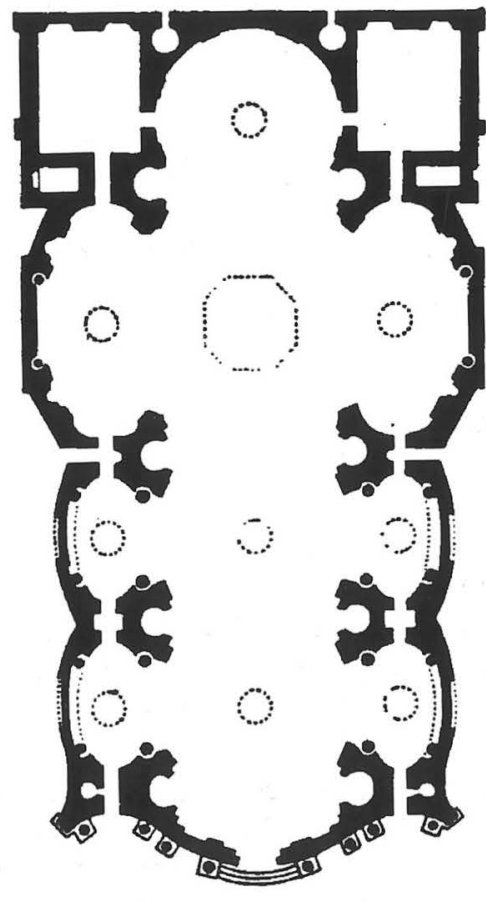

Divina Providência, Lisboa.

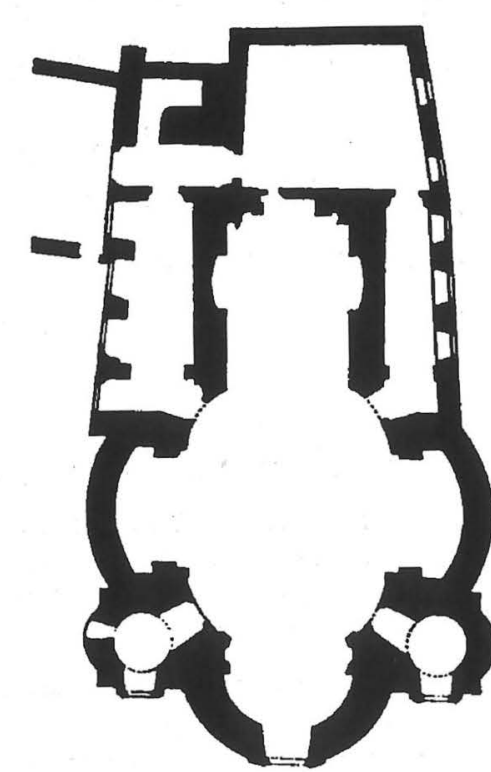

São Pedro dos Clérigos, Rio de Janeiro.
2 Planos retangulares e elípticos de igrejas portuguesas e brasileiras. BURY, Jonh. A arquitetura e a arte no Brasil colonial. São Paulo: Nobel, 1991) 
No Brasil, a tipologia de nave única com capelas laterais se tornará mais comum a partir de meados do século XVI, durante o XVII e, em menor escala, no século XVIII. Lúcio Costa, em $A$ arquitetura dos jesuitas no Brasil, ${ }^{14}$ entende que essas igrejas enquadram-se em quatro tipos básicos principais: as primeiras, mais simplificadas, formalmente compactas, contam apenas com capela-mo e nave constituídas por um único corpo de construção, separadas por um arco-cruzeiro. São consideradas as mais antigas e têm, como melhor exemplo, a capela de Santo Antônio; as segundas são as que se apresentam com três altares e capela-mor de menor dimensão, separada da nave, diferenciando-se daquelas do primeiro grupo, que se desenham com a mesma largura da nave. Esse modelo de composição clara e simplificada foi o que mais se desenvolveu em Minas Gerais; as terceiras associam os tipo mais simples e os planos mais elaborados das igrejas do século XVII. Mantêm ainda os três altare habituais do modelo anterior, acrescentando, nos colaterais, pequenas capelas de maior ou meno profundidade, a exemplo da igreja de Olinda, cujas capelas formam conjunto com a capela-mor; o quarto tipo, o das igrejas maiores seiscentistas, foi influenciado pelo padrão da Igreja Gesù de Roma Tem como representantes as igrejas do Colégio de Salvador, a de São Paulo do Piratininga e de Belém do Pará, que se diferenciam do grupo anterior pelos numerosos altares dispostos em capelas laterais, as próximas ao altar-mor geralmente mais largas e mais altas e, às vezes, mais profundas.

Para Germain Bazin, as igrejas mais rudimentares na classificação de Lúcio Costa são as igrejas paroquiais, caracterizadas por planos simplificados formados por capela-mor e nave separadas por arco - cruzeiro.

Segundo o autor, ${ }^{15}$ os tipos de nave única que se desenvolveram na Colônia ao longo do século XVIII, particularmente aqueles destinados às igrejas conventuais e paroquiais, foram os que resultaram de processos de simplificação de concepçóes adotadas pela arquitetura dos séculos anteriores. Para as igrejas conventuais, permaneceu a ampla nave em forma de galpão, com capelas intercomunicantes e, para as paroquiais, essa mesma nave, acrescida apenas de retábulos laterais e anexos complementares formados pela sacristia, consistórios e corredores laterais. A inserçáo desses corredores justificava a necessidade de estabelecer acessos entre sacristia, púlpitos e coro.

Contrário à opinião de Bazin, para quem a origem dos tipos retangulares e unificados do Setecentos é entendida como resultado de transformaçóes das igrejas coloniais dos séculos XVI eXVII está Jonh Bury, que a relaciona com os tradicionais tipos portugueses e italianos de precedência medieval, caracterizados por plantas simplificadas, ambientes compactos e inscritos dentro de um retângulo, traçados austeros, frontispícios com pequenos vãos, portas centralizadas, óculos e presença ou não de torres. Esses tipos náo correspondem, portanto, a processos de modificaçóes e adaptaçóes coloniais, embora tivessem sido amplamente divulgados no Brasil, onde:

(...) a grande maioria das igrejas construídas nas possessōes portuguesas do além mar do final do século XVI até, pelo menos, o início do século XVIII, obedecia a um traçado padrăo, quase estereotipado. Seja na América, na Africa ou Ásia, encontramos a mesma estrutura elementar,

${ }_{14}$ COSTA, Lúcioo "A arquitetura dos jesuítas no Brasil”. In: Revista do patrimônio. Ítalo Campofiorito. Rio de Janeiro, n. 26, 1997. p. 105.

BAZIN, Germain. A arquitetura religiosa barroca no Brasil. Rio de Janeiro: Record, 1986. p. 126.

semelhante à de um galpáo, com uma única porta de entrada, duas janelas alongadas dispostas de Essa composiçáo dos văos em diagonal pode ser relacionada, tanto em Portugal como na Itália, a precedentes medievais(..... ${ }^{16}$

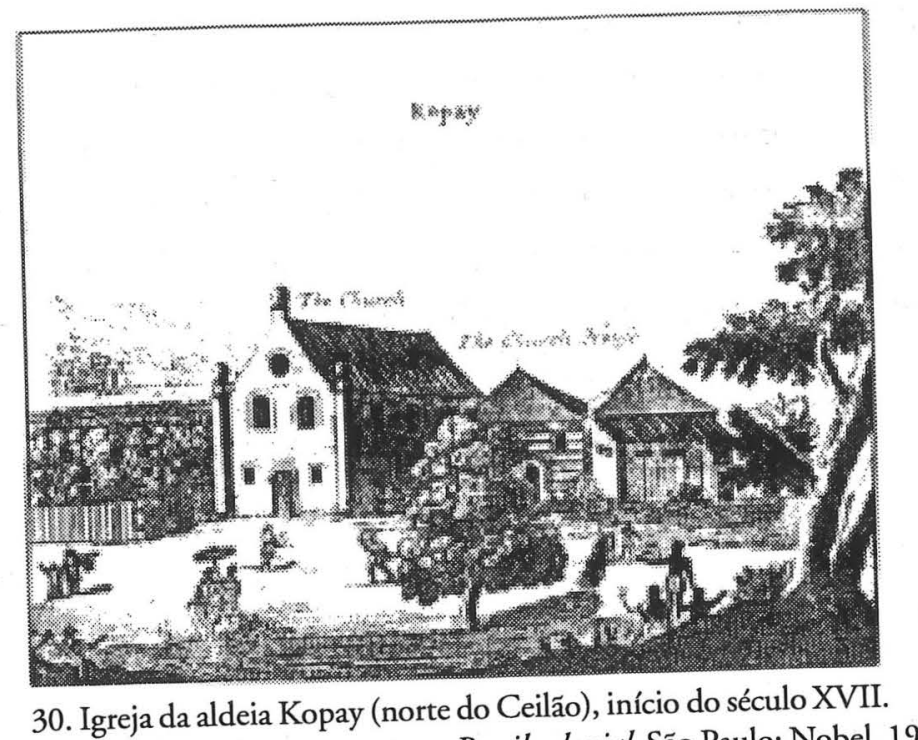

30. Igreja da aldeia Kopay (norte do Ceilao), inctio do seculo Xobel, 1991)

Jonh Bury ${ }^{17}$ diz ainda que esses tradicionais planos simplificados eram acompanhados po

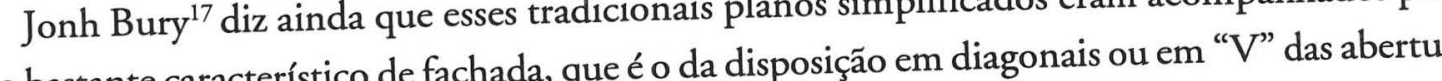
um traço bastante característico de fachach questos" às portas, aproxiras. As igrejas que se configuram com os regulares "vãos em carreira sobrepostos" às poras as fachamam-se das soluçóes que se desenvolveram na metrópole. Também o uso das tores la das se transformou numa prática quase invariável das principais cidades da colonia duranteo XVII embora mais raras em regiōes periféricas.

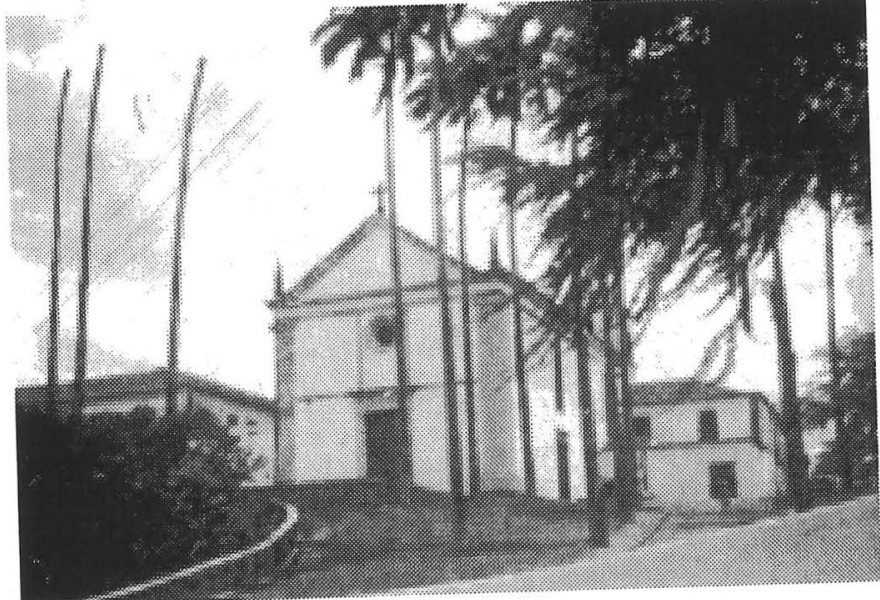

31. Igreja de Nossa Senhora da Graça, Olinda 
Nessa caracterizaçáo tipológica, pode-se reconhecer um significativo número de igrejas e capelas em Goiás, Minas Gerais e em outras regiōes interioranas, onde se ergueram "as capelas mais antigas que pertencem ao tipo provinciano tradicional, com fachadas de composição diagonal, possivelmente derivadas de igrejas paulistas, como as de São Miguel (1622), na província de São Paulo (...)." ${ }^{18}$

Entre os edifícios mineiros, destaca-se a capela do padre Faria, de Ouro Preto, "que, apesar de reconstruída entre 1740 e 1756 com materiais mais resistentes, ainda conserva a simplicidade da primitiva estrutura de madeira e barro. Tais capelas rústicas, que mantêm a tradicional disposição em diagonal dos vãos, eram comuns em Portugal e se disseminaram no império português a partir do final do século XVI"19

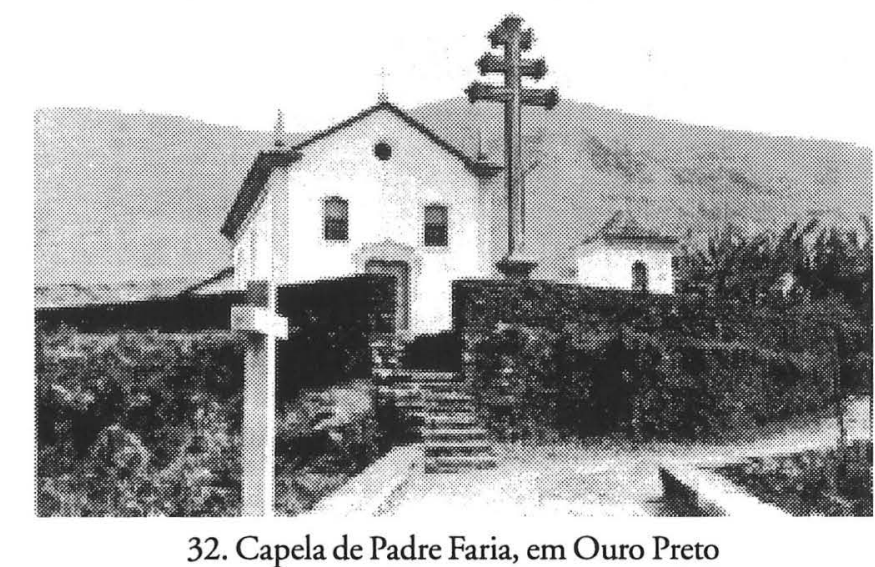

(BURY, Jonh. A arquitetura e a arte no Brasil colonial. São Paulo: Nobel, 1991)

No âmbito geral, as características principais do tipo que mais se multiplicou em Minas Gerais, o de nave retangular, com telhados de duas águas e frontáo triangular, sáo as mesmas da arquitetura que se desenvolveu na Capitania de Goiás, distribuídas em dois grupos: o que inclui as igrejas sem torres, formadas apenas por um galpão à moda das antigas capelas portuguesas; e o que agrupa os exemplares com torres de pesadas proporçōes. Tal configura o quadro de Goiás bastante próximo ao de Minas Gerais, onde se encontram congêneres com e sem torres.

No entanto, a despeito dessa similaridade, há um forte elemento de distinção entre as igrejas mineiras e goianas: estas se apresentam invariavelmente mais pesadas na sua arquitetura, o que permitiu a Eduardo Etzel adjetivá-las "robustas e atarracadas". ${ }^{20}$

Em Vila Boa de Goiás, esse foi o mais antigo tipo que se desenvolveu na regiáo. Foi com o tradicional esquema simplificado, de nave única com anexos, volumetria sóbria e fachada formada por composição em diagonal, táo característico da arquitetura provinciana de Portugal e, posteriormente, de Minas Gerais, que se formou o quadro da arquitetura da capital vilaboense. A Igreja de Nossa Senhora do Rosário dos Pretos, erguida em 1734, por provisão o Sr. D. Fr. Antônio de Guadalupe,

${ }^{18}$ Idem, Ibidem. p. 107.

${ }^{19}$ Idem, Ibidem. p. 72.

20 ETZEL, Eduardo. Arte sacra - berso da arte brasileira. São Paulo: Melhoramentos, 1984. p. 42 apresenta plano unificado e retábulos laterais, com formas simples e compactas, comuns à arquitetura do Setecentos em Portugal e na colônia.

- os modelos de nave única deriados das regióes metropolitanas, como aponta John Bury, ou das do segundo grupo, da classificaçáa de Lúcio Costa. Através de manuscritos e dados iconográficos, pode-se verificar que a planta dessa de Lúcio Costa. Atraves de greja era retangular, formando um espaço que apresentá natureza: nave, arco-cruzeiro em pedra, altar-mor e consistré da capela-mor, em telhado mais baixo, a mento e do Senhor dos Passos e, muito provavelmente, atrás da capela-mor em mentos corographia Histórica da Provincia de Goyaz, o altarsacristia. De acordo colateral, ao lado da Epístola, eram mor, acompanhado por colunas, juntamente com um outs afirma ainda que não se encontravam em os que mais se destacavam na igreja. Quanto aos demais, an a cóneis pela formaçáo e ornaos que mentaçăo desses espaços. ${ }^{21}$

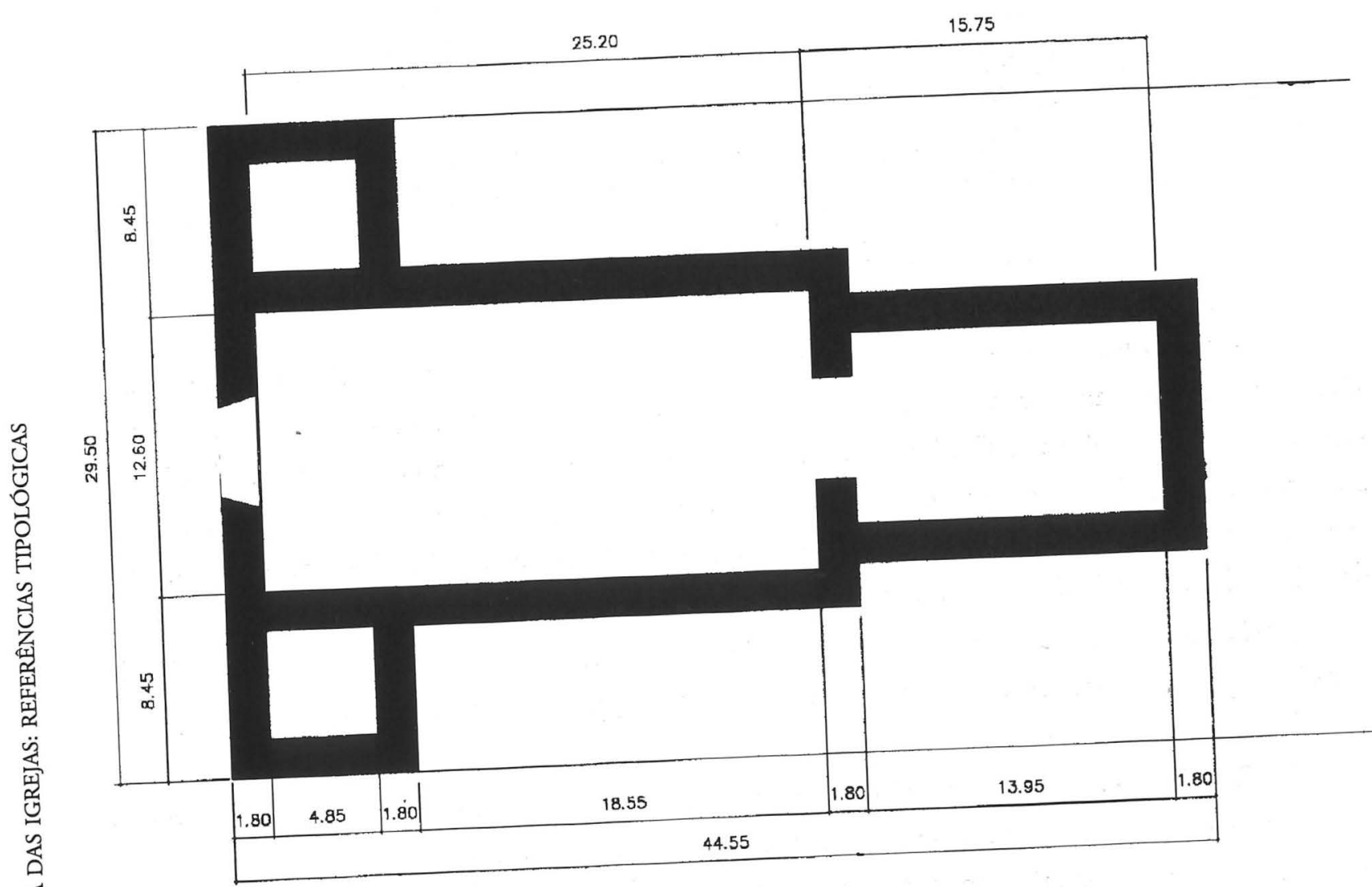
33. Reconstituiçăo parcial da Matriz de Santana a partir de um documento do século Xax
(Desenho Deusa Maria Rodrigues Boaventura)

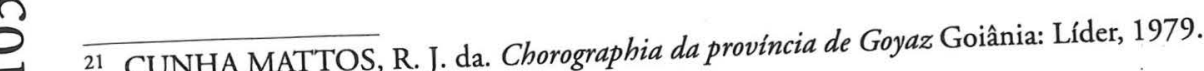


Quanto aos demais traços da Matriz, sua composiçáo volumétrica denuncia uma rigorosa sobriedade formada por um grande bloco compacto. Mesmo que alguns de seus elementos de ornamentação de fachada se aproximem da linguagem barroca, como os sutis arcos da portada e janelas, identifica-se nela um tipo arquitetônico bastante severo, com volumes rígidos, que apresentam estilemas diferentes, caracterizando sobreposiçóes estilísticas.

O frontispício de Santana segue os mesmos padrôes da arquitetura tradicional lusitana, amplamente desenvolvida no Brasil. Possui o volume central formado a partir da composiçáo em diagonal, acrescido de duas torres que náo se inscrevem nos limites da nave e onde se abrem duas janelas. A composição da fachada se completa por quatro colunas que marcam os limites da torre e do volume central, coroado por um frontáo. Esse tipo, ao que parece, pode ser enquadrado naqueles descritos por Bazin:

O corpo central, arrematado por um frontão triangular, se equilibra entre duas torres de elevação moderada, estas acabadas por um pavilhăo de madeira coberto de telhas(...) o corpo da fachada está selado por uma única porta, encimada por duas ou três janelas que iluminam o coro. ${ }^{22}$

A igreja do Rosário dos Pretos ${ }^{23}$ é o segundo exemplar dessa primeira fase da arquitetura de Vila Boa e possui características comuns à sua contemporânea Matriz de Santana, como a disposiçáo dos vãos em diagonal. A documentação iconográfica permite indicar que o plano básico dessa igreja é semelhante ao de outras igrejas da região, com nave única e dois altares laterais. Externamente, a fachada é formada por composição de vãos em diagonal, encimada por um frontão retilíneo, arrematado por telhado de duas águas. Pilares em madeira marcam e delimitam o corpo central em relação às suas duas torres, onde se encontram três janelas dispostas em eixo vertical.
34. Igreja de Nossa Senhora do Rosário

(POLYANTHÉA comemorativa do $50^{\circ}$ aniversário Fundaçăo Dominicana no Brasil. s/d.)

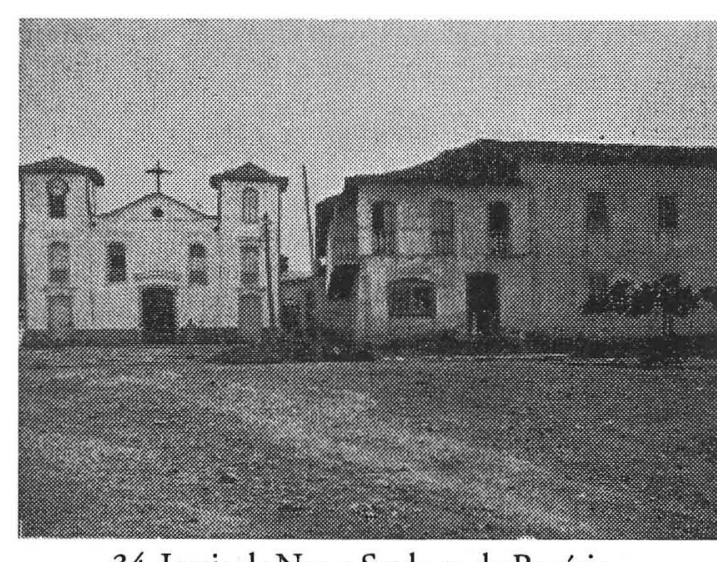

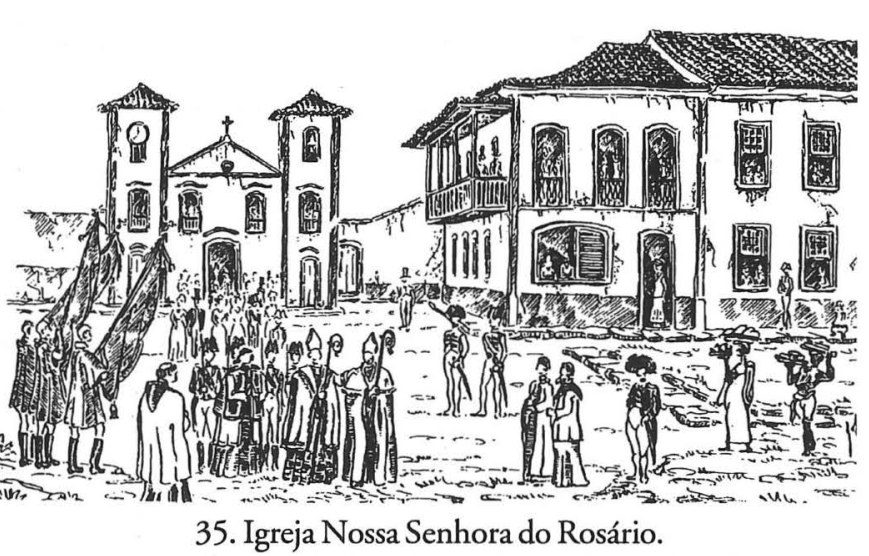

Bico de pena de Tos Senhora do Rosário.
As igrejas construídas em Vila Boa de Goiás na segunda metade do século XVIII são de dimensões reduzidas, com anexos dispostos em diferentes arranjos composicionais, mas seguindo o

22 BAZIN, Germain. Op. cit., p. 198.

23 "Uma das melhores igrejas é ainda a da Boa Morte, construída em 1799, no local onde esteve a casa do descobridor de Goiás, pertencente aos mulatos; depois, a de Nossa Senhora do Rosário, com duas torres, construída pelos negros livres." POHL, Joham Emanuel. Viagem no interior do Brassil. São Paulo: Edusp/ Livraria Itatiaia, 1976. p. 141. programa típico das capelas mineiras. Apresentam-se todas com a mesma configuração: nave única, arco-cruzeiro, com ou sem corredores e tribunas superiores e coro sobre a porta principal. Os frontispícios, na sua grande maioria, caracterizam-se por linhas retas, frontão formado por empenas e cimalhas acima das janelas e porta principal.

Cabe lembrar que esse tipo, no qual há a inserção de anexos, também não é uma criação dos construtores brasileiros, podendo ser visto em igrejas tradicionais de Portugal a partir do século XVI, como a de Santa Maria de Setúbal. No Brasil, essa soluçáo foi amplamente adotada em regióes como Minas Gerais e Goiás, ao longo dos séculos XVII e XVIII, e prolongada até o século XIX, ${ }^{24}$ como observa Marília Maria B. Teixeira Vale em Arquitetura Religiosa no antigo Sertäo da Farinha Podre. Segundo a autora, essa arquitetura é a que caracteriza as típicas construçóes religiosas do período inicial de formação da região central de Minas Gerais e só foi abandonada por volta de 1750. Também é a tipologia predominante em algumas regióes de Sáo Paulo.

As primitivas capelas e igrejas matrizes construídas na região do Norte, da Província de São Paulo, cuja ocupaçáo se deu a partir de fins do século XVIII até o final do XIX, em um processo paralelo de crupaço do Sertão da Farinha Podre, também por povos oriundos do sul e oeste de Minas Gerais, ${ }^{25}$ apresentam as mesmas características formais, como se observa nas matrizes de Ribeirão Preto. Algumas igrejas de Goiás também podem ser enquadradas nessas tipologias acima descritas, o que demonstra a longevidade e a validade desse repertório em várias áreas do pais. ${ }^{26}$

Em Vila Boa, as capelas da segunda metade do século XVIII que se destacam com essa organização geral, apresentando ou não sineiras feitas em madeira, são as de São Francisco de Paula, Santa Bárbara e Nossa Senhora da Abadia.

Sáo Francisco de Paula (1761) possui uma planta de nave única, ladeada por dois amplos corredores, que parecem ter sido acrescentados posteriormente como anexos paroquiais. O plano desenvolve-se inteiramente dentro do tradicional retângulo, com a capela-mor mais estreita e a sacristia do lado esquerdo, com acesso direto à nave e às duas salas situadas à frente. Esses corredores possuem entradas independentes voltadas para a fachada e permitem acesso aos demais ambientes, como consistório, coro, depósito e escada para o púlpito. A sua organização espacial, mesmo com os acréscimos laterais, foi ordenada de forma a denunciar o caráter retangular da planta. O corpo central da capela segue os padróes das tradicionais capelas mineiras, com ampla e profunda capela-mor separada por arco-cruzeiro. A fachada também segue a composiçáo em diagonal, formada por linhas rígidas e de rigor simétrico.

${ }^{24}$ BAZIN, Germain. Op.cit., p. 127.

25 Tipologias da arquitetura religiosa tradicional: Matriz de Santana de Ferros, Porto do Rio Santo Antônio, MG; Igreja Noss Senhora do Amparo, Minas Novas, MG; Matriz do Curral Del Rey, atual Belo Horizonte, MG; Matriz de Sāo Gonçalo, Sãa Gonçalo das Pedras, distrito do Serro; Igreja Nossa Senhora do Nosario de Ge MG. Igreja Nossa Senhora do Rosário, Chapa do MG; (exemplares com duas torres); N. S. do Rosanto, séc. XVill, Beel), MALE, Marllia M. B. Teixeira. Arquitetura religiosa do Século XIX no antigo Sertão da Farinha Podre. Tese de doutorado USP, 1998. p. 71,72

을 26 Op. cit., p. 70 . 
Pav. Inferior
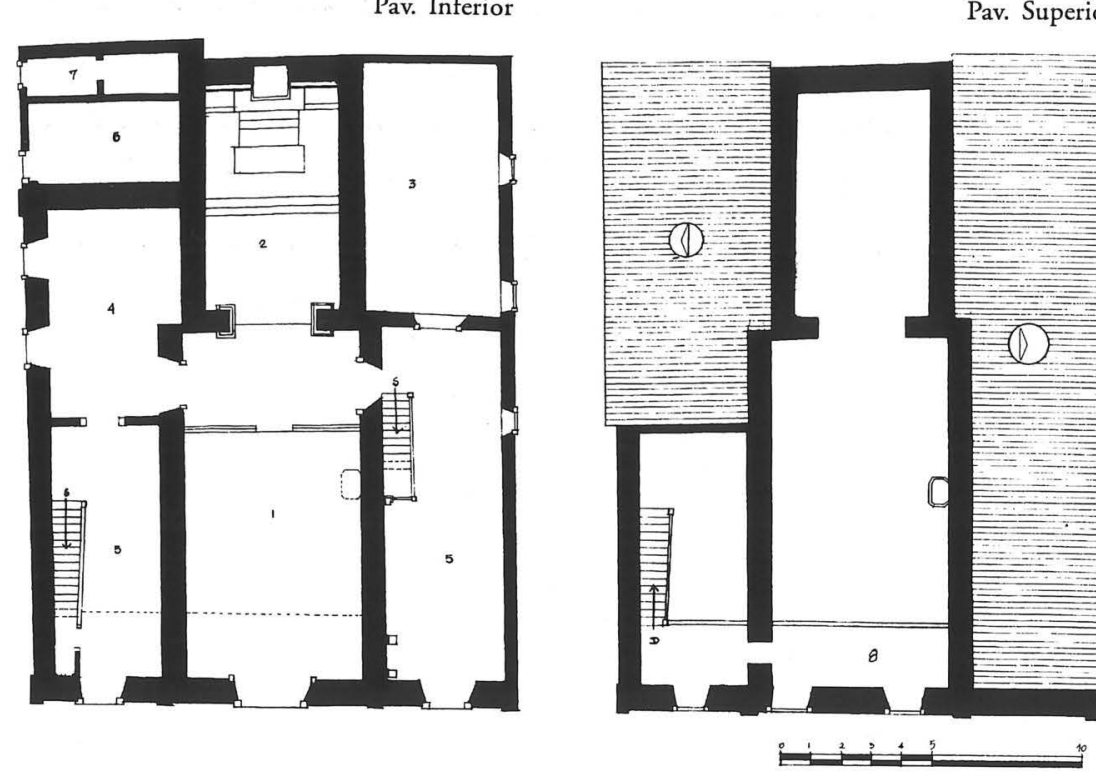

1. nave

3. consistório

4. sacristia

6. depósito
7. sanitartio

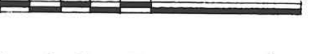

36. Planta do primeiro e segundo pavimentos da Igreja Săo Francisco de Paula.

(COELHO, Gustavo Neiva. Guia dos bens imóveis tombados em Goiás. Goiânia: Fundaçāo Cultural Pedro Ludovico, 1999)

Nossa Senhora da Abadia (1790) apresenta um esquema organizacional diferenciado, assemelhando-se ao plano da igreja da Fazenda de Santo Antônio de São Roque. ${ }^{27}$ Inscritas em um retângulo, encontram-se a nave e a capela-mor de mesma largura. Os anexos desenvolvem-se em outro retângulo de proporções semelhantes ao da nave, à direita do corpo principal, seguidos de uma torre, que se posiciona distante da nave e proporciona ao conjunto um interessante jogo de volumes. A composiçáo da fachada, além de uns poucos ornamentos que coroam porta e janelas, acompanha o tradicional esquema em diagonal, rompendo a rigidez de conjunto com um singelo frontão aberto.
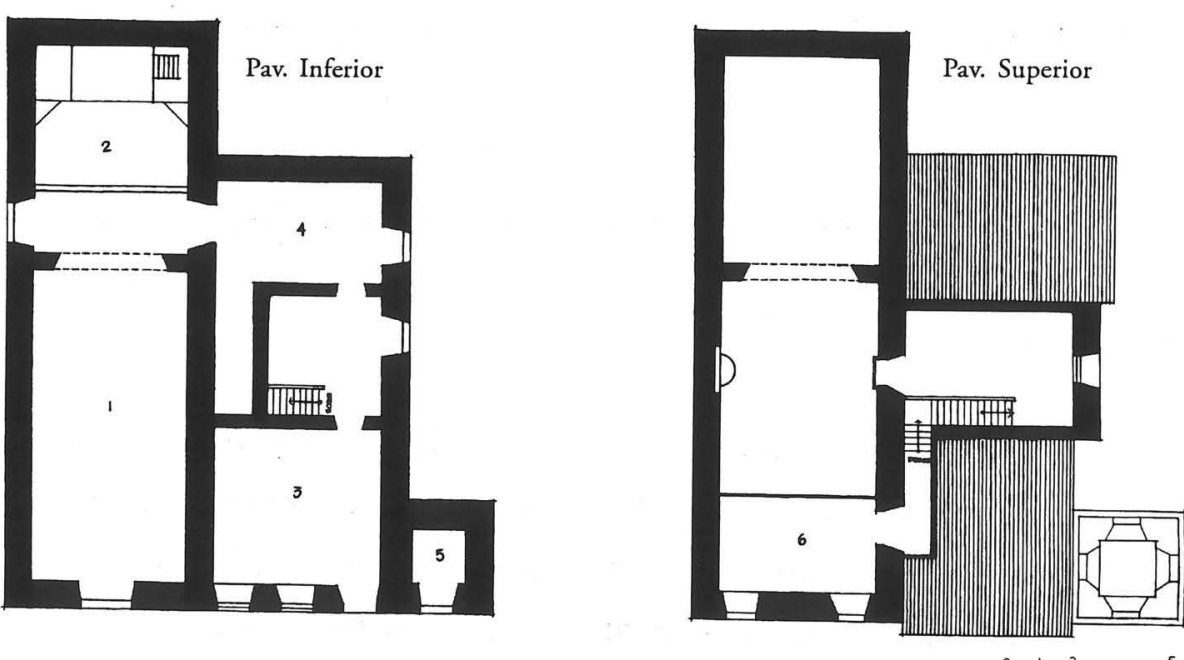

37. Planta do primeiro e segundo pavimentos do Igreja $N$ sess $S$ enhora da $A b$ di. 27 "Esta pequena igreja é quadrangulare e possui uma nave e uma capela-mor da mesma largura, flanqueadas por uma sacristia e un
único e largo corredor do lado da Epistsola." BAZIN, Germain. Op. cit, p. 125.
A última das capelas que apresenta essa tipologia é a pequena Santa Bárbara $(1775),{ }_{,}^{28}$ localizada em acrópole, em local distante das demais igrejas. Como as congêneres, não foge das composiçóes recorrentes de Vila Boa: uma porta e duas janelas dispostas em "V". Sua planta, de reduzidas proporçóes e forma retangular, tem uma capela-mor incrustada como um volume solto que funciona como elemento de separação da nave e da sacristia. A ligação entre os dois ambientes é feita por corredores laterais. $\mathrm{O}$ espaço interno, de extrema simplicidade, não assume muitos contrastes, pela quase ausência de ornamentos.

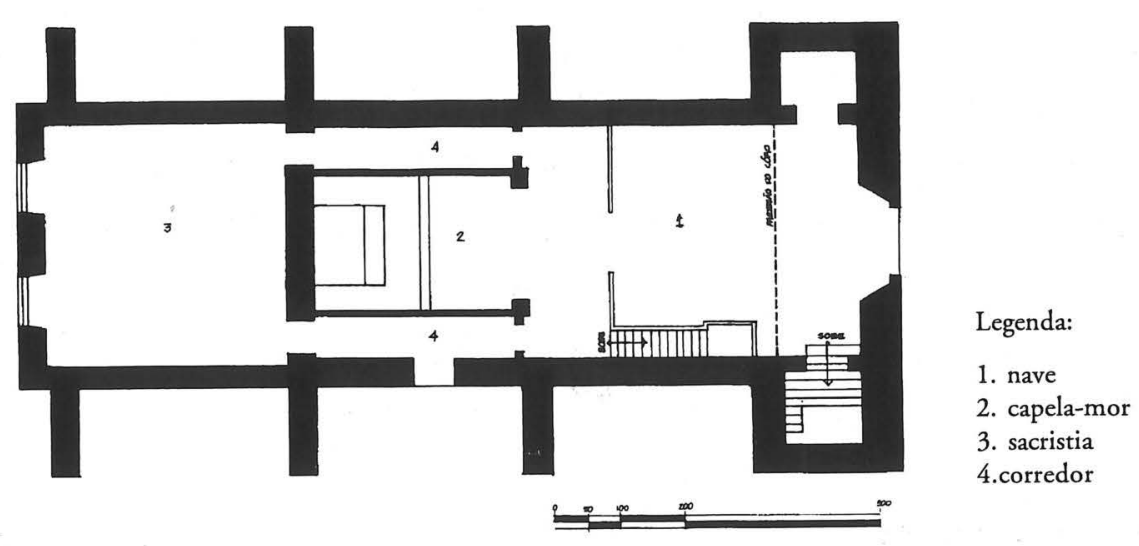

38. Planta da Igreja de Santa Bárbara.

(COELHO, Gustavo Neiva, Guia dos bess imóneis tumbedos com Goíśs. Goiânia: Fundaçăo Cultural Pedro Ludovico, 1999)

Esses são os edifícios que seguiram os esquemas de planos retangulares com volumetria sóbrias e que caracterizaram a arquitetura da região. No entanto, apesar dessa tipologia tradicional, todas elas apresentam pequenas soluçôes diferenciadas, como a capela-mor de Santa Bárbara, os amplos corredores laterais de São Francisco de Paula e a disposição em mais de um bloco dos anexos de 3. Nossa Senhora da Abadia, o que revela as freqüentes adaptaçóes arquitetônicas realizadas pelos construtores goianos.

\subsection{AS IGREJAS DE PLANOS CENTRALIZADOS: OS TIPOS OCTOGONAIS}

\subsubsection{ANTECEDENTES}

$\mathrm{Na}$ Europa, os planos centralizados foram amplamente difundidos com o Renascimento italiano, período das concepçóes arquitetônicas assentes no princípio pitagórico e platônico das relaçóes matemáticas e geométricas entre o micro e o macrocosmo revivescidas pela formaçăo humanista do séculos XV eXVI. Conforme esses valores, adotaram-se novas soluçóes espaciais para as igrejas, ordenadas segundo formas puras, em especial o círculo, cuja harmonia absoluta se igualava à perfeiçáo de Deus. ${ }^{29}$

${ }^{28}$ Cunha Matos afirma que essa capela teve dois campanários. CUNHA MATOS, José Raymundo. Chorographia historica da ${ }^{28}$ Cunha Matos afirma que essa capela teve dois
provincia de Goyaz. Goiânia: Líder, [s/d]. p. 98.

29 WITTKOWER Rudolf La arquitecture en le dede del humanismo. Buenos Aires: Editora Nueva Visión, 1968. p. 11. 
Via de regra, as igrejas renascentistas (...) parecem, pelo menos virtualmente, idênticas ou muito similares por todos os seus lados. E mais, estáo traçadas de tal maneira que seu ponto mais elevado, a cúspide do monumento, por assim dizer, levanta-se sobre o centro do edifício; o centro está coberto por uma cúpula. ${ }^{30}$

A adoção de planos centralizados possibilitava representar, simbolicamente, a ordem e a harmonia da natureza, tornando-se uma soluçáo absolutamente original, diferenciada das antigas igrejas medievais. Nesse novo conceito espacial, Alberti defendeu um ideal de beleza que só poderia ser alcançado com a reformulaçáo e adaptação dos espaços religiosos. No De Re Aedificatória, recomendava figuras básicas para a elaboração de igrejas de planos centrais: o círculo, o quadrado, hexágono, octógono, decágono e dodecágono. Com essas formas e as suas possíveis articulaçóes, resguardando as corretas proporçôes, obter-se-iam conformaçóes espaciais convenientes à ordem divina, cujo centro seria o ponto áureo destinado a Deus.

Essas inovaçôes foram tão amplamente aceitas no mundo italiano que as formas basilicais mereceram pouca atençáo dos arquitetos, ${ }^{31}$ excluídas que foram desse conjunto harmonioso e "ideal" de beleza alcançada pela concordância das partes entre si e com o todo.

Em Portugal, a influência do Renascimento e, conseqüentemente, a adoção das plantas centralizadas não se fez de maneira uniforme. Chegou nas diversas regióes em diferentes momentos, o que torna indispensável conhecer suas origens, seu processo de diversificação, concretização e convivência com a multiplicidade de formas e estilos arquitetônicos. Dessa convivência, várias expressóes arquitetônicas se formaram por sincretismos, assumindo traços do legado tradicional e clássico, resultando uma arte de tendência rígida e austera. Para Horta Correia, esse panorama artístico de elemento de tradição e inovação formou-se a partir do reinado de D. João III, com a política de abertura do país para reestruturaçăo, conforme as exigências dos tempos modernos e a intrínseca consciência do humanismo italiano, aliado do humanismo cristáo. Nesse período,

A arquitetura entra definitivamente no rol dos valores culturais a proteger primeiro, a empreender depois. E deixando de ser apenas instrumento passa a ser entendida como valor em si mesma. ${ }^{32}$

Porém, segundo o autor, ${ }^{33}$ essas inovaçôes, inicialmente, apenas despertaram as soluçôes clássicas, não sendo aceito, de imediato, o rigor canônico italiano. Somente a partir das posteriores leituras de Serlio, foi possível estabelecer uma linguagem mais precisamente renascentista, com concepçóes arquitetônicas que adotaram planos centralizados. ${ }^{34}$

${ }^{30}$ LOTZ, Wolfgan. "Notas sobre las iglesias de planta central del Renacimento." In: La arquitectura del Renacimiento en Itália. Madrid: Hermann Blume Ed., 1985. p. 65.

“(...) para ele, a baślica, como lugar da administraçăo judicial na antiguidade, encontra-se intimamente relacionada com templo. A justiça é um dom de Deus; efetivamente, o homem obtém a justiça divina através da piedade e coloca em prática intimamente relacionados e, neste sentido, a basilica pertence ao domínio da religiäo (...)". WITTKOWER, Rudolf. I arquitectura en la edade del humanismo. Buenos Aires: Editora Nueva Visión, 1968.

${ }_{32}$ HORTA CORREIA, José Eduardo. Op. cit p. 30

${ }^{33}$ Idem. p. 34.

34 "Pensamos que primeiro se terá aceite um capitel fantasiado, a que não correspondia exatamente a noçăo de ordem, mas próxima de uma expressão coŕntia e compósita. Depois advirá, como índice de uuna maturacăác clássica, o jônico. Finalmente,
com a tendência generalizada para a sobriedade do "estilo chăo", o dórico e, sobretudo, o toscano." Idem. p. 34 .
Eses planos desenvolveram-se em pequenas capelas isoladas ou anexas a antigas igrejas, localas ao Sul de Portugal, exemplos da influência italiana: a Quinta da Penha Verde, atribuída a Miguel de Santo Amaro de Alcântara (influência seliana); capela do Paço de Salvaterra (próximo à Palladio e precursora do estilo chão) e capela de Valverde, a mais erudita delas. A alta qualidade arquitetônica desses edifícios não representou um fator impeditivo para a estandardizaçáo dessas formas por todo o território, alcançando as regióes provinciais em séculos posteriores, no contexto da arte mas por tor

De fato, o barroco retoma uma prática que o Renascimento já desenvolvera (Ermida de Santo De

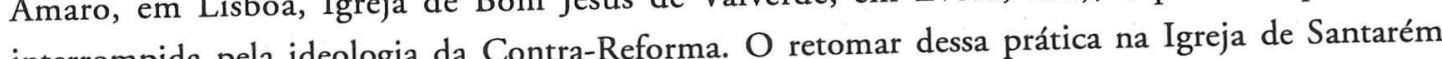
interrompida pela ideologia da Contra-Rerorä. en uma tipologia que, ao lado da decoraçáa, constituirá uma originalidade portuguesa no âmbito do nosso estilo.

\subsubsection{A DIFUSÃO DOS TIPOS OCTOGONAIS NO BARROCO}

As primeiras formas do barroco português surgiram paralelamente à ultima fase da arquiteura chã defrontando-se com a resistência daquelas mais tradicionalmente estáticas, observáveis nas tura châ, defrontando ordenaçôs planimétricas que secomplo pseudo-torsas. Nesse motalhas, de esplendorosos efeitos dourados, azulejaria e as incomuns colunas pseudo-torsas. Nesse momento, a arquitetura subordinou-se à decoração, erigida a primeiro plano do programa construtivo. Posteriormente, espaços mais dinâmicos apareceram em capelas e ermidas que se organizavam através de plantas hexagonais e octogonais. Essa inovaçáo, a de retomar planos centralizados após longo predomínio dos tipos longitudinais, e a crescente multiplicação de pequenas capelas, firmou "a especificidade portuguesa”, como diz José Fernandes:

A especificidade portuguesa resulta da generalizada adoça A número de lados variável. A explicação para o fato costuma encontrar-se na associação com arquitetura militar, conhecida a dupla funçáo dos nossos arquitetos. ${ }^{36}$

Importantes experiências tentadas com espaços centralizados surgiram com as plantas projetadas para a igreja de Santa Egrácia, em Lisboa, no ano de 1682, para a qual foram apresentadas proposta com base no octógono, no hexágono e na cruz grega, todas do tipo centralizado, tendo sido escolhida a tercira par en Barcelos (1707); Barrocas, em Aveiro (1722), S̃o Pedro dos Clérigos, no Porto (1732), entre outras, predominando aí o modelo octogonal.

Esse tipo irá alcançar seu ponto máximo com a Capela de Nossa Senhora das Barrocas (1722), que apresenta cáter mais erudito, distanciado do círculo provincial. Mesmo assim, essas propostas de

35 PEREIRA, José Fernandes. "Resistências e aceitaçăo do espaço barroco: a arquitetura religiosa e civil." In: MOURA, Carlos. 35 PEREIRA, José Fernandes. Resistencias a aceitaçao do, Lishor: Publicaçöes Alfa, 1986. p. $22.2 \mathrm{v}$

(on 
planos centralizados estender-se-ão por "todo o território nacional, sofrendo nuances de interpretaçáo que tanto podem ser variaçóes locais e ruralizadas de temas eruditos, a incompreensão dos mesmos, ou a vontade de afirmar uma força criadora diferenciada. Essas manifestaçôes participam do espírito barroco nacional e as clivagens regionais são náo menos em termos estruturais que no vocabulário decorativo ou nos materiais utilizados. ${ }^{37}$

José Fernandes Pereira cita a permanência desse tipo em regióes tanto metropolitanas quanto provinciais, espalhado largamente por todo o território português. Em Lisboa, a Igreja de Nossa Senhora do Bom Sucesso (1626 e1639), com planta oitavada; ${ }^{38} \mathrm{em} 1626$, Nossa Senhora da Guia, em Alverga; perto de Coimbra, a Capela do Senhor dos Aflitos e a Ermida do Calvário, de plantas hexagonais.

Apesar de a arquitetura barroca nacional se estender por todo o território, até mesmo nas áreas insulares, como os Açores, na região de Aveiro ${ }^{39}$ houve uma verdadeira proliferação de igrejas de planos centralizados. Essa é a regiáo do país com maior densidade de igrejas com tal tipologia. A capela de Santo Estevão, provavelmente reconstruída em 1567, é o mais antigo exemplar do distrito. Ao longo do século XVII, outros exemplares surgiram na regiáo: capela dos Santos Mártires, em forma hexagonal, datada dos finais do século e capela da Madre de Deus, em forma hexagonal.

Outras pequenas construçōes se disseminaram pela região, quase sempre capelas de espacialidade compacta e acentuado ruralismo.

Planos poligonais, inseridos em retângulos, entendidos por alguns autores como uma proposta proto-barroca, por apresentarem soluçóes menos ousadas, também se desenvolveram. São obras que hesitam entre a extravagância da nova linguagem e a força do gosto português, vinculado à sobriedade retilínea. Em geral, esses tipos mantiveram a forma retangular na parte externa, com capela-mor retangular, sendo o seu aspecto mais inovador a nave poligonal. Seguindo essa tipologia, tem-se: a Igreja Menino de Deus, de 1711; Conceição da Praia, Baía, 1739; São João Baptista, Campo Maior, 1724; Navegantes, Cascais, 1711 e Santo Idelfonso, Porto, 1724

Além desse grande número de exemplares em terras lusitanas, os tipos poligonais ou os retangulares com polígonos inseridos seguiram os rumos da expansão do império português, ganhando um decisivo destino sul americano.

Em terras coloniais, tipos mais dinâmicos também conviveram com aqueles de maior rigidez e estaticidade, peculiares a uma arquitetura mais sóbria, "presa a modinaturas renascentistas/maneiristas,

37 PEREIRA, José Fernandes. Op. cit., p. 149

38 "Nestes tempos dificeeis verificamos que ambas as construçōes se situam em zonas marginais a qualquer centro urbano importante, Prop civil." In: MOURA, Carlos. (org.): Historia da arte em Portugal: o limiar do barroco. Lisboa: Alfa, 1966. p. 22.

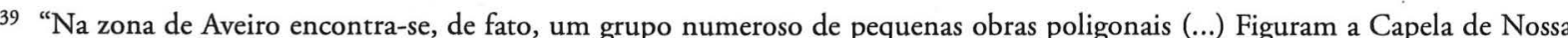
Senhora das Areias, a Capela de Santos Mártires e a Capela da Madre de Deus, na própria cidade aveirense. Apesar de a simplicidade ser a característica dominante de todas elas, nota-se um crescente cuidado decorativo nas citadinas em oposiçăo às rurais". Op. cit., p. 25 .

PEREIRA, José Fernandes. Arquitectura barroca em Portugal. Lisboa: Biblioteca Breve, 1992. p. 160. a esquemas gerais mais arcaicos, simplificados (...), que George Kubler analisou, denominando de . tuídas por outras mais livres e sinuosas, com efeitos de contrastes e composiçóes que não se preocupavam tanto com simetrias e equilíbrio.

Também no Brasil, o barroco foi introduzido pelas talhas policromadas, em retábulos que, posteriormente, espalharam-se pelas capelas-mores, arcos-cruzeiros e naves. As mais antigas capelas que ilustram esse período são as capelas do Mosteiro de São Bento, no Rio de Janeiro e a Dourada, dos Terceiros Franciscanos do Recife. Na terceira década do Setecentos, as talhas romperam com os esqueTerceiros mas anteriores e passaram a ser produzidas em composiva nos tetos. Simultaneamente, surgiram, nas regióes litorâneas, igrejas de naves poligonais e curvas - Igreja Nossa Senhora da Glória do Outeiro do Rio de Janeiro (1714/1739), Igreja de Nossa Senhora da Conceiçáo e Boa Morte (-?-1758), Rio de Janeiro; Igreja de Nossa Senhora da Lapa dos Mercadores (1747), Rio de Janeiro; Igreja Nossa Senhora Máe dos Homens (1752-90), Rio de JaneiSéo dos Clérigos do Recife (1728/ 1759), ${ }^{42}$ e a de Nossa Senhora da Conceição da Praia de ro; São Pedro dos Clérigos
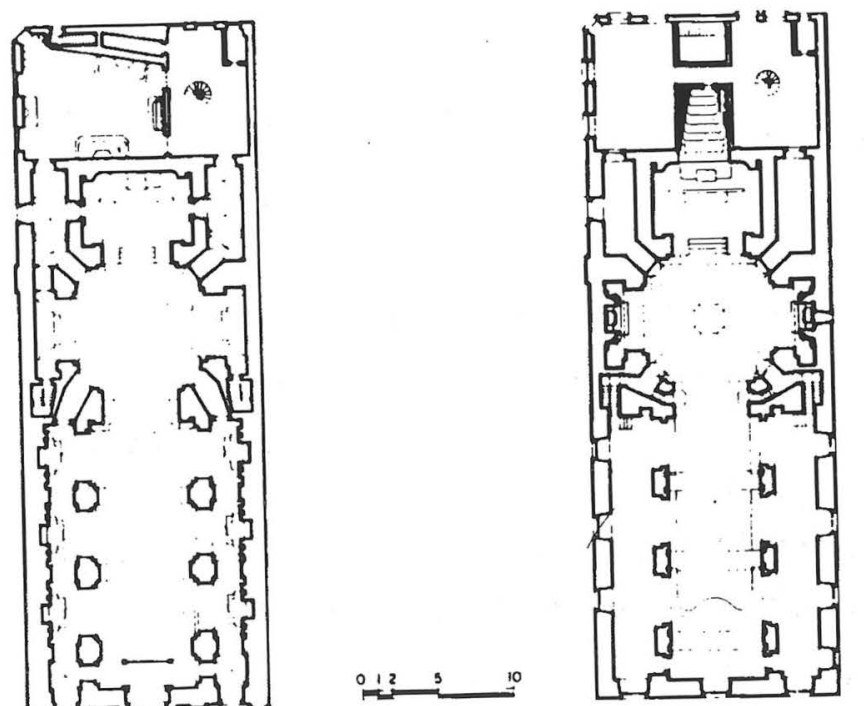

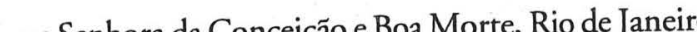
(Revista Barroco, n. 15) ${ }_{41}$ SILVA TELLES, Augusto C. da. "O barroco no Brasil. Análise da biografia crítica e colocaç̧a Segundo Augusto C.da Silva Telles,
escola Borromínica". Op. cit., p. 130 .

${ }^{3}$ Neste texto, foram adotados as referências de datas indicadas por Myriam de Oliverira, discordantes das de Silva Telles em $O$ Barroco no Brasil, onde se lế: "Igreja de N. Senhora da Glơria do Oua de Salvador (1736/65). Op. cit., p. 129.

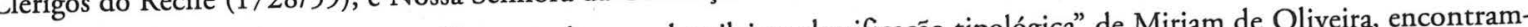
No artigo "Plantas poligonais e curvilíneas no barroco brasileiro: classificaçäa tipologica" de Miriam de Oliveira, enco (1728se as seguintes datas: "Nossa Senhora da Cenir (2-1758), Nossa Senhora Măe dos Homens (1752-90), Nossa Senhora do Pilar 2), Conceiçăo e Boa Morte do Rio de Janeiro (?-1758), Nossa Sre Preto (1727)." Op. cit., p. 300. 

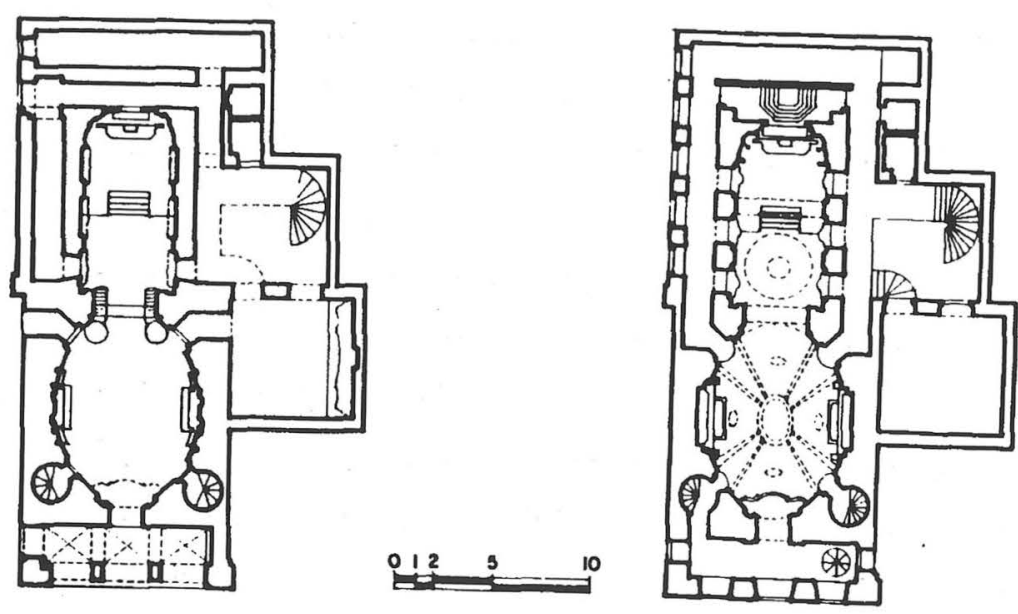

40. Planta baixa do primeiro e segundo pavimentos da Igreja de Nossa Senhora da Lapa dos Mercadores, Rio de Janeiro. (Revista Barroco, n. 15)
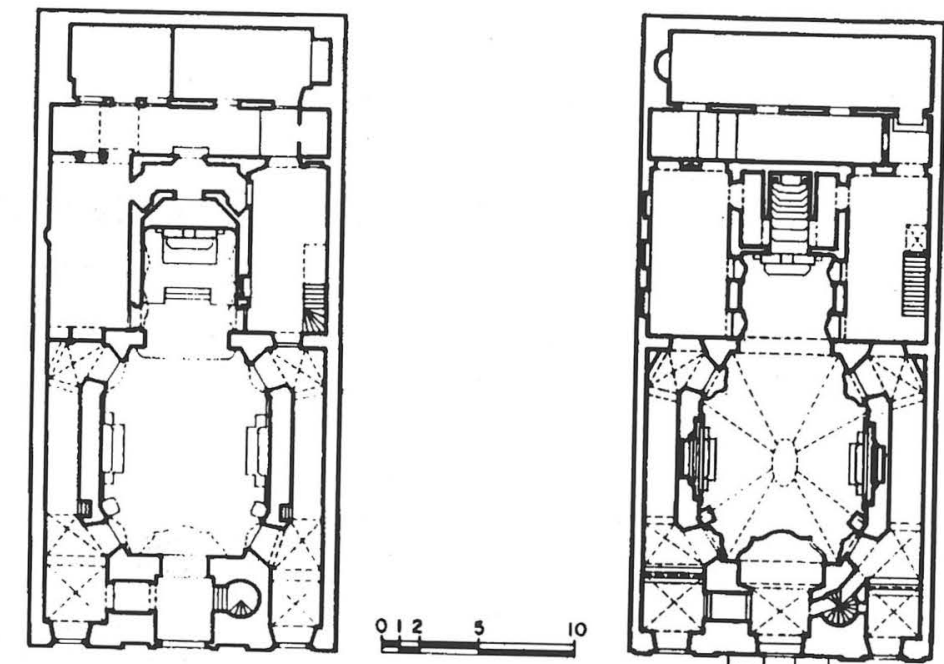

41. Planta baixa do primeiro e segundo pavimentos da Igreja de Nossa Senhora Mãe dos Homens, Rio de Janeiro. (Revista Barroco, n. 15)

Em regiôes centrais, como Minas Gerais, o quadro tipológico diversificou-se, com plano retangulares e centralizados mais elaborados de influência borromínica, como: a Matriz de Nossa Senhora do Pilar de Ouro Preto (inaugurada em 1731), Igreja do Rosário dos Pretos de Ouro Preto de São Pedro dos Clérigos de Mariana, as duas anteriores a $1762 .{ }^{44}$

Paralelamente, surgiram os octogonais, mais simples e que, ${ }^{45}$ segundo Myriam de Oliveira podem ser vistos como a "especificidade portuguesa", por sua associaçãa evidente com a arquitetura

$\overline{44}$ Idem. p. 132.

45. Para Selma Melo Miranda, a capela setecentista de São José de Minas Novas, de planta com nave octogonal e capela-mor hexagonal, pode ser considerada, em Minas Gerais, a irradiadora "das experiências do Nossa Senhora do O em Sabaré é Nosta Rosário em Santa Bárbara e S̄̃o frou com corredores laterais à nave ou à capela-mor, no caso das capelas de Nossa Senhora do

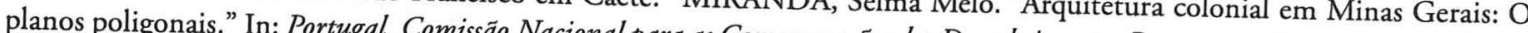

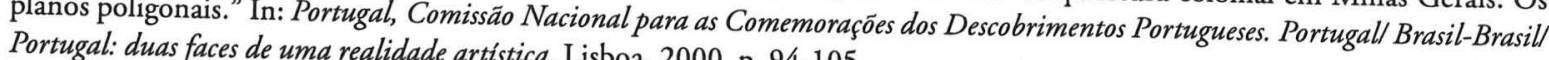

militar, que constituía a formação básica dos arquitetos do país. "É, aliás, sintomático que a maioria das igrejas de plantas poligonais construídas no Brasil tenha, em sua origem, engenheiros militare portugueses, ao oposto das curvilíneas, desenhadas quase todas por profissionais com informaçáo erudita, mas sem formação oficial em arquitetura e construçoes, como o Alejadinho. ${ }^{46}$

Ainda segundo Myriam de Oliveira, foram os tipos poligonais inseridos em retângulos os que alcançaram maior aceitação na arquitetura brasileira, como atestam: a igreja ouro-pretana Nossa Senhora da Conceição de Antônio Dias (1727); a igreja de São Pedro dos Clérigos do Recife (1728), desenhada por um mestre - pedreiro, mas com risco avaliado por engenheiros militares; Igreja da Conceição da Boa Morte do Rio de Janeiro (?-1758), com risco atribuído a outro engenheiro militar, José Fernandes Pontes Alpoim; a nave da Igreja carioca de Nossa Senhora Mãe dos Homens (175290); e a elaboradíssima Nossa Senhora do Pilar de Ouro Preto (1731-74).

$\mathrm{Na}$ região de Sabará, movimentações em fachadas, que configuram seção octogonal, são encontradas em Nossa Senhora do $\mathrm{O}$ e em várias outras pequenas capelas mineiras, "principalmente na segunda metade daquele século [XVIII] - Santa Rita do Serro, Rosário de Itabira, Arquiconfraria de Mariana, São Francisco de Caeté, Rosário de Santa Bárbara, Rosário de Conceição de Mato Dentro." 47

Em São Paulo, de acordo com Benedito Lima Toledo ${ }^{48}$ duas igrejas apresentam-se com esse tipo de planta: Nossa Senhora da Luz e a capela da Ordem Terceira de São Francisco. Acresce-se ao exemplares paulistas a pequena Pilar de Taubaté, iniciada em 1749, considerada por Selma Miranda o tipo paradigmático da série mineira. ${ }^{49}$

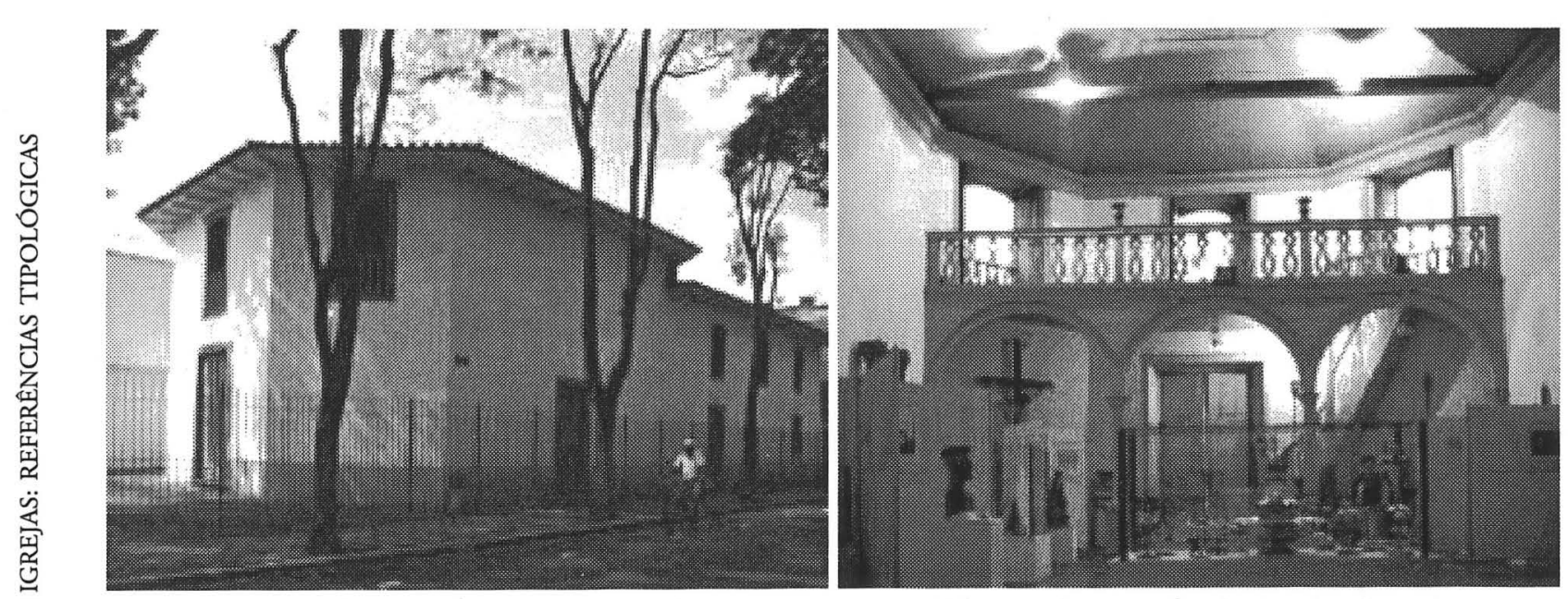

42. Fachada e interior da Igreja de Taubaté em São Paulo. (Arquivo particular de Hugo Sagawa)

$\overline{46}$ MYRIAM, Andrade Ribeiro de Oliveira. "Plantas poligonais e curvilíneas no barroco brasileiro: Classificaçăo tipológica." In Revista Barroco. Belo Horizonte, n. 7. p. 300 .

AVILA, Afonso. "Igrejas e capelas de Sabará". Revista Barroco. Belo Horizonte, n. 8, p. 25.

? 48 TOLEDO, B. L. de. "Igrejas paulistanas de planta octogonal". In: Revista da USP. Săo Paulo, n. 2, 1986. p. 123.

- 49 MIRANDA, Selma Melo. Op. cit., p. 94-105. 

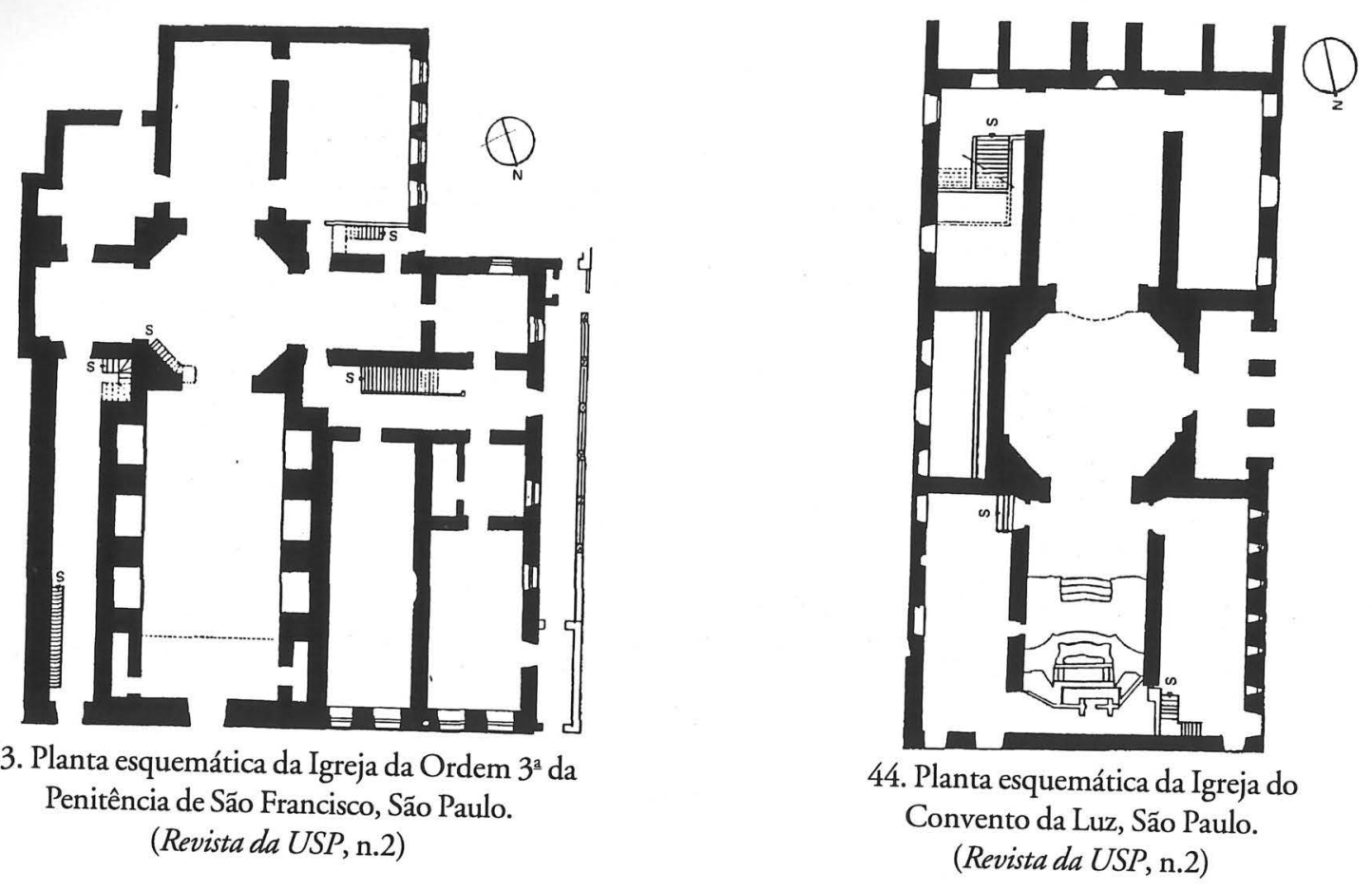

Em Vila Boa de Goiás, são dois os exemplares do grupo das octogonais inseridas em retângulo: Nossa Senhora da Boa Morte (1762-1779) e Nossa Senhora do Carmo (anterior a 1786).

A primeira obedece, em seu frontispício, ao esquema das tradicionais capelas mineiras, com composição que se equilibra pela disposição dos seus vãos - uma porta central, duas janelas a altura do corpo e uma terceira com sacada ao centro. Essas mesmas janelas se enquadram entre quatro colunas, com capitéis que se fundem à cimalha. No frontão ondulado, encontram-se os ornatos que habilmente suavizam a rigidez da composição severa. Nas duas fachadas laterais, a cimalha continua apenas na extensão do volume mais alto. No mais baixo, não se encontra nenhum elemento de arremataçãa entre a parede e a cobertura em duas águas. Complementam essas fachadas duas janelas, com vergas ligeiramente curvas, que se abrem para as tribunas.

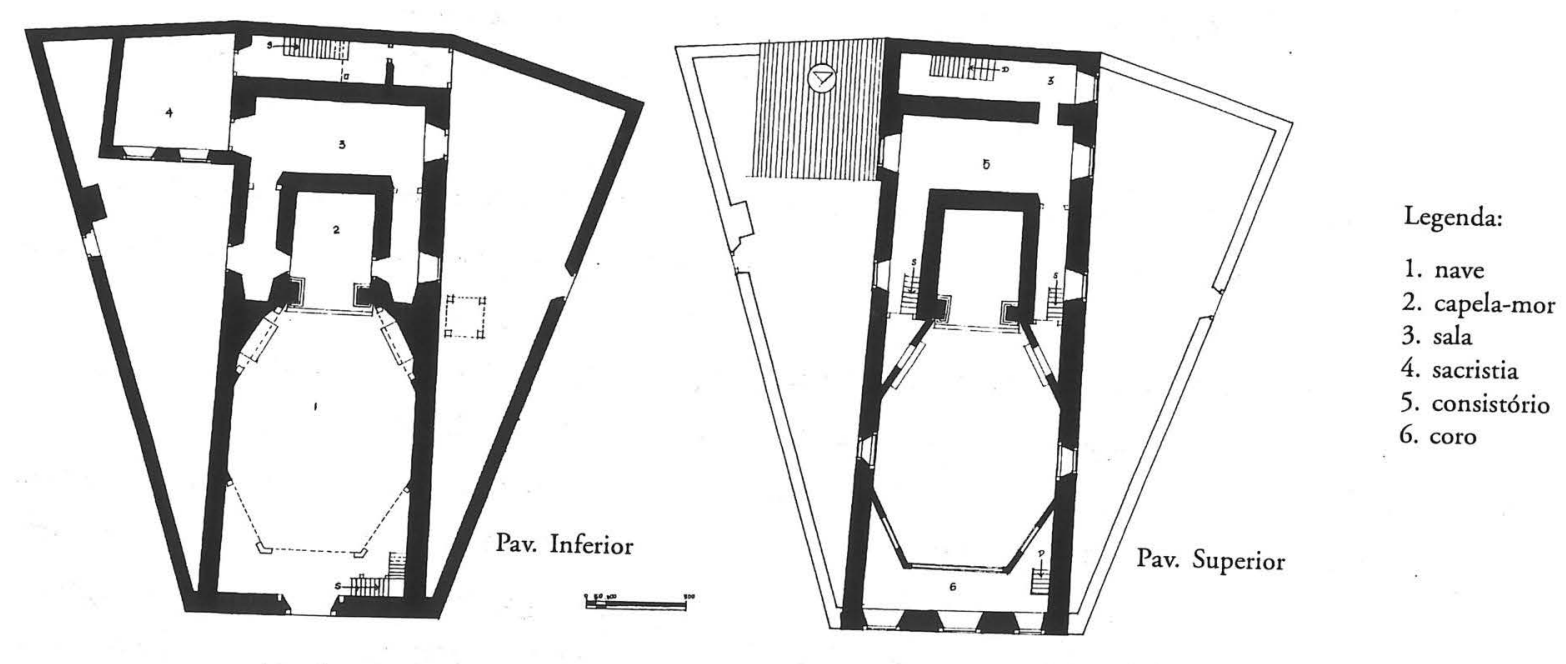

45. Planta do primeiro e segundo pavimentos da Igreja Nossa Senhora da Boa Morte.
(COELHO, Gustavo Neiva Guia dos bens imóveris

consistório

o Ludovico, 19999$)$
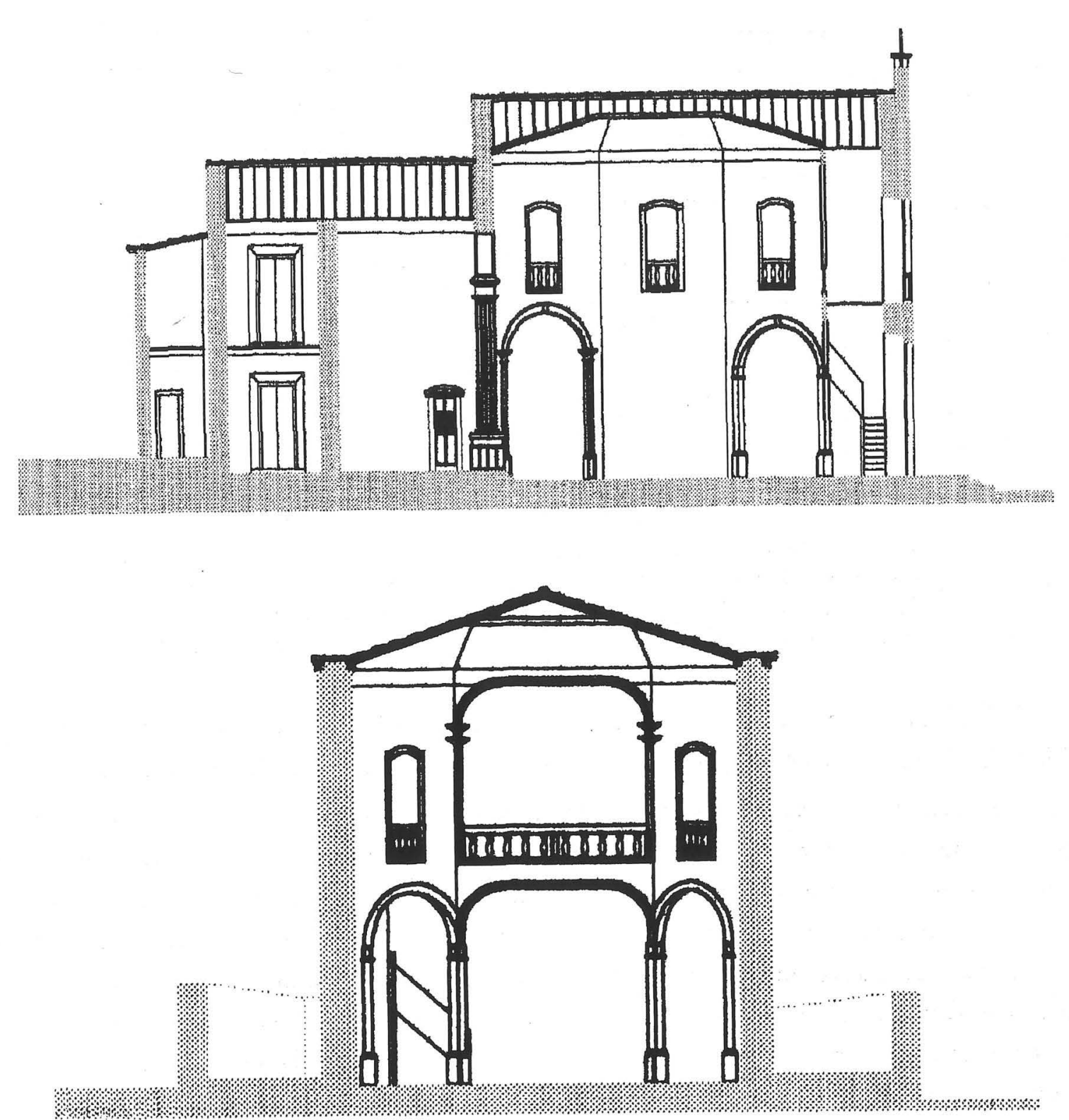

46. Cortes lateral e frontal da Igreja Nossa Senhora da Boa Morte.

(Esquema elaborado a partir do levantamento do SPHAN de Brasília)

A planta se desenvolve dentro de um risco retangular básico, definindo um único volume externo, de linhas rígidas e alturas diferenciadas. Internamente, o espaço se dinamiza a partir da forma octogonal, que corresponde à nave da capela, constituída pelas inclinaçóes dos dois retábulos laterais e por uma sucessão de três arcos, formados por colunas delgadas, que sustentam o coro. A capela-mor, de forma retangular é sepad por um arco-cruzeiro e ladeada por corredores laterais que dáo acesso à sacristia, desenvolvida transversalmente à capela. Atrás da sacristia, encontra-se uma escada que dá acesso ao pavimento superior onde estáo o consistório, as tribunas e um coro de pequenas proporçóes, forma irregular e parapeito em balaustrada. O forro, acima da nave, segue a mesma disposiçáo octogonal forma irregular e parapeito em balaustrada. O forro, acima da nave, segue a mesma disposiçáo octogonal n e reforça a dinâmica do espaço interno. Porém, mo 
distribuição espaciais que seguem o tradicional esquema simplificado das igrejas do segundo grupo da classificação de Lúcio Costa.

Nossa Senhora do Carmo não difere, nos seus aspectos externos, do esquema tipológico das capelas rurais mineiras. Essas, geralmente, "apresentam frontispício extremamente despojado e desprovido de torres, com aberturas em óculo ou pequenas janelas na empena, à altura do coro, quando este existe (ex. Santo Antônio do Pompeu), servindo uma das aberturas às vezes como sineira (ex. Roś́rio do Cuiabá), mas sempre com função também de iluminação e raramente aspirando ao desempenho decorativo como se dá no óculo em rosácea”. ${ }^{50}$

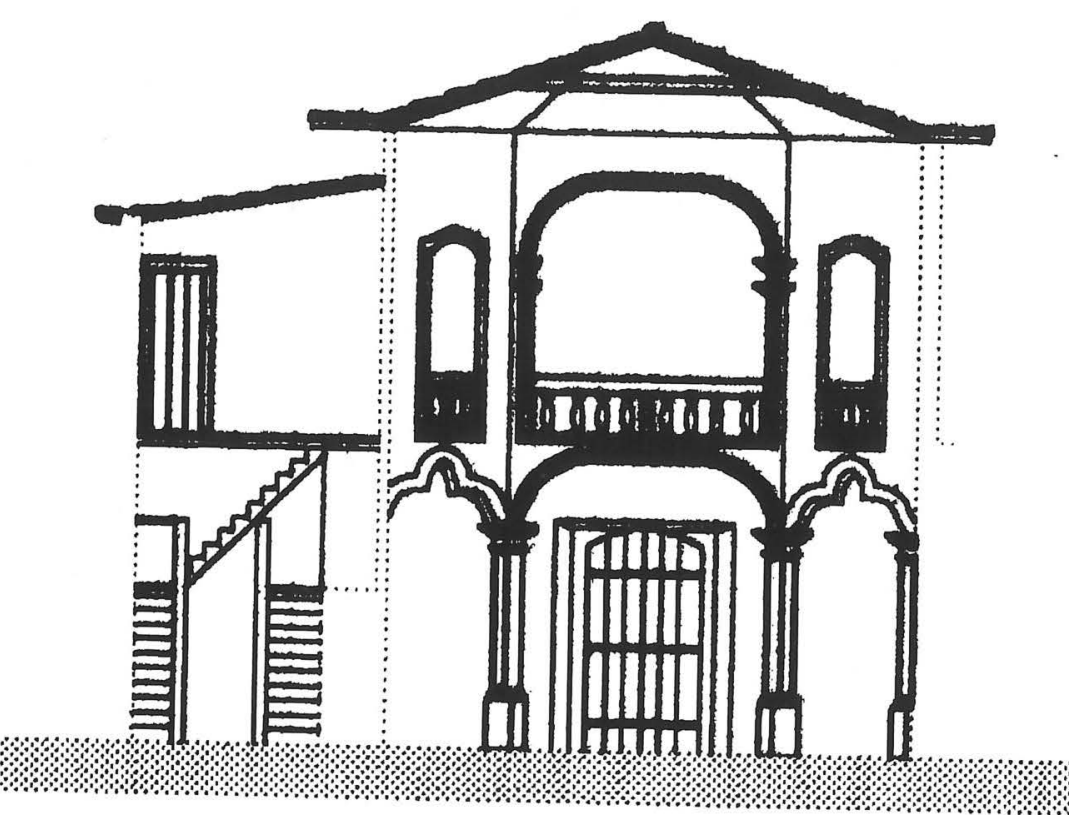

47. Corte da Igreja Nossa Senhora do Carmo.

(Esquema elaborado a partir do levantamento do SPHAN de Brasilia)

Não obstante essas características externas semelhantes às das capelas mineiras, internamente é o edifício religioso que possui a mais complexa planta de todos os edifícios em estudo, formada po uma nave octogonal. No entanto, a articulaçáo entre seus espaços internos ainda permanece com o mesmo esquema tradicional, em duas seções básicas: o octógono regular correspondendo a nave; $\mathrm{e}$ segunda seção, subdividida em três cômodos: a capela-mor, de formas retangulares, e os corredores, projetando-se lateralmente. Demais compartimentos irregulares, como os que se desenvolvem no piso superior, compõem o conjunto interno. Distingue-se das demais capelas, pela sua nave octogonal formada por arcos trilobulados e o coro, em contraste com o restante do conjunto. Para maior acentuação da dinâmica espacial da nave, Nossa Senhora do Carmo conta com altares trabalhados e o apainelado do forro. Do lado direito da nave, a igreja possui um volume em dois pavimentos, sendo feito aí o acesso às tribunas e ao púlpito. Do lado esquerdo, existe, por trás da parede da fachada, um pátio interno, cujo acesso é feito através da sacristia. Contribuem para maior movimentação do espaço, duas janelas de tribunas que se dispóem, para quem está no centro da nave, respectivamente, sobre um dos altares laterais e sobre o púlpito.

Por fim, convém ressaltar que as igrejas de Nossa Senhora da Boa Morte e Nossa Senhora do Carmo, de plantas octogonais, possuem uma organização de espaço interior similar à das igrejas de plano retangular, respeitando a mesma articulaçáo entre coro, nave, altar-mor, etc. Contribuem, portanto, para a garantia e a manutençáo dos espaços litúrgicos, apregoadas desde as Instructiones Fabricae et Supellectilis Ecclesiasticae de São Carlos Borromeu, e reafirmam as aproximaçóes de Vila Boa de Goiás com outras regiōes da Colônia e da própria Metrópole, onde os tipos octogonais, plenos de espacialidade, paulatinamente adquiriram predileção sobre os retangulares. 


\section{O N C L US Ã O}




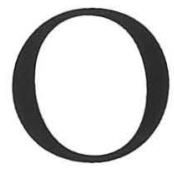

estudo das igrejas setecentistas da antiga capital de Goiás vincula-se à compreensão de sua história urbana. Os edifícios religiosos foram cruciais na formação, orientação e configuração dos espaços urbanos do Brasil Colônia. Marcaram de forma significativa a paisagem vilaboense, física e simbolicamente, destacando-se como focos de referência urbana. Entretanto, ao longo do século XVIII, essa arquitetura se relacionou com a cidade sob formas diferenciadas, evidenciando a diversidade das práticas urbanísticas que marcaram a chamada Expansão Ultramarina, para a qual o edifício religioso sempre foi um elemento organizador.

O Arraial de Santana estruturou-se pela mais tradicional forma de fundar cidades, com a igreja assumindo papel preponderante na organização urbana, articulando e ordenando os espaços hierarquicamente, conforme a estrutura social da época. A formação do Largo da Matriz correspondeu à fase inicial dessa prática. Consagrado pela igreja-mãe e circundado pelas habitaçóes das pessoas mais ilustres, foi o local mais dinâmico do povoado, lugar de exercício de múltiplas funçóes, onde se confundiram as fronteiras do sagrado e do profano. Subordinado a esse local fundacional, o Largo do Rosário, com sua Igreja dos Pretos, se orientou, ainda nessa fase, segundo a posiçáo da Matriz e abrigou em suas proximidades a populaçáo parda e forra. Foi o segundo espaço do Arraial, definindo um eixo bipolar com respeito ao Largo da Matriz, característico das práticas urbanas mais tradicionais.

Com a fundação de Vila Boa, procurou-se inaugurar uma nova lógica de formaçáo de cidades, na qual a praça, definida previamente por arruadores, compareceu como elemento estruturador para abrigar dois edifícios representativos dos poderes estatal e eclesiástico: a Matriz e a Casa de Câmara e Cadeia. Antepostos, esses edifícios marcaram a tensão entre essas duas instâncias de poder. Entretanto, a consolidação da Vila revelou inúmeras resistências para com a implantaçáo integral do seu plano, mantendo apenas, como sinal concreto dessa nova lógica, a demarcaçáo do Largo do Chafariz e a construção da Casa de Câmara e Cadeia. Ainda assim, essas alterações inauguraram um novo espaço rival do antigo povoado, redesenhando as relaçóes entre o político e o religioso. Nessa nova ordem, as igrejas não se orientaram mais por um único foco de atenção, ou seja, o antigo largo da Matriz, mas disputaram melhores localidades relacionadas ao espaço da vila como um todo. 
Essas resistências, distorçóes e desvios do plano de fundação foram os principais alvos de reformas posteriores, que se realizaram segundo princípios de maior regularidade do traçado, revelados nas propostas de realinhamento de estruturas anteriores e expansão urbana, e por um código de posturas para a construçáo de novas casas. Nessas mudanças, as capelas erguidas em locais privilegiados e de cotas mais elevadas apresentaram relaçóes diferenciadas com o espaço urbano. Firmaram-se seguindo as imposiçôes do alinhamento e apontando para os novos valores dessa ordem regular de traçado. E a Vila redefiniu, uma vez mais, o significado do domínio público urbano, então exaltado pelos princípios da "razão", da "cultura útil", da "promoçăo das luzes", simbolicamente identificados com a construção do passeio público e do Horto Botânico, e circunscreveu as dimensões espaciais do sagrado aos adros e interiores das igrejas e capelas.

As legislaçóes e as organizaçóes sociais também influíram diretamente na edificação e disposiçăo das igrejas no interior da cidade, marcando, no espaço, os traços de uma sociedade hierárquica, estruturada por irmandades e confrarias, que se vinculavam aos respectivos recintos religiosos. As escolhas dos locais para as implantaçôes das igrejas, bem como as qualidades formais da arquitetura fizeram parte desse jogo social. A monumental Matriz de Santana, erguida no local fundacional, náo só acolheu a Irmandade do Santíssimo Sacramento e outras, como também agregou, ao seu redor, as residências das pessoas brancas e de maior poder. Nesse mesmo Largo ergueu-se também a capela de Nossa Senhora da Boa Morte, inicialmente prevista para os militares e entregue posteriormente à Irmandade dos Pardos. Em contraponto, o Largo do Rosário, com sua Igreja dos Pretos, articulou-se hierarquicamente em relaçáo ao principal espaço da Vila, marcando claramente a ordem social do período colonial.

Essa mesma hierarquia norteou a organização e a lógica dos mestres e artesãos vilaboenses no seus canteiros de obras, com intervençóes construtivas pontuais resultantes de uma dinâmica de trabalho marcada por diferentes grupos e especializaçóes. Conseqüentemente, as igrejas se caracterizaram por descontinuidades estilísticas entre seus arcabouços, fachadas, arcos-cruzeiros, etc, derivadas desse modo de organização do canteiro. As capelas de Nossa Senhora da Boa Morte e de Nossa Senhora da Abadia são, nesse sentido, exemplares. A traça foi um instrumento de trabalho imprescindível na construçáo de algumas das capelas de Vila Boa, mantendo compromissos estreitos com a divisáo hierárquica do trabalho e sua lógica de "concepção arquitetônica". No entanto, essas descontinuidades estilísticas foram atenuadas pelo respeito que os construtores mantiveram pela ordem dos espaços litúrgicos e sua hierarquia de valores, tal como no tratamento dispensado aos altares-mores, arcos, púlpitos e portadas que, destacando-se qualitativamente, contribuíram para a mesma manutenção e valorização hierárquica dos "lugares" no interior da igreja.

Nas construçốes religiosas de Vila Boa de Goiás, predominaram tipos arquitetônicos genericamente agrupados em edifícios de planos retangulares e octogonais. A recorrência dos tipos, cuja adoçáo nunca se deu, evidentemente, de forma repetitiva e automática, abre novas perspectivas ao estudo da arquitetura. Se cada escolha pressupóe soluçóes diferenciadas, o referencial, no entanto, impōe uma consideração de maior abrangência. De onde se conclui que Vila Boa setecentista manteve sincronia com outras regióes da colônia, sobretudo as capitanias de São Paulo e Minas Gerais, bem como com Portugal, contradizendo argumentos recorrentes que a balizaram pela idéia de isolamento.
Com as novas documentaçóes e reflexóes levantadas, o presente trabalho náo pretendeu Ulimar as investigaçóes e dúvidas sobre a arquitetura religiosa de Vila Boa de Goiás, mas desenvolver outras interpretaçōes de seus edifícios, cuja singeleza há tempos tem alentado visóes singulares sobre nossa história regional. 


\section{BIBLIOGRAFIA}

ALVIM, Sandra. Arquitetura religiosa colonial no Rio de Janeiro. Rio de Janeiro: Editora da UFRJ/ IPHAN, 1999. 1 e 2 v.

ALVES, Marieta. Dicionário de artistas e artifices na Bahia. Salvador: UFBA, 1996.

AMARAL, Aracy. A bispanidade em São Paulo. São Paulo: Nobel, 1981.

ANDRADE, F. P. D. Subsidio para ao estudo da influência da legislação na ordenação e na arquitetura das cidades brasileiras. Tese de doutorado. São Paulo: Escola Politécnica de S. Paulo, 1966.

APARÍCIO, João Paulo da Silva. Governar no Brasil colonial: A administração de Luís da Cunba Menezes nas capitanias de Goiás (1778-1783) e de Minas Gerais (1783-1788).Dissertação de mestrado. Lisboa: Universidade de Lisboa. Faculdade de Letras, 1998.

ÁVILA, A. Barroco - teoria e análise. São Paulo: Perspectiva, 1997.

AZEVEDO, Aroldo de. Vilas e cidades do Brasil colonial. Săo Paulo: Faculdade de Filosofia Ciências e Letras da USP, 1956.

BAZIN, Germain. A arquitetura religiosa barroca no Brasil. Rio de Janeiro: Record, 1986.

BELLUZZO, Ana Maria de Moraes. Artesanato arte e industria. Tese de doutorado. São Paulo: FAUUSP, 1998.

BERTRAN, Paulo (org.). Notícia geral da capitania de Goiás. Goiânia/Brasília: Editora da UFG e UCG, Solo Editores, 1997. 1V e 2 V.

BITENCOURT, Luiz Cláudio, SANTOS, Antônio da Costa. "Campinas circuniscrição e gênese". $V$ Seminário de História da Cidade e do Urbanismo. PUC - Campinas - São Paulo, out., 1998. . Regularidades do visivel. Tese de doutorado. São Paulo: FAU-USP, 1999.

BORGES, Ana Maria; PALACIN, Luis. Patrimônio histórico de Goiás. Brasília: SPAHAN / proMEMÓRIA, 1987.

BOSCHI, Caio. Os leigos e o poder. São Paulo: Ática, 1986. 
BUENO, Beatriz P. Siqueira. "Iconografia dos engenheiros militares: fonte essencial para o estudo do urbanismo no Brasil setecentista". VSeminário de História da Cidade e do Urbanismo. PUC-Campin - São Paulo, out., 1998.

. "Desenho e designo: O Brasil dos engenheiros militares (1500-1822)". Comunicado apresentado no Congresso ICAM. Rio de Janeiro, maio, 2000.

BURY, John. A arquitetura e a arte no Brasil colonial.(org.) Myrian de Andrade de Oliveira. São Paulo: Nobel, 1991.

CARITA, Rui. "As cidades atlânticas do séc. XVI: fronteiras e modelos estratégicos”. V Seminário de Historia da Cidade e do Urbanismo. PUC - Campinas - S. Paulo, out., 1998.

CASTRO, José Luiz. A organizaşão da igreja católica na capitania de Goiás.(1726-1824). Dissertação .

CHAUL, Nasr Fayad. Caminhos de Goiás: da construção da decadência aos limites da modernidade. Goiânia: UFG, 1997. COELHO, Gustavo Neiva. A formação do espaço urbano do ouro: o caso Vila Boa. Dissertação de
mestrado. Goiânia: UFG, 1997.

CORREIA, José Eduardo Horta.Arquitetura portuguesa, renascimento, maneirismo, estilo chão. Lisboa: Editora Presença, 1991

CORONA, Eduardo e LEMOS, Carlos. Dicionário da arquitetura brasileira. São Paulo: EDART,

COSTA, Lúcio. Lúcio Costa: registro de uma vivência. São Paulo: Empresa das artes, 1995.

DELSON, Roberta Marx. Novas vilas para o Brasil-colônia. Trad. Fernando de Vasconcelos Pinto. Brasília: Ed. Alva-Ciord, 1997.

ETZEL, Eduardo. Arte sacra berço da arte brasileira. São Paulo: Melhoramentos, 1984

. O barroco no Brasil. São Paulo: Melhoramentos, 1984.

FLEXOR, Maria Helena Ochi. "As vilas pombalinas do séc. XVIII: estratégias de povoamento." $V$ Seminário de História da Cidade e do Urbanismo. PUC - Campinas - São Paulo, out.,1998.

FERREZ, Gilberto. O Brasil do primeiro reinado visto pelo botânico William John Burchell. 1825, 1829. Rio de Janeiro: Fundação João Moreira Salles, Fundação Pró-Memória, 1981

FRANCO, Fernando Marías. "Trazas, trazas, trazas: tipos y funciones del dibujo arquitectónico".In (1) Actas del simposio. Camargo, jul., 1992.

FRANÇA, José Augusto. Lisboa pombalina e o iluminismo. Lisboa: Bertrand Editora, 1987.

FONSECA, Cláudia Damasceno. "Funcionários régios, eruditos locais, viajantes estrangeiros: representaçóes da cidade colonial mineira". VSeminário de História da Cidade e do Urbanismo. PUC - Campinas - São Paulo, out., 1998. GOMBRICH, E.H. Ideales e idolos: Ensayos sobre los valores em la bistoria y el arte. Barcelona: Gustavo

HOLANDA, Sérgio Buarque de. História geral da civilização brasileira. 8 ed. Rio de Janeiro: Editora Bertrand do Brasil, 1989.

HOLANDA, Sérgio Buarque de. Do descobrimento à expansão territorial. 8 ed. Rio de Janeiro: Editora
HOORNAET, Eduardo (org.) e outros. História da igreja no Brasil. 4 ed. Petrópolis: Vozes, 1992

Formação do catolicismo brasileiro-1550/1800, 3 ed. Petrópolis: Vozes, 1991.

LEMOS, Carlos A. C. Arquitetura brasileira. São Paulo: Editora da Universidade de São Paulo, 1979 LOTZ, Wolfgang. La arquitectura del renascimento en Itália. Madrid: Herman Blume, 1985.

MARX, Murilo. Nosso chão: do sagrado ao profano. São Paulo: Editora Universidade de São Paulo, 1988.

A cidade brasileira. São Paulo: Melhoramentos / Edusp, 1980.

Paulo, 1991

Cidade no Brasil terra de quem? São Paulo: Nobel Editora/Universidade de São Paulo, São

Cidade no Brasil em que termos? São Paulo: Stúdio/ Nobel, 1999.

MARTINS, Judith. Dicionário de artistas e artífices do séc. XVIII e XIX em Minas Gerais. Rio de Janeiro: IPHAN/MEC, 1974. 1V e 2V.

MATTOS, Raimundo José da Cunha. Chorographia histórica da provincia de Goyaz. Líder: Goiânia, [s/d].

MILHEIRO, Ana Cristina Fernandes Vaz. "Um olhar intruso: o mundo urbano brasileiro narrado através da sensibilidade do estrangeiro". VI Seminário de história da cidade e do urbanismo. Natal, nov. 2000.

MORAES, Cristina de Cássia Pereira. "A capitania dos Goyazes em festa: as comemoraçốs pela convalescência do Rei D. José I em 1760". XXVI simpósio anual do CEHILA/BRASIL. Religiosidades, misticismo e história no Brasil Central. Brasília, set., 1999.

. "O cristianismo na ocupaçáo do Centro Oeste". XXVI simpósio anual do CEHILA/BRASIL. Religiosidades, misticismo e história no Brasil Central. Brasília, set., 1999.

MOREIRA, Rafael. A arquitetura do renascimento no sul de Portugal. A encomenda régia entre moderno e o romano. Tese de doutorado. Lisboa: Universidade Nova de Lisboa, 1991.

"A arte luso-brasileira: modelos, síntese, autonomia”. In: História da expansão. Portugal: Círculo de leitores e autores, 1998

"A arte da arruação e a cidade luso-brasileira (sécs. XVI-XVIII)". V Seminário História da cidade do urbanismo. PUC - Campinas - São Paulo, out., 1998.

MOURA,Carlos. A história da arte em Portugal: o limiar do barroco. Lisboa: Publicaçōes Alfa, 1986. $8 \mathrm{~V}$

KUBLER, George. A arquitetura portuguesa chä: entre as especiarias e os diamantes. Portugal, s/d.

KUHL, Paulo Mugayar. "Crítica à arte e a cultura portuguesa no século XVIII: a visão dos estrangeiros". Simpósio da Associą̧ão Brasileira dos Críticos de Arte. Porto Alegre, nov., 1999.

OLIVEIRA, Myriam de Andrade Ribeiro de. O rococó religioso em Minas Gerais e seus antecedentes europeus. Tese de doutorado. Université Catholique de Louvain, 1990. V 1 e 2.

PADILHA, Nino (org.). Cidade e urbanismo. História, teorias e práticas. Salvador: Mestrado em Arquitetura da FAUFBA, 1998

PAIS DA SILVA, Jorge Henrique. Páginas de história da arte. Lisboa: Editora Stampa, 1986. 2 V. PALACIN, Luis e outros. História de Goiás em documentos: I colônia. Goiânia: Editora da UFG, 1995. 
PEREIRA, José Fernandes. "O barroco do séc. XVIII: Transição e mudança - a história de um conceito estilístico”. In: História da arte portuguesa (org.) Paulo Pereira. Lisboa: Círculo de leitores, 1998. PEREIRA, Paulo. (org.). História da arte portuguesa. Barcelona: Círculo de Leitores, 1995. V. 3

Arquitectura barroca em Portugal. Portugal: Biblioteca Breve, 1992.

"A traça como único princípio". In: Estudos de arte e História. Homenagem a Artur Nobre de Gusmão. Lisboa: Veja, 1995. V. 103.

POHL, Johann Emannuel. Viagem ao interior do Brasil. São Paulo: Edusp/Livraria Itatiaia, 1976. PUPPI, Marcelo. Por uma história não moderna da arquitetura brasileira. Campinas: Pontes, 1998. REIS FILHO, Nestor Goulart. A evolução urbana do Brasil. Contribuição ao estudo da evolução urbano no Brasil (1500-1720). Editora Universidade de São Paulo: São Paulo, 1976.

_. Quadro da arquitetura no Brasil. São Paulo: Perspectiva, 1968. 2000

Imagens de vilas e cidades do Brasil colonial. São Paulo: Editora da Universidade de São Paulo,

SAINT-HILAIRE, August de. Viagens à Provincia de Goiás. São Paulo: Edusp / Editora Itatiaia, 1975. SANTOS, Paulo. Subsidios para o estudo da arquitetura religiosa em Ouro Preto. Rio de Janeiro: Kosmos, 1951.

SILVA, C.J. Trindade da Fonseca. Lugares e pessoas. Subsídios eclesiásticos para a história de Goiás.São Paulo: Escolas Profissionais Salesianas, 1948.

SOLÀ- MORALES, Ignasi. "Prólogo a la edición castelana: Teoría e Historia del Arte en la obra de Alois Riegl."In: RIEGL, Alois. Problemas de estilo. Fundamentos para una historia de la ornamemtación (1893). Trad. De Frederico M. Saller. Barcelona: Editorial Gustavo Gili, 1980.

TEIXEIRA, Manuel C. e Valla, Margarida. O urbanismo português. Lisboa: Livros Horizonte, 1999. TELES, José Mendonça. Vida e obra de Silva e Souza. Coleção documentos. Goiânia: Editora UFG, 1998.

TORRES-LONDOÑO, Fernando. "Paróquia e comunidade na representação do sagrado na colônia". In: Paróquia e comunidade no Brasil. São Paulo: Paulus, 1987.

VALE, Marília M. Brasileiro. Arquitetura religiosa do séc. XIX no antigo sertão de Farinha Podre. Tese de Doutorado. São Paulo: FAU-USP, 1998.

WITTKOWER, Rudolf. La arquitectura en la edade del humanismo. Buenos Aires: Ed. Nueva Visión, 1968.

WOLFFLIN, Heinrich. Conceitos fundamentais da história da arte. Trad. de João Azenha Jr. São Paulo: Martins Fontes, 1984.

REVISTAS

ÁVILA, A. Igrejas e capelas de Sabará. In: Revista Barroco. Belo Horizonte, n. 8.

COELHO, Gustavo Neiva. "Construçóes religiosas no período colonial existentes na região de Vila Boa: 1727/1793.” In: Fragmentos de cultura. IFITEG. Goiânia: UCG, v. 9, n 3, maio/jun, 1999 FLEXOR, Maria Helena Ochi. "Os oficiais mecânicos da Salvador e São Paulo no período colonial”. In Revista Barroco. Belo Horizonte, n. 17., 1993.
MARX, Murilo. "Arraiais mineiros: relendo Sylvio de Vasconcelos." In: Revista Barroco. Belo Horizonte, n. 15., 1992

MIRANDA, Selma Melo."A arquitetura colonial em Minas Gerais: Os planos poligonais." In: Portugah Comissão Nacional para as comemoraçóes dos descobrimentos portugueses. Portugall Brasil-Brasill Portugal. Duas faces de uma realidade artistica. Lisboa, 2000.

MOURA, Carlos Francisco. "Apontamentos para o dicionário de artistas plásticos, artífices e construtores em Mato Grosso nos séc. XVIII e XIX."In: Revista Barroco. Belo Horizonte, n.12, 1992.

NEVES, Sônia Aroeira. "A catedral de salvador. Um estudo sobre a arquitetura maneirista lusobrasileira”. In: Revista Barroco. Belo Horizonte, n. 17, 1993.

OLIVEIRA, Myriam Andrade de. "Plantas poligonais e curvilíneas no barroco brasileiro: Classificação tipológica." In: Revista Barroco. Belo Horizonte, n. 17, 1993. 1994.

REIS FILHO, Nestor Goulart. "Notas sobre o urbanismo barroco no Brasil.": In: Revista barroco. Belo Horizonte, n. 15, 1992.

TELLES, Augusto Carlos da Silva. "Alguns aspectos da arquitetura na segunda metade do século XVIII no Brasil.” In: Revista barroco. Belo Horizonte, n. 7.

"O barroco no Brasil. Análise da bibliografia crítica e colocaşão dos pontos de consenso e dívida." In: Revista do Patrimônio Histórico e Artístico Nacional. Rio de Janeiro, n. 19, 1984 


\section{FONTES DOCUMENTAIS}

I - Arquivo Histórico Ultramarino - AHU (Lisboa)

Manuscritos:

1 - CARTA de D. José I ao provedor das capelas da cidade do Rio de Janeiro exigindo que a partir daquela data todas as Irmandades e Confrarias apresentassem termo de compromisso em 03 de Fevereiro de 1775.

2 - CARTA do (ouvidor geral de Goiás), desembargador Antônio José de Araújo e Sousa, ao rei (D. José), remetendo planta da nova cadeia de Vila Boa, que se encontra quase terminada e informando que nos arraiais de Pilar e Meia Ponte também estão construindo novas cadeias.Dezembro de 1781.

3 - CONSULTA do Conselho Ultramarino, ao rei D. João V, sobre a criação dos bispados de São Paulo e Ribeirão do Carmo, no distrito do Rio de Janeiro, como também as prelazias de Goiás e Cuiabá do mesmo distrito; acerca das côngruas que devem ter os bispos prebendados e capelães; os meios que se apontam para as despesas; os edifícios das catedrais e os lugares que devem ser fundadas.

cx. 3, D. 264

1745, abril, 10, Lisboa.

4 - DOCUMENTO de Lisboa, 10 de abril de 1745.

Recursos para a ereção da matriz.

5 - DOCUMENTO de Lisboa, 24 de novembro de 1750.

6 - DOCUMENTO de Vila Boa, 28 de Maio de 1760.

Códice 250.

Estado da igreja Matriz de Vila Boa de Goiás.

7 - DOCUMENTO do juiz; vereadores e procurador da câmara, enviado ao Rei de Portugal, D. José I, atestando e certificando que não há em Vila Boa de Goiás, irmandade de Misericórdia exercendo as suas funçóes a das Almas.

m Vila Boa e Câmara, maio de 1780. 
8 - DOCUMENTO da Câmara de Vila Boa, 1781

9 - OFÍCIO do Governador e capitáo de Goiás), João Manuel de Melo, ao secretário de estado do governador (da marinha e ultra mar), Francisco Xavier de Mendonça Furtado, sobre o pedido do governador de Mato Grosso (Antônio Rolim de Moura), solicitando o envio de um oficial que tenha ciência militar, para a defesa contra castelhanos e informando ter enviando à capitania de Mato Grosso, o oficial Tomás de Sousa, o qual freqüentou a Academia Militar do Rio de Janeiro 1766 agosto, 23, Vila Boa.

Cx. 22, D.1396

10- OFÍCIO do (governador e capitão de Goiás), João Manuel de Melo, ao sindicante, desembargador Manuel Fonseca Brandão, sobre a preocupação acerca de onde manter os prisioneiros os extesoureiros da fazenda real de Goiás, Guilherme José Pereira, Fernando José leal, Antênio de

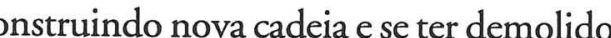
a antiga.

1765, abril, 30, Vila Bo

Cx. 22, D. 1370.

11- OFÍ́CIO do (ouvidor geral de Goiás), desembargador Antônio José de Araújo e Sousa, ao (secretário de estado da marinha e Ultramar, Francisco Xavier de Mendonça Furtado), sobre a conclusão da obra da cadeia de Vila Boa de Goiás; a formação de uma bandeira contra as
hostilidades dos índios Caiapós; a união do (tesoureiro da intendência de Sáo Félix), Diogo de Gouveia Osório e Castro, o vigário da vara e um franciscano residente em São Félix, que se juntaram para a destruição de muitos através de enredos; e solicitando voltar ao Reino. Cx. 22, D. 1384.

Dezembro de 1781, Vila Boa.

12- PARECER do Conselho Ultramarino de 1731. Sobre a nomeaçáo de pessoa para o posto de mestre de campo das Minas de Goiás. Cx. 1, D 2.

13- PATENTE de Joaquim Pereira de Velasco Molina de que é coronel o mesmo Governador; no qual o posto o promoveu Luiz da Cunha Menezes, sendo governador de Goiás, em 1789.

14 - PATENTE de Joaquim Pereira de Velasco Molina e confirmação de seu cargo de mestre de campo e comandante do primeiro regimento de cavalaria auxiliar da Capitania de Goiás, em 1789.

15 - PROVISÓES do governo de D. José I, rei de Portugal, para notificar todas irmandades e confrarias para confirmarem seus compromissos.

16 - PROVISÃO de 1782. Sobre a Irmandade do Glorioso S. Miguel Archanjo e Almas.

17 - PROVISÃO de Confirmação de Compromisso das Irmandades, 1775.

18 - PROVISÃO de 1767. Sobre as Irmandades.

19 - Sobre a inexistência de uma Irmandade de Mizericórdia. 1781

20 - Sobre a Matriz de Santana, 28 de maio de 1760, códice 250.

1.1 - Seção de iconografia:

1.1.1 - Projeto para a Matriz de Traíras.

1.1.2 - Planta Básica de Vila Boa, Goiás, 1782.

1.1.3 - Planta de Vila Boa mostrando o realinhamento, antes de 1782.
II - Arquivo Frei Simão Dorvi - (Cidade de Goiás)

Manuscritos:

1 - ATAS da Câmara de Vila Boa de Goiás, 1741, 1755

2 - AUTO de Demarcação de Vila Boa de Goiás, Lisboa 11 de fevereiro de 1736.

3 - AUTO de Demarcação - Igreja Santa Bárbara, 1775.

4 - AUTO de Arbitramento feito nas obras da igreja da matriz de Vila Boa, sobre a despesa de que necessita, para ficar coberta de telhas, com chaves nas portas, em Vila Boa de Goiás e declaraçáo da despesa para a fatura da capela mor, 1744.

5 - CARTA do Conselho Ultramarino ao governador de São Paulo, notificando o envio da planta da Matriz de Vila Boa de Goiás, em 6 de abril de 1745.

6 - CARTA do governador da capitania de São Paulo à câmara de Vila Boa de Goiás, enviando a planta da igreja da Matriz, 1745.

7 - CARTA da câmara de Vila Boa de Goiás ao governador de São Paulo, notificando que a igreja da matriz já se acha em construçáo conforme o projeto e risco anteriores e que a mesma já se acha em fase adiantada, em 26 de abril de 1745.

8 - CARTA- Registro do Autto (...) e cappitulos de Correyção que deixou nesta Camara no prezente anno de 1745.

9 - CARTA - Registro de uma carta que este senado o Dr. Procurador da Fazenda Real, Sebastiấo Mendes de carvalho, a respeito das sobras dos Caiapós, contribuição que este povo fez e mandou entregar ao tesoureiro da obra das obras da igreja da matriz desta vila, com segunda cópia da entregar ao tesoureiro da obra das
ordem real, em 28 de maio de 1746 .

10 - CARTA de 12 de Janeiro de 1750.

Dar conta do projeto em que se propóe abrir caminho que vem da cidade de São Paulo e Vila de Santos até Vila Boa de Goiás e desta até Cuiabá.

Doc. Avulsos de n. 27 e 29

11 - DOCUMENTO DA CÂMARA de 26 de maio de 1742. Doc. avulso.

12 - DOCUMENTO DA CÂMARA de 30 de março de 1746. Doc. avulso.

13 - LIVRO Y-A, cartório do primeiro ofício, Vila Boa 1792/1799.

Escritura de doaçáo, que faz Francisco do Prado de hum escravo por nome de Manuel Cabrinha à irmandade do Santíssimo Sacramento.

14 - LIVRO- L.P.H. n. ${ }^{\circ}$ 021.Compra de material para obras públicas, 1792.

Compra de materiais e serviços das obras públicas, em Vila Boa de Goiás em 1782/1810.

15 - LIVRO de Compromisso da Irmandade do SS. Sacramento da Matriz da Senhora S.ta Anna da Villa Boa de Goyaz.

16 - LIVRO de Compromisso da Irmandade de Nossa Senhora do Rosário da Cidade de Goyaz. 17 - LIVRO 043.

18 - LIVRO 192, n.042, 1724 a 1762.

19 - LIVRO Letra P, N.015. Sobre a Irmandade Nossa Senhora da Lapa, 1773.

20 - Procuraçáo Rela de D. Maria I para se instalar a Irmandade do Santo Sepulcro em Vila Boa de Goiás, 1790.

n 21 - PROVISÃO de 1778 do Conselho Ultramarino.

m 22 - TERMO DE CORREIÇÃO GERAL - 27 de maio de 1780. Doc. Avulso. 
23 - TERMO DE MEZA de Nossa Senhora do Rosário de 1759. Doc.avulso

24 - TERMO DE VEREANÇA 1780, 1789, 1792, 1793

25 - Sem título. Documento avulso de 1739.

26 - Sem título. Documento avulso de 12 julho de 1752

27 - Sem título. Documentos avulsos, fl. 106, 107.

28 - Sem título. Documento avulso fls 84 V, do V. N. 413

29 - Sem título. Documento sobre Bento José de Souza, 1782.

LISTA DE FIGURAS

30 - Sem título. Documento sobre a Irmandade do Santíssimo Sacramento, 1742

31 - Sem título. Pedido de concessão à câmara para o procedimento de arruaçáo de uma área frente uma igreja, já existente, de Vila Boa de Goiás, em 19 de dezembro de 1739.

III. Arquivo da Torre do Tombo. (Lisboa)

1 - DECRETO N. 463. Catálogo dos decretos do Extinto Conselho de Guerra V. III, 220 B.

IV. Arquivo da Biblioteca Nacional do Rio de Janeiro.

Manuscritos:

1 - Officio N.348. Sobre o Jardim Botânico. Palácio de Queluz em 31 de julho de 1799. D. Rodrigo de Souza Coutinho. Guias de Comunicaçốes, I, 28, 33 .

2 - SOUZA, Silva e. Memória sobre o Descobrimento. Governo, População e Couzas mais notive da Capitania de Goyas. Manuscrito, códice 9-2-10.

3 - Doc. Luís da Cunha Menezes de 16 de outubro de 1768

V. Arquivo da Biblioteca Mário de Andrade (São Paulo).

Acervo de obras raras:

1 - Constituição do Arcebispado da Bahia

2 - XAVIER, Joaquim C. Perspectivas de Vila Boa de Goiás. MSS, d, 26.

3 - ENDER, Thomás. Gravura da Cidade de Goiás. Vila Boa, álbum Atlas de gravuras para viagem de POHL. 13, f. 5.

VI. Arquivo Público do Estado de Goiás

Manuscritos:

1 - Cartas Régias- Patentes Régias 1799-1803, Cx.132

2 - Documentos avulsos da tesouraria Geral de 17714 1755. Cx. 0003.

VII. Arquivo do Cento de Pesquisa Histórica Instituto D. Fernando (Goiânia, UCG).

1 - Sobre o Engenheiro militar Tomás de Souza. Sem catalogação. AU- 59,1396,1617.

2 - Sobre o padre Salvador dos Santos Batista. Sem catalogação. AU-2217. 3 - Sobre as Irmandades. Sem catalogação. AU-370, 823, 824, 858, 1307, 1467, 2030, 2300, 2334,
2381.

VIII. Arquivo do SPHAN - Brasília.

1 - Levantamento arquitetônico.

1. Imagem da antiga Vila Boa de Goia

32

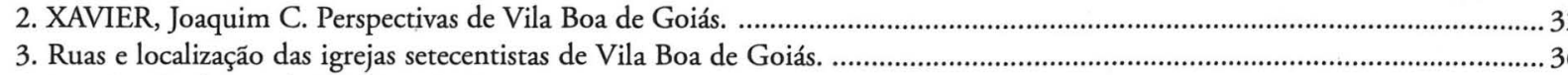

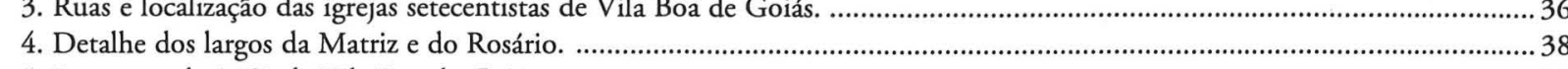

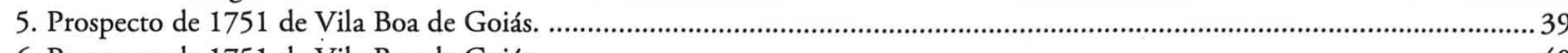

6. Prospecto de 1751 de Vila Boa de Goiás.

7. Prospecto de 1751 de Vila Boa de Goiás.

8. Largo do Chafariz.

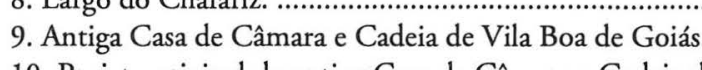

(1)

11. Proposta de realinhamento do tecido urbano de Vila Boa, aproximadamente 1782 ..................................................................47

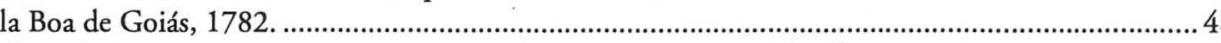

14. Desenhos da antiga Senhora da Boa More.

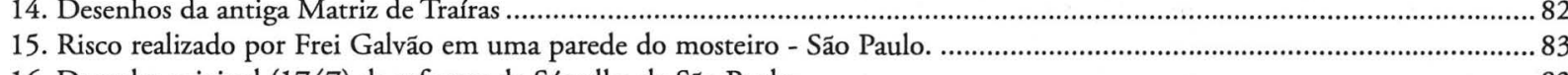

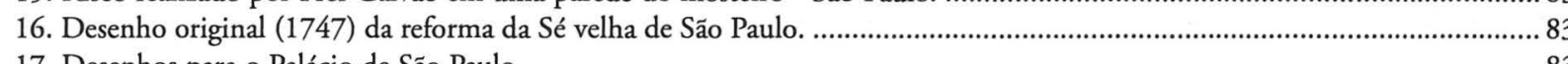

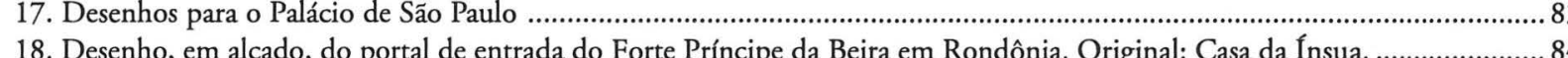

18. Desenho, em alçado, do posenho da Matriz de Santan feito por Willinm John Burchell.

20. Detalhe do frontispício da Irreja Nossa Senhora da Boa Morte.

21. Detalhe na fachada lateral da Igreja Nossa Senhora da Boa Morte. .

23. Igreja Nossa Senhora do Carmo

24. Igreja Nossa Senhora da Abadia.............................

.

25. Altar-mor da lgrya Nossa Ser do

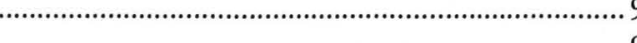

27. Igreja São Francisco de Paul

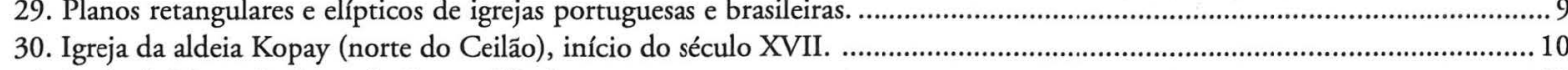

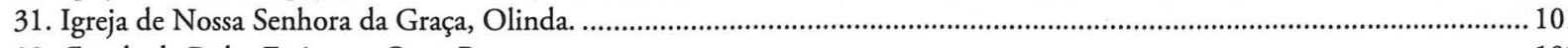

32. Capela de Padre Faria, em Ouro Preto ...........................................................................................110

33. Reconstituiçăo parcial da Matriz de Santana a partiri de um documento do seculo XIX, citado na nota 43 da pág. $45 . . . . . .103$

34. Igreja de Nossa Senhora do Rosário

37. Planta do primeiro e segundo pavimentos da Igreja Nossa Senhora da Abadia . ………………………………………………110

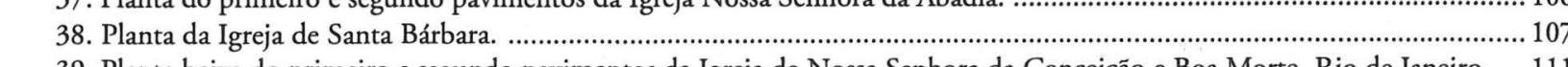

39. Planta baixa do primeiro e segundo pavimentos da Igreja de Nossa Senhora da Conceiçáo e Boa Morte, Rio de Janeiro. .....111

40. Planta baixa do primeiro e segundo pavimentos da Igreja de Nossa Senhora da Lapa dos Mercadores, Ro de Janeiro. ….....112

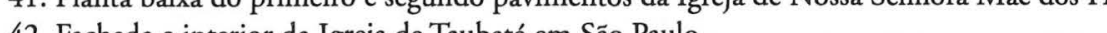

43. Planta esqueḿ́tica da Iroja dordem 3 a da Penitência de São Francisco, São Paulo. ....

44. Planta escuremática da Irejia do Convento da Luzz Săo Paulo.

45. Planta do primeiro e segundo pavimentos da Igreja Nossa Senhora da Boa Morte. ............................................................114

$\tilde{n}$ 46. Cortes lateral e frontal da Igreja Nossa Senhora da Boa Morte .................................................................................115 